$$
\text { UNIVERSIDADE DE SÃO PAULO }
$$

FACULDADE DE FILOSOFIA, LETRAS E CIÊNCIAS HUMANAS DEPARTAMENTO DE LETRAS CLÁSSICAS E VERNÁCULAS PROGRAMA DE FILOLOGIA E LÍNGUA PORTUGUESA

\title{
GÊNEROS DA DIVULGAÇÃO CIENTÍFICA NA INTERNET
}

Flávia Sílvia Machado Ferraz 
UNIVERSIDADE DE SÃO PAULO

FACULDADE DE FILOSOFIA, LETRAS E CIÊNCIAS HUMANAS

DEPARTAMENTO DE LETRAS CLÁSSICAS E VERNÁCULAS

PROGRAMA DE PÓS-GRADUAÇÃO EM FILOLOGIA E LÍNGUA PORTUGUESA

\section{GÊNEROS DA DIVULGAÇÃO CIENTÍFICA NA INTERNET}

Flávia Sílvia Machado Ferraz

Dissertação apresentada ao Programa de Pós-Graduação em Filologia e Língua Portuguesa, do Departamento de Letras Clássicas e Vernáculas da Faculdade de Filosofia, Letras e Ciências Humanas da Universidade de São Paulo, para obtenção do título de Mestre em Letras.

Orientadora: Profa. Dra. Sheila Vieira de Camargo Grillo 


\section{DEDICATÓRIA}

Aos meus inesquecíveis avós,

aos meus amados pais, Pedro e Carmem,

à minha querida Débora,

ao meu companheiro de toda vida Sandro. 


\section{AGRADECIMENTOS}

A Deus e ao Mestre, por tudo.

Á minha orientadora Profa. Dra. Sheila Vieira de Camargo Grillo, por ter confiado no meu trabalho e por ter feito com que eu acreditasse em mim mesma. Agradeço pela paciência, sabedoria e carinho com que conduziu esta orientação.

Aos membros da banca de qualificação e de defesa, Profa. Dra. Roxane Helena Rodrigues Rojo, Prof. Dr. Adail Sobral e Profa. Dra. Maria Lúcia da Cunha Victório de Oliveira Andrade que contribuíram deveras para o aprimoramento deste trabalho, bem como para a minha formação.

À direção da Escola do Futuro, que me apoiou durante todo o processo, em especial à coordenadora da Educação Infantil Paula de Castro Anders. Agradeço também pelo apoio das minhas ‘amigas’ de trabalho.

Aos meus pais, Pedro e Carmem, e à minha irmã Débora, agradeço por vibrarem a cada conquista alcançada e por existirem.

Ao Sandro, por ter me levantado nos momentos mais difíceis e ter se intrometido diversas vezes nesse trabalho.

Aos queridos amigos André, Angélica, Cássio, Ariadne e Gustavo pela paciência, pelos risos e por me apoiarem nessa jornada.

Às minhas amigas de orientação Simone, Solange, Rose, Ariadne e Karina, agradeço pelas observações e pelos momentos que dividimos juntas.

À M. Kolenitenko pelo companheirismo.

Aos meus amigos fraternos de toda hora. 


\section{RESUMO}

O objetivo principal desta pesquisa é analisar gêneros da divulgação científica na internet. Para isso, a pergunta de pesquisa que se coloca é: de que forma o discurso de divulgação científica é constituído na internet, especificamente nos gêneros artigo e reportagem, por meio das relações dialógicas hipertextuais estabelecidas pela utilização dos links eletrônicos. Sob a luz da teoria do círculo de Bakhtin, foram utilizadas como categorias conceituais as noções de interação verbal, enunciado, esfera, dialogismo e gêneros do discurso. Entendendo a DC como parte do complexo processo da esfera da ciência, ao lado de outros tipos de divulgação, tal como o jornalismo científico, no âmbito da linguagem, ela se constitui como prática discursiva que transita entre diferentes esferas, como a científica, jornalística e escolar. Partindo do pressuposto de que a internet configurase como conjunto de esferas, bem como da noção de hipertexto como uma das formas de relações dialógicas estabelecidas entre enunciados por meio dos links eletrônicos, buscou-se verificar o papel destes na constituição dos gêneros digitais artigo e reportagem de divulgação científica. A partir da análise dos diferentes tipos de remissões hipertextuais encontradas, constatou-se que o uso dos links é estabelecido de acordo com as coerções de cada gênero, ao mesmo tempo em que determina diferentes relações semântico-axiológicas por meio da hipertextualidade.

PALAVRAS-CHAVE: Gêneros discursivos, círculo de Bakhtin, divulgação científica, internet e hipertexto digital. 


\begin{abstract}
The main objective of this research was to analyze scientific divulgation genres at the internet. Therefore, the research question was: how is the scientific divulgation speech constituted at the internet, specifically in the genres article and reportage, through the hypertextual dialogical relations established by the use of the electronic links. Based on Bakhtin circle theory, the conceptual categories used were verbal interaction, utterance, dialogism and genres of discourse. Once has the scientific divulgation been understood as a part of the complex process of the science sphere, next to other kinds of divulgation, such as the scientific journalism, in the language area, it is constituted as a discursive practice that moves among different spheres, such as the scientific, journalistic and scholar. Assuming that the internet figures as a conjunct of spheres, as well as the notion of hypertext as one of the dialogical relations established among utterances through the electronic links, their role were verified in the constitution of the scientific divulgation digital genres article and reportage. Through the analysis of the different kinds of hypertextual remissions found, it was observed that the use of links is determined according to each genre, at the same times that stipulates different semantic relations by the hypertextuality.
\end{abstract}

KEY WORDS: Genres of the discourse, Bakhtin Circle, Scientific divulgation, Internet and Digital Hypertext 


\section{SUMÁRIO}

Glossário de termos técnicos e abreviações

$\begin{array}{ll}\text { Introdução } & 1\end{array}$

Capítulo 1. As categorias conceituais do Círculo de Bakhtin 4

1.1 Interação verbal e enunciado $\quad 5$

$\begin{array}{ll}1.2 \text { Dialogismo } & 7\end{array}$

$\begin{array}{ll}1.3 \text { Os gêneros discursivos e seus elementos constitutivos } & 10\end{array}$

$\begin{array}{lr}\text { Capítulo 2. Metodologia } & 16\end{array}$

$\begin{array}{ll}2.1 \text { Constituição do corpus } & 16\end{array}$

2.1.1 Com Ciência: revista eletrônica de divulgação científica 16

2.1.2 Dossiês 18

$\begin{array}{ll}2.1 .3 \text { Artigos e reportagens } & 21\end{array}$

$\begin{array}{ll}2.2 \text { Categorias descritivas } & 24\end{array}$

Capítulo 3. A estrutura da enunciação digital: a internet e o hipertexto 25

$\begin{array}{ll}3.1 \text { Internet } & 27\end{array}$

3.1.1 Surgimento e expansão da rede mundial de computadores 28

3.1.2 Gêneros na internet $\quad 31$

3.2 Hipertexto digital 34

3.2.1 Breve histórico do hipertexto digital 36

3.2.2 Funções do link eletrônico: linearidade e a construção de sentidos 37

3.3 Internet e hipertexto digital: definições do ponto de vista bakhtiniano 41

Capítulo 4. Divulgação científica 44

4.1 Jornalismo científico e divulgação científica 44

$\begin{array}{ll}4.2 \text { Cultura científica } & 46\end{array}$

$\begin{array}{ll}4.3 \mathrm{DC} \text { e a linguagem } & 48\end{array}$

4.3.1 A proposta de Authier-Revuz $\quad 48$

4.3.2 A proposta de Zamboni $\quad 50$

4.3.4 A contribuição do Círculo $\quad 51$ 
Capítulo 5.Artigo e reportagem: gêneros da divulgação científica na internet 54 5.1 O gênero discursivo na Internet: digital ou hipertextual? 54

5.2 Artigo e reportagem digital: um estudo comparativo 56

Capítulo 6. O dialogismo hipertextual pelo link eletrônico 65

6. 1 Relações dialógicas hipertextuais: remissões entre enunciados 65

6.1.1 Remissão entre enunciados internos ao dossiê 66

6.1.2 Remissão a enunciados internos ao site $\quad 69$

$\begin{array}{ll}\text { 6.1.3 Remissão a enunciados externos ao site } & 70\end{array}$

6.2 Análise dos níveis de remissão hipertextual em cada dossiê 72

6.2.1 Energia Nuclear: custos de uma alternativa (2000) 73

6.2.2 Clonagem: a dessacralização da vida (2002) 80

6.2.3 Células-Tronco (2004) 86

$\begin{array}{ll}\text { Considerações finais } & 92\end{array}$

Referências bibliográficas $\quad 96$

Anexo

Cronologia da História da Internet e do Hipertexto Digital

Mapeamento de remissões de links eletrônicos do dossiê Energia Nuclear (2000)

Mapeamento de remissões de links eletrônicos do dossiê Clonagem (2002)

Mapeamento de remissões de links eletrônicos do dossiê Células-tronco (2004)

Corpus 


\section{Glossário de termos técnicos e abreviações}

AD - Análise do discurso.

ARPA (Advanced Research Projects Agency) - organismo de pesquisa norteamericano que desenvolveu, com propósitos militares, uma rede de longa distância, a ARPANET, em conjunto com universidades e centros de pesquisas.

ARPANET (Advanced Research Projects Agency Network) - rede de longa distância criada em 1969 pela Advanced Research Projects Agency em consórcio com as principais universidades e centros de pesquisa dos Estados Unidos. É conhecida como a rede-mãe da internet de hoje e foi colocada fora de operação em 1990.

Backbone - espinha dorsal de uma rede, uma estrutura composta de linhas de conexão de alta velocidade, que, por sua vez, se conecta a linhas de menor velocidade em várias sub-redes.

Blog - forma abreviada de weblog. Uma espécie de diário virtual via internet, denominação composta dos termos ingleses $w e b=$ teia e $\log =$ relatório ou registro.

Chat - em português, também conhecido como bate-papo. Programa de software interligado em rede que permite que diversos usuários realizem conversações em tempo real entre si, digitando mensagens em seus respectivos computadores e enviando-os por meio de uma rede local ou da internet.

DC - Divulgação científica

E-commerce - electronic commerce, em português, comércio eletrônico que passou a existir a partir da década de 90. 
Hiperlink - conexão que interliga os computadores da rede.

Internet - Com inicial maiúscula, significa a "rede das redes”, originalmente criada nos Estados Unidos, que se tornou uma associação mundial de redes interligadas em mais de 70 países. Os meios de ligação dos computadores desta rede são variados: rádio, linhas telefônicas, linhas digitais, satélite, fibras óticas, etc. Com inicial minúscula, significa genericamente uma coleção de redes locais e / ou de longa distância.

Java - linguagem orientada a objeto de programação muito similar ao C++ ou C, destinada à criação de desenhos, textos e pinturas animadas e / ou interativas.

JC - Jornalismo científico.

NSF (National Science Foundation) - órgão do governo norte-americano que promove a ciência e a pesquisa; fundador da NSFnet, rede para ligação das universidades à internet.

Orkut - é uma comunidade virtual afiliada ao Google, criada em 22 de Janeiro de 2004. Seu nome é originado no projetista chefe, Orkut Büyükkokten, engenheiro do Google. Sistemas como este adotado pelo projetista também são chamados de rede social.

PC - Personal Computer. Criados pela IBM, os computadores pessoais passaram a ser difundidos em 1981.

RNP (Rede Nacional de Pesquisa) - é uma autarquia ligada ao Ministério de Ciência e Tecnologia do governo federal do Brasil, responsável pela rede acadêmica do Brasil. Atualmente o trabalho da RNP é dividido em cada estado da federação em pontos de presença, sendo ao total 26 pontos. Além disso, a RNP possui dois centros de operações, um em Campinas e o outro no Rio de Janeiro, núcleo da rede. 
Site - um sítio, mais conhecido pelo equivalente inglês site, é uma coleção de páginas web, isto é, de documentos acessíveis através da world wide web, na Internet.

Web - o mesmo que World Web Wide.

World Wide Web - teia de alcance mundial. Serviço que oferece acesso, por meio de hiperlinks, a um espaço multimídia da internet. Responsável pela popularização da rede, a WWW possibilita uma navegação mais fácil pela internet. 


\section{Introdução}

Tudo se reduz ao diálogo, à contraposição dialógica enquanto centro.

Tudo é meio, o diálogo é o fim. Uma só voz nada termina, nada resolve. Duas vozes são o mínimo de vida.

(Mikhail Bakhtin)

Esta pesquisa apóia-se nas noções de gêneros discursivos e dialogismo do Círculo de Bakhtin para buscar compreender como é estabelecido o discurso de divulgação científica na internet. Considerando que a comunicação verbal se dá por meio de gêneros discursivos presentes em diferentes esferas da atividade humana e que a tecnologia é um fator de considerável influência sobre sua constituição da linguagem, este trabalho visa refletir de que forma o discurso de divulgação científica é constituído na Internet, especificamente nos gêneros artigo e reportagem, por meio das relações dialógicas hipertextuais estabelecidas pela utilização dos links eletrônicos.

Sendo parte de um projeto maior ${ }^{1}$ que visa ao estudo da divulgação científica como forma de transmissão de saberes na esfera midiática, considerou-se, nesta dissertação, que um corpus retirado da internet traria uma nova perspectiva frente às categorias conceituais e descritivas contempladas pelo grupo de pesquisa. A relevância da pesquisa e a escolha do tema no qual se apóia justificam-se por algumas razões aqui apresentadas. A primeira delas diz respeito à necessidade de se refletir sobre a especificidade da divulgação científica enquanto prática discursiva.

As demais questões estão ligadas à internet. Trata-se de um espaço de comunicação extremamente recente (com uso comercial a partir de 1995) e de maior difusão entre a população mundial, algo jamais experimentado pelo homem na História dos meios de comunicação e que, sem dúvidas, tem modificado certos usos da linguagem.

A escassez de trabalhos na área dos estudos lingüísticos e discursivos que vêm se debruçando sobre a constituição da linguagem na internet, perante a evolução

\footnotetext{
${ }^{1}$ Esta dissertação integra-se ao projeto "O funcionamento de formas do português em gêneros de transmissão de saberes", coordenado pela Profa. Dra. Sheila Vieira de Camargo Grillo. O foco principal do projeto é a descrição e a interpretação de procedimentos discursivos de transmissão de saberes científicos ao público de não-especialistas, presentes em diferentes gêneros e esferas.
} 
rápida desta tecnologia, pode ser considerada um terceiro fator que motivou esta pesquisa. Muitas abordagens sobre a internet e o hipertexto digital não propõem um posicionamento claro e uma reflexão mais aprofundada, sobretudo a respeito de aspectos terminológicos e conceituais. Dessa forma, não se procurará estabelecer um caminho único e inflexível para a reflexão de seus dados, mas sim, buscar-se-á um posicionamento perante a leitura feita sobre os trabalhos dirigidos à questão da internet e da divulgação científica sob forma de diálogo.

A partir disso, a pergunta de pesquisa que se coloca é a seguinte: de que forma a DC é constituída nos gêneros digitais artigo e reportagem por meio das relações dialógicas estabelecidas pelos links eletrônicos?

Sendo assim, os objetivos específicos do trabalho são: (i) verificar as relações dialógicas hipertextuais instauradas por meio dos links eletrônicos nos gêneros artigo e reportagem e (ii) elencar os diferentes tipos de remissão hipertextual encontradas, bem como estabelecer suas funções.

O primeiro capítulo da pesquisa abordará as categorias conceituais do Círculo de Bakhtin que servirão de base para a análise do corpus. As categorias selecionadas foram: interação verbal e enunciado; dialogismo e gêneros discursivos. A noção de esfera também permeará as discussões envolvendo a divulgação científica e a internet.

O segundo capítulo, que trata da metodologia do trabalho, abordará a escolha e descrição do corpus e da categoria descritiva selecionada: os links eletrônicos e as relações dialógicas que estabelecem. Para tanto, o corpus do trabalho foi retirado de uma revista eletrônica de divulgação científica chamada Com Ciência. Tal revista foi escolhida, porque, além de possuir credibilidade no mundo acadêmico e ser fruto do curso de pós-graduação em jornalismo científico oferecido pelo LabJor da UNICAMP, existe somente na internet, ou seja, não há versão impressa da revista. O corpus foi recortado diacronicamente pelos anos de 2000, 2002 e 2004, a fim de se observar aspectos relevantes da evolução da linguagem na internet. Foram escolhidas reportagens especiais, também conhecidas como dossiês, formadas por uma compilação de textos pertencentes a gêneros diferentes (dentre eles artigos e reportagens) que contemplam os seguintes temas: energia nuclear, clonagem humana e células-tronco.

O terceiro capítulo abordará a questão da internet e do hipertexto. Será traçada uma perspectiva histórica sobre a internet e o aparecimento da noção de hipertexto, 
bem como uma reflexão sobre a terminologia e conceitos que vêm sendo adotados pelos estudos lingǘsticos e discursivos voltados a este assunto. A utilização dos links eletrônicos e a construção de sentido no hipertexto digital também serão abordadas.

O quarto capítulo dedicar-se-á às questões voltadas à divulgação cientifica (DC), momento em que será proposta uma discussão sobre a definição da DC em relação às noções de jornalismo científico e cultura científica. Em seguida, serão analisadas as propostas de Authier-Revuz, Zamboni e demais autores da análise do discurso, bem como a contribuição da teoria do círculo para a questão. Finalmente, haverá uma reflexão a respeito da constituição da DC na Internet.

No quinto capítulo, serão analisados elementos dos gêneros discursivos artigo e reportagem na internet. Essa parte da análise tratará da questão dos gêneros discursivos, mais uma vez segundo a teoria do círculo de Bakhtin. Uma vez que os gêneros escolhidos, artigo e reportagem de divulgação científica, ocorrem em documentos impressos, será proposta uma reflexão sobre o estatuto desses gêneros frente a esta nova tecnologia. Em seguida, faremos uma análise comparativa dos gêneros escolhidos quanto ao emprego do link eletrônico de forma quantitativa e diacrônica.

O capítulo seis considerará, por um lado, os elementos que constituem e caracterizam o discurso de divulgação científica e, por outro, as características do hipertexto digital. Será utilizada a noção de dialogismo do círculo bakhtiniano para darmos conta das relações dialógicas entre enunciados. Essas relações são instauradas por meio da dinâmica de remissão a outros enunciados, realizada pelos links eletrônicos.

O trabalho traz ainda uma cronologia referente à História da internet, bem como um glossário de termos técnicos para a melhor compreensão dos aspectos tecnológicos que serão abordados e o mapeamento das remissões de links eletrônicos em cada dossiê escolhido para análise. 


\section{Capítulo 1}

\section{As categorias conceituais do Círculo de Bakhtin}

A teoria bakhtiniana constitui-se, sobretudo, como uma teoria dialógica da linguagem. Assim, como define Brait (2006a), “o conjunto das obras do Círculo [de Bakhtin] motivou o nascimento de uma análise / teoria dialógica do discurso” (p. 910). A própria questão da autoria das obras do Círculo de Bakhtin reflete este modo de conceber a linguagem, uma vez que as categorias conceituais ali forjadas foram fruto da discussão e do pensamento de vários estudiosos, tais como o próprio Bakhtin, Volochinov e Medvedev, e de suas obras. Sobral (2005) chega a utilizar a expressão Círculo Dialógico para se referir ao grupo de pensadores.

Aprofundando-se na idéia de que a linguagem é constituída pelo diálogo entre diferentes discursos de temporalidade e espaços diversos, a própria teoria bakhtiniana pode ser considerada uma réplica na discussão sobre os estudos da linguagem desde a Antigüidade, sobretudo no que diz respeito aos gêneros, cujo estudo inicia-se em Aristóteles e passa pelos estudos literários e retóricos, sendo reelaborados por Bakhtin.

Assim, tanto o pensamento de uma época, quanto as obras que ele produz, "vivem num grande tempo porque são capazes de romper os limites do presente onde surgem” (Machado: 2005, p.159). A autora acrescenta que as grandes obras não só se deslocam do passado até os dias de hoje, mas também, se projetam para o futuro. Isto ocorre com as obras do Círculo, que nos possibilitam utilizar suas categorias conceituais para falar de inovações não experimentadas ou vivenciadas por seus autores em sua época, como é o caso da popularização do uso do computador, novo veículo tecnológico para os gêneros discursivos.

Logo, recorrer-se-à aos conceitos centrais do Círculo de Bakhtin para analisar o discurso de divulgação científica (doravante DDC) constituído no suporte computacional, mais precisamente, em seu complexo espaço de comunicação ${ }^{2}$, a internet. Para tanto, este capítulo visa refletir a respeito dos seguintes conceitos da teoria do Círculo de Bakhtin: (i) interação verbal e enunciado; (ii) dialogismo e (iii) gêneros discursivos e seus elementos constitutivos.

\footnotetext{
${ }^{2}$ Definição proposta por Levy (1999, p. 11).
} 


\subsection{Interação verbal e enunciado}

Fundamentalmente, a teoria bakhtiniana concebe a língua em sua natureza social e histórica, caracterizada por seus aspectos discursivos e enunciativos. Assim, a língua é compreendida não somente por suas peculiaridades formais e estruturais, mas principalmente, como atividade social, histórica e cognitiva.

Bakhtin diz que "a verdadeira substância da língua é constituída pelo fenômeno social da interação verbal, realizada através da enunciação ou das enunciações. A interação verbal constitui a realidade fundamental da língua” (Bakhtin/Volochinov: 1929/2004, p.123). Grillo (2006a) diz que a interação verbal é o “espaço de constituição e existência da língua” (p.137).

Assim, é por meio do enunciado, "unidade real da comunicação verbal" (Bakhtin: 1977/1979, 293), que a interação entre os sujeitos no processo comunicativo é estruturada e, logo, o enunciado também pode ser considerado a 'realidade fundamental da língua'. Toda comunicação verbal ocorre mediante a alternância dos enunciados, utilizados por seus sujeitos falantes no âmbito da realidade extraverbal.

Segundo Brait \& Melo (2005),

O enunciado e as particularidades de sua enunciação configuram,
necessariamente, o processo interativo, ou seja, o verbal e o não verbal que
integram a situação e, ao mesmo tempo, fazem parte de um contexto maior
histórico, tanto no que diz respeito a aspectos que antecedem esse enunciado
específico quanto ao que ele projeta adiante. (p. 67)

Desde as suas primeiras obras até aquelas que foram publicadas postumamente, a noção de enunciado permeia a obra do Círculo. Em The formal method in literary scholarship de 1928, o enunciado é entendido como elemento crucial para a consciência e compreensão da realidade em contraposição às formas lingüísticas. Embora tais formas lingüísticas sejam indispensáveis para a 'refração da consciência da realidade’, é no nível do enunciado que ocorre a comunicação verbal entre os sujeitos falantes.

Na obra póstuma Estética da criação verbal (1952-53/1979/2003), há dois textos que contemplam a noção de enunciado de forma mais detalhada. Em Os gêneros do discurso (1952-53/2003), o enunciado é designado como unidade da comunicação discursiva em contraposição às unidades da língua (palavras e orações). Bakhtin chama a atenção para a diferença entre essas unidades (as do discurso e as da 
língua) quando afirma que o enunciado é de natureza ativamente responsiva. Trata-se de um "elo na corrente complexamente organizada de outros enunciados" (Bakhtin: 1952-53/2003) que responde a enunciados anteriores e que suscita a resposta de enunciados futuros.

Enquanto unidade discursiva da comunicação verbal ${ }^{3}$, o enunciado é tomado pelo tema, fenômeno responsável pela apreensão comunicativa de aspectos da realidade, e se torna uma unidade que transcende o nível lingüístico em sua materialidade. Contrariamente, uma oração ou palavra podem conter significado, mesmo que isoladas do todo do enunciado, mas não apresentam sentido fora de um contexto de fala. Logo, como ocorre com o enunciado, a oração não se relaciona com o contexto extraverbal da realidade. Brait \& Melo (2005: 63) apontam para o caráter extraverbal do enunciado dizendo que este "é concebido como unidade de comunicação necessariamente contextualizada”.

Ainda em Os gêneros do discurso (1952-53/2003), há a discussão acerca do limite do enunciado. Sendo elo na cadeia da comunicação verbal, como se pode definir um enunciado reconhecendo seu início e seu fim? "Os limites de cada enunciado concreto como unidade da comunicação discursiva são definidos pela alternância dos sujeitos do discurso, ou seja, pela alternância dos falantes” (Bakhtin: 1952-53/2003, p. 275). Todo enunciado possui princípio e fim determinados pela ação de diferentes sujeitos falantes. A alternância dos sujeitos é o primeiro aspecto do enunciado apontado por Bakhtin neste texto. Os outros aspectos que serão levantados tratam da conclusibilidade do enunciado e dos gêneros discursivos como forma estável dos enunciados.

A conclusibilidade que pode ser considerada um aspecto interno da alternância dos sujeitos discursivos e está relacionada ao caráter responsivo do enunciado. "O primeiro e mais importante critério de conclusibilidade do enunciado é a possibilidade de responder a ele [...] de ocupar em relação a ele uma posição responsiva” (Bakhtin: 1952-53/2003, p. 281).

Em outro ensaio da mesma obra, $O$ problema do texto na lingüística, na filologia e em outras ciências humanas (1977/2003), Bakhtin continua a discorrer sobre o enunciado. Como dito anteriormente, para Bakhtin, o enunciado é a unidade

\footnotetext{
${ }^{3}$ Nesta pesquisa considerar-se-á equivalentes as noções de unidade discursiva e unidade enunciativa.
} 
real da comunicação verbal. “A fala só existe, na realidade, na forma concreta dos enunciados de um indivíduo: do sujeito de um discurso-fala” (p.293).

Neste ensaio, repetidamente, o autor utiliza a palavra 'texto' para referir-se a enunciado. “O texto como enunciado” (Bakhtin: 1977/2003, p.308). Isto também se faz claro em outros momentos do ensaio: "O texto como enunciado incluído na comunicação discursiva de dado campo. O texto como mônada original, que reflete todos os textos (no limite) de um dado campo do sentido.” (Bakhtin: 1977/2003, p.309). O texto, neste caso enquanto enunciado, instaura-se na comunicação discursiva e apresenta potencial dialógico como se pode ver no seguinte trecho: "as relações dialógicas entre os textos e no interior de um texto” (p. 309).

Faz-se necessário ressaltar que a sinonímia entre as expressões 'texto' e 'enunciado', neste ensaio, coexiste com a noção de texto enquanto unidade lingüística. Anteriormente, em Problemas da poética de Dostoiéviski (1929), Bakhtin refere-se a esta segunda concepção de texto: "Qualquer confronto puramente lingüístico ou grupamento de quaisquer textos abstrai forçosamente todas as relações dialógicas entre eles enquanto enunciados integrais” (p.182).

A partir da definição de enunciado e suas características principais de acordo com o que foi apresentado pela teoria do Círculo, serão destacadas outras duas importantes categorias conceituais da obra Bakhtiniana: o dialogismo e os gêneros do discurso. Ambos os conceitos estão relacionados à noção de enunciado que foi explorada até agora.

\subsection{Dialogismo}

Retomando a questão do enunciado, pode-se defini-lo como um elo na cadeia de comunicação verbal que espera uma compreensão responsiva por parte de outros enunciados, ao retomar enunciados passados e ao antecipar, de forma ativamente responsiva, aqueles que serão suscitados no contexto discursivo. Isto se deve à potencialidade dialógica do enunciado. Grillo (2003: 44) afirma que “o caráter dialógico do enunciado define que ele é, ao mesmo tempo, resposta aos enunciados que o precedem e que ele espera uma resposta de seu alocutário”.

Acrescentando, Bakhtin afirma que o enunciado faz parte de um mundo de relações inteiramente dialógicas e não apenas constitui-se como um nível superior ao 
da sintaxe como "unidade do nível último e superior ou andar da estrutura da língua” (Bakhtin: 1952-53/2003, p. 332)

A interação verbal é constituída pelo percurso sócio-histórico dos enunciados e configura-se assim dialogicamente, indo além do diálogo face a face, uma vez que “o diálogo, no sentido estrito do termo, não constitui, é claro, senão uma das formas, é verdade que das mais importantes, da interação verbal” (Bakhtin/Volochinov: 1929/2004, 123). Ou seja, conforme diz o texto em Marxismo e filosofia da linguagem, o caráter dialógico da língua, presente no processo de interação verbal, está contido na "essência” de cada enunciado.

Assim como a produção, a compreensão de um enunciado, afirma Barros (2003: 25), “é sempre dialógica, pois implica a participação de um terceiro que acaba penetrando o enunciado na medida em que a compreensão é um momento constitutivo do enunciado, do sistema dialógico exigido por ele”.

Ainda em Marxismo e filosofia da linguagem, Bakhtin (1929/2004) fala sobre a natureza dialógica do enunciado.

Toda enunciação, mesmo na forma imobilizada da escrita, é uma resposta a alguma coisa e é construída como tal. Não passa de um elo na cadeia dos atos de fala. Toda inscrição prolonga aquelas que a precederam, trava uma polêmica com elas, conta as reações ativas da compreensão, antecipa-as. (Bakhtin: 1929 / 2004, p. 98)

A noção de dialogismo representa a base de sustentação para todos os desdobramentos da teoria bakhtiniana, sendo concebida como "princípio constitutivo da linguagem e a condição do sentido do discurso” (Barros, 2003:2). Todas as categorias conceituais formuladas no âmbito da teoria do Círculo bakhtiniano, tais como enunciado, processo enunciativo, gêneros discursivos, entre outros, convergem para esta concepção dialógica da linguagem.

Tamanha é a centralidade da questão do dialogismo para a teoria do Círculo, que Bakhtin chegou a elaborar a idéia de uma disciplina chamada Metalingüística, - que Todorov optou pelo termo francês “Translinguistique” para não confundir com a noção de metalinguagem -, a fim de dar conta do exame das relações dialógicas entre os enunciados e sua constituição real.

Em O discurso em Dostoiéviski, capítulo final do livro Problemas da poética de Dostoiéviski (1963/2003), Bakhtin nos explica o objeto da metalingüística dizendo que 
“as relações dialógicas (inclusive as relações dialógicas do falante com sua própria fala) são objeto da metalingüística” (p.182). Pode-se considerar que a metalingüística proposta pelo Círculo tinha como objetivo debruçar-se, mais precisamente, sobre as relações dialógicas do discurso. Neste mesmo texto, Bakhtin diz que a metalingüística, assim como a lingüística, estuda o discurso como fenômeno concreto, complexo e multifacetado. No entanto, essas duas disciplinas "devem complementar-se mutuamente e não fundir-se.”, diz Bakhtin (1929/1993, p. 181).

Nesta mesma obra, Bakhtin ressalta que as relações dialógicas são extralingüísticas ao mesmo tempo em não podem ser separadas da concretude da língua. “Toda a vida da linguagem, seja qual for o seu campo de emprego (a linguagem cotidiana, a prática, a científica, a artística, etc.) está impregnada de relações dialógicas.” (p.183). Ou seja, as relações dialógicas são impossíveis sem relações lógicas e concreto-semânticas, mas são irredutíveis a estas e têm especificidade própria.

Mais adiante, em $O$ problema do texto na lingüística, na filologia e em outras ciências humanas (Bakhtin, 1977/ 2003) o autor ressalta o lugar da língua no processo dialógico ao dizer que “do ponto de vista dos objetivos extralingüísticos do enunciado todo, o lingüístico é apenas um meio” (p.313).

O dialogismo configura-se como um conceito amplo que, num primeiro momento, pode ser entendido como a relação entre "enunciados integrais de diferentes sujeitos do discurso” (Os gêneros do discurso, Bakhtin, 1952-53/2003: 323) pertencentes a um mesmo plano de sentido. Segundo Bakhtin,

As relações dialógicas são relações (semânticas) entre toda espécie de enunciados na comunicação discursiva. Dois enunciados, quaisquer que sejam, se confrontados em um plano de sentido (não como objetos e não como exemplos lingüísticos), acabam em relação dialógica. (1977 / 2003, p. 323)

O aspecto dialógico está instaurado não somente na relação da língua com as coisas do mundo, ou somente na relação entre os seus interlocutores, mas também, na relação discursiva entre os enunciados. Isto é possível pelo fato de o enunciado ser dotado de um todo de sentido que lhe foi conferido sócio-historicamente, além do aparato lingüístico-textual que o sustenta. Por isso, as relações dialógicas são relações semânticas. 
Outro fator relevante diz respeito ao fato de as relações dialógicas não ocorrerem somente em enunciações integrais. Qualquer fragmento do significante de um enunciado pode estabelecer este tipo de relação, “inclusive no íntimo de uma palavra isolada se nela se chocam dialogicamente duas vozes” (Bakhtin: 1975/1993, p.184). O dialogismo, logicamente, também está presente em diferentes estilos de linguagem ou dialetos sociais.

Nas obras do Círculo de Bakhtin, vê-se que o dialogismo se constitui de diversas maneiras. De modalidades do diálogo cotidiano a enunciados impressos (tal como um livro que pode ser comentado, resenhado ou transformado em objeto de estudo científico), as relações dialógicas podem ser estabelecidas por meio de qualquer forma de interação verbal. Entretanto, "não deve ser confundido com a interação face a face” (Fiorin: 2006, 166), pois trata-se da própria forma de funcionamento da linguagem, seja qual for o gênero discursivo, "suscitando uma compreensão responsiva ativa nos enunciados futuros dos interlocutores” (Fiorin: 2006, 166), a fim de responder a enunciados precedentes.

Para finalizar, pode-se considerar que todo o processo de enunciação é dialógico, pois retoma elementos que já foram concretizados anteriormente e 'prepara o terreno’ aos novos enunciados concretos que cada nova situação sócio-histórica fará emergir na língua. Ou seja, “cada enunciação, cada ato de criação individual é único e não reiterável, mas em cada enunciação encontram-se elementos idênticos aos de outras enunciações no seio de um determinado grupo de locutores” (Bakhtin/Volochinov: 1929/ 2004, p.77).

\subsection{Os gêneros discursivos e seus elementos constitutivos}

A comunicação verbal somente se realiza por meio da produção de enunciados concretos que fazem parte de alguma "esfera da comunicação discursiva” (Bakhtin, 1963/2003, p. 279). De acordo com Grillo (2006a), as esferas

dão conta da realidade plural da atividade humana ao mesmo tempo que se assentam sobre um terreno comum da linguagem. Essa diversidade é condicionadora do modo de apreensão e transmissão do discurso alheio, bem como da caracterização dos enunciados e de seus gêneros. (Grillo: 2006, p.147) 
Em cada esfera da atividade humana, surgem enunciados que refletem "as condições específicas e as finalidades de cada uma dessas esferas” (Bakhtin, 195253/2003: 279). As diferentes esferas comportam os gêneros discursivos, sem os quais a comunicação verbal não pode ser estabelecida. “Cada esfera social cria seus tipos relativamente estáveis de enunciado” (Bakhtin, 1952-53/2003: 279).

Todo enunciado, em sua modalidade escrita ou oral, obedece às coerções do gênero discursivo e, conseqüentemente, da esfera de que faz parte. O enunciado em suas diferentes formas [relativamente] estáveis e típicas, ao contrário das formas da língua - em sua estabilidade, coerção e normatividade - estabelece diferentes gêneros do discurso.

A fim de que as condições e as finalidades suscitadas por cada esfera sejam concretizadas, os enunciados, ou melhor, os tipos relativamente estáveis de enunciados, obedecem à recorrência de três fatores estruturais básicos que compõem os gêneros discursivos: o estilo, o conteúdo temático e a forma composicional. Assim, os enunciados, por meio dos gêneros discursivos, correspondem à concretização da língua em diferentes situações sociais mediante ao processo de interação verbal.

Em seus estudos iniciais sobre a questão do gênero, na obra The formal method in literary scholarship, Bakhtin / Medevdev (1928/1991) afirmam que os gêneros possuem capacidade de definir diferentes aspectos da realidade. Ou seja, cada gênero possui a capacidade de definir seus princípios de seleção, formas de ver e conceitualizar a realidade.

Segundo Bakhtin / Medevdev (1928/1991, p. 134) “(...) human consciousness possesses a series of inner genres for seeing and conceptualizing reality. A given consciousness is richer or poorer in genres, depending on its ideological environment ${ }^{4 »}$. Isto é, a consciência humana vale-se dos gêneros para lidar com a realidade.

A variedade dos gêneros discursivos é imensa, indo “das esferas impublicáveis do discurso interior às obras de arte e aos tratados científicos” (O problema do texto na lingüística, na filologia e em outras ciências humanas, Bakhtin: 1977/2003, p.324). Em seu texto dedicado à questão dos gêneros, Bakhtin define os seus elementos constitutivos:

\footnotetext{
4 “... a consciência humana possui uma série de gêneros internos par a ver e conceitualizar a realidade. Uma dada consciência é mais rica ou mais pobre em gêneros, dependendo de seu ambiente ideológico.”
} 
(...) todos esses três elementos - o conteúdo temático, o estilo, a construção composicional - estão indissoluvelmente ligados no todo do enunciado e são igualmente determinados pela especificidade de um determinado campo da comunicação. Evidentemente, cada enunciado particular é individual, mas cada campo de utilização da língua elabora seus tipos relativamente estáveis de enunciado, os quais denominamos gêneros do discurso. (Bakhtin: 1952-53 / 2003, p.261).

Os três elementos que constituem os gêneros discursivos - conteúdo temático, estilo e forma / construção composicional - são complementares entre si e apresentam especificidades provenientes de cada esfera em que estão inseridos. Esses fatores conferem aos enunciados o seu caráter estável.

Em The formal method in literary scholarship, Bakhtin / Medevdev (1928/1991) não se esgota ao método formalista ao dizer que o tema (ou conteúdo temático) não corresponde ao significado das formas lingüísticas. O tema do enunciado não corresponde somente à materialidade da língua. Faz uso das unidades lingüísticas, não pode ser separado de uma situação social e historicamente estabelecida. Nas palavras dos autores, “Theme always trancends language” (Bakhtin/Medevdev, 1928/1991: p.132). Nesta obra, também fica claro que o conteúdo temático é um dos componentes do gênero que não deve ser confundido com o assunto ou objeto de discussão do discurso.

O tema é a realidade básica do enunciado, sendo que "it is the whole utterance and its forms, which cannot be reduced to any linguistic forms, which control the theme.(...) Consequently, it is inseparable from the total situation of the utterance to the same extent that it is inseparable from the linguistic elements" (Bakhtin / Medevdev: 1928/1991, p.132).

Em Marxismo e Filosofia da Linguagem, Bakhtin/Volochinov (1929/2004) continuam a elaborar a distinção entre significação e tema, sendo que o último é definido como "um sentido definido e único, uma significação unitária, é uma propriedade que pertence a cada enunciação como um todo” (Bakhtin/Volochinov, 1229/2004: p.128). Em contrapartida, a significação pode ser entendida como aquilo que pode ser repetido e é reiterável, como se pode depreender do seguinte fragmento de Bakhtin/Volochinov (1929/2004):

\footnotetext{
5 “É o todo do enunciado e suas formas, que não podem ser reduzidas a nenhuma forma lingüística, que controlam o tema. (...) Conseqüentemente, é inseparável da situação total do enunciado enquanto é inseparável dos elementos lingüísticos”.
} 
O tema é um sistema de signos dinâmico e complexo, que procura adaptar-se adequadamente às condições de um dado momento da evolução. O tema é uma reação da consciência em devir ao ser em devir. A significação é um aparato técnico para a realização do tema. (p.129)

Segundo Cereja (2005:202), “o tema se incorpora à significação, de modo que o sistema é sempre flexível, mutável, renovável”, o que reforça sua complementaridade. Diferentemente da significação, que diz respeito aos elementos reiteráveis e estáveis do sistema da língua, o tema refere-se ao caráter concreto e é determinado sóciohistoricamente. Enquanto a significação é relativamente estável nas instâncias históricas em que é utilizada e refere-se ao signo lingüístico, o tema é indissociável de sua historicidade e refere-se ao signo ideológico. No entanto, é importante ressaltar que Bakhtin aponta que significação e tema são aspectos complementares, sendo sua distinção didaticamente necessária.

O tema atua nos enunciados a fim de relacioná-los a diferentes contextos, representando as diferentes formas de se ver e conceituar a realidade. O enunciado vale-se tanto das formas lingüísticas quanto dos elementos extra-verbais da situação de comunicação. O tema relaciona o enunciado a diferentes contextos e representa as diferentes formas de se ver e conceituar a realidade.

Grillo (2006b) complementa esta explicação ao afirmar que o tema de um enunciado

refere-se ao modo de relação do enunciado com o objeto do sentido; é de natureza semântica; caracteriza-se por atribuir uma apreensão delimitadora do objeto do sentido e por compor-se de uma expressão valorativa, uma vez que não há neutralidade no domínio do enunciado (p. 146).

Conforme supracitado, o tema na instância do enunciado trabalha no plano da refração da realidade. Sendo aspecto constitutivo do enunciado, pode-se aplicar a noção de tema aos tipos estáveis de enunciados, os gêneros do discurso. O tema do enunciado é uma representação das possibilidades de preenchimento do conteúdo temático do gênero discursivo.

O conteúdo temático pode ser considerado como a própria forma de apreensão da realidade por meio dos gêneros discursivos. Participam de sua construção tanto elementos estáveis da significação quanto elementos extraverbais que integram a situação de produção, recepção e circulação. 
O segundo componente dos gêneros do discurso a ser discutido é o estilo. Este refere-se à individualidade de expressão de cada autor ou dos diferentes tipos de enunciados, por meio da seleção dos recursos lexicais e sintáticos de um sistema lingüístico. Segundo Bakhtin, em Estética da criação verbal (1952-53/1979/2003), “o enunciado - oral e escrito, primário e secundário, em qualquer esfera da comunicação verbal - é individual, e por isso pode refletir a individualidade de quem fala (ou escreve)” (p.283).

Bakhtin (1952-53/2003) aponta a existência não somente do estilo individual do falante, mas também considera o estilo próprio de cada gênero discursivo. "Em cada campo existem e são empregados gêneros que correspondem às condições específicas de dado campo; é a esses gêneros que correspondem determinados estilos.” (p.266). Ambos os estilos satisfazem aos gêneros discursivos.

Sendo o estilo elemento integrante do gênero discursivo, muitas vezes, o estilo individual não transparece ao estilo genérico. Alguns gêneros são mais suscetíveis a refletir a individualidade do enunciado do sujeito falante que outros, como é o caso dos gêneros literários, por exemplo. Diferentemente, os gêneros da esfera burocrática (ofício, requerimento, etc) ofuscam a presença do estilo individual.

Ao afirmar a suscetibilidade dos gêneros literários ao estilo individual, Bakhtin (1952-53/2003) ressalta que “(...) nem todos os gêneros são igualmente aptos para refletir a individualidade na língua do enunciado, ou seja, nem todos são propícios ao estilo individual” (p. 283).

O último elemento do gênero discursivo a ser definido é a forma composicional, que diz respeito ao tipo de estruturação que um enunciado assume de acordo com o gênero ao qual pertence. A forma composicional está ligada a uma "forma padrão e relativamente estável de estruturação de um todo”, segundo Bakhtin (1952-53//2003: 301) e pode ser considerada o seu elemento mais característico.

A forma composicional é a concretização de uma forma arquitetônica que se vincula diretamente ao objeto estético. Já, Grillo \& Olímpio (2006) complementam esta afirmação dizendo que "a forma composicional é a realização de uma forma arquitetônica por meio da organização de um material. (...) Essa organização se passa no nível da totalidade e das articulações composicionais das partes, dirigidas para uma finalidade”.

Enquanto o objeto estético dotado de sentido é criado no nível arquitetônico, a forma composicional se integra a ele de maneira constitutiva. Segundo Sobral (2005b), 
a forma composicional "é o modo específico de estruturação da obra externa a partir de sua concepção arquitetônica” (p.112).

Os aspectos teóricos levantados neste capítulo servirão de base para a compreensão das hipóteses apresentadas. O caráter dialógico da linguagem, bem como a constituição dos gêneros do discurso, são categorias conceituais fundamentais para as questões que se seguirão nos próximos capítulos. 


\section{Capítulo 2}

\section{Metodologia}

A organização metodológica da pesquisa foi delimitada a fim de se verificar a constituição do DDC por meio de seus gêneros discursivos na internet. Com o intuito de detalhar os procedimentos metodológicos utilizados, este capítulo está dividido em duas partes.

A primeira etapa detalhará, bem como justificará, a escolha do corpus. Já a segunda etapa tratará de descrever os critérios de análise que serão aplicados a partir das categorias conceituais da obra do Círculo de Bakhtin que foram apresentadas anteriormente. Para a análise do corpus serão empregadas as categorias conceituais discutidas previamente.

\subsection{Constituição do corpus}

O corpus é composto de três elementos: (i) gêneros discursivos pertencentes a um (ii) dossiê temático do (iii) site de divulgação científica Com Ciência $<$ www.comciencia.com.br $>$.

Com o intuito de esclarecer a forma com que o corpus foi constituído, o ponto de partida será o recorte maior, a revista eletrônica de divulgação científica Com Ciência. Em seguida, o foco incidirá sobre uma seção da revista que compreende um conjunto de enunciados sob forma de diferentes gêneros discursivos, os dossiês temáticos. Cada dossiê refere-se, respectivamente aos seguintes assuntos e anos: Energia Nuclear, 2000; Clonagem, 2002 e CélulasTronco, 2004. Finalmente, o recorte final do corpus será restringido aos gêneros artigo e reportagem extraídos dos dossiês temáticos.

\subsubsection{Com Ciência: revista eletrônica de divulgação científica}

A escolha pelo Com Ciência deu-se por dois motivos importantes para a averiguação das hipóteses lançadas neste trabalho, cuja pergunta de pesquisa debruça-se sobre a questão dos textos digitais. Primeiramente, trata-se de uma revista de divulgação científica exclusivamente eletrônica, ou seja, diferentemente 
de revistas impressas como Superinteressante, Ciência Hoje e Revista FAPESP, o Com Ciência não possui uma versão impressa. Em segundo lugar, a revista existe desde 1999 - o que se trata de longo tempo em termos de internet - e possui preocupação em realizar um trabalho de divulgação com respaldo institucional, no caso o Laboratório de Jornalismo (Labjor), da Unicamp.

Com layout e funcionamento familiar aos demais sites da rede de computadores, o Com Ciência instaura a prática da divulgação científica por meio de diversos gêneros discursivos, tais como, artigos, reportagens, notícias, resenhas, cartas ao leitor e entrevistas. Também apresenta glossários, filmografia e bibliografia sobre os assuntos debatidos.

A presença de colaboradores que pertencem tanto à esfera científica quanto à jornalística - pesquisadores e estudiosos de diferentes áreas da ciência e também jornalistas, que colaboram tanto na editoração do site, quanto na elaboração de reportagens - e a abordagem de temas da ciência caracterizam a revista no âmbito da prática da divulgação científica.

O site utiliza este conjunto de gêneros discursivos para tratar de temas diversos do campo científico e constitui, ao lado das modalidades de gêneros supracitadas, os chamados dossiês. Cada dossiê, também intitulado 'reportagem especial', conta com a participação de pesquisadores e cientistas da área em questão para a composição de artigos e de jornalistas para a composição das reportagens. Trata-se de uma série de textos, formatados em gêneros discursivos diferentes (em maior incidência artigos e reportagens) que abordam um mesmo assunto da ciência em comum.

A revista é desenvolvida por alunos do curso de jornalismo científico oferecido pelo Labjor, Unicamp, cujo principal objetivo é “promover um marco de referência para o processo de institucionalização das práticas do jornalismo e da divulgação científica no país” (Vogt: 2003, 83). O curso é organizado de modo multidisciplinar, o que se reflete na escolha dos temas de cada dossiê, e conta com a participação de pesquisadores de diversas áreas: biólogos, bioquímicos, engenheiros, advogados, médicos, entre outros.

Especificamente para a escolha dos temas, a revista possui um escopo próprio, como vemos a seguir: 
(a) assuntos divulgados pelos meios de comunicação de massa que envolvem, direta ou indiretamente, conhecimento científico; (b) pesquisas de ponta; (c) pesquisas de grande aplicabilidade ou geradoras de tecnologia e (d) pesquisas de interesse específico para o Brasil e para o Estado de São Paulo, relativas a todas as áreas da ciência (exatas, humanas e biomédicas) (Vogt: 2001, 110).

Além de desenvolver modos de produção e veiculação do site e de seu conteúdo discursivo, o Labjor também visa à análise dos modos de apreensão e recepção deste conteúdo pelo leitor internauta. Há dispositivos que permitem um estudo detalhado a respeito dos "percursos de leitura” dos usuários, bem como estatísticas de consulta dos mesmos, pesquisas de opinião e elaboração de perfis (tal como escolaridade, renda, ramo de atividade, faixa etária etc.), o que favorece uma maior reflexão acerca do trabalho desenvolvido pelo Labjor.

\subsubsection{Dossiês}

A partir da escolha da revista eletrônica Com Ciência para compor o corpus do trabalho, foram selecionadas três reportagens especiais, chamadas de dossiês. São compostas por textos de gêneros diferentes (reportagens, artigos e editoriais) e tratam de assuntos da esfera científica. Os dossiês escolhidos focam os seguintes assuntos: energia nuclear, clonagem e células-tronco. Faz-se necessário ressaltar que os diferentes assuntos foram, levando em conta a repercussão que instauraram na época de seu debate também em gêneros da mídia impressa e televisiva.

Os dossiês são datados, respectivamente, de 2000, 2002 e 2004. Este recorte diacrônico corresponde a um dos interesses da pesquisa, o de averiguar possíveis modificações que os enunciados presentes na internet sofreram durante esse período, uma vez que a tecnologia digital modifica-se e atualiza-se de forma rápida.

Considerando que a internet foi aberta ao público em 1995, ou seja, possui história recente, e as atualizações que vêm sofrendo até hoje, percebe-se que o seu índice de difusão é enorme. De acordo com o quadro apresentado por Pinho (2003, p.38), em que se verifica o intervalo entre a descoberta de um novo meio de comunicação e sua difusão, a internet pode ser considerada o veículo de comunicação de maior difusão mundial de todos os tempos. 


\begin{tabular}{|l|l|l|}
\hline Meio de comunicação & Tempo de aceitação & \multicolumn{1}{c|}{ Datas } \\
\hline Imprensa & 400 anos & De 1454 ao século XIX \\
\hline Telefone & 70 anos & $\begin{array}{l}\text { De 1876 até o período posterior à Segunda Guerra } \\
\text { Mundial }\end{array}$ \\
\hline Rádio & 40 anos & 1895 até o período entre as duas guerras mundiais \\
\hline Televisão & 25 anos & De 1925 até os anos de 1950 \\
\hline Internet & 7 anos & De 1990 até 1997 \\
\hline
\end{tabular}

Logo, para podermos identificar de que forma este fato interferiu nos gêneros discursivos e textos a serem analisados, procuramos espaçar a escolha dos dossiês em dois anos.

A utilização de hiperlinks para acessar textos, imagens variadas - gráficos, tabelas, fotos, ilustrações - e sumário interativo é comum a todos os volumes de dossiê escolhidos. O modo que os conteúdos são disponibilizados é que difere de um ano em análise para outro. A principal alteração foi o sumário que facilita o reconhecimento dos textos pelo leitor e sua navegação ao longo do dossiê temático.

Em 2000, com o tema Energia Nuclear: Custos de uma Alternativa, a revista não apresentava o sumário interativo, em que você clica o título e este remete ao texto de interesse, não era dividido em diferentes gêneros discursivos. Os gêneros não podem ser identificados como artigos ou reportagens até que não se verifique o conteúdo de cada texto.

Esse dossiê é composto por 14 reportagens, 3 artigos assinados, 1 tabela comparativa e filmografia. Há ainda glossário, referências bibliográficas cujos títulos estão on-line ou impressos. O dossiê conta com figuras, fotos, gráficos, tabelas a respeito do assunto e seus links remetem aos seguintes sites:

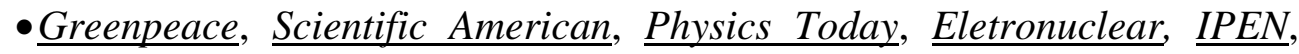
INB -Indústrias Nucleares do Brasil, Ciência Hoje e International Atomic Energy Agency.

Além de outros sites, os links interligam o texto a outros textos do mesmo dossiê, bem como a entrevistas e a um artigo em formato pdf. A função do hiperlink também é a de dirigir o leitor ao próximo texto, sem que ele tenha que voltar para o sumário novamente, o que leva a crer que os diversos textos formam uma seqüência de leitura que é sugerida ao leitor. 
O dossiê do ano de 2002, cujo tema é Clonagem Humana - A dessacralização da vida, traz algumas mudanças. Os textos vêm divididos por títulos de acordo com seu gênero discursivo, tais como editorial, reportagens, artigos, poema - gênero introduzido então -, o que antes não era feito de forma explícita. Torna-se mais evidente a distinção entre reportagens e artigos, pois o nome de todos os autores aparece no sumário também. Além disso, ao final de cada artigo é possível encontrar informações sobre a formação acadêmica do respectivo autor.

Além de o texto apresentar dados de seus autores é possível realizar o caminho inverso. Caso o leitor queira relacionar o autor ao texto, basta procurar a seção ‘créditos’ e clicar no nome do autor desejado para que haja remissão ao texto que ele escreveu. Os créditos também passam a apresentar itens extras, não pertencentes ao sumário do dossiê, como duas entrevistas e duas resenhas que, por sua vez, compõem outras seções da revista, bem como notas de rodapé em formato de hiperlink.

Mais especificamente nos artigos, há caixas intituladas 'Para saber mais', que possuem links eletrônicos para diversos sites. Os links encontrados foram os seguintes:

- Genetic Savings and Clone Inc., Human Cloning Foundation (com explicação sobre o que achar no site), Reproductive Cloning Network, El mundo (entrevista), Oxford Journals, Jen Tesarik, Human Cloning. Org, The Raelian Movement, Liberatión, Eurekalert (três artigos indicados), Scielo Brasil, Council of Europe, Andrology Institute of America, Human Fertilization \& Embryology Authority, Whitehead Institute for Biomedical research, Geron, The president's council on Bioethics, BioMedNet, Evangelium Vitae.

Do ano de 2004, foi selecionado o dossiê que discorre sobre o tema Célulastronco. Percebe-se que há a menor utilização de links e, quando utilizados, são colocados ao final de cada texto para indicar referências bibliográficas. A estrutura do sumário foi mantida.

Em cada reportagem ou artigo, a assinatura do autor passa a ser um hiperlink que é ligado diretamente aos créditos. Agora, há um movimento de remissão não 
somente dos créditos ao texto, como acontece em 2002, mas também, do texto ao crédito.

Nessa fase, há mudanças em relação aos hiperlinks que levam a sites externos. Ao contrário do que ocorria, os links, quando clicados, passam a abrir uma segunda janela, ou seja, uma página separada de acesso a outros sites, o que faz com que o leitor, aparentemente, não 'desvirtue’ sua leitura da janela inicial. Anteriormente, a possibilidade de navegar em outros sites e não retornar à leitura inicial era bem maior. Os links citados são:

- National Institutes of Health, Business Journal, The Scientist, National Cancer Institute, National Institutes of Diabetes \& Digestive \& Kidneys Diseases, $\underline{\text { Núcleo, }}$ Anvisa e SBPC.

\subsubsection{Artigos e reportagens}

Uma vez determinados os critérios de construção do corpus, reproduziremos, a seguir, os tópicos encontrados em cada dossiê, apresentando seus gêneros discursivos, artigo ou reportagem, bem como os títulos de cada texto, por meio de três tabelas. Cada uma corresponde, respectivamente, aos anos de 2000 (Energia Nuclear), 2002 (Clonagem) e 2004 (Células-tronco).

Tabela 1

\begin{tabular}{|l|c|}
\hline \multicolumn{1}{|c|}{ Data } & Agosto - 2000 - No. 12 \\
\hline \multicolumn{1}{|c|}{ Assunto } & Energia Nuclear: Custos de uma alternativa \\
\hline Energia nuclear: reascende o debate \\
\hline Mapa mundial \\
\hline Custos de produção \\
\hline Em funcionamento \\
\hline Estrutura da usina \\
\hline Monitoração ambiental \\
\hline Cracas e tubulações \\
\hline
\end{tabular}




\begin{tabular}{|l|}
\hline Plano de emergência \\
\hline História do projeto \\
\hline Lixo nuclear \\
\hline Duas opiniões sobre a energia nuclear no Brasil \\
\hline Domando a energia nuclear \\
\hline Uso do urânio \\
\hline Outras aplicações \\
\hline Transformações da energia - Ulisses Capozolli \\
\hline Fusão nuclear: alternativa? - Marcelo Knobel \\
\hline Perspectivas da fusão - Marcelo Knobel \\
\hline Tabela comparativa \\
\hline Glossário \\
\hline
\end{tabular}

Tabela 2

\begin{tabular}{|l|c|}
\hline \multicolumn{1}{|c|}{ Data } & \multicolumn{1}{c|}{ Janeiro - $2002-$ No. 27} \\
\hline Assunto & Editorial \\
\hline Clones e medos crônicos - Carlos Vogt \\
\hline Clonsacralização da vida \\
\hline Clonagem terapêutica ainda é promessa \\
\hline Leis restringem pesquisas com células-tronco \\
\hline Quem defende a clonagem humana \\
\hline Polêmica também envolveu primeiro bebê de proveta \\
\hline Clonagem humana é debatida por juízes brasileiros \\
\hline Políticos tentam regulamentar mundialmente a clonagem \\
\hline Clonagem já tem amplo uso na agropecuária \\
\hline Técnica não é novidade na agricultura \\
\hline Clonagem sob o olhar da religião \\
\hline
\end{tabular}




\begin{tabular}{|ll|}
\hline & Poema \\
\hline Proporções - Carlos Vogt \\
\hline \\
\hline
\end{tabular}

\subsection{Categorias descritivas}

A análise será desenvolvida, a partir do corpus delimitado, em dois capítulos. O primeiro será centrado nos gêneros discursivos artigo e reportagem, em que verificar-se-á a disposição e a utilização dos links eletrônicos, bem como a sua produtividade em cada um desses gêneros. Espera-se compreender os processos discursivos que serão analisados no âmbito dos gêneros escolhidos, a saber, artigos e reportagens que compõem as reportagens especiais do site de divulgação científica Com Ciência.

Ainda levando em conta os diferentes gêneros, o segundo capítulo destinado a análise do corpus terá as relações dialógicas estabelecidas pela remissão de links eletrônicos como categoria descritiva. A noção de dialogismo permitirá o estudo do envio a outros enunciados por meio do link eletrônico que ocorre em três planos distintos de remissão: remissão a textos internos ao dossiê, remissão a textos internos ao site Com Ciência e remissão a textos externos ao site Com Ciência.

As relações dialógicas serão analisadas a partir da disposição dos links, podendo ser encontrados sob diversas formas, tal como nota de rodapé, referência bibliográfica, explicação de um fato - remetendo a outra seção do próprio site ou a um segundo site, ou acréscimo de informação. O hipertexto constituirá a base para reflexão dos fatores acima que serão discutidos no momento da análise e, ao lado da noção de internet, será definido no próximo capítulo. 


\section{Capítulo 3}

\section{A estrutura do enunciado digital: a internet ${ }^{6}$ e o hipertexto}

A tecnologia da informação vem propiciando novas formas de se experimentar a comunicação e, dentre elas, a internet apresenta características importantes para reflexão no âmbito da linguagem. Isto porque as esferas da atividade humana, por meio dos diversos gêneros que as permeiam, estão se complexificando a partir do surgimento e da ampliação da internet.

Como afirma Marcuschi (2004), os estudos discursivos relacionados a um novo meio tecnológico e em desenvolvimento são passíveis de mudanças e reconsiderações. Nem por isso deixa de ser importante observar as contribuições do meio digital para a linguagem.

Com os estudos sobre a internet e o hipertexto digital em destaque, o debate sobre o seu impacto na comunicação humana vem se constituindo por posicionamentos extremos. Segundo alguns estudiosos que vêm se debruçando sobre o assunto, como o filósofo Pierre Levy e o lingüista David Crystal, o advento da internet é revolucionário para a linguagem, pois reflete novos parâmetros em diversos planos: no contínuo de fala e escrita; na criação de novos gêneros discursivos e adaptação dos gêneros do suporte impresso; nos processos de leitura e escrita; nas questões lingüísticas como as noções de coesão e coerência, por exemplo; e, principalmente, na reflexão sobre a teoria do texto empregada até então.

Certamente, todos esses novos parâmetros justificam a necessidade de revisão de certos conceitos empregados nos estudos da linguagem, bem como a criação de novos, uma vez que a tecnologia da informação pode modificar significativamente algumas das formas de comunicação.

David Crystal (2005), um exemplo de defensor extremo da rede neste contexto, chega a dividir os marcos da história da linguagem em três momentos cruciais: o surgimento da fala, o surgimento da escrita e o advento da comunicação mediada por computador (CMC). Crystal (2005) chega a considerar que "há (...)

\footnotetext{
${ }^{6}$ Termo originado da expressão Interaction or Interconnection between computer networks.
} 
algumas atividades lingüísticas permitidas pelo meio eletrônico que nenhum outro veículo consegue alcançar. É por isso que nos parece apropriado falar em ‘revolução’” (p.80).

Como representante do extremo mais cético em relação ao assunto, Sírio Possenti (2004), em Notas um pouco céticas sobre hipertexto e construção de sentido, questiona o caráter revolucionário que pesquisadores como Crystal e Marcuschi vêm atribuindo à tecnologia da internet e ao hipertexto digital, sobretudo a respeito da não-linearidade como seu fator principal. Primeiramente, relata a ocorrência da estrutura hipertextual em outros tipos de suporte que não o computacional, o que descaracteriza o caráter pioneiro do hipertexto em ambiente digital, tal como defendem alguns autores.

Além disso, aponta o problema da relação autor - leitor, rebatendo a idéia de Levy (1999) de que na internet o usuário leitor é co-autor do hipertexto digital. Segundo afirma Possenti, o leitor não tem o poder de prever o rumo que um link tomará. No exemplo abaixo, não se pode ter idéia para que direção o link 'crise' levará o enunciado A:

(1) Nos últimos meses, que mostraram que a solução não é nada trivial, instalou-se no país uma crise sem precedentes nesse setor.

Perante o contínuo de extremos de opiniões e posicionamentos, que enriquecem deveras esta discussão, procuraremos situar-nos em relação às questões levantadas por esses autores ao longo do trabalho. Para isso, será necessário explorar os aspectos mais relevantes da Internet e do hipertexto digital, bem como relacionar suas principais características ao processo enunciativo.

Este capítulo está dividido de modo a verificar, em um primeiro momento, a trajetória histórica da internet, mais precisamente, seu surgimento, difusão e expansão. Em seguida, serão elencadas suas principais características, para que, posteriormente, possamos entender sua contribuição para os elementos dos gêneros discursivos. Finalmente, observar-se-á quais são as características mais importantes do hipertexto digital, bem como as novas formas de leitura e letramento requeridos pelo texto eletrônico. 


\subsection{Internet}

O surgimento da tecnologia que levou à internet é um reflexo dos novos parâmetros econômicos, políticos e sociais impostos pela chamada Era da Informação, também reconhecidos como sociedade da informação. Manuel Castells (1999, p.82) afirma que "a criação e desenvolvimento da Internet nas três últimas décadas do século $\mathrm{XX}$ foram conseqüência de uma fusão singular de estratégia militar, grande cooperação científica, iniciativa tecnológica e inovação contracultural”.

O fato de a internet ser uma tecnologia da informação recente gera dúvidas e expectativas quanto ao seu futuro, bem como uma reflexão superficial de sua trajetória até agora. Isso porque os parâmetros ligados à rede estão em formação no mundo. Por fazermos parte deste processo sócio-histórico ainda recente, não foi possível criar o distanciamento necessário para refletir acerca de diversas questões.

Do ponto de vista tecnológico, a internet pode ser definida como um conglomerado de redes de milhões de computadores interligados ao redor do mundo, que permite o acesso a diversos tipos de informações e transferência de dados em larga escala.

Recentemente, autores como Pierre Levy e Manuel Castells começaram a discutir a internet além de sua condição tecnológica, mas como um espaço cultural e social, um espaço que abriga comunidades diversas e que promete "destituir as cidades de sua necessidade funcional” (Castells, 1999: 483), tornando-se um lugar para economia, comércio e relacionamentos.

Em sua obra Cibercultura de 1999, Levy compreende a internet como um espaço de comunicação, um tipo de mídia que vêm potencializando o diálogo em nível planetário. Em sua abordagem filosófica, assume a internet como Ciberespaço definido como

o novo meio de comunicação que surge da interconexão mundial dos computadores. O termo especifica não apenas a infra-estrutura material da comunicação digital, mas também o universo oceânico de informações que ele abriga, assim como os seres humanos que navegam esse universo. (Levy, 1999, p. 17) 


\subsubsection{Surgimento e expansão da rede mundial de computadores}

Ao contrário das redes de conexão pré-existentes, como visto em outros tipos de aparelhos eletrônicos - telégrafo, rádio e televisão - que possuíam sistemas tradicionalmente hierárquicos, esta rede foi inicialmente criada com o objetivo de proteger a base de dados militares dos Estados Unidos contra a exUnião Soviética. No entanto, a rede mundial de computadores extrapolou os limites da Guerra Fria para se consolidar como um dos principais veículos de comunicação da atualidade.

Durante a década de 1960, a possibilidade de uma intervenção nuclear por parte da União Soviética, logo após o lançamento do satélite Sputnik em 1957, suscitou a criação de um sistema que possibilitasse aos americanos a preservação de dados e informações importantes. Ainda durante a Guerra Fria, pensou-se em uma maneira de não armazenar todo esse banco de dados em uma única máquina já que a rede que interligava as bases militares passava por um computador central que se encontrava no Pentágono e sua comunicação era extremamente vulnerável. Logo, um sistema não-hierárquico, ou seja, não gerenciado por um único computador, começou a ser pensado e desenvolvido.

Mesmo com o fim da Guerra Fria, esta rede continuou a conectar os principais sistemas de computadores não só de bases militares, como também de dezenas de universidades e demais organizações de pesquisa nos Estados Unidos. Mais precisamente em 1969, a ARPA (Administração dos Projetos de Pesquisa Avançada do Departamento de Defesa dos Estados Unidos ${ }^{7}$ ), empresa responsável por conectar esses departamentos de pesquisa e a rede que interligava os computadores, criou uma rede batizada com o nome de ARPANET.

Em relação à ARPANET, Briggs \& Burke (2004) relatam que

\footnotetext{
(...) no início, tratava-se de uma rede limitada, compartilhando informação entre universidades (...) e outros institutos de pesquisa. Graças ao tipo de informação que estava sendo compartilhada, um elemento essencial de sua razão de ser era que a rede pudesse sobreviver à retirada ou destruição de qualquer computador ligado a ela e, na realidade, até à destruição nuclear de toda a "infra-estrutura" de comunicações. Era a visão do Pentágono. A visão das universidades era a de que a Net oferecia "acesso livre" aos usuários professores e pesquisadores, e que eram eles comunicadores. (p.310)
}

\footnotetext{
${ }^{7}$ Do inglês, Advanced Research and Projects Agency.
} 
Uma vez que o novo sistema da ARPANET contava com um backbone $e^{8}$ que passava por baixo da terra, a rede iniciou a conexão de indivíduos sem ter um centro definido ou uma mesma rota para as informações. A partir de então, na década de 70, houve uma grande difusão da Internet em meios acadêmicos americanos e a rede passou a ser experimental com o intuito de expandir-se ainda mais.

Na década de 1980, associada ao lançamento do computador pessoal (PC) no mercado pela IBM (1981), a configuração da Internet apresentava uma interface simples, apenas operacional. Na mesma época, foi gerada a interface gráfica por meio da qual a Internet é hoje utilizada, o World Wide Web (Rede de Abrangência Mundial). A WWW, como é chamada, baseia-se em hipertexto e vários outros recursos para a Internet e foi forjada também a partir das idéias de Ted Nelson, reflexo da "cultura hacker” da década anterior.

O termo internet passa a ser utilizado somente em meados dos anos 80 e o crescimento acadêmico atinge grande expansão. Nessa época, a NSF (Fundação Nacional de Ciência ${ }^{9}$ ), órgão americano de fomento à pesquisa, constituiu uma rede de fibra ótica de alta velocidade conectando centros de computação em pontos chave dos EUA.

Essas redes [NFS] trafegavam, em seu backbone, dados via computadores, voz (telefonia convencional), fibras óticas, microondas e links satélites. Batizadas de superhighways, essas redes conversavam entre si e ofereciam serviços ao governo, à rede acadêmica e aos usuários (Ferrari: 2004, p.16).

A rede, denominada "backbone da NSF" ou NSFNET, ainda tem sido de grande importância para o desenvolvimento da internet. Isso ocorre, porque esta nova rede reduz substancialmente o custo da comunicação de dados para as redes de outros computadores existentes.

Os anos 90 foram marcados pela democratização do uso da internet. Briggs \& Burke (2004) relatam que o grande avanço aconteceu entre setembro de 1993 e março de 1994, quando uma rede até então dedicada à pesquisa acadêmica se tornou a rede das redes, aberta a todos. Finalmente, em 1995, o controle da backbone mantido pela NSF encerrou-se passando para o domínio privado. Ainda

\footnotetext{
${ }^{8}$ Espinha dorsal de uma rede, uma estrutura composta de linhas de conexão de alta velocidade, que, por sua vez, se conecta a linhas de menor velocidade em várias sub-redes.

${ }^{9}$ National Science Foundation, ver glossário.
} 
neste ano, uma linguagem de programação chamada Java foi lançada no mercado pela empresa SUN. Tal linguagem de programação permitiu adicionar “conteúdo dinâmico” à páginas da WWW. Ao invés de páginas da Web contendo apenas textos e imagens gráficas estáticas, as páginas da Web agora podiam "ganhar vida” com áudio, vídeos, animações, interatividade, entre outros fatores que contribuíram para a popularização da rede (Deitel, 2003).

Desde então, os interesses comerciais, culturais, acadêmicos, cotidianos, profissionais, políticos, entre outros, passaram a constituir uma nova motivação para o uso da internet. Os usuários comerciais da internet dobram em relação aos usuários acadêmicos, o que demonstra um forte crescimento da vocação econômica da rede.

No Brasil, a introdução da internet foi realizada tardiamente, tendo como a primeira rede de acesso a Rede Nacional de Ensino e Pesquisa (RNP). Criada em setembro de 1989 pelo Ministério da Ciência e Tecnologia (MCT), teve como objetivo construir uma infra-estrutura, a fim de abrigar a rede para propósitos acadêmicos e de promover seu uso. Paralelamente, a RNP dedicou-se à divulgação da internet por meio de treinamentos, palestras e seminários, a fim de consolidar “uma consciência acerca de sua importância estratégica para o país”.

A internet começou a ser utilizada no país entre 1991 e 1993, após a realização de uma operação acadêmica da RNP subordinada ao MCT. Nesse período, há a criação de projetos educacionais, bibliotecas, armazenagem de informações virtuais, entre outras atividades realizadas pela RNP.

Já em 1994, a rede chegava a atingir todas as regiões do país e houve a consolidação do backbone nacional para a comunidade acadêmica. A internet só foi aberta ao setor privado em 1995, depois do serviço experimental lançado pela EMBRATEL, por meio de uma iniciativa do Ministério das Telecomunicações e do Ministério da Ciência e Tecnologia. A partir desse momento, a RNP sofreu uma mudança de foco e deu suporte ao surgimento de provedores e usuários da rede. A internet para cunho comercial foi, então, consolidada no país.

A partir de 1999, a internet passou a ser acessada em 26 estados brasileiros, tendo sua maior difusão em centros de pesquisas e universidades. Até os dias atuais, a RNP é o backbone principal do país e envolve diversas outras instituições como a FAPESP, além de universidades, laboratórios, entre outras. 
A agência mostra-se preocupada não somente com o desenvolvimento da Internet, mas também com a capacitação de profissionais em administração e segurança de redes. Sobretudo, a RNP "apóia a utilização de redes internet como facilitadoras do progresso da ciência e da educação em geral” e ainda, “opera a infra-estrutura nacional de rede avançada para colaboração e comunicação em ensino e pesquisa” (Instituto Tamis < $\underline{\text { www.rnp.br }}>$, acessado em 15 de maio de 2005).

Atualmente, a internet é estruturada por uma gigantesca rede mundial de computadores que são interligados por meio de linhas comuns de telefone, linhas de comunicação privada e outros meios de telecomunicação. A internet também é mediada por tecnologia wi-fi e toda ordem possível de comunicação sem fio. Os computadores que compõem a internet estão diluídos em diversas máquinas e podem estar localizados em qualquer lugar, até mesmo nas próprias residências. A internet não é controlada por nenhum tipo de instituição e seus "padrões e normas (...) são organicamente estabelecidos pela comunidade” (Pinho, 2003, p.5) que a utiliza.

Com a abertura da internet para a área comercial após os anos 1990, o chamado e-commerce, vários setores incorporaram rapidamente essa tecnologia, levando, ao público em geral, a comodidade do comércio de produtos e serviços de diferentes naturezas.

\subsubsection{Gêneros na internet}

Sendo a linguagem um dos fatores vitais que também permeiam a internet, como qualquer outro tipo de meio de comunicação, é um dos objetivos desta pesquisa observar o modo como a linguagem na internet está se complexificando cada vez mais, trazendo mudanças e influenciando os gêneros existentes em outros tipos de mídia.

Os gêneros podem ser definidos por sua forma, função e suporte e, logo, vê-se que os gêneros não podem ser representados sem suas ferramentas tecnológicas e que a tecnologia também incorpora gêneros discursivos diferentes. De acordo com Marcuschi (2004), isto se deve ao fato de a linguagem ser plástica e flexível, refletindo as transformações sociais, políticas e culturais. 
As inúmeras modificações nas formas e possibilidades de utilização da linguagem em geral e da língua, em particular, são reflexos incontestáveis das mudanças tecnológicas emergentes no mundo e, de modo particularmente acelerado nos últimos 30 anos, quando os equipamentos informáticos e as novas tecnologias de comunicação começaram a fazer parte de forma mais intensa da vida das pessoas e do cotidiano das instituições. Certamente, isso tem contribuído para tornar as sociedades letradas cada vez mais complexas (p.9).

Ou seja, como a nossa sociedade passa por um processo de complexificação, as formas de linguagem tendem ao mesmo processo, gerando e modificando os gêneros discursivos. Seguindo com os conceitos de círculo de Bakhtin (1979/ 1992, p. 262) sobre a mesma idéia, temos que

\footnotetext{
a riqueza e diversidade dos gêneros discursivos é imensa, porque as possibilidades da atividade humana são inesgotáveis e porque em cada esfera da práxis existe todo um repertório de gêneros discursivos que se diferencia e cresce à medida que se desenvolve e se complexifica a própria esfera.
}

A internet incorporou gêneros discursivos presentes em outros tipos de mídia, tais como aqueles encontrados em jornal, revista, televisão e rádio. Um exemplo disso são os jornais e revistas eletrônicas que possuíam uma diagramação e organização textual mais próxima do texto impresso. Hoje em dia, já é possível observar que a internet vem imprimindo um novo modo de veicular a informação, já que sua tecnologia é capaz de reunir recursos variados que lhe permitem operar ao mesmo tempo com o texto escrito, o som e a imagem. O advento da tecnologia computacional fez com que gêneros discursivos sofressem adaptações: encurtamento dos textos, uso de links eletrônicos, uso da hipermídia, diferente aproveitamento de infográficos, entre outros.

Pinho (2003) destaca como características importantes da internet. A (i) instantaneidade corresponde à velocidade de veiculação e renovação de conteúdo propiciada pela tecnologia digital. A rede é alimentada por novos conteúdos a todo o momento e a tendência do mercado tecnológico é fazer com que essa característica seja potencializada cada vez mais.

Outros dois aspectos que particularizam a internet são a (ii) dirigibilidade e a (iii) qualificação necessária de seus usuários. A dirigibilidade diz respeito à capacidade propiciada pela internet de se poder disponibilizar conteúdo sem restrições de tempo e espaço, ao contrário de outros tipos de mídia. O usuário 
poderá buscar por informações de forma quase ilimitada, em diversas fontes de conteúdo presentes na internet.

Embora sua dirigibilidade seja bastante abrangente, atendendo a diversos tipos de pessoas cujos interesses são distintos, exige-se que o usuário tenha conhecimento específico para navegar o computador e, conseqüentemente, a internet. Trata-se da qualificação. Diferentemente da televisão, cujo manuseio dáse por um controle remoto, ou mesmo de um rádio, que pode ser controlado de forma simples, o uso da rede pressupõe conhecimentos de uso do computador e dos sistemas e programas que acessam a internet.

Por outro lado, Pinho (2003) afirma que a internet é acessada por um público majoritariamente jovem e qualificado, com alto nível de escolaridade, elevado poder aquisitivo e com um perfil ocupacional diferenciado, o que representa uma fatia mínima tanto da nossa população quanto da população mundial. Aliás, o problema da exclusão digital provocado pela falta de letramento e educação voltada para o uso da tecnologia é um dos grandes problemas que deverá ser enfrentado por nossa sociedade. Segundo afirma Pereira (2005), “o problema central que uma sociedade da informação deve vencer, em primeira instância, é o da exclusão digital”, pois "precisamos dominar a tecnologia para que, além de buscarmos a informação, sejamos capazes de extrair conhecimento” (p.17-18)

Tendo em vista tais aspectos, é plausível dizer que os gêneros emergentes dessa nova tecnologia digital, de acordo com a definição de Marcuschi (2004), portam-se de maneira diferente. Para Marcuschi (2004: 14), há alguns aspectos que devem ser levados em consideração em relação aos novos gêneros emergentes do discurso digital:

(1) seu franco desenvolvimento e um uso cada vez mais generalizado; (2) suas peculiaridades formais e funcionais, não obstante terem eles contrapartes em gêneros prévios; (3) a possibilidade que oferecem de se rever conceitos tradicionais, permitindo repensar nossa relação com a oralidade e a escrita.

O desenvolvimento acelerado e o uso cada vez maior dos gêneros digitais devem-se, entre outros fatores, à interatividade proporcionada pela velocidade de trânsito das informações na rede que acontece não só de um internauta para com um texto, mas, também, de um internauta para outro, ou seja, entre indivíduos. 
A capacidade de interação entre os internautas se dá pela acessibilidade da Internet - 24 horas por dia, o ano inteiro - e pela presença de um receptor ativo que possui milhares de possibilidades na busca pela informação na rede. Ou seja, a qualquer momento em que a internet for acessada será possível interagir com algum outro internauta e de diversas formas.

Em relação a suas características formais e funcionais, como descrito, podese destacar o próprio modo com que o computador afeta essa interação, por exemplo, no caso da leitura. Ao ler diretamente da tela de um computador, nosso modo de apreensão é alterado fisiologicamente pelo fato de as imagens e caracteres serem projetados por meio de luz.

Finalmente, pode-se observar a interferência sofrida pela modalidade escrita da língua por diversas outras, tais como oral, visual, musical e digital, o que resulta dos fatores funcionais e formais supracitados, em muitos gêneros. Basta observar um diálogo em chats ou fóruns em que internautas utilizam termos tais como naum para expressar ‘não’ e intaum para ‘então’.

\subsection{Hipertexto digital}

Apesar de originalmente ter se alimentado de gêneros de diferentes mídias para compor a sua organização textual, a particularidade que mais distancia a internet dos outros tipos de mídia é, certamente, o modo com que atualmente disponibiliza seu conteúdo. A estrutura do texto veiculado na rede permite ao usuário leitor acessar vários tipos de informações e até navegar simultaneamente por outros sites por meio dos elos eletrônicos chamados hiperlinks ${ }^{10}$, que possuem “um papel relevante na construção de sentido nos textos virtuais” (Cavalcante, 2004).

Tecnicamente, o hipertexto é um sistema para a visualização de informação cujos documentos contêm referências / nós para outros documentos por meio de links eletrônicos. Produto de diferentes informações digitais interconectadas, também utiliza sons, imagens e diagramas, a fim de permitir que o leitor decida o modo com que a sua leitura deve avançar. Essa estrutura hipertextual eletrônica, segundo Levy (1999: 33) pode ser definida por um "conjunto de nós ligados por

\footnotetext{
${ }^{10}$ Hiperlinks são conexões que interligam os computadores da rede.
} 
conexões. Os nós podem ser palavras, imagens, gráficos ou parte de gráficos, seqüências sonoras, documentos complexos que podem eles mesmos serem hipertextos”, completa Levy, definindo o hipertexto digital da seguinte forma:

\footnotetext{
Se tomarmos a palavra 'texto' em seu sentido mais amplo (que não exclui nem sons nem imagens), os hiperdocumentos também podem ser chamados de hipertextos. A abordagem mais simples do hipertexto é descrevê-lo, em oposição a um texto linear, como um texto estruturado em rede. (pág.55)
}

Sob o ponto de vista lingüístico, temos uma gama de opiniões diferentes não somente no âmbito terminológico, mas também no plano das definições por parte dos autores que vêm se dedicando à pesquisa em torno do hipertexto digital. Verifica-se que poucos têm uma preocupação em ressaltar e descrever a existência da estrutura hipertextual fora do suporte eletrônico, bem como em explicitar o seu percurso histórico até a chegada ao ambiente virtual, ao contrário de pesquisadores como Wandelli (2003) - cuja obra dedica-se à comparação do hipertexto em suporte impresso e digital -, Cavalcante (2004) e Marcuschi (2004 e 2005).

Enquanto Marcuschi (2004) descentraliza o caráter não linear da hipertextualidade e elege a presença do link eletrônico como seu fator fundamental, Xavier (2004) minimiza a participação desses nós eletrônicos ao processo de referenciação no hipertexto. Levy (1999), na mesma linha do pensamento de Marcuschi, caracteriza o hipertexto "por nós (os elementos de informação, parágrafos, páginas, imagens, seqüências musicais, etc.) e por links entre esses nós, referências, notas, ponteiros, “botões” indicando a passagem de um nó a outro.” (p. 55-56). Ou seja, para Levy o fator que determina a hipertextualidade é a presença dos links eletrônicos.

O hipertexto ocorre por meio de mecanismos distintos, podendo ser os links eletrônicos em ambiente digital, a numeração nas notas de rodapé de um livro, os números das páginas em um índice ou sumário, etc. Trata-se de uma rede de textos / enunciados interconectada por elos discursivos que nada mais são do que os mecanismos supracitados.

Sob esta perspectiva, a presença do link eletrônico pode ser o seu fator central, como afirmam Marcuschi e Levy, pois esse possibilita mais sistematicamente a estrutura em rede não-linear. 
No entanto, resta saber se o link (ou qualquer outro mecanismo de nós discursivos) determina o hipertexto, ou se esta estrutura, que está se modificando ao longo do tempo - e vem sendo utilizada bem antes de ser discutida no meio acadêmico - fez que esses nós emergissem em sua estrutura, apontando, cada vez mais, para fora de si, como uma especialização do processo de referenciação, segundo afirma Xavier. De qualquer maneira é preciso olhar para ambos os lados, pois estes dois fatores não se anulam e são complementares: o link é fator constituinte do hipertexto, mas só existe por conta deste. Um não acontece sem o outro.

Muitas denominações são atribuídas ao hipertexto que ocorre em ambiente computacional, o que levanta uma questão terminológica. Por exemplo, Marcuschi (2000) o denomina hipertexto internetiano, enquanto Galli (2004) prefere o termo hipertexto virtual. Há ainda o termo hipertexto eletrônico, utilizado por outros autores. Como forma de diferenciar o hipertexto em ambiente digital, mas, ao mesmo tempo, sem desconsiderar a validade das terminologias empregadas pelos outros autores, optou-se, neste trabalho, por denominá-lo hipertexto digital.

\subsubsection{Breve histórico do Hipertexto digital}

Em meio à revolução dos computadores e ao surgimento da internet, devese destacar a criação do hipertexto. A noção de hipertexto, terminologia criada por Theodore Nelson em 1974, a partir de seu folheto Computer Lib, resultou da proposta de introdução de uma rede eletrônica que possibilitasse acesso instantâneo a qualquer tipo de documento. Nelson imaginou um sistema capaz de organizar diversos tipos de informação, chamado de 'hipertexto', fundamentado em remissões horizontais.

Os links eletrônicos também foram idealizados por Nelson, compartilhando do pensamento de Vannevar Bush, inventor da Memex. Em 1945, Vannevar Bush escreveu o artigo "As We May Think", sobre o "Memex" que serviu de inspiração para a idealização do hipertexto. Tratava-se de uma máquina com capacidade de criar leitura e escrita não-lineares, bem como armazenar uma biblioteca multimídia de documentos. O sistema utilizado, que foi denominado Augment, era responsável por programar links em arquivos eletrônicos. O Memex não só referenciava 
informações ao usuário, como consistia em uma ferramenta para seguir esses elos e estabelecê-los.

Conforme descreve Dias (1999)

os pontos fortes desse sistema eram as inúmeras facilidades que propiciavam o trabalho colaborativo e uma melhor interface entre o usuário e o computador. Dentre os mecanismos de colaboração implementados nesse sistema, podemos citar: mensagens eletrônicas, teleconferência, compartilhamento e arquivamento de mensagens (p.6).

Mais tarde, na década de 1990, a World Wide Web (WWW), que foi idealizada por Tim Berners-Lee, definiu a maneira com que o hipertexto tem se desenvolvido nos últimos tempos.

Embora esta terminologia tenha emergido por conta do desenvolvimento da área computacional nas décadas de 1960 e 1970, a estrutura hipertextual é anterior e ocorre paralelamente ao advento da tecnologia digital, sendo possível verificar a sua ocorrência fora do suporte computacional. Esta forma de estruturar o texto pode ser encontrada em diferentes veículos e gêneros, como por exemplo, nas notas de rodapé de um artigo científico ou mesmo nas digressões de um diálogo entre amigos.

Para Levy (1999), até mesmo uma biblioteca pode ser considerada uma forma de hipertexto, uma vez que "nesse caso, a ligação entre volumes é mantida pelas remissões, as notas de rodapé de página, as citações e as bibliografias. Fichários e catálogos constituem os instrumentos de navegação global na biblioteca” (p.56).

Torna-se importante esclarecer que trataremos de um tipo de hipertexto que ocorre especificamente no ambiente eletrônico e que se apresenta em muitos gêneros da internet, o hipertexto digital. Este dado é importante, uma vez que o caráter digital permite "a associação na mesma mídia e a mixagem precisa de sons, imagens e textos” o que traz uma “diferença considerável em relação aos hipertextos que antecedem a informática” (Levy, 1999, p.56).

\subsubsection{Funções do link eletrônico: linearidade e a construção de sentidos}


A recuperação de outros enunciados, da maneira como é viabilizada na internet, vem modificando modos de leitura e escrita, bem como aspectos estritamente lingüísticos, de nível morfológico e mesmo sintático. No entanto, o jogo dialógico formado pelos nós eletrônicos que interligam diferentes textos é uma característica marcante do hipertexto digital, pois constitui, literalmente, as réplicas de um grande diálogo.

As relações estabelecidas pelo link eletrônico não são puramente lingüísticas, mas sim, antes de tudo, relações semânticas, de ordem dialógica. “A relação com a coisa (em sua materialidade pura) não pode ser dialógica (...)”. A relação com o sentido é sempre dialógica.” (Bakhtin: 1979, p.327). Ou seja, a compreensão conferida ao processo dialógico não se dá apenas por conta da materialidade da língua e dos aspectos puramente lingüísticos, mas também se vale deles para estabelecer as relações de sentido.

O link eletrônico faz parte de um todo de enunciado, ou fragmento de um determinado enunciado, ao mesmo tempo em que recupera algum outro. Logo, o enunciado determinado como link eletrônico faz parte de dois planos discursivos distintos. Observe o fragmento abaixo:

(2) Vários segmentos da sociedade têm assumido uma posição contrária às pesquisas com células-tronco embrionárias, alegando que o início da vida humana ocorre no momento da concepção, tornando assim a pesquisa com embriões injustificável e anti-ética. Outra argumentação é a de que se estaria abrindo também a possibilidade de que fossem produzidos embriões humanos que serviriam como fonte de célulastronco embrionárias, com possibilidade inclusive de comercialização dos mesmos.

Neste exemplo, o link eletrônico ‘comercialização’ faz parte do enunciado acima transcrito. Ao mesmo tempo, se nele clicarmos, seremos transpostos a outro enunciado, a outro fragmento discursivo. O enunciado, neste caso, participa de dois planos de sentido diferentes, porém complementares, em que será instaurado o dialogismo hipertextual.

O link eletrônico é o fator que essencialmente indica a complexificação da linguagem na internet, pois, em contraposição aos nós discursivos de outros 
suportes, este potencializa a face hipertextual dos enunciados na internet e nos programas computacionais. Aliás, o link é o que destaca a hipertextualidade digital dos outros tipos de hipertexto e pode ser considerado responsável pelo caráter “revolucionário” apontado por estudiosos como Crystal (2004), no início deste capítulo.

Os links eletrônicos, em sua estruturação hipertextual, remetem o interlocutor diretamente a outros enunciados que são selecionados pelo locutor. Tomando a noção de enunciado como sendo um elo na cadeia da comunicação verbal, tal como proposta pelo círculo de Bakhtin $\left(1952-53\right.$ / 2003) ${ }^{11}$, temos o link eletrônico funcionando como um elo na cadeia da comunicação verbal digital. Mais do que ponte digital entre conteúdos, o link possibilita diferentes formações de sentido e a criação de novos percursos discursivos de leitura. Cavalcante (2004) atribui importância aos links "na construção de sentido nos textos virtuais” (p. 163).

Levy (1999) relata que, ao participar da estruturação de um texto, o usuário, apesar da pré-seleção do locutor, não apenas irá escolher quais links preexistentes serão usados, mas irá criar novos links, que terão um sentido para ele e que não terão sido pensados pelo criador do hiperdocumento (p. 57). A possibilidade de diálogo entre diferentes enunciados torna-se possível porque o link funciona como um ponto de contato entre dois enunciados. Quando deparamos com um fragmento - que pode ser verbal (uma palavra ou uma sentença) ou, muitas vezes, não-verbal (tal como um número, uma figura ou um símbolo) - em letra azul sublinhada, temos não somente parte de um enunciado que já havia sido constituído, mas também, o início de um novo enunciado ou de novos enunciados.

A deslinearização é vista como um dos principais fatores presentes na produção do hipertexto. Xavier (2004: 175) afirma que a “inovação trazida pelo texto digital eletrônico está em transformar a deslinearização, a [aparente] ausência de um foco dominante de leitura, em princípio básico de sua construção”.

A não-linearidade não deve causar prejuízos ao entendimento do leitor, pois não se trata de um montante de uma cadeia de enunciados justapostos. Na verdade, a não-linearidade do hipertexto está nas escolhas de qual caminho de leitura o usuário quer trilhar, a fim de construir um sentido que lhe seja próprio e oportuno por meio dos links.

\footnotetext{
${ }^{11}$ A referência remete a Bakhtin, porém representa o pensamento do círculo bakhtiniano.
} 
A noção de não-linearidade, no entanto, pode ser anulada se considerarmos que a construção de sentido vai sendo constituída na medida em que o usuário avança em sua leitura por meio dos nós. O sentido vai sendo estabelecido na relação entre os enunciados e o indivíduo encontrará novas significações a cada escolha no percurso discursivo de leitura. Neste caso, a relação de significação estabelecida pertence a um momento particular, que dificilmente se repetirá na leitura de indivíduos diferentes.

A experiência de um hipertexto digital exige que o leitor "vivencie uma experiência de leitura sinestésica, o que concorre para uma atividade de leitura multisensorial” (Xavier, 2004 p. 176). Em contato com o texto digital, o leitor é levado pelas relações de sentido estabelecidas pela ordem não linear de leitura, mas ligadas a um foco de leitura.

Segundo Levy (1999), os hiperdocumentos dispostos na rede são poderosos instrumentos de escrita-leitura coletiva. Assim como ocorre em qualquer texto, o leitor transforma-se em co-autor e complementa:

Tudo se dá como se o autor de um hipertexto constituísse uma matriz de textos potenciais, o papel dos navegantes sendo o de realizar algumas desses textos colocando em jogo, cada qual à sua maneira, a combinatória entre os nós. O hipertexto opera a virtualização do texto. (1999, p. 55)

Ferrari (2004, p. 43) consolida este pensamento ao dizer que "tornando-se um escritor enquanto lê, todo leitor Web consegue reconfigurar a informação de acordo com suas preferências e hábitos de leitura”. Isto também ocorre na leitura de um livro, por exemplo.

Porém, a idéia de que o leitor seja co-autor do texto digital merece ressalvas. É plausível dizer que o leitor participa do processo de construção de sentido utilizando os enunciados pré-dispostos na rede. No entanto, é preciso considerar que estes enunciados constituem unidades de sentido, ou seja, não estão ali colocados de forma aleatória nem fora de um contexto específico. O leitor não age no plano da produção textual em si, mas no plano da contextualização. Logo, seria inadequado dizer que o leitor torna-se co-autor, uma vez que, mesmo tendo uma relação diferenciada com o texto digital por conta de sua mobilidade, ele atua em outra dimensão que não a do autor. 
Retomando a idéia de Possenti apresentada no início do capítulo, há um segundo fator que nos leva a crer que esta equalização não seja possível: a previsibilidade. O leitor não é capaz de saber se um link, quando acessado, o levará a uma direção ou outra, isto é, ele não sabe previamente o rumo que sua leitura tomará.

Possenti questiona ainda a constituição desse leitor enquanto sujeito discursivo, que possui interesses próprios e uma história. Assim, as escolhas feitas por esse leitor também não são aleatórias, ao mesmo tempo em que lhe impõem certo limite de acesso. Dessa forma,

\footnotetext{
um leitor sem história é um leitor não só sem ideologia, mas também sem profissão, sem nenhuma pressão do mercado e das instituições, pressões que, acredito, o levam a fazer com as possibilidades do hipertexto aquilo que deve fazer de qualquer forma. O leitor com história, levado ao limite, é o leitor interpelado pela ideologia e submetido por sua formação discursiva, e, seja ou não patrulhado, lerá só o que pode ler, com algumas exceções e pequenas escapadas, independentemente dos meios que tiver a sua disposição (2004: p. 218).
}

Procurou-se, até o momento, contextualizar historicamente a evolução da internet como tecnologia e a criação do hipertexto digital, bem como sua contribuição para a sociedade mundial. Como mostra Levy, a tecnologia não determina a sociedade e a cultura, mas sim, gera condições para que haja um processo amplo de desenvolvimento e adequação das duas. "Uma técnica é produzida dentro de uma cultura, e uma sociedade encontra-se condicionada por suas técnicas” (Levy, 1999: 25). Em seguida, serão trazidas as perspectivas adotadas nesta dissertação acerca da internet e hipertexto.

\subsection{Internet e hipertexto digital: definições do ponto de vista bakhtiniano}

Dadas as definições a respeito da internet e do hipertexto digital descritas neste capítulo, serão apresentadas as concepções adotadas nesta pesquisa acerca desses elementos com base na teoria do Círculo bakhtiniano.

Considerando os aspectos tecnológicos, que definem a internet como um conglomerado de redes de computadores e a abordagem filosófica de Levy (1999) que trabalha com a concepção de ciberespaço, sob o ponto de vista da linguagem, a internet será encarada como um conjunto de diferentes esferas. 
As esferas de atividade humana são o espaço em que as especificidades dos mais variados enunciados constituem os gêneros. Segundo Bakhtin (195253/2003), as esferas elaboram seus tipos relativamente estáveis de enunciados sendo esses tipos denominados gêneros discursivos. Cada esfera emprega seus gêneros que correspondem às suas condições específicas.

\footnotetext{
Uma determinada função (científica, técnica, publicística, oficial, cotidiana) e determinadas condições de comunicação discursiva, específicas de cada campo [esfera], geram determinados gêneros, isto é, determinados tipos de enunciados estilísticos, temáticos e composicionais relativamente estáveis. (Bakhtin, 1952-53/2003, p. 266)
}

Associada a esta definição de esfera, pode-se considerar a internet um espaço de interação verbal que, em sua complexidade, abriga diferentes esferas, uma vez que atende a suas diferentes condições de comunicação discursiva. Diferentemente do que aponta Araújo (2004), a internet não será considerada nesta dissertação como uma única esfera, a qual o autor denomina 'esfera eletrônica' (p.109), devido à sua capacidade de conter diferentes funções e condições discursivas, comportando gêneros discursivos de diferentes esferas. De acordo com esta definição, os chats e as conversas entre amigos ainda continuariam a pertencer à esfera da ideologia do cotidiano, assim como os artigos científicos, à esfera científica, os gêneros reportagem apresentados por um site de notícias, à esfera jornalística e assim por diante.

Utilizando outra categoria conceitual do Círculo, a questão do hipertexto também pode ser elucidada. Ao longo do capítulo, o hipertexto também foi abordado, tecnicamente, como um sistema para a visualização que contém referências internas para outros documentos por meio de links eletrônicos. As abordagens lingüísticas apontaram para o uso do link como derminante para a composição da estrutura do hipertexto na internet, que foi denominado hipertexto digital.

Contudo, faz-se necessário pensar o hipertexto frente aos diferentes tipos de relações dialógicas estabelecidas entre enunciados. O dialogismo, segundo a teoria bakhtiniana, compreende a capacidade responsiva contida no interior de cada enunciado de relacionar-se a outros enunciados. As relações dialógicas estabelecidas entre eles podem ser implícitas, evocando o eco de outros enunciados em seu interior, ou explícitas, como a concretização do intertexto. 
A intertextualidade, por sua vez, traz fragmentos de outros enunciados para dentro do texto, podendo-se utilizar diferentes formas de citação e referência a outras falas e enunciados. É travada uma relação dialógica intertextual.

No entanto, ao refletir acerca do hipertexto, percebe-se que o diálogo com outros enunciados é determinado de forma distinta, não trazendo o fragmento de outros textos para o interior de um enunciado, mas utilizando o links eletrônicos. O link não materializa o texto citado, como faz o intertexto, mas o presentifica, ou seja, possibilita a um diálogo com outros enunciados, estabelecendo uma relação semântico-axiológica, remetendo para fora do texto. Logo, as remissões a outros enunciados encontradas no hipertexto, no caso do hipertexto digital realizadas pelos links, serão consideradas relações dialógicas hipertextuais.

De acordo com o posicionamento teórico tomado em relação a internet enquanto conjunto de esferas e as relações dialógicas hipertextuais realizadas por meio dos links, serão apresentados aspectos relacionados a divulgação científica. 


\section{Capítulo 4 \\ Divulgação Científica}

A prática da Divulgação Científica (DC) científica vem espalhando-se, cada vez mais, por diferentes meios de comunicação, ocupando mais espaço nos noticiários diários de grande alcance da população. Os sites de divulgação científica ou mesmo a versão digital de revistas de divulgação impressas são uma prova disso. Contudo, na medida em que a DC conquista espaço na sociedade da informação, por conta das novas tecnologias de comunicação e da própria necessidade de disseminação da ciência, surgem diversas questões sobre o papel que realmente tem se proposto a cumprir.

Este capítulo tem o objetivo de pontuar as questões mais relevantes sobre a função e definição da DC, bem como seu estatuto no âmbito da linguagem. Para isso, é necessário entender, primeiramente, o que diferencia a prática da divulgação científica do jornalismo científico. Em seguida, tratar-se-á da cultura científica, lugar em que a DC se inscreve na sociedade.

Sob o ponto de vista lingüístico, serão analisadas as propostas de AuthierRevuz, Zamboni e de demais autores da análise do discurso. Finalmente, levar-seá em conta a contribuição do círculo de Bakhtin para a constituição do discurso de DC.

Sendo o corpus da pesquisa um recorte de artigos e reportagens de DC na internet, cabe aqui verificar como se dá esta prática no meio digital, ressaltando suas problemáticas e perspectivas, bem como caberá a apresentação e os propósitos do site escolhido para análise, o Com Ciência.

\subsection{Jornalismo científico e divulgação científica}

O jornalista Wilson da Costa Bueno (1984) faz uma distinção entre jornalismo científico (JC), disseminação científica e divulgação científica (DC) e questiona os efeitos que cada uma destas categorias tem sobre a linguagem, bem como sobre o discurso utilizado em cada uma delas.

Para Bueno, tanto a disseminação quanto o jornalismo científico estariam sob o escopo da DC, ao lado de outras formas de divulgação. O que as diferencia 
é o público a que são dirigidos, sendo que a primeira está voltada para a difusão do conhecimento entre pares científicos, ou seja, entre os cientistas e pesquisadores, e a segunda, voltada para o grande público em geral. A partir daí as diferentes funções que cada categoria assume acarreta especificidades para a linguagem, bem como para o discurso utilizado por elas.

Em artigo publicado em seu site, Jornalismo Científico, Bueno aponta o JC como uma forma particular de divulgação científica que "diz respeito à divulgação da ciência e tecnologia pelos meios de comunicação de massa, segundo critérios e o sistema de produção jornalísticos” ${ }^{12}$. Isto é, o JC constitui apenas uma das formas de divulgação para o público em geral que obedece aos padrões lingüísticos da prática jornalística.

A disseminação científica possui como alvo “os especialistas, os próprios pesquisadores e cientistas”, ocorrendo em revistas e periódicos científicos, congressos e demais eventos, entre outros gêneros da esfera científica. Tanto o JC quanto a disseminação exprimem "manifestações diversas do processo de difusão de informações sobre ciência e tecnologia”.

A DC, segundo Bueno, estaria voltada a um público universal, considerando a difusão entre os pares (da mesma área ou não, mas pertencentes à esfera científica) e a difusão para a população que não está inserida na esfera científica. A DC não pressupõe, necessariamente, o JC, mas sim o contrário. Apesar de ambos terem como função a democratização das informações científicas, a DC pode constituir-se não só na prática jornalística, mas também no âmbito educacional, por exemplo.

De acordo com Vogt (2006) o "projeto fundamental e histórico da divulgação das ciências e das tecnologias” é o de "aproximar, compartilhar e estimular” (p.20). O autor considera que a DC constitui parte de um objeto maior que vem sendo chamado de cultura científica.

Na verdade, a prática da DC ainda está em formação, principalmente no Brasil. Segundo aponta Tuffani em seu artigo $O$ fogo cruzado do jornalismo de ciência (2002), esses profissionais enfrentam algumas situações problemáticas. A primeira delas diz respeito ao público alvo. De acordo com Tuffani, escreve-se a uma entidade fictícia, o leitor-médio, considerado "incapaz de compreender

\footnotetext{
${ }^{12}$ Extraído de http://jornalismocientifico.co.br/conceitojornacientifico.htm, acessado em 02/09/04.
} 
qualquer matéria que não tenha sido elaborada sob o mais severo didatismo” (p. 1). Considerando esse leitor-médio, Moirand (2000) aponta para o esforço da mídia em fazê-lo ver, mais do que fazê-lo compreender. A partir daí, tem-se "seqüências de discursos fragmentados que remetem a universos de referências científicos” (p.11).

A segunda problemática envolvendo o JC seria a consulta das fontes. Apenas recentemente observa-se o esforço da comunidade científica em baixar guarda para os profissionais do jornalismo, e o mesmo esforço destes para especializarem-se ao máximo acerca das questões científicas de que tratam. Logo, já há cursos de especialização em pós-graduação para cientistas e jornalistas, que fazem um percurso contrário na busca de saberes para atuarem em DC. Os primeiros buscam se adequar ao modo de fazer jornalístico e os segundos, conhecimento mínimo na área científica para relatarem os acontecimentos e processos com maior credibilidade.

\subsection{Cultura científica}

Em seu artigo, A Espiral da cultura científica ${ }^{13}$, publicado na edição $n^{0} 45$ dos dossiês do site Com Ciência e embrião do livro Cultura Científica (2006), Vogt lança mão de argumentos que o fizeram chegar à noção de Cultura Científica.

Vogt anuncia que arte e ciência, deixando de lado distinções teóricas e metodológicas, compartilham da mesma finalidade. Ou seja, criar e gerar o conhecimento, por meio de conceitos abstratos, mas, ao mesmo tempo, tangíveis. “No caso da Ciência, essa tangibilidade e concretude se dá pela demonstração lógica e pela experiência; no caso da Arte, pela sensibilização do conceito em metáfora e pela vivência” (p.1). Ou seja, a ciência é constituída por um processo complexo que não o de simples observação e descrição dos eventos do mundo e da natureza.

Além disso, Vogt aponta para o fato de a expressão "Cultura Científica” poder representar todos os processos que vêm sendo atribuídos à prática da DC, incorporando-os ao seu campo semântico termos como alfabetização científica

\footnotetext{
${ }^{13}$ Extraído de http://www.comciencia.br/reportagens/framereport.htm, acessado em 24/02/07
} 
(Scientific literacy), popularização e vulgarização científica, percepção/compreensão pública da ciência (public understanding/awereness of science). A respeito do uso desses termos, Vogt (2003) afirma que

\begin{abstract}
há, entre as culturas de língua inglesa, variações de antagonismos que, por zelo de sutileza, distinguem, por exemplo, public understanding of science de public awereness of science, introduzindo na segunda elementos de percepção e consciência que não estariam necessariamente presentes no simples entendimentos público da ciência. (p.92)
\end{abstract}

Lévy-Leblond (2006) critica o uso dos termos public understanding/awereness of science, por entender que a problemática não está em compreender o conhecimento, uma vez que este pressupõe poder. A questão está em torno da detenção do poder e não do conhecimento em si. Além disso, o autor sugere que a utilização de tais termos faz com que haja uma distinção na população entre aqueles que detêm o conhecimento, os cientistas, e o públicoleigo.

Esta discussão abre portas para outro questionamento. Na sociedade da informação em que as especializações acerca das informações veiculadas têm tomado uma proporção sem precedentes, o que se pode considerar em termos de público-leigo? O especialista em determinada área não detém os saberes de outras áreas, tornando-se leigo fora do escopo de sua linha de pesquisa.

Isto também coloca em debate a distinção que Bueno (1984) faz em relação à disseminação científica: intra-pares, entre pesquisadores da mesma área e extra-pares, entre indivíduos que partilham a atividade científica em qualquer área. Levando em conta o grau de especialização dos cientistas nas diferentes áreas do conhecimento, os demais membros da comunidade científica podem ser considerados leigos também.

Retomando, em meio a este panorama, a DC configura-se como parte da cultura científica e é através dela que se torna possível a conquista da ciência por indivíduos que não estão diretamente ligados à produção, difusão ou ao processo de ensino e aprendizagem em torno da mesma. Por meio da DC é que se dá “a participação ativa do cidadão nesse amplo e dinâmico processo cultural em que a ciência e a tecnologia entram cada vez mais em nosso cotidiano” (Vogt, 2006, p.25) 
A cultura científica, neste contexto, é entendida como cultura para a Ciência e protagoniza uma dinâmica que Vogt visualiza um movimento em espiral. O ponto de partida seria a produção e difusão científica, processos que tomariam lugar nas universidades, centros de pesquisa, instituições voltadas para a pesquisa, entres outros. A espiral segue rumo ao segundo quadrante que engloba o ensino da ciência e a formação dos cientistas e pesquisadores. Novamente, a Universidade, bem como as instituições educacionais, configuram cenário para este tipo de transmissão de saber. No terceiro quadrante há o conjunto de processos que levam ao ensino para a ciência. Somente no quarto quadrante há a divulgação da ciência em si. Ou seja, a DC é apenas parte do percurso de evolução das atividades e práticas científicas.

Até o momento, verificou-se que a DC vem sendo considerada parte de um processo complexo chamado cultura científica. Além disso, observou-se que a DC pressupõe o JC, mas o contrário não ocorre, pois a DC engloba outras práticas de divulgação que não as jornalísticas, em outros meios, como os museus, por exemplo. Neste momento, a DC será vista sob a perspectiva da linguagem.

\subsection{DC e linguagem}

A DC levanta algumas problemáticas não somente quanto a sua função social e sua definição em face aos processos acima traçados. Sobretudo no que diz respeito à linguagem, há deferentes perspectivas em relação a como o discurso de divulgação científica é constituído.

Serão levantadas e debatidas as propostas de alguns autores como AuthierRevuz e Zamboni, bem como os quadros teóricos de autores da AD e finalmente, sendo esta pesquisa fundamentada pelo círculo de Bakhtin, as elucidações teóricas propostas em suas obras.

\subsubsection{A proposta de Authier-Revuz}

Authier-Revuz, em seu texto A encenação da comunicação no discurso de divulgação científica (1998), afirma que “a divulgação científica (...) é classicamente considerada como uma atividade de disseminação, em direção ao 
exterior, de conhecimentos científicos já produzidos e em circulação no interior de uma comunidade mais restrita (...)” (p.107).

A autora considera que o objetivo da DC é o de disseminar o conhecimento científico produzido no interior de uma comunidade restrita em direção ao exterior. O exterior a que a autora se refere é representado pela grande massa, pelo vasto público leigo em relação aos assuntos da ciência. Para seu maior desenvolvimento é necessário que a ciência dissemine as informações geradas em seu âmbito para que haja maior democratização do conhecimento, como citado anteriormente.

Para Authier-Revuz, a DC seria uma "prática de reformulação de um discurso-fonte (D1) em um discurso-segundo (D2)” (p.108). Logo, segundo esta autora, a DC é uma prática de reformulação sendo que seu funcionamento, ao contrário do que pressupõe uma tradução, seria o de um “discurso de reformulação explícita” por meio do quadro de dupla enunciação.

Essa dupla estruturação da enunciação compreende os interlocutores e o quadro de enunciação do discurso científico (D1) e os interlocutores e o quadro de enunciação do discurso da DC (D2). A DC, portanto, “organiza uma encenação dupla da atividade enunciativa: ela mostra o discurso científico no momento em que ele se diz, ao mesmo tempo em que se mostra no momento mesmo de transmiti-lo” (p.123).

A partir desta análise, pode-se considerar a DC como um discurso heterogêneo em que o plurilingüismo está presente. Authier-Revuz termina seu artigo afirmando que a DC é, portanto, um discurso "aproximativo, heterogêneo, dialógico" e que "esse discurso é também o lugar em que se celebra ausente, um discurso absoluto, homogêneo, monológico, de que ele próprio é só mais uma imagem degradada” (p.125).

Apoiando-se na proposta de Authier-Revuz, Moirand (2000) aponta para a questão da heterogeneidade no discurso de DC. Segunda a autora, o discurso de DC é formado por rupturas discursivas que

misturam o fio dos discursos de informação, constituem pontos de heterogeneidade a se estudar, e se a atividade de reformulação é com evidência constitutiva de qualquer discurso segundo, é a exibição dessa heterogeneidade que se mostra característica desse encontro das ciências com a mídia. 
Ao analisar a reformulação de um termo mesmo científico em diversos textos publicados sobre o fenômeno da vaca-louca em 1996, a autora afirma que a didaticidade com que o assunto, bem como os termos científicos, foram tratados, revela a existência de outros discursos implícitos no processo de reformulação do discurso-fonte.

\subsubsection{A proposta de Zamboni}

Zamboni (2001) é outra autora que se baseia na análise de Authier-Revuz para formular sua proposta acerca do discurso de DC. No livro de Zamboni, Cientistas, jornalistas e a divulgação científica (2001), a autora apresenta uma visão crítica em relação a Authier (1982) e faz ressalvas à afirmação de que a divulgação científica é "resultado de um efetivo trabalho de formulação discursiva, no qual se revela uma ação comunicativa que parte de um 'outro' discurso [o científico] e se dirige para ‘outro’ destinatário [o público leigo]”.

Para Zamboni (1997) o discurso de divulgação científica representa um gênero específico de discurso, que difere do campo do gênero do discurso científico. Ou seja, a autora não considera a DC como uma atividade de reformulação de um discurso a outro, mas sim, como uma atividade de formulação de um terceiro discurso.

A principal questão para se considerar a DC como um gênero discursivo próprio está presente no pólo da recepção: o leitor da DC é diferente do leitor do discurso científico, sendo que seus emissores podem ser os mesmos.

Outro fator que a diferencia de a Authier-Revuz aparece quando esta diz que a DC mostra o discurso-fonte ("os parâmetros do ato de enunciação de D1 estão presentes nos textos de D2, mostrando mais uma vez que D2 engloba D1 e sua enunciação”). De acordo com Zamboni, “a enunciação do discurso de outrem é tema recorrente nos mais diferentes gêneros discursivos e tipologias textuais”.

Logo, para Zamboni, o discurso científico entra na enunciação da DC, mas não é mais o D1 que, ao ser reformulado, vai originar um D2, como sugere Authier-Revuz.

Apesar de não sustentar a idéia de que a DC constitui um discurso reformulado ou traduzido do discurso-fonte que seria o científico, a análise de Zamboni de que a DC formula um novo discurso não se sustenta no momento em que a considera um gênero discursivo. 
(...) a divulgação científica constitui um gênero particular no conjunto dos demais discursos das diferentes áreas de funcionamento da linguagem, sujeito, portanto, a condições de produção bastante diversas daquelas que cercam, ao menos, o discurso científico. (2001, p.81).

Considerando a noção de gêneros discursivos, tal como proposta pelo Círculo, tem-se que eles pertencem a diferentes esferas da atividade humana. O discurso de DC é constituído em diferentes esferas, que não somente a científica. Ou seja, enquanto discurso a DC não está no plano dos gêneros, sendo constituída de diversos gêneros discursivos.

\subsubsection{A contribuição do Círculo}

Perante as análises com alguns aspectos questionáveis de Authier-Revuz e Zamboni, autoras que se apóiam nas noções bakhtinianas, e estando esta pesquisa inserida no mesmo quadro teórico, a DC será aqui considerada no âmbito das categorias conceituais do Círculo.

Baseando-se na teoria do Círculo, compreende-se que a ciência, o jornalismo e o universo escolar constituem esferas que permeiam o discurso de DC. Logo, a DC pode ser considerada uma prática discursiva que transita entre diferentes esferas, o que reforça a distinção feita por Bueno entre as diferentes formas de divulgação.

Em Os gêneros do discurso, Bakhtin chega a discorrer sobre os diferentes destinatários referentes a essas esferas.

\footnotetext{
os gêneros da literatura popular científica são endereçados a um determinado círculo de leitores dotados de um determinado fundo aperceptível de compreensão responsiva; a outro leitor, está endereçada uma leitura didática especial e ao outro, inteiramente diferente, trabalhos especiais de pesquisa. Em todos esses casos, a consideração do destinatário (e do seu fundo aperceptível) e a sua influência sobre a construção do enunciado são muito simples. Tudo se resume ao volume dos seus conhecimentos especiais. (Bakhtin, 2003/1979, p. 302)
}

Ao contrário do que diz Zamboni, de que a DC se trata de um gênero discursivo específico, pode-se dizer, segundo a teoria do Círculo, que a DC se vale de diferentes gêneros discursivos, tais como artigo, reportagem, entrevista, 
entre outros, para compor o seu discurso. É sob este foco teórico que esta pesquisa se apoiará.

\subsection{DC na Internet: problemáticas e perspectivas}

O advento da internet proporcionou mudanças sem precedentes para a prática da DC. A consulta aos dados tornou-se mais acessível, levando os jornalistas e divulgadores da ciência às inúmeras possibilidades de fontes científicas. Ao contrário do que costumava acontecer, o pequeno número de fontes que dominavam o cenário da DC, agora, abriram espaço para a busca frenética por informações da esfera científica.

No entanto, assim como questiona Macedo-Rouet (2002), faz-se necessário refletir o quão confiáveis são essas fontes e qual o verdadeiro papel da internet na prática da DC.

Com o aumento das fontes e a infinidade de possibilidades de referências da esfera científica, a DC tem corrido perigos no que diz respeito á credibilidade do tipo de informação que tem sido veiculada. Corre-se o risco de utilizar uma grande quantidade e variedade de dados, sem uma fundamentação científica correta e sólida. A falta de informações a respeito dos pesquisadores responsáveis pelos estudos citados e a não demonstração dos procedimentos adotados, têm ferido a credibilidade das fontes utilizadas na DC. Geralmente, as informações atribuídas à internet chegam são questionadas quanto ao seu grau de veracidade e relevância.

Um terceiro fator problemático decorrente da má formulação de hipertextos trata da dificuldade de o leitor usuário ter acesso às informações, bem como avaliá-las de acordo. Segundo Macedo-Rouet (2002),

a multiplicidade de fontes que a web oferece representa uma dificuldade para os usuários, quando eles têm de avaliar e selecionar as informações. Leitores de divulgação científica não são como pesquisadores buscando informações específicas, dentro de uma área de conhecimento bem delimitada e munidos das técnicas e métodos apropriados. (p.2)

Uma vez tendo levantado algumas questões emblemáticas para a prática da DC na internet, Macedo-Rouet apresenta a concepção de mapping science journalism, idealizada pelo professor Brian Trench. Trata-se de uma nova forma 
de se fazer jornalismo na Internet. Ao invés de apresentar conteúdos de fontes duvidosas, ou simplesmente reproduzir informações dos sites fonte, o desafio para este tipo de prática jornalística, afirma Macedo-Rouet, é o de “transformar-se em um guia do leitor através do emaranhado de informações da web, oferecendo um mapa de fontes e links apropriados para uma boa navegação”. Mesmo porque, tanto o profissional quanto o leitor usuário comum da rede possuem igual acessibilidade às informações. Logo, cabe ao jornalista e ao divulgador da ciência, organizar uma leitura interessante e confiável ao seu leitor.

A questão dos usuários da web é debatida pela autora em outro artigo. Nele, Macedo (2003), aponta que “os principais determinantes desse uso são o grau de escolaridade e de cultura científica (civic scientific literacy) dos indivíduos” (p.124). Ou seja, a recepção da DC na internet está relacionada a dois fatores importantes: primeiro à familiarização e letramento do individuo quanto à tecnologia e uso do computador e seus programas; em segundo lugar ao quanto o indivíduo está inserido no processo de cultura científica.

Perante as questões levantadas, esta pesquisa toma para si algumas definições acerca da DC. Em contraposição à noção de reformulação de um discurso-fonte, tal como sugere Authier-Revuz, ou de DC como um gênero específico de acordo com Zamboni, é assumida a concepção bakhtiniana de esfera. Primordialmente, considera a DC como uma prática discursiva que transita entre diferentes esferas de atividade humana, como a científica e a jornalística, e que participa do complexo processo de produção e circulação da ciência que Vogt (2006) denomina cultura científica. Tendo em vista os posicionamentos adotados até então, segue-se a análise do corpus. 


\section{Capítulo 5}

\section{Artigo e reportagem: gêneros da divulgação científica na internet}

Os dossiês da revista Com Ciência são formados por um conjunto de textos dos gêneros discursivos editorial, reportagem e artigo, que tratam de assuntos da esfera científica. Antes da análise das relações dialógicas hipertextuais entre os enunciados dados, esse capítulo tratará das questões estritamente relacionadas aos gêneros artigo e reportagem presentes no corpus.

Primeiramente, propõe-se uma discussão mais abrangente em relação ao estatuto dos gêneros na internet. Apesar de terem assimilado os recursos da mídia em questão, esses gêneros mantêm aspectos de suas categorias constituintes, ou seja, estilo, forma composicional e conteúdo temático, que se assemelham a artigos e reportagens presentes em outras mídias, como a impressa. Logo, interessa saber o que faz com que tais gêneros possam ser denominados gêneros digitais. Finalmente, a segunda parte do capítulo trará um estudo comparativo dos elementos constituintes dos gêneros artigo e reportagem.

\subsection{O gênero discursivo na Internet: digital ou hipertextual?}

Ao lado de gêneros que não só se apropriaram, mas também potencializaram a tecnologia da informática, como e-mail, blog, etc, como classificar os gêneros artigos e reportagens da Com Ciência, uma vez que preservam características de gêneros da mídia impressa?

Considerar-se-á que, mesmo ocorrendo em veículos de comunicação impressos artigo e reportagem tornam-se gêneros digitais no ambiente eletrônico. A diferença entre artigos e reportagens impressas e digitais está exatamente na tecnologia utilizada que oferece, aos gêneros digitais, possibilidades específicas para que eles se desenvolvam.

Todo conteúdo armazenado e processado em um computador é considerado digitalizado. Isto ocorre uma vez que sua codificação depende de dígitos, ou seja, números. Levy (1999) afirma que “digitalizar uma informação consiste em traduzi- 
la em números”. Por isso os artigos e reportagens da Com Ciência podem ser considerados digitais.

No entanto, alguns autores, como Araújo (2004), preferem fazer uso do termo gênero hipertextual para designar o conjunto de gêneros do discurso que ocorrem em ambiente digital. Neste momento, é preciso voltar à definição de hipertexto. $\mathrm{O}$ hipertexto digital é não somente uma tecnologia de articulação de conteúdos na rede, mas também um verdadeiro mecanismo que é capaz de potencializar as formas de dialogismo entre enunciados.

Há alguns exemplos que revelam que a hipertextualidade também ocorre em outros tipos de suporte, que não o computador: romances, como o Jogo da amarelinha de Julio Cortazar; notas de rodapé em um artigo ou texto científico, que remetem a outros enunciados no texto ou fora dele. O hipertexto é uma forma de remissão a outros textos em dimensão ampla, sendo não uma categoria de gêneros, mas uma prática textual. Marcuschi (2004) partilha da mesma opinião ao dizer que “também o hipertexto não pode ser tratado como um gênero e sim como um modo de produção textual que pode estender-se a todos os gêneros, dando-lhes neste caso algumas propriedades específicas” (p. 26).

Ao chamar os gêneros digitais de hipertextuais, faz-se necessário rever a definição do que seja hipertexto. Uma vez considerando que o hipertexto também ocorre em outros veículos, outros enunciados, com o mesmo tipo de organização textual, os gêneros aos quais pertencem também teriam de ser chamados de hipertextuais. Ou seja, tal como os digitais, todos esses outros gêneros discursivos deveriam ser denominados hipertextuais.

Apesar de o termo "hipertexto" ter advindo da tecnologia da internet, reconhece-se a existência desta organização textual em outros veículos. Logo, se atribuir aos gêneros digitais a denominação hipertextual não é problemática a partir do ponto em que seus enunciados comportam elementos da hipertextualidade, por outro lado, não se pode descartar que outros gêneros que não os digitais possuam caráter hipertextual. Logo, a categoria dos gêneros hipertextuais deveria abarcar todos os gêneros discursivos com esta mesma característica.

O hipertexto não deve ser reduzido à idéia de uma estrutura digital para comportar e movimentar conteúdos na rede mundial de computadores. No entanto, sua forma de articular os enunciados no suporte digital nos chama a atenção devido ao seu mecanismo tecnológico. 
Portanto, os gêneros artigo e reportagem na Internet serão considerados aqui gêneros digitais. Tais gêneros preservam as características de suas categorias constituintes, estilo, conteúdo temático e forma composicional, da mídia impressa, ao mesmo tempo em que utilizam os recursos da tecnologia digital, como links eletrônicos, hipertexto digital, sons e imagens.

Os aspectos relacionados à tecnologia não distanciam os artigos e reportagens digitais do site Com Ciência dos impressos. Sobretudo, com o passar do tempo, vêse que, nos dossiês, esses gêneros vêm mantendo, cada vez mais, as características ligadas aos seus elementos constituintes. Na segunda etapa desta análise, verificarse-á, de modo comparativo, o funcionamento das categorias constituintes dos gêneros artigo e reportagem digital.

\subsection{Artigo e reportagem digital: um estudo comparativo}

Os gêneros artigo e reportagem, embora digitalizados, preservam características semelhantes das que possuem em outro tipo de meio, como o impresso. Apesar da velocidade com que a tecnologia computacional se desenvolve e modifica aspectos da linguagem, esses gêneros mantêm as suas características estilísticas, composicionais, bem como preservam o tema destes tipos de enunciados.

A internet não deslocou o caráter opinativo mais explícito dos artigos, ou mesmo o caráter informacional também explícito das reportagens. Entretanto, a internet potencializa, por meio de sua tecnologia, certos aspectos que podem ser explorados ou revelados no âmbito dos gêneros discursivos artigo e reportagem encontrados no corpus.

Nos diferentes anos escolhidos para análise, sobretudo em relação ao ano 2000, há diferença na maneira de o site apresenta e elabora esses gêneros. No caso dos gêneros discursivos aqui analisados, o meio possui uma variável importante que diferencia o hipertexto digital dos demais e que o torna um elemento vital para a construção de sentido, o link eletrônico. Logo, buscaremos entender de que forma esse aspecto interage com os elementos constitutivos dos artigos e reportagens dos dossiês, bem como o comportamento desses gêneros em relação à internet. 
Do ponto de vista da forma composicional, a categoria selecionada para observação são os links eletrônicos, elementos da tecnologia que diferem artigos e reportagens digitais dos impressos.

De forma geral, no dossiê Clonagem (2002), há uma diminuição significativa dos links em relação aos outros dossiês. No entanto, o fator mais importante que se pode observar, implicado pela diacronia dos dados, é o aumento de links em cada artigo, uma vez que passam a ser publicados com maior incidência. Em 2000 há poucos artigos e somente um deles possui hiperlink, se compararmos ao dossiê de 2004.

Aparecendo com mais freqüência nos artigos em 2002 e 2004, o link deixou de lado o caráter primordialmente organizacional que possui na primeira etapa dos dossiês (como forma de seqüenciação textual, por exemplo) para fortalecer a construção de sentido estabelecida no diálogo com sujeitos individuais e institucionais da esfera da ciência. Há um aumento de links que remetem a termos especializados, o que fortalece o diálogo com a esfera científica.

As tabelas 4, 5 e 6 contemplam as categorias e a quantidade de vezes que os links ocorrem em cada ano, especificamente nos gêneros artigo e reportagem.

Tabela 4

\begin{tabular}{|c|c|c|c|c|c|}
\hline \multicolumn{6}{|c|}{ Remissão a enunciados do mesmo dossiê } \\
\hline \multicolumn{6}{|c|}{2000} \\
\hline $\begin{array}{l}\text { Gênero } \\
\text { discursivo }\end{array}$ & $\begin{array}{l}\text { Títulos e } \\
\text { subtítulos }\end{array}$ & $\begin{array}{l}\text { Notas de } \\
\text { rodapé }\end{array}$ & $\begin{array}{l}\text { Termo } \\
\text { científico }\end{array}$ & $\begin{array}{l}\text { Assinatura dos } \\
\text { autores }\end{array}$ & $\begin{array}{l}\text { Indicadores } \\
\text { de seqüência }\end{array}$ \\
\hline Artigo & 3 & 0 & C & 0 & 0 \\
\hline Reportagem & 14 & 0 & 9 & 0 & 9 \\
\hline \multicolumn{6}{|c|}{2002} \\
\hline Artigo & 5 & 0 & C & 0 & 0 \\
\hline Reportagem & 10 & 0 & 5 & 0 & 0 \\
\hline \multicolumn{6}{|c|}{2004} \\
\hline Artigo & 5 & 11 & C & 0 & 0 \\
\hline Reportagem & 10 & 0 & 5 & 0 & 0 \\
\hline
\end{tabular}


Tabela 5

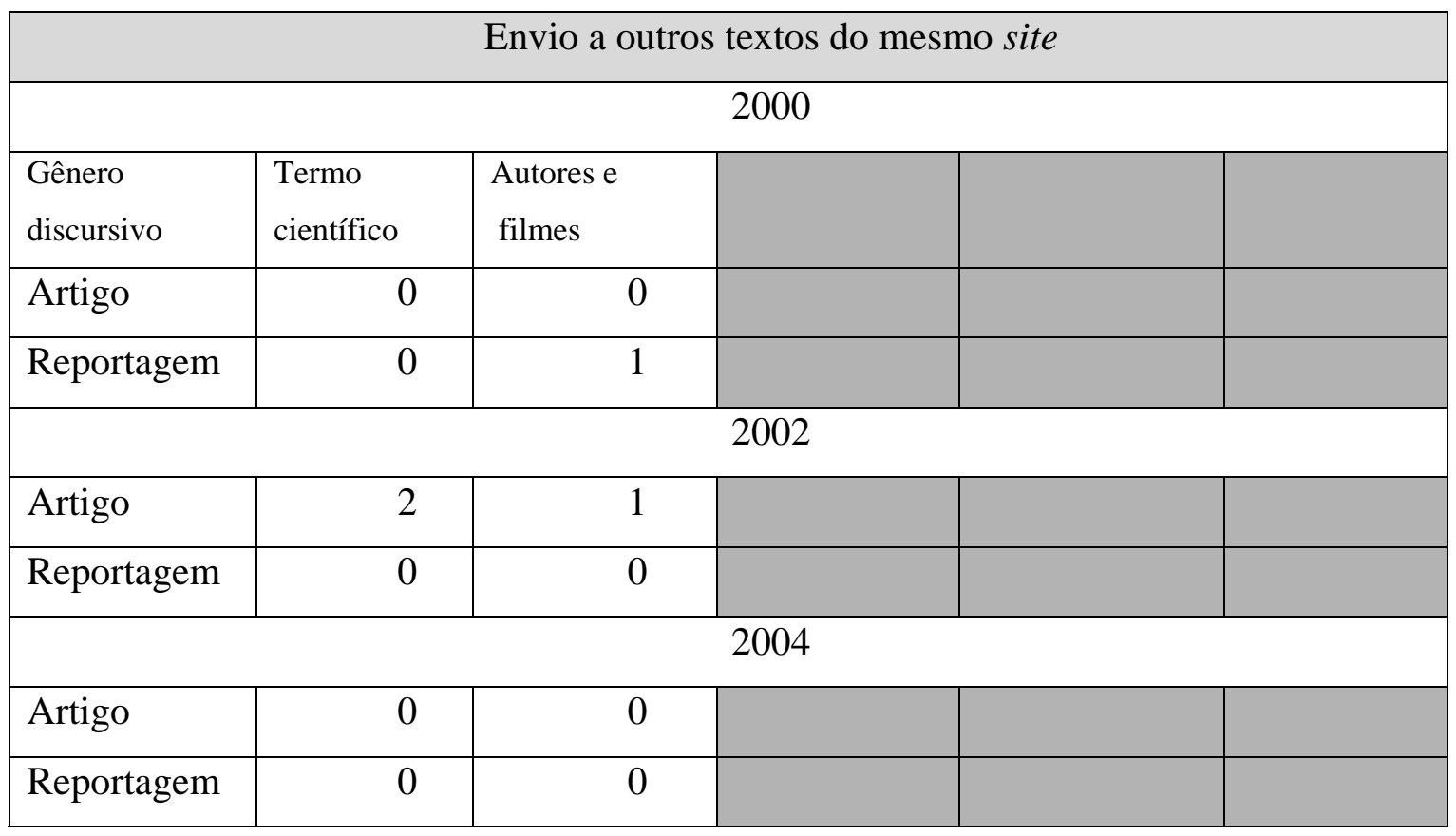

Tabela 6

\begin{tabular}{|c|c|c|c|c|c|}
\hline \multicolumn{6}{|c|}{ Envio a textos de sites externos } \\
\hline \multicolumn{6}{|c|}{2000} \\
\hline $\begin{array}{l}\text { Gênero } \\
\text { discursivo }\end{array}$ & Publicações & $\begin{array}{l}\text { Termo } \\
\text { científico }\end{array}$ & Autores & Instituições & Outros Sites \\
\hline Artigo & 0 & 0 & 3 & 0 & 0 \\
\hline Reportagem & 0 & 0 & 0 & 15 & 0 \\
\hline \multicolumn{6}{|c|}{2002} \\
\hline Artigo & 1 & 0 & 0 & 0 & 1 \\
\hline Reportagem & 9 & 9 & 1 & 12 & 2 \\
\hline \multicolumn{6}{|c|}{2004} \\
\hline Artigo & 0 & 0 & 0 & 0 & 0 \\
\hline Reportagem & 1 & 9 & 0 & 6 & 1 \\
\hline
\end{tabular}

Inicialmente, percebemos que, ao longo dos anos 2000 e 2004, há uma oscilação em relação ao aspecto quantitativo de links que remetem a textos internos de cada dossiê. 
Na série sobre Energia Nuclear (2000), os gêneros resumem-se a artigo e reportagem. O índice não designa, como nos anos seguintes, as seções do dossiê, sendo, portanto, mais difícil de distingui-los, guiando-se apenas pelo sumário. Por um lado, os artigos, cuja ocorrência é pequena, trazem as assinaturas e opiniões de especialistas da área em questão, por outro, as reportagens contam com figuras autoexplicativas, maior incidência de links, maior índice de dados históricos e numéricos.

O dossiê Energia Nuclear é ainda caracterizado por uma seqüência textual diferente da dos demais. No final de cada reportagem e artigo, há links que funcionam como passagem para o texto da próxima página, isto é, como uma forma de seqüenciação dos textos como em (3), (4) e (5).

(3) Outro sinal da confusa política nuclear brasileira é a indefinição quanto ao destino dos resíduos radioativos...

(4) Um dado importante é o crescimento da utilização de energia nuclear no mundo, nas últimas décadas...

(5) Todas essas considerações voltam a ser objeto de debate no Brasil com a inauguração de Angra $2 \ldots{ }^{14}$

O texto seguinte tratará exatamente dos 'resíduos radioativos', com que terminou o enunciado anterior. Este dossiê apresenta uma série de textos, sobretudo no gênero reportagem, que parecem formar um grande e único enunciado dividido pelas páginas eletrônicas, títulos e subtítulos. Essa estratégia de seqüenciação não é adotada pelos outros dossiês, cujos gêneros discursivos são bem delimitados e separados por um sumário auto-explicativo. Nos demais dossiês, o texto é mais perceptível do ponto de vista do gênero, no que diz respeito a seu conteúdo temático, composicional e estilístico.

Os artigos tendem a exibir mais links, em 2002, que remetem a outros gêneros do dossiê (resenha e notícia), nome de filme, títulos de publicação e expressões em geral. No último dossiê analisado, há uma novidade, notas de rodapé, fator que

${ }^{14}$ Fragmentos retirados do dossiê sobre Energia nuclear (2000). 
demonstra uma especialização da utilização dos recursos digitais para facilitar a recepção do gênero em questão.

Contudo, a incidência de hiperlink no gênero reportagem é esmagadoramente maior em relação aos artigos. Dentre as ocorrências, eliminando o próprio título das reportagens que estão sob forma de link eletrônico, destacam-se expressões científicas, nome de autores e de instituições em geral. A partir de 2002, incluem-se títulos de publicações externas ao site Com Ciência.

Quando o hiperlink nos remete a sites externos que pertencem à esfera estritamente científica, o hipertexto parece constituir um diálogo com esta esfera e dar voz ao campo da ciência. Neste caso, o respaldo científico ou a referência de outras esferas como a política (como revela a menção ao Greenpeace) seria dado não somente pela voz do cientista, mas também pela instituição cujo site está ali sob forma de link, como podemos ver no fragmento em (6) e em (7):

(6) Um dos principais argumentos utilizados pelos defensores das usinas nucleares é o seu baixo nível de poluição do ambiente. Segundo eles, a usina nuclear seria capaz de produzir energia elétrica "limpa". Esta, entretanto, não costuma ser a opinião das organizações de defesa do meio ambiente, como o Greenpeace. ${ }^{15}$

(7) Rudolf Jaenisch do Instituto Whitehead para Pesquisa Biomédica tem sido um feroz crítico dos esforços correntes em clonagem humana, incluindo os de Zavos. ${ }^{16}$

(8) Segundo a The Scientist um ano após a decisão de Bush, nem todos os pesquisadores estavam conseguindo acesso às linhagens de célulastronco embrionárias para o financiamento público de seus

\footnotetext{
${ }^{15}$ Extraído da reportagem $O$ tratamento dado aos rejeitos radioativos, do dossiê sobre Energia nuclear (2000).

${ }^{16}$ Extraído da reportagem Políticos tentam regulamentar mundialmente a clonagem, do dossiê sobre Clonagem (2002).
} 
experimentos e os investimentos na área eram poucos, devido às incertezas legais e políticas em torno do assunto. ${ }^{17}$

A presença de links externos, que remetem a títulos de publicações, expressões científicas, nome de autores e instituições, é grande em todos os dossiês e ocorre com maior incidência no gênero reportagem. Em 2000, há apenas remissão a autores e instituições. Ao longo do tempo, o envio a sites institucionais diminui bastante e o envio a nomes de autores desaparece. No entanto, é crescente a utilização do hiperlink sob forma de expressão científica que remete a sites externos.

Ao contrário da reportagem, que muitas vezes nem é assinada pelo autor, o gênero artigo é mais propício ao estilo individual No fragmento do artigo Transformações da energia remetem à origem do Universo em (9), o autor utiliza uma linguagem mais poética para descrever a ocorrência da produção de energia pelos elementos da natureza, o que foge do caráter mais supostamente objetivo da reportagem. O estilo individual pode ser identificado pela escolha lexical feita pelo autor ao atrelar os verbos ‘encrespar’ e ‘varrer’ a elementos da natureza.

(9) Os ventos encrespam as águas do mar e formam ondas que varrem praias e costões rochosos num movimento incessante. É possível retirar energia das correntes marinhas e das ondas e, no futuro, certamente faremos isso melhor que agora. ${ }^{18}$

Enquanto isso, nas reportagens, vê-se o uso abundante de dados históricos, estatísticos e links eletrônicos para a explicação de termos e fatos.

(10) De certa maneira, surgiu uma intranqüilidade desde que a ovelha clonada Dolly foi apresentada há alguns anos atrás. Em janeiro de 1998, como resposta à Dolly, o Council of Europe (COE) delineou um Protocolo (Protocol on Prohibition of Cloning Human Beings) sobre a proibição de clonar seres humanos como parte da existente

17 Extraído da reportagem Há controvérsia no financiamento nos EUA, do dossiê sobre Células-tronco (2004).

18 Extraído do artigo Transformações da energia remetem à origem do Universo, por Ulisses Capozolli, do dossiê sobre Energia nuclear (2000). 
Convenção Européia sobre direitos humanos e biomedicina (Convention on Human Rights and Biomedicine). ${ }^{19}$

A utilização dos links eletrônicos constitui um aspecto da forma composicional desses gêneros, mas que, ao mesmo tempo, reflete o conteúdo temático de cada um. Mesmo depois do aumento significativo de links eletrônicos em artigos, este gênero parece não comportar o link da mesma forma com que o gênero reportagem. Isto pode ocorrer pelo fato de o artigo ser mais claramente autoral e, por conta disso, demarcar uma opinião, o que pode tornar as remissões exteriores ao site uma alternativa conflituosa para a idéia desenvolvida pelo autor.

A questão autoral torna-se ainda mais evidente nos dossiês sobre Clonagem (2002) e Células-Tronco (2004), já que há maior detalhamento do perfil de quem escreve, como em (11), o que delimita quais sujeitos pertencem à esfera científica e quais à esfera jornalística.

(11) Luís Henrique Wolff Gowdak é ex-fellow Gene Therapy Unit, Laboratory of Cardiovascular Science, National Institutes of Health, Estados Unidos - Doutor em Cardiologia pela Faculdade de Medicina da USP - Médico-Assistente do Laboratório de Genética e Cardiologia Molecular e da Unidade Clínica de Coronariopatias Crônicas do Instituto do Coração (InCor) do Hospital das Clínicas da Faculdade de Medicina da USP. ${ }^{20}$

Nos artigos, em (12) e (13), os autores aparecem no enunciado assumindo posicionamentos a respeito dos assuntos discutidos, respectivamente, clonagem e células-tronco.

(12) Se eu tivesse que dar um nome para essa técnica eu diria que ela é apenas mais uma dentre as diferentes técnicas de fertilização

\footnotetext{
19 Extraído da reportagem Políticos tentam regulamentar mundialmente a clonagem, do dossiê sobre Clonagem (2002).

${ }^{20}$ Extraído do artigo Terapia celular em cardiologia, do dossiê sobre Células-tronco (2004).
} 
assistida, que procura unir uma célula sexual feminina enucleada com uma célula somática, isto é, uma célula não-sexual. A meu ver, a única e grande restrição que deve ser feita, no momento, à aplicação dessa técnica à espécie humana reside no fato de que, até agora, os resultados conseguidos com ela em outros mamíferos ainda estão longe de serem considerados bons. ${ }^{21}$

(13) Gostaria de enfatizar que as células-tronco autólogas (do próprio indivíduo) de qualquer fonte não curam as doenças, pois não corrigem as causas da doença seja ela infecciosa, ambiental ou genética. ${ }^{22}$

Quando levanta idéias contrárias, o artigo o faz com o mesmo objetivo, constituir um pensamento, mas, desta vez, por oposição àquilo que não se julga ser coerente. Ou seja, o aproveitamento dos links está diretamente relacionado com o posicionamento editorial da revista em torno do assunto da esfera científica que está tratando e na maneira com que cada gênero irá apresentar-se quanto aos elementos constituintes. No caso dos artigos, em que a voz do autor é mais explícita, procurase abafar as vozes externas ao site e as remissões contribuem para que as idéias do autor sejam ressaltadas.

Neste capítulo, buscou-se compreender de que forma os gêneros digitais artigos e reportagens do site Com Ciência são constituídos. Considerando que a tecnologia de armazenamento e produção de informações da internet é baseada na codificação de dígitos, entende-se, por gênero digital, todo aquele que circula na internet enquanto espaço de comunicação, assim como postula Levy (1999), e apropria-se de recursos próprios desse meio, como o link eletrônico.

Primeiramente, os gêneros discursivos na internet assumiram as características dos gêneros impressos. Atualmente, os gêneros digitais vêm assimilando os recursos tecnológicos desta mídia. No entanto, apesar de fazerem aproveitamento diferente dos recursos da internet, principalmente dos links

\footnotetext{
${ }^{21}$ Extraído do artigo Nada contra a clonagem, por Bernardo Beiguelman, do dossiê sobre Clonagem (2002).

${ }^{22}$ Extraído do artigo Célula-tronco é promessa para medicina do futuro, por Antonio Carlos Campos de Carvalho, do dossiê sobre Células-tronco (2004).
} 
eletrônicos, os artigos e reportagens do Com Ciência parecem manter suas categorias constituintes, estilo, tema e forma composicional, da maneira que elas ocorrem em enunciados da mídia impressa.

Sob o ponto de vista da forma composicional, o uso de links eletrônicos ocorre, com maior incidência, em reportagens que em artigos. Apesar do aumento do número de artigos nos anos 2002 e 2004 e, conseqüentemente, do número de links nestes, o aproveitamento deste recurso é bem maior nas reportagens.

Em relação ao estilo, foi visto que o artigo é um gênero mais propenso à expressão do estilo individual do autor e recorre a um registro mais informal para obter maior aproximação do leitor aos assuntos da esfera científica. O conteúdo temático do artigo revela-se mais opinativo e passível de apresentar mais marcas de subjetividade.

Enquanto isso, as reportagens são menos propícias ao estilo individual, apagando as marcas de subjetividade de seus enunciados. Contam com mais dados históricos e estatísticos para fundamentar os posicionamentos apresentados nos dossiês. Quanto ao conteúdo temático, a reportagem tende ao caráter mais informativo e objetivo.

Diante de tais considerações sobre os gêneros artigo e reportagem, pode-se constatar que seus elementos constituintes estilo, forma composicional e conteúdo temático, mantêm as características encontradas em artigos e reportagens impressos no meio digital da internet. Pode-se considerar o uso do link eletrônico como uma novidade para a composição desses gêneros na internet, mas que não chega a gerar grandes mudanças para o estilo e o conteúdo temático dos mesmos. 


\section{Capítulo 6}

\section{O dialogismo hipertextual pelo link eletrônico}

O intuito principal deste capítulo é o de procurar evidenciar uma proposta dos diferentes níveis de relações dialógicas que leva em conta a relação hipertextual entre enunciados por meio desses nós eletrônicos. Este levantamento supõe uma análise preliminar do corpus.

No segundo momento deste capítulo, uma vez elencadas as diferentes relações dialógicas encontradas entre os enunciados, voltar-se-á aos dados do corpus em si, a fim de se verificar que tipos de relação semântico-axiológicas podem ser encontrados, bem como a produtividade das remissões estabelecidas via links eletrônicos nos diferentes anos e assuntos escolhidos para análise.

\section{1 Relações dialógicas hipertextuais: remissões entre enunciados}

Com o intuito de observar o processo dialógico entre os enunciados eletrônicos, elaborou-se um levantamento dos níveis de remissão dialógica hipertextual realizada pelos links eletrônicos, encontrados nos textos do corpus. Tal levantamento foi constituído a partir da observação da relação entre os enunciados presentes no hipertexto digital, interligados pelos nós eletrônicos. Há uma hipótese de que os diferentes planos de remissão serão produtivos para a análise das relações dialógicas.

Dessa forma, verificou-se que há três planos distintos em que ocorrem as remissões hipertextuais entre enunciados. Cada tipo de envio ou remissão será explorado mais detidamente, a seguir, a fim de que se possa compreender, com maior exatidão, o funcionamento do hipertexto digital e das relações dialógicas nele encontradas.

Os tipos de remissão foram delimitados de acordo com a ocorrência dos links eletrônicos encontrados e serão detalhados nos próximos itens:

(i) Remissão entre enunciados pertencentes aos dossiês que compõem as reportagens especiais mensais. Ou seja, dois enunciados interligados e que fazem parte de um mesmo dossiê; 
(ii) Remissão de enunciados do dossiê a textos de outras seções do site Com Ciência;

(iii) Remissão de enunciados do dossiê a enunciados de outros sites.

\subsubsection{Remissão entre enunciados internos ao dossiê}

O primeiro plano em que o dialogismo hipertextual está instaurado acontece entre enunciados dos gêneros discursivos presentes na mesma reportagem especial ou dossiê. Neste nível, todo nó eletrônico clicado dá acesso a outro enunciado que se relaciona a outros textos do dossiê.

O quadro abaixo representa a dinâmica do primeiro nível de remissão hipertextual que encontramos:

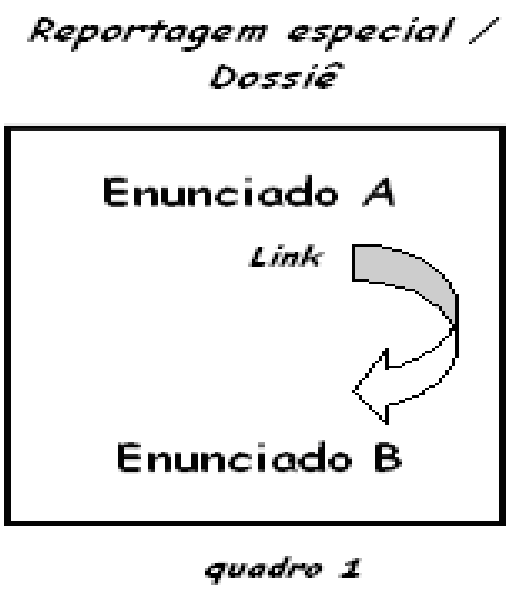

O link eletrônico, representado pela flecha no quadro 1, é o mecanismo responsável por fazer a ponte entre os enunciados A e B. Nesse processo de remissão entre enunciados, os links assumem formas de diferentes ordens lexicais. Tais formas podem ser divididas de acordo com as seguintes categorias: titulação, terminologia científica, terminologia de navegação do site, subtítulos, notas de rodapé e identificação dos autores.

A titulação ocorre quando os links eletrônicos assumem a forma de títulos dos textos no sumário do dossiê. Se clicados no sumário, esses títulos remetem ao respectivo texto. Sob forma de títulos, o link geralmente cumpre a função de sintetizar o conteúdo do texto seguinte, antecipando a polêmica, o debate, a explicação, ou outra função que o enunciado propõe apresentar. 
Os links eletrônicos desse tipo encontrados no corpus do trabalho foram selecionados de acordo com sua ocorrência em cada dossiê, respectivamente, Energia Nuclear, Clonagem e Células-Tronco.

- Energia Nuclear: reacende o debate, Mapa mundial, Custos de produção, Em funcionamento, Monitoração ambiental, Cracas $e$ tubulações, Plano de emergência, $\underline{\text { História do projeto, Lixo nuclear, }}$ Duas opiniões sobre a energia nuclear no Brasil, Domando a energia nuclear, Clonagem ainda é técnica em desenvolvimento; $\underline{\text { Clonagem }}$ terapêutica ainda é promessa, Leis restringem pesquisas com célulastronco, Quem defende a clonagem humana, Polêmica também envolveu primeiro bebê de proveta, Clonagem humana é debatida por juízes brasileiros, Políticos tentam regulamentar mundialmente a clonagem, Clonagem já tem uso amplo na agropecuária, Técnica não é novidade na agricultura, Clonagem sob o olhar da religião, Nada contra a clonagem, clones na mídia, humanos ao amanhecer, $\underline{\text { Seres }}$ híbridos\& Clones: da literatura para as telas, das telas para a realidade, Pesquisa brasileira em CT já apresenta resultados, Em meio à discussão ética, a pesquisa avança em todo o mundo, Faltam leis, sobre polêmica, Há controvérsia no financiamento nos EUA, Brasil Cord favorece investimentos para bancos de sangue, Célulastronco desafiam a mídia, Células-tronco é promessa para medicina do futuro, $\underline{\text { Clonagem terapêutica...e polêmica, } \text { A propósito da utilização }}$ de células-tronco, Terapia celular em cardiologia, Células-tronco e câncer: vida e morte com origem comum?, Aplicações terapêuticas das células-tronco: perspectivas e desafios

Todos os itens lexicais referentes à esfera científica foram destinadas à categoria terminologia científica. Quando assim selecionados, os links estabelecem uma relação semântica explicativa ou exemplificativa, levando a definições e dados. Isso reflete o próprio propósito da DC, o de aproximar o leitor dos enunciados da esfera científica, a fim de que haja maior e melhor entendimento sobre o assunto.

Principalmente no gênero reportagem, esses itens são selecionados como link eletrônico para levar o leitor a um glossário explicativo dos termos que não lhe 
seriam familiares. No entanto, este tipo de seleção ocorre somente no primeiro dossiê, Energia Nuclear.

- combustíveis fósseis, descomissionamento, $\underline{\mathrm{MW} / \mathrm{h}}$, $\underline{\text { resíduos radioativos, }}$ nucleoeletricidade, processo de centrifugação, força nuclear forte

Este tipo de remissão também apresenta uma terminologia de navegação do site. Tais expressões reforçam a aproximação do leitor aos enunciados, indicando a navegação no próprio site e sinalizando ao usuário a sua forma de utilização.

- Tabela comparativa, Glossário, Filmes indicados, Veja artigo nesta edição, reportagem, voltar

Sob forma de subtítulos, os links, quando clicados, remetem o leitor ao início de um novo texto, funcionando como um elo entre um texto e outro. Aparecem no final de cada texto e selecionam os mesmos termos que iniciarão o próximo texto como link eletrônico. Mais uma vez, esta categoria de remissão dos links ocorre somente no dossiê sobre Energia Nuclear.

- energia nuclear no mundo, custos de produção da energia nuclear, inauguração de Angra 2, instalações, monitoração ambiental, áqua do mar, Plano de emergência, resíduos radioativos.

Os links eletrônicos também assumem a função de notas de rodapé, representados por meio de numeração, remetendo a informações adicionais ao final de cada texto. Os números correspondentes a cada nota funcionam como o nó que interliga os enunciados. Esta utilização só ocorre no último dossiê e estabelece relação de complementação do enunciado anterior, referenciação, ou mesmo explicação quando necessário.

A identificação dos autores ocorre por meio de suas iniciais ao final de cada texto.

$\bullet \underline{\mathrm{LZ}}, \underline{\mathrm{RC}}, \underline{\mathrm{MT}}, \underline{\mathrm{AZ}}, \underline{\mathrm{MK}}, \underline{\mathrm{JB}}, \underline{\mathrm{JS}}$ 
Tais assinaturas remetem à seção créditos, na qual também é possível, por meio dos nomes de cada autor, acessar os textos que ele escreveu, ou colaborou como co-autor. Assim como o item anterior, esta ocorrência aparece somente no dossiê sobre Células-tronco.

\subsubsection{Remissão a enunciados internos ao site}

O segundo nível de remissão dialógica hipertextual dá-se entre enunciados do site Com Ciência, sendo que o enunciado A pertence aos textos dos gêneros discursivos do dossiê e o enunciado B pertence a textos de gêneros discursivos presentes em outras seções do mesmo site. O quadro 2 apresenta uma perspectiva deste tipo de remissão hipertextual que se apresenta no segundo plano do levantamento traçado pela pesquisa:

Site Com Ciência

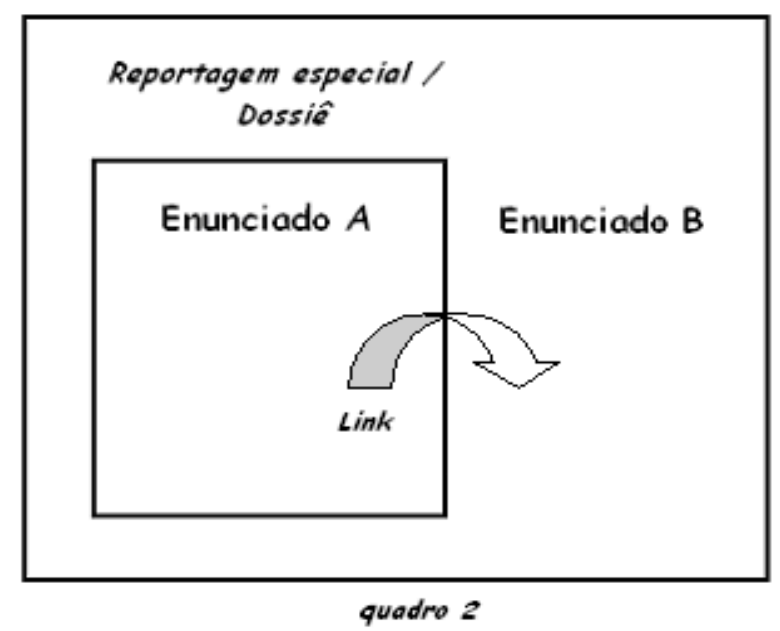

No corpus, a recorrência de remissão de enunciados a textos internos ao site Com Ciência, mas que não fazem parte dos dossiês, é pequena se comparada aos demais tipos de remissão encontrados. Em 2004, por exemplo, há apenas uma ocorrência deste tipo. Já nos demais anos em que os dossiês foram selecionados, os links eletrônicos indicam algum texto pertencente a outros gêneros discursivos e seções do site, tais como resenha e notícia. Os links encontrados podem ser 
categorizados da seguinte forma: nome de autor e terminologia de navegação do site. A seguir, uma breve descrição de cada uma delas:

Quando o nome do autor citado no corpo do texto está sob forma de um link eletrônico, este levará a algum outro texto, dentro do próprio site, que remete a alguma referência sobre ele, seja uma entrevista, resenha ou notícia envolvendo seu nome. O único exemplo encontrado foi encontrado no dossiê sobre Energia Nuclear.

\section{- Anselmo Paschoa}

A terminologia de navegação do site pressupõe links eletrônicos que auxiliam o usuário na navegação do site, mas, neste nível, apontam para itens que estão fora do dossiê temático, mas dentro de uma outra seção.

\section{- $\underline{r e s e n h a}^{\text {notícia }}, \underline{\text { Gattaca }}^{23}$}

Este tipo de remissão é mais produtivo nos dois últimos dossiês e aponta para uma possível estratégia editorial de não posicionar-se acerca dos assuntos tratados. Portanto, observa-se o aproveitamento do link para remissões a sites externos ou

\subsubsection{Remissão a enunciados externos ao site}

O terceiro nível de remissão dialógica delimitada na tipologia proposta diz respeito ao envio a enunciados externos, ou seja, enunciados que se encontram fora do site Com Ciência. Temos um enunciado A no interior do dossiê temático, cujo link eletrônico leva a um enunciado B localizado em outro site, tal como se verifica no quadro 3.

\footnotetext{
${ }^{23}$ Neste caso, o nome de algum filme é destacado sob forma de link eletrônico, a fim de remeter a alguma resenha crítica em outra seção da revista eletrônica.
} 


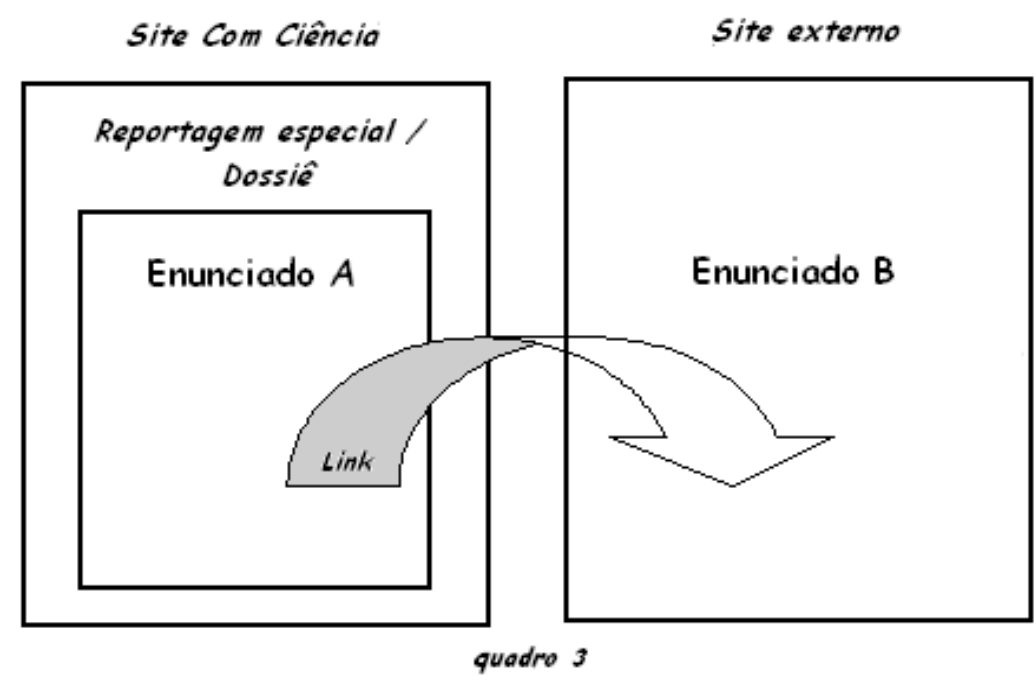

Os links eletrônicos que remetem a outros sites geralmente compreendem: títulos de publicações, terminologia de navegação do site, nome de autores e nome de instituições. Segue-se a descrição de cada uma dessas categorias:

Sob forma de títulos de publicações, os links eletrônicos remetem a artigos ou publicações disponibilizados em algum outro site, funcionando como fonte de referência bibliográfica. A utilização deste tipo de link favorece uma relação de complementação entre os enunciados A e B, uma vez que em B encontram-se questões mais aprofundadas do que foi tratado em A.

Esta categoria não é produtiva no primeiro dossiê, sendo que sua ocorrência é observada somente nos dois últimos.

- Theologians oppose human cloning but warn of dangers of a ban, $\underline{\mathrm{La}}$ course aux clones, The first human cloned embryo, $\underline{\text { Aconteceu, Virou }}$ Manchete, Manifesto contra a utilização de embriões humanos em pesquisa

Como se pode notar, a terminologia de navegação do site é pertinente a todos os níveis hipertextuais levantados. Tais expressões orientam os usuários nas navegações no interior do dossiê (no primeiro nível remissivo), no interior do site Com Ciência (no segundo nível remissivo), e, ainda, na busca de informações específicas em outros sites. A seguir, exemplos do dossiê sobre Clonagem e Células-tronco, respectivamente: 
- veja também a página de Tesarik, veja página pessoal, veja reportagem da Scientific American

Quando o nome de algum autor está atrelado a um site externo, pode-se encontrar uma citação em outro site, mas também referências mais gerais à pessoa em questão. Muitas vezes esse tipo de remissão é muito vago, ou seja, alguns links eletrônicos desta categoria, quando clicados, apontam apenas para a página principal de um site que possui alguma informação sobre o autor, mas esta deve ser procurada pelo usuário em alguma seção desse site.

- $\underline{\text { Panos Zavos, }}$ B.H. Ripin, Edwin Lyman, John D. Lawson.

A recorrência de nome de instituições como link eletrônico é abundante e remete a sites institucionais de forma geral ou que estão relacionados diretamente à esfera científica.

- Greenpeace, AIEA, Ciência Hoje, INB, Ipen, The Virtual Nuclear

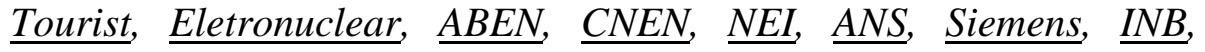
OCDE, Urenco.

Essas ocorrências estão em todos os dossiês temáticos, aparecendo com maior incidência no gênero reportagem. Em 2000, há apenas remissão a nome de autores e a nome de instituições. Ao longo do tempo, o envio a sites institucionais diminui bastante e o envio a nomes de autores chega a desaparecer. No entanto, é crescente a utilização do link eletrônico na forma de expressão científica que remete a sites externos ao Com Ciência.

\subsection{Análise dos níveis de remissão hipertextual em cada dossiê}

Este segundo momento da análise das relações dialógicas hipertextuais presentes no corpus, de acordo com o levantamento traçado, tem como objetivo aprofundar o estudo das relações estabelecidas pelos links eletrônicos presentes em cada dossiê temático. Nesta parte da análise, a questão central são as categorias funcionais dos links eletrônicos selecionados, conforme descritas nos itens 
anteriores, e o tipo de relação semântico-axiológica estabelecida entre os enunciados em conexão.

Os dossiês dos anos 2000, 2002 e 2004 abordam, como se disse, os seguintes assuntos: Energia Nuclear (em Energia Nuclear: custos de uma alternativa), Clonagem (em Clonagem: a dessacralização da vida) e Células-tronco (em Células-tronco). Lembramos que, na época de sua publicação, esses assuntos dos dossiês temáticos obtiveram certa repercussão em esferas da sociedade, que não a científica e foram alvo de notável debate e discussão em outras mídias e suportes.

Em cada dossiê, serão observados os três tipos de remissão hipertextual entre links eletrônicos referentes aos artigos e reportagens. Serão analisados os links eletrônicos e suas respectivas relações com os enunciados a que remetem.

\subsubsection{Energia Nuclear: custos de uma alternativa (2000) ${ }^{24}$}

No ano 2000, os dossiês temáticos publicados possuem uma estruturação pouco refinada em comparação com os demais anos de publicação. Seu sumário é mais simplificado e as reportagens resultam de um único texto fragmentado, dividido em diferentes páginas. Neste caso, os títulos, na verdade, correspondem a subtítulos, uma vez que os textos funcionam como fragmentos de um enunciado maior.

Esses aspectos das reportagens especiais desta fase podem ser explicados pelo pouco tempo de circulação da revista eletrônica, iniciada em 1999. Considerando o uso recente da internet, na época, para fins comerciais e pessoais, o site é pioneiro na área da divulgação científica na internet. Com o passar do tempo, novos aspectos vão garantir um estilo mais sofisticado a seus gêneros quanto à utilização dos recursos do suporte digital, na medida em que esta tecnologia vai sendo utilizada por eles e atualizada.

Nesse mesmo ano, os links eletrônicos são, em geral, utilizados em abundância, sendo encontrados em maior incidência em reportagens do que em artigos. Foram delimitadas as seguintes categorias, já desenvolvidas no item anterior, do link eletrônico no corpus relativo a este ano: titulação, terminologia científica, seqüência textual, nome de autor e nome de instituição.

\footnotetext{
${ }^{24} \mathrm{O}$ mapeamento de todas as remissões de links eletrônicos pode ser encontrado em anexo.
} 
As tabelas a seguir trazem um demonstrativo da ocorrência dessas categorias funcionais do link eletrônico no ano de 2000, com artigos e reportagens que tratam do tema da Energia Nuclear. Os exemplos estão divididos conforme a tipologia hipertextual de remissão dos enunciados.

Portanto, começaremos pelo primeiro tipo de remissão hipertextual, a saber, o envio do fragmento do enunciado A, que é o próprio link eletrônico, ao enunciado B, que pertence ao próprio Dossiê temático de A, Energia Nuclear: custos de uma alternativa.

Tabela 1

\begin{tabular}{|c|c|c|c|}
\hline \multicolumn{4}{|c|}{ Remissão entre enunciados pertencentes ao mesmo dossiê } \\
\hline Gênero & Categoria & Link eletrônico / Enunciado A & Enunciado B \\
\hline Reportagem & \multirow{2}{*}{ Título } & Energia Nuclear: reacende o debate & Corpo do texto \\
\hline Artigo & & Transformações da energia & Corpo do texto \\
\hline Reportagem & \multirow{2}{*}{$\begin{array}{l}\text { Termo } \\
\text { Científico }\end{array}$} & combustíveis fósseis & $\begin{array}{l}\text { Glossário de termos } \\
\text { técnicos }\end{array}$ \\
\hline Artigo & & Não há ocorrência & \\
\hline Reportagem & \multirow{2}{*}{$\begin{array}{l}\text { Seqüência } \\
\text { Textual }\end{array}$} & $\underline{\text { energia nuclear no mundo }}$ & Texto seguinte \\
\hline Artigo & & Não há ocorrência & \\
\hline
\end{tabular}

Para a realidade do nosso corpus, o título sob forma de link interliga o sumário ao corpo do texto, tal como no caso do jornal eletrônico. Contudo, sua disposição na tela é diferenciada, uma vez que o sumário é fixo, possibilitando ao usuário verificar, a todo o momento, os textos disponíveis no dossiê temático. Em comparação com o jornal, isto é viável devido ao próprio tamanho do dossiê, que é bem menor, e, por isso, torna-se possível que o leitor visualize a totalidade de seu conteúdo fixo, ou seja, sem os links externos.

No caso da reportagem Energia Nuclear: reacende o debate, o enunciado que compõe o título, ao utilizar o termo 'debate', sugere que o autor tratará de diferentes aspectos do tema, trazendo, ou se referindo ao confronto de vozes que defendem ou repudiam a questão da energia nuclear. No corpo do texto, verificamos que o confronto ou debate ocorre entre pessoas com cargos administrativos que condenam o tamanho do investimento a ser dispensado ao 
projeto e cientistas que julgam a energia nuclear uma alternativa necessária a ser desenvolvida em favor dos recursos energéticos do Brasil.

Na reportagem Angra 2 reacende o debate sobre a energia nuclear do dossiê sobre Energia nuclear, é possível observar, a partir dos fragmentos (14) a (17) do mesmo texto, o repertório de citações utilizado e a participação de especialistas e pessoas de importante atuação na área, para constituir um panorama sobre o assunto. ...cientistas apontam a necessidade de o país investir em pesquisa e formação especializada nessa área. "Há quinze anos tínhamos mais pessoas preparadas para lidar com energia nuclear do que agora", afirma Anselmo Paschoa, ex-Diretor de Rádio-proteção da Comissão Nacional de Energia Nuclear (Cnen) e professor da PUC-Rio

(15) Os mais céticos, como Luiz Pinguelli Rosa, vice-diretor da Coordenadoria dos Projetos de Pós-graduação em Energia da UFRJ (Coppe), dizem que há alternativas a serem consideradas além da energia nuclear.

(16) Segundo a Eletronuclear, o objetivo desta fonte alternativa não é o de concorrer, a curto prazo, com as hidrelétricas, e sim o de complementar e diversificar este sistema.

(17) Ao já conhecido impacto sofrido pela população e pelo ambiente nas regiões inundadas, somam-se recentes estudos que apresentam inesperados problemas ocasionados pelas hidrelétricas. A tese de doutoramento de Marco Aurélio dos Santos em Ciências e Planejamento Energético (UFRJ-Coppe) é um desses estudos. O trabalho, Inventário de Emissões de Gases de Efeito Estufa Derivadas de Hidrelétricas, foi defendido em março deste ano e demonstra a liberação de dióxido de carbono e metano (gases causadores de efeito 
estufa) pela biomassa depositada no fundo dos reservatórios da hidrelétrica. $^{25}$

Instaura-se um debate que aponta para dois lados da questão que não são necessariamente opostos, mas complementares: a energia nuclear carente de tecnologia que a sustente no país e, ao mesmo tempo, a necessidade de utilizar uma nova fonte de energia, alternativa às hidrelétricas. É possível, a partir desses exemplos, observar que o gênero reportagem prima por incorporar e colocar em diálogo diferentes vozes-pontos de vista sobre um tema.

O próprio título do dossiê nos remete a esta discussão quando traz, em seu enunciado, a expressão ‘custos de uma alternativa’. Neste fragmento, o debate entre alto custo versus alternativa necessária já está implícito e será desenvolvido ao longo dos textos do dossiê.

Já no artigo Transformações da energia remetem à origem do universo, cujo autor é um jornalista especializado em divulgação científica (Ulisses Capazolli), o contexto de debate a que este artigo pertence neste dossiê revela uma posição positiva em torno da energia nuclear. O autor a coloca como alternativa, mais do que custos para a população, ao exemplificar e ao aproximar o uso da energia nuclear ao cotidiano das pessoas. Enquanto a reportagem explora as diferentes visões acerca do assunto, o artigo sutilmente impõe seu posicionamento, sendo o título, um fator muito convidativo para leitura. Outro fator que coopera para esta construção temática a respeito do referido assunto polêmico, sobretudo depois de fatos históricos marcantes como o ataque de bombas atômicas a Hiroshima e Nagazaki, bem como acidentes como o ocorrido em Chernobyl, é a utilização do link eletrônico para remeter a termos da esfera científica.

Para exemplificar a ocorrência desse tipo de remissão hipertextual, selecionamos o termo empregado combustíveis fósseis (ver tabela 1). Neste exemplo, é possível verificar a relação hipertextual entre o enunciado A, em que o link eletrônico combustíveis fósseis é um fragmento ou parte de enunciado, e o enunciado $\mathrm{B}$, em que o termo está disposto sob forma de verbete de um glossário explicativo de termos científicos.

\footnotetext{
${ }^{25}$ Fragmentos extraídos da reportagem Angra 2 reacende o debate sobre a energia nuclear, do dossiê sobre Energia nuclear (2000).
} 
Enunciado A

A preocupação mundial em buscar fontes alternativas às convencionais (carvão, petróleo e hidrelétricas) baseia-se no caráter não renovável dos combustíveis fósseis, na tentativa de diminuição da emissão de gás carbônico $\left(\mathrm{CO}_{2}\right)$ no aumento da demanda por energia e na escassez, em alguns países, de recursos fósseis e hídricos.

Enunciado B

2. Combustíveis fósseis - Carvão, petróleo e gás natural. Material de caráter não-renovável (finito) que se extrai da terra. Para gerar energia ele tem de ser queimado. O petróleo e o gás são formados a partir da decomposição e soterramento de animais e plantas marinhas. O carvão vem da acumulação de plantas terrestres, parcialmente decompostas, que crescem em ambientes de pântanos.

Vê-se que a relação entre os dois textos é de complementaridade, ou seja, o enunciado B é uma explicação do argumento do enunciado A, que afirma o caráter não renovável desse tipo de combustível. No entanto, o objetivo do enunciado B, por se tratar de item de um glossário, é o de aproximar ainda mais a esfera científica daquela com que o leitor está mais familiarizado, exemplificando os tipos existentes de combustíveis fósseis e explicando o processo de geração de energia por meio deles.

Em um discurso de divulgação científica é desejável que a linguagem utilizada aproxime e encoraje o leitor a percorrer a esfera científica. O termo técnico é explicado de forma que o leitor possa entender o que se passa. A reportagem possui como intenção 'reascender o debate' sobre a questão, trazendo, para isso, termos científicos em links eletrônicos. Não se observou, porém, nenhuma ocorrência dos mesmos nos artigos.

Percebe-se que o link eletrônico ocorre de maneira diferente nos artigos e reportagens. A reportagem dá ao leitor a possibilidade de entender o termo técnico por meio de um glossário ao qual o enunciado A está interligado. Já o artigo traz, no próprio corpo do texto, as explicações necessárias, bem como metáforas e maior exemplificação, pois há um ponto de vista único que visa ter aceitação mais imediata por parte do leitor.

Como já apontado anteriormente, o conjunto dos textos pertencentes ao gênero reportagem pressupõe um único texto dividido por subtítulos. Logo, ao final de cada texto, há um link eletrônico que, ao ser clicado, introduz o leitor à próxima 
reportagem. Ou seja, o link funciona como forma de seqüenciação para introduzir os fragmentos.

O segundo tipo de remissão hipertextual está explicitado na tabela 2:

Tabela 2

Remissão de enunciados do dossiê a textos de outras seções do site Com Ciência

\begin{tabular}{|l|l|l|l|}
\hline Gênero & Categoria & Link eletrônico / Enunciado A & Enunciado B \\
\hline \multirow{2}{*}{ Reportagem } & $\begin{array}{l}\text { Referência a } \\
\text { autor }\end{array}$ & $\underline{\text { Anselmo Paschoa }}$ & $\begin{array}{l}\text { Entrevista com o } \\
\text { pesquisador }\end{array}$ \\
\cline { 3 - 4 } & & \multicolumn{1}{|c}{ Não há ocorrência } & \\
\hline
\end{tabular}

Mesmo remetendo a um texto, que não do dossiê, o conteúdo temático tanto da reportagem quanto o do artigo são mantidos. A reportagem busca referência a um autor em uma das entrevistas realizadas pelo site, para compor o debate das diferentes vozes. Este autor, mais um representante da esfera científica, endossará a visão positiva acerca da energia nuclear dizendo na entrevista que "Resíduos radioativos provenientes de usinas nucleares não são os únicos existentes, nem necessariamente os que oferecem maior perigo". Vejamos os fragmentos referentes ao enunciado A e B neste exemplo (ver tabela 2):

Enunciado A

Desde a inauguração oficial de Angra 2, no último mês de julho, a utilização da energia nuclear no Brasil voltou a ser tema freqüente na imprensa. Além da antiga polêmica em torno do custo de construção da usina (mais de R\$10 bilhões, sendo quase $R \$ 7$ bilhões de juros), cientistas apontam a necessidade de o país investir em pesquisa e formação especializada nessa área. "Há quinze anos tínhamos mais pessoas preparadas para lidar com energia nuclear do que agora”, afirma Anselmo Paschoa, ex-diretor de Rádio-proteção da Comissão Nacional.

No primeiro trecho do enunciado A, o link eletrônico selecionado foi o fragmento Anselmo Paschoa. Neste enunciado, o fragmento é uma referência do discurso direto citado que o antecede. Este link nos levará a uma entrevista que o cientista concedeu à revista, na mesma época de publicação do dossiê.

Abaixo, observamos o enunciado B, que é um trecho desta entrevista. Este fragmento nos traz uma pequena apresentação da atuação do cientista em relação à causa da energia nuclear, bem como a sua importância para a esfera da ciência. 
Enunciado B

Anselmo Paschoa foi um dos responsáveis pela decisão de construir um repositório definitivo para os resíduos do acidente de Goiânia. No modelo adotado, o local onde está enterrado o lixo virou também um parque, aberto à visitação pública, com um centro de memória, onde se pode conhecer a história do acidente e obter informações sobre energia nuclear e radioatividade. “Nas condições corretas de armazenamento o repositório não oferece perigo de contaminação $e$ com circulação de pessoas há mais garantias de que sempre haverá fiscalização, pois o lugar não fica abandonado e, portanto, sujeito os acidentes”, argumenta. No entanto, segundo o físico, a tarefa política foi a mais fácil. "Na época, fiz palestras em várias escolas, falei com autoridades, estive inclusive pessoalmente com o governador do Estado para conseguir convencê-los de que era viável e segura”.

Nesta entrevista à revista Com Ciência, Paschoa analisa a situação do lixo nuclear e da segurança atômica no Brasil e fala também da situação de outros países, como Estados Unidos, França, Japão e Rússia.

Além de atribuir credibilidade tanto à reportagem quanto ao fragmento do discurso citado no enunciado A, o link relacionado ao nome do cientista possibilita uma leitura aprofundada sobre a questão. Isto faz com que haja uma fundamentação ainda mais elaborada do discurso pró-energia nuclear que está sendo estabelecido ao longo dos textos deste dossiê. Ou seja, a voz deste cientista vem se somar à idéia levantada pela revista a favor da energia nuclear. Além disso, o enunciado B traz uma informação importante sobre o pesquisador: "Anselmo Paschoa foi um dos responsáveis pela decisão de construir um repositório definitivo para os resíduos do acidente de Goiânia.”. Este fato demonstra a importância do trabalho do pesquisador e, logo, a relevância de sua opinião para a reportagem.

Na tabela 3, temos o terceiro nível de hipertextualidade delimitado nesta pesquisa, em que os fragmentos do enunciado A, sob forma de link eletrônico, levam a um enunciado B que, por sua vez, está no domínio de outro site.

Tabela 3

\begin{tabular}{|c|c|c|c|}
\hline \multicolumn{4}{|c|}{ Remissão a enunciados externos ao site } \\
\hline Gênero & Categoria & Link eletrônico / Enunciado A & Enunciado B \\
\hline Reportagem & \multirow{2}{*}{$\begin{array}{l}\text { Referência a } \\
\text { autor }\end{array}$} & Não há ocorrência & \\
\hline Artigo & & B.H. Ripin & Site Scientific American \\
\hline Reportagem & Referência à & Greenpeace & Site Greenpeace \\
\hline Artigo & instituição & Não há ocorrência & \\
\hline
\end{tabular}


Neste tipo de remissão, observamos uma rara recorrência neste dossiê: uma das três ocorrências de link eletrônico em artigos. O autor disponibiliza a referência a este outro autor, em um site mais especializado, a fim de sugerir um maior aprofundamento aos que possam se interessar, uma vez que o conteúdo do site está em língua inglesa. No caso do site do Greenpeace, o leitor é levado à página inicial do site, sem uma indicação direta a algum enunciado específico.

A referência a instituições ocorre apenas nas reportagens. As instituições citadas geralmente pertencem à esfera científica ou representam algum órgão governamental ou político, como o site do Greenpeace.

\subsubsection{Clonagem: a dessacralização da vida (2002)}

Em 2002 é possível detectar mudanças na disponibilização do conteúdo do site. Com estruturação mais elaborada, o sumário passa a indicar as seções dos textos do dossiê, o que pode implicar coerções para os próprios fatores constituintes desses gêneros e para o modo de leitura. A tabela 4 mostra as ocorrências do primeiro plano de remissão hipertextual no ano de 2002:

Tabela 4

\begin{tabular}{|c|c|c|c|}
\hline \multicolumn{4}{|c|}{ Remissão entre enunciados pertencentes ao mesmo dossiê } \\
\hline Gênero & Categoria & Link eletrônico / Enunciado A & Enunciado B \\
\hline Reportagem & \multirow{2}{*}{ Título } & Clonagem ainda é técnica em desenvolvimento & Corpo do texto \\
\hline Artigo & & Humanos ao amanhecer, Ulisses Capozoli & Corpo do texto \\
\hline Reportagem & \multirow{2}{*}{$\begin{array}{l}\text { Termo } \\
\text { científico }\end{array}$} & clonagem de animais & Outro texto \\
\hline Artigo & & Não há ocorrência & \\
\hline Reportagem & \multirow{2}{*}{$\begin{array}{l}\text { Termo } \\
\text { de } \\
\text { navegação }\end{array}$} & $\begin{array}{l}\text { Veja quais são os projetos de lei sobre clonagem } \\
\text { apresentadas ao Congresso Nacional }\end{array}$ & $\begin{array}{l}\text { Janela com } \\
\text { listagem das } \\
\text { leis }\end{array}$ \\
\hline Artigo & & Não há ocorrência & \\
\hline
\end{tabular}

Nesse momento, em que a clonagem humana representa uma preocupação para a sociedade mundial e uma discussão sobre a ética científica é estabelecida, ao contrário do posicionamento mais assertivo que se tomou a respeito da energia

\footnotetext{
${ }^{26}$ Mapeamento de todas as remissões de links eletrônicos encontradas em anexo.
} 
nuclear, observa-se um tom valorativo mais cauteloso que dá espaço para discussões mais amplas e menos argumentativas. É o que se pode depreender nos títulos tanto de reportagens (Clonagem ainda é técnica em desenvolvimento) quanto de artigos (Humanos ao amanhecer).

A relação entre título e texto é encontrada de diferentes formas. Em Clonagem ainda é técnica em desenvolvimento, o título sintetiza o tema geral do texto. Percebe-se que há trechos do mesmo texto em que se encontram fragmentos similares ao do título como em:

(18) A técnica de clonagem ainda está em aperfeiçoamento. A alta taxa de mortalidade em experimentos com animais - cerca de 90\% -, diagnósticos pré-implantacionais (antes do útero) e pré-natais, ainda em definição, alarmam para o fato de ninguém saber determinar a normalidade dos embriões. ${ }^{27}$

Já em Humanos ao amanhecer, artigo que trata da relação da ficção científica com questões da ciência, o título faz referência a uma das obras citadas pelo autor. Neste caso, o título também recupera um trecho que pode ser encontrado no texto, porém não se trata de uma síntese do que fora tratado. Este título não pertence à esfera científica em si, o que se reflete no fio condutor do enunciado que faz uma contraposição de ciência e arte.

Enunciado B

Os clones podem ser o início de uma nova era, com alterações radicais no nascimento e morte, os dois extremos da vida. Mas, neste amanhecer ainda seremos humanos. Ao menos foi essa a promessa que nos fez Philip Dick.

Em Clonagem ainda é técnica em desenvolvimento, temos uma abordagem histórica dos fatos que antecederam a técnica da clonagem e que contribuíram para a atual discussão mundial sobre esta prática. Paralelamente, o artigo Humanos ao amanhecer também propõe uma cronologia da História da Clonagem, mas sob o ponto de vista artístico, verificando as ocorrências e referências da idéia da clonagem em filmes e obras literárias de ficção científica.

${ }^{27}$ Extraído da reportagem Clonagem ainda é técnica em desenvolvimento, do dossiê sobre Clonagem (2002) 
Novamente, os termos científicos (clonagem de animais, por exemplo) ocorrem com maior incidência nas reportagens. Ou seja, a estratégia de supor maior aproximação da esfera do leitor à esfera científica nos artigos ainda é mantida.

Enunciado A

A clonagem de animais no Brasil foi iniciada em março de 2001 com o nascimento de Vitória, uma bezerra da raça simental desenvolvida pela equipe de Rodolfo Rumpf, coordenador do projeto de biotecnologia de reprodução animal da Embrapa. De lá pra cá, nenhum outro animal foi clonado, embora alguns grupos venham desenvolvendo pesquisa, principalmente em clonagem de bezerros. Esses animais são escolhidos por terem apelo comercial e por terem um período de gestação longo o que gera, normalmente, apenas um indivíduo. O fato de originar, através dos métodos naturais, apenas um indivíduo por gestação dificulta a perpetuação de algumas características que são interessantes para o comércio, como por exemplo, uma maior produção de leite ou a alta taxa de músculos. A clonagem de bovinos poderia facilitar a reprodução de animais com certas características genéticas. Para os galináceos, que podem se reproduzir em um período curto de tempo e gerar inúmeros indivíduos, a clonagem não seria tão interessante.

Enunciado B

A clonagem animal passou a ser mais conhecida em 1997, quando pesquisadores do Instituto Roslin, da Escócia, anunciaram a clonagem do primeiro mamífero, a partir de células mamárias de uma ovelha. O nascimento de Dolly, como foi chamada a ovelhinha, marcou o início de uma corrida pelo aperfeiçoamento da técnica que, se em humanos cria expectativas que ainda não podem ser satisfeitas, e que esbarra em conceitos éticos e religiosos, em animais e plantas tem apresentado resultados positivos a uma velocidade surpreendente.

No enunciado A temos um panorama histórico sobre a clonagem de animais no Brasil. O link clonagem de animais remete a outro enunciado (B) que tratará da História da clonagem de animais no mundo. Há uma relação de complementaridade, em que o link interage com o outro texto com fluidez, ou seja, um é extensão do outro.

Este dossiê apresenta expressões, que chamamos de termos de navegação, que não possuem outra função que a de pontuar e localizar o leitor quanto à disponibilização de conteúdos tanto dentro quanto fora do domínio do site. Trata-se de uma especialização do Com Ciência que pode ter sido introduzida inclusive pela observação do uso dos leitores desde o ano de seu surgimento, uma vez que esse tipo de informação é viável aos responsáveis pelo site. Nos artigos, não há este tipo de sinalização como em (19), (20) e (21). 
(19) Sendo assim, no momento em que a pesquisa tiver avançado suficientemente para garantir eficácia ao processo, não mais se justificará a oposição à clonagem reprodutiva, a qual se tornará "apenas mais uma, dentre as diferentes técnicas de fertilização assistida", como diz o geneticista Bernardo Beiguelman (veja artigo nesta edição).

(20) Na corrida para chegar ao primeiro clone humano, outro que está no páreo é o biólogo Jan Tesarik, conhecido por ter feito nascer uma criança a partir de células germinativas masculinas cultivadas in vitro. Tesarik já publicou, em maio de 2000, na revista da Sociedade Européia de Reprodução Humana e Embriologia, Human Reproduction, artigo sobre uma técnica que permite fundir dois óvulos e poderá ser útil à clonagem humana (veja também a página de Tesarik na revista eletrônica Sito Web Italiano per la Filosofia - SWIF - em italiano). ${ }^{28}$

(21) Jose B. Cibelli, vice presidente de pesquisa, Robert P. Lanza, vice presidente de desenvolvimento médico e científico, e Michael D. West, presidente, todos da Advanced Cell Technology, uma companhia privada de biotecnologia sediada em Worcester, Massachusetts (EUA), anunciaram em 25 de novembro de 2001 que haviam clonado o primeiro embrião humano (veja reportagem da Scientific American), antecipando-se aos efeitos rigorosos da nova legislação. ${ }^{29}$

Na tabela seguinte (tabela 5), verificamos a remissão de enunciados do dossiê a textos de outras seções do site Com Ciência, no ano de 2002.

\footnotetext{
${ }^{28}$ Fragmentos extraídos da reportagem Quem defende a clonagem humana, do dossiê Clonagem (2002).

29 Extraído da reportagem Políticos tentam regulamentar mundialmente a clonagem, do dossiê Clonagem (2002).
} 
Tabela 5

\begin{tabular}{|l|l|l|l|}
\hline \multicolumn{4}{|c|}{ Remissão de enunciados do dossiê a textos de outras seções do site Com Ciência } \\
\hline Gênero & Categoria & Link eletrônico / Enunciado A & Enunciado B \\
\hline Reportagem & \multirow{2}{*}{ Termo de navegação } & Não há ocorrência & \\
\cline { 3 - 4 } & & resenha, notícia & Resenha do filme Gattaca \\
\hline Artigo & \multirow{2}{*}{ Reportagem } & Não há ocorrência & \\
\hline Artigo & & Gattaca & Resenha do filme Gattaca \\
\cline { 3 - 4 } & &
\end{tabular}

Este tipo de remissão é pouco utilizado, mesmo com a especialização ocorrida no site. Curiosamente, no ano 2002, ocorreu somente nos artigos, como é o caso da indicação para uma resenha crítica, uma notícia e a referência ao nome de um filme citado que também levará a uma resenha sobre ele. Trata-se de um artigo que não possui a pretensão de pontuar uma argumentação sobre o assunto do dossiê, parecendo, ele mesmo, mais uma resenha acerca do que já foi produzido em termos de produções cinematográficas.

(22) Talvez a produção mais bem cuidada do cinema a tratar do tema da engenharia genética seja o polêmico e instigante GATTACA (veja resenha), produção norte americana de 1997, dirigida por Andrew Niccol, com Uma Thurman e Ethan Hawke no elenco.

(23) Gattaca, de Andrew Niccol.

(24) Um de meus trabalhos, a HQtrônica (história em quadrinhos eletrônica) NeoMaso Prometeu [veja notícia], que recebeu menção honrosa no $13^{\circ}$ Videobrasil (...) ${ }^{30}$

Segundo esses fragmentos, tem-se a impressão de que o artigo objetiva oferecer ao leitor referências sobre a clonagem na mídia, e apresentar mais fontes, como resenha e notícia, que já haviam sido publicadas no site.

Na tabela 6, encerrando a seleção de links eletrônicos desse dossiê, observaremos o terceiro tipo de hipertextualidade instaurada, aquele, em que o

\footnotetext{
30 Fragmentos extraídos do artigo Seres Híbridos \& Clones: Da Literatura para as Telas, das Telas para a Realidade, do dossiê clonagem (2002).
} 
enunciado A é interno ao dossiê e está relacionado a um enunciado B fora dos domínios do site.

Tabela 6

\begin{tabular}{|c|c|c|c|}
\hline \multicolumn{4}{|c|}{ Remissão a enunciados externos ao site } \\
\hline Gênero & Categoria & Link eletrônico / Enunciado A & Enunciado B (Sites externos) \\
\hline Reportagem & \multirow{2}{*}{$\begin{array}{l}\text { Titulo de } \\
\text { publicação }\end{array}$} & Therapeutic cloning: how it's done & www.scientifamerican.com \\
\hline Artigo & & $\underline{\mathrm{O} \text { estudo de gêmeos }}$ & $\begin{array}{l}\text { http://www.desvirtual.com/bbei } \\
\text { guel/ebook.htm }\end{array}$ \\
\hline Reportagem & \multirow{2}{*}{$\begin{array}{l}\text { Termo de } \\
\text { navegação }\end{array}$} & $\begin{array}{l}\text { veja reportagem da Scientific } \\
\underline{\text { American }}\end{array}$ & www.scientifamerican.com \\
\hline Artigo & & Não há ocorrência & \\
\hline Reportagem & \multirow{2}{*}{$\begin{array}{l}\text { Nome de } \\
\text { autor }\end{array}$} & $\underline{\text { Panos Zavos }}$ & $\begin{array}{l}\text { http://www.aia- } \\
\text { zavos.com/drz.htm }\end{array}$ \\
\hline Artigo & & Não há ocorrência & - \\
\hline Reportagem & \multirow{2}{*}{$\begin{array}{l}\text { Nome de } \\
\text { instituição }\end{array}$} & Genetic Savings \& Clone & http://www.savingsandclone.com/ \\
\hline Artigo & & Não há ocorrência & $\longrightarrow$ \\
\hline
\end{tabular}

A recorrência de links eletrônicos que levam a um site externo é bem mais produtiva nesse dossiê temático. Uma das hipóteses é que o dossiê evita tomar um posicionamento em relação à questão da clonagem, preferindo fazer compilações históricas e de manifestação de opiniões alheias a este respeito. Ou seja, não há compromisso do site em torno do assunto

Com isso, verifica-se a citação direta a títulos de publicações (Therapeutic cloning: how it's done e $O$ estudo de gêmeos). A terminologia de navegação que auxilia o leitor na sua busca no site, chega a indicar informações em outros sites, como no exemplo veja reportagem da Scientific American. No entanto, muitas vezes, o leitor quando levado a outro site como no caso da Scientific American, não é conectado diretamente ao assunto ou tópico sugerido pelo Com Ciência, tendo, dessa forma, que procurar pelo conteúdo indicado.

No caso, tanto as referências ao nome do autor, como as do nome da instituição, possuem funcionalidade parecida ao do dossiê anterior, isto é, prover o leitor mais interessado e mesmo mais especializado com informações adicionais, a título de aprofundamento das questões que estão sendo abordadas, embora, neste caso, seja ainda mais interessante discursivamente citar e não se posicionar. 


\subsubsection{Células-Tronco (2004) ${ }^{31}$}

O dossiê do ano de 2004 representa um salto de qualidade se comparado ao ano inicial de nossa análise. O texto é mais conciso e concentra as informações de forma mais adequada. Ao mesmo tempo, outras características foram mantidas, como o sumário, em que os gêneros do discurso estão explicitados, e a qualidade de imagens e ilustrações.

A questão das células-tronco, nesse momento histórico, passa por uma situação semelhante ao que ocorreu com o tema da clonagem. Tanto a esfera científica quanto a midiática expressam, ao mesmo tempo, temor e crença na utilização desses tipos de células para tratamentos e uma nova discussão bioética é instaurada.

É o que se pode notar nos títulos tanto da reportagem (O contrafluxo da pesquisa com células-tronco) quanto o do artigo (Clonagem terapêutica... $e$ polêmica). A seguir, temos a tabela 7, que traz o primeiro nível de hipertextualidade estabelecido no interior do dossiê sobre células-tronco:

Tabela 7

\begin{tabular}{|c|c|c|c|}
\hline \multicolumn{4}{|c|}{ Remissão entre enunciados pertencentes ao mesmo dossiê } \\
\hline Gênero & Categoria & Link eletrônico / Enunciado A & Enunciado B \\
\hline Reportagem & \multirow[b]{2}{*}{ Títulos } & $\underline{\mathrm{O} \text { contra fluxo da pesquisa com células-tronco }}$ & Corpo do texto \\
\hline Artigo & & $\begin{array}{l}\text { Clonagem terapêutica... e polêmica, } \\
\underline{\text { Lygia Pereira }}\end{array}$ & Corpo do texto \\
\hline Reportagem & \multirow{2}{*}{$\begin{array}{l}\text { Nota de } \\
\text { rodapé }\end{array}$} & Não há ocorrência & \\
\hline Artigo & & Há 9 ocorrências & Final de cada texto \\
\hline Reportagem & \multirow{2}{*}{ Expressão } & reportagem & Outro texto do site \\
\hline Artigo & & Clique para ver a figura & Nova janela \\
\hline Reportagem & \multirow{2}{*}{ Assinatura } & $\underline{\mathrm{LZ}}$ & Secção créditos \\
\hline Artigo & & Não há ocorrência & - \\
\hline
\end{tabular}

Ao aprofundar-nos enunciados B que estão relacionados ao artigo e à reportagem, verificamos uma diferença em relação ao dossiê que tratou da clonagem. Antes de afirmar seu posicionamento a respeito da questão, a reportagem traz o debate sobre a ética existente em diferentes esferas da atividade humana,

\footnotetext{
${ }^{31}$ Mapeamento de todas as remissões de links eletrônicos encontradas em anexo.
} 
sobretudo a religiosa. O artigo, indo mais além, faz um minucioso histórico sobre a técnica de clonagem que levou ao aparecimento da ovelha Dolly, primeiro ser vivo animal a ser clonado, e posiciona-se a favor da utilização das células-tronco, fazendo a seguinte afirmação: Confusões conceituais à parte é uma lástima que o país ceda às pressões de grupos religiosos e proíba de forma radical a pesquisa com embriões humanos.

Em um primeiro momento, pode-se pensar que a posição do dossiê será parecida à do anterior. No entanto, verifica-se um amadurecimento da forma de tratamento do tema, que é desdobramento da questão da clonagem, tratada anteriormente. Há, também, uma novidade no que tange aos aspectos composicionais do artigo: a introdução de notas de rodapé, cujos números interligam-se às notas no final de texto.

As notas de rodapé geralmente adicionam algum tipo de informação ao texto, tal como referência bibliográfica, explicação acerca de um item exposto no texto, ou até mesmo, uma complementação do que está sendo dito. No caso dos enunciados A e B abaixo, temos um exemplo de como as notas de rodapé estabelecem uma relação dialógica hipertextual:

Enunciado A

Mais recentemente, isso foi demonstrado para leucemias humanas, por Blair e colaboradores $e$ Bonnet e Dick. Utilizando camundongos imunodeficientes (animais desprovidos de sistema imune e portanto incapazes de rejeitar quaisquer células), mostraram que apenas uma fração de células leucêmicas de leucemia mielóide aguda (LMA) era capaz de gerar doença (por exemplo, proliferar). Essa população correspondia à fração com características de células-tronco, similares às célulastronco hematopoiéticas ${ }^{2}$.

Enunciado B

2. As células tronco hematopiéticas são bem caracterizadas quanto às moléculas que expressam em sua superfície. Estas características, que chamamos de fenótipo, permitem que sejam identificadas e purificadas a partir de uma população heterogênea.

No entanto, a nota de rodapé acima funciona como um glossário, explicando o conceito do termo hematopiéticas de forma mais simplificada, facilitando a leitura do enunciado A.

As expressões utilizadas especificamente para indicar a navegação (termos de navegação) dentro do site permanecem e são acrescentadas assinaturas com as 
iniciais dos autores sob forma de link, para que o leitor possa relacionar o texto lido diretamente com as informações sobre o seu autor, na seção Créditos. Observemos os enunciados A e B, em que LZ corresponde às iniciais de Luciene Zanchetta.

Enunciado A

$(\underline{L Z})$

Enunciado B

Brasil já tem resultados em pesquisas com células-tronco, Luciene Zanchetta

A tabela 8 representa links eletrônicos que constituem o terceiro nível de hipertextualidade, uma vez que não houve registro do segundo nível neste período. Esse segundo nível não apresentava grande produtividade nos dossiês anteriores, o que não significa que não ocorrem em outros dossiês da época atual. Na verdade, este nível ocorre de acordo com as necessidades de se recorrer a outro texto referente ao mesmo assunto dos dossiês dentro dos domínios do site.

Tabela 8

\begin{tabular}{|c|c|c|c|}
\hline \multicolumn{4}{|c|}{ Remissão a enunciados externos ao site } \\
\hline Gênero & Categoria & Link eletrônico / Enunciado A & Enunciado B (Sites externos) \\
\hline Reportagem & \multirow{2}{*}{$\begin{array}{l}\text { Título de } \\
\text { publicação }\end{array}$} & $\begin{array}{l}\text { Manifesto contra a utilização de } \\
\text { embriões humanos em pesquisa }\end{array}$ & $\begin{array}{l}\text { http://www.pucsp.br/fecult } \\
\text { ura/b004embr.htm }\end{array}$ \\
\hline Artigo & & Não há ocorrência & (2) \\
\hline Reportagem & \multirow{2}{*}{$\begin{array}{l}\text { Nome da } \\
\text { instituição }\end{array}$} & Instituto Nacional de Saúde & $\begin{array}{l}\text { http://www.pucsp.br/fecult } \\
\text { ura/b004embr.htm }\end{array}$ \\
\hline Artigo & & Não há ocorrência & 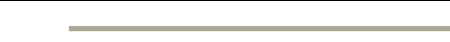 \\
\hline
\end{tabular}

A remissão hipertextual a sites externos também diminuiu bastante se comparado aos outros anos. Tirando o fato de o dossiê sobre a clonagem ter se valido de muitas informações para trazer diferentes pontos de vista do debate e, portanto, acabou utilizando links do terceiro tipo com mais freqüência, este dossiê fez um uso bastante reduzido deste tipo.

A remissão a outros sites geralmente seleciona aqueles que fazem parte das esferas científicas, jornalísticas e políticas para viabilizar maior credibilidade às 
informações prestadas. O site da Scientific American é um exemplo de site que se refere à esfera científica. Da esfera jornalística podemos citar o The business Journal e da política o próprio site da ANVISA.

Neste recorte feito na tabela 8, há referência a um título de publicação e ao nome de uma instituição. Isto reflete a própria evolução dos dossiês, que vão ficando cada vez mais especializados e com um melhor aproveitamento do mecanismo de links eletrônicos. Diríamos até que se trata de uma evolução de caráter editorial, uma vez que, ao longo do tempo, a abordagem do conteúdo temático resultou em posicionamentos mais consolidados e numa minuciosa explicação sobre os elementos da esfera científica. Os próprios gêneros apresentaram especializações quanto ao uso do link eletrônico.

O intuito desta análise foi dar conta do dialogismo entre enunciados instaurado pelos links eletrônicos. Os links eletrônicos analisados nos artigos e reportagens do corpus podem ser encontrados em três planos distintos de remissões: remissão entre enunciados pertencentes aos dossiês que compõem as reportagens especiais mensais; remissão de enunciados do dossiê a textos de outras seções do site Com Ciência e remissão a enunciados externos ao site.

Desses três planos, as remissões entre um enunciado do dossiê e um enunciado de outra seção do site são as menos produtivas. No entanto, remissões entre enunciados do mesmo site e enunciados de sites externos são freqüentes e bastante utilizados. As remissões entre enunciados do mesmo dossiê são produtivas para prover informações extras, referências, estatísticas e demais dados.

As remissões a sites externos também cumprem a função de prover o leitor com mais informações. No entanto, sendo esses sites, muitas vezes pertencentes à esfera científica, trata-se de uma fonte mais especializada para o leitor mais interessado e qualificado para prosseguir sua navegação sem prejuízos. Sites externos pertencentes a órgãos governamentais e não governamentais, bem como jornais e revistas conceituadas, sugerem credibilidade, assim como os sites da esfera científica, ao que vem sendo tratado.

Os links podem ser dispostos de formas diferentes: como títulos, subtítulos, termos científicos, termos de navegação do site, referência a autores e instituições, títulos de publicação, notas de rodapé e documentos importantes. Dessa forma, 
assume diferentes funções na medida em que trava diferentes diálogos entre os enunciados.

Quando o link relaciona o enunciado a um glossário, tabela ou janela com informações sobre o assunto, sua função é explicar, ou seja, prover o leitor de recursos que o levem a ter um maior entendimento sobre o que está sendo tratado. Sob forma de título, pode conduzir a duas situações: sintetizar o conteúdo do enunciado ou travar, antecipadamente, a polêmica que será instaurada a seguir. Quando o link se trata de um autor, publicação ou instituição, sua função é a dar referências tanto possibilitar maior aprofundamento sobre o assunto para o leitor quanto para atribuir credibilidade às informações veiculadas pelo site. Finalmente, no que diz respeito ao link enquanto item lexical que corresponde à navegação do site, este assume a função de organizar a estrutura e o possível percurso de leitura dos enunciados dos dossiês e mesmo do site Com Ciência.

Em termos de entonação valorativa, o uso de links eletrônicos em cada dossiê indica diferença no modo com que o site aborda cada questão. No primeiro dossiê, sobre a Energia Nuclear, há uma grande seleção de links sob forma de termos científicos, ou seja, na maioria das vezes, surge com a função de explicar. No que tange ao valor apreciativo deste assunto, tem-se que o Com Ciência mostra-se favorável à utilização deste tipo de fonte energética. O uso dos links reflete o posicionamento editorial desta edição do dossiê.

Outro fator que corrobora para esta afirmação é o fato de haver poucos links para sites externos e o seu aproveitamento para guiar a navegação do leitor dentro do dossiê. Ou seja, todos os esforços, mesmo que o percurso de leitura do usuário seja imprevisível por conta da estrutura hipertextual, contribuem para que o leitor permaneça dentro do dossiê e 'absorva’ o posicionamento positivo acerca da questão. Evitou-se indicar fontes contrárias, ou referências que contradissessem esta entonação valorativa.

No dossiê Clonagem percebe-se a tentativa de se assumir uma posição de neutralidade em relação ao assunto. Isto pode ter ocorrido por conta das pesquisas sobre clonagem serem ainda recentes e por envolverem questões éticas e políticas. Logo, o uso de links a sites externos aumenta consideravelmente, inclusive nos artigos como forma de buscar o que vem sendo tratado, ou seja, trazendo as diferentes apreciações valorativas sobre o tema. O dossiê não assume o compromisso de posicionar-se em relação à clonagem, mas procura trazer diferentes opiniões. O 
editorial, dessa vez, prefere-se ocultar sua voz, buscando fora as vozes que constituirão as diferentes posições do debate.

Finalmente, o dossiê sobre células-tronco possui acento valorativo parecido com o da Clonagem, trazendo muitas referências da esfera científica. Ao contrário do dossiê anterior, que também se apoiou em produções cinematográficas e outras produções da esfera da Arte, este procura ser mais assertivo. Mesmo porque, passada a grande discussão sobre clonagem na sociedade e nas esferas midiática, científica e jornalística, sente-se mais segurança em falar sobre o assunto. O Com Ciência assume um posicionamento parcial, mostrando-se favorável ao uso terapêutico das células-tronco. 


\section{Considerações finais}

A proposta de estudar gêneros da divulgação científica na internet tornou necessária a articulação de três domínios teóricos: a teoria do círculo de Bakhtin, os estudos sobre a internet e o hipertexto e abordagens da divulgação científica. Portanto, para o início da análise do corpus, fez-se uma reflexão sobre as propostas dos autores de cada área.

Como fundamentação teórica para a linguagem, trabalhou-se com as noções do círculo bakhtiniano, a saber, interação verbal, enunciado, dialogismo, esferas da atividade humana e gêneros discursivos. Considerando a língua uma atividade social e histórica, observou-se que o enunciado é mais que parte somente da materialidade lingüística, constituindo-se também como a unidade da comunicação verbal. É no enunciado que a natureza dialógica da língua se concentra, pois possui caráter ativamente responsivo, ou seja, os enunciados dialogam entre si.

Com base na noção de enunciado, as categorias conceituais aplicadas diretamente ao corpus nos capítulos analíticos foram o hipertexto presente nos links e os gêneros discursivos. A partir do entendimento sobre as relações dialógicas, foi possível analisar as relações estabelecidas pelos links eletrônicos. Em seguida, buscando a definição de gêneros do discurso e seus elementos constituintes - estilo, forma composicional e conteúdo temático - estudou-se o comportamento dos gêneros artigo e reportagem de divulgação científica na internet.

A internet e o hipertexto digital foram alvo de reflexões, uma vez que vários autores atribuem definições e terminologias diferentes a ambos. A internet foi concebida a partir da articulação da teoria de Levy (1999) com a noção de esfera do Círculo de Bakhtin. Com isso, tomou-se a internet como um espaço de comunicação que comporta diferentes esferas de atividade humana, a partir das quais se desenvolvem os mais variados gêneros discursivos.

No que tange ao hipertexto, observou-se que esta estrutura também ocorre em documentos impressos. A fim de caracterizar a sua ocorrência nos textos veiculados na internet, foi-lhe atribuída a denominação hipertexto digital. Por fim, considerou-se o hipertexto uma modalidade das relações dialógicas explícitas no enunciado, articulado pelo link, diferenciando-se da estrutura intertextual. Mais precisamente, o dialogismo estabelecido pelos links eletrônicos no hipertexto digital constitui 
relações dialógicas hipertextuais. Diferentemente da intertextualidade que se caracteriza pela inserção no corpo do texto de fragmentos de outros enunciados, as relações dialógicas hipertextuais, assinaladas pelo nó eletrônico, apontam para fora do texto.

A respeito da divulgação científica, procurou-se entendê-la junto ao acontecimento do jornalismo científico e no âmbito do que vem sendo chamado de cultura científica. A DC contrapõe-se ao JC, sendo que o último é uma das formas de divulgação existentes, e insere-se no âmbito da cultura científica, complexo processo pelo qual passa a produção da ciência. Em relação à linguagem, a DC é considerada aqui como prática discursiva que transita entre as esferas jornalística, científica e escolar.

Os links eletrônicos recortados no corpus foram selecionados e divididos em três níveis distintos de remissão. Considerando a hipótese de que os diferentes planos de remissão seriam relevantes para o estudo dos dados, a análise da pesquisa configurou-se em dois momentos. O primeiro buscou verificar a ocorrência dos diferentes tipos de remissão em cada dossiê.

As três instâncias de remissão encontradas no corpus possibilitaram o seguinte levantamento: (i) remissão dialógica hipertextual por meio de links eletrônicos entre enunciados do mesmo dossiê; (ii) remissão dialógica hipertextual entre enunciados do mesmo site (sendo o enunciado $A$ interno ao dossiê, ligando-se ao enunciado B externo ao dossiê, mas interno ao site Com Ciência); (iii) remissão dialógica hipertextual entre enunciados do dossiê a enunciados de sites externos (em que o enunciado A interno ao dossiê e, conseqüentemente ao site, liga-se a enunciados de outros sites que não o Com Ciência).

Verificou-se que as relações semânticas estabelecidas pelas remissões hipertextuais são orientadas pelos gêneros em que se inserem, bem como cumpre as funções propostas pela DC, aproximar o público de não especialistas em assuntos específicos da esfera científica.

Os links possuem diferentes funções de acordo com a orientação editorial e o tratamento dado a cada assunto. Pôde-se observar que o aproveitamento dos links na série sobre Energia Nuclear é maior para remissão de enunciados internos ao dossiê ou ao site e menor para enunciados de sites externos. Pode-se atribuir a isto o fato de que o Com Ciência tenha assumido um posicionamento favorável à questão da energia nuclear que é um assunto que suscita vivos debates. Portanto, para que o 
leitor seja convidado a refletir sobre a energia nuclear e seus benefícios, a orientação editorial sugere, por meio da distribuição dos links que estabelecem remissões internas ao site, que o leitor sirva-se das informações dispostas no dossiê.

Os nós eletrônicos que remetem a sites externos ao Com Ciência são, normalmente, utilizados para apresentar posições valorativas em contraposição à linha editorial de Com Ciência. Nesse sentido, o dossiê sobre o tema da clonagem traz um panorama geral sobre a questão, uma vez que se trata de uma questão não consensual, principalmente na esfera científica. Portanto, a opção por links que remetiam a enunciados externos ao Com Ciência cumpriu a função de informar os leitores com dados provenientes de diversas esferas (científica, religiosa e política) sem que a credibilidade do site fosse ameaçada. Tanto no dossiê sobre a clonagem quanto no dossiê sobre células-tronco, a polifonia é maior, pois há remissão a diferentes posições de diferentes esferas.

Por meio da análise, constatamos que as remissões hipertextuais internas ao site configuraram relações dialógicas de concordância, com tendência à monofonia. Nas ocorrências internas ao site, o link eletrônico ocupa diferentes funções, como a de explicar, exemplificar, demonstrar dados estatísticos e fatos históricos ou, ainda, complementar a informação veiculada. Já as remissões hipertextuais externas ao site caracterizaram posições em confronto, possibilitando o estabelecimento da polifonia. Neste caso, geralmente há abertura para a presença de outra voz, com apreciação de valor contrária. $^{32}$

O segundo momento da análise centrou-se na questão do aproveitamento dos links eletrônicos pelos gêneros artigo e reportagem. Primeiramente ressaltou-se que os gêneros discursivos podem ser considerados gêneros digitais, ao lado de gêneros como o e-mail e o blog, pois apresentam marcas da tecnologia computacional em sua estrutura composicional. Tais recursos permitidos pelo computador modificam a própria instância de recepção de tais gêneros, fazendo com que a leitura de um artigo ou reportagem seja influenciada pela possibilidade de se enveredar por diferentes links eletrônicos, o que cria diferentes percursos discursivos de leitura.

A incidência dos links eletrônicos é maior em reportagens do que em artigos. Isto pode ocorrer, pois a reportagem possui um caráter mais informativo e sua forma composicional comporta mais links. Por outro lado, o artigo possui traços mais

\footnotetext{
${ }^{32}$ Essas reflexões são decorrentes das observações feitas pela professora Roxane Helena Rodrigues Rojo, durante a defesa da dissertação, a quem manifesto meus sinceros agradecimentos.
} 
argumentativos e autorais, pois reflete, de forma mais explícita, o posicionamento de seu autor e não tem a preocupação de ser imparcial como ocorre na reportagem. Mesmo que se preocupe em demonstrar fatos ou opiniões contrárias, os artigos servirão para reforçar a idéia proposta pelo seu autor. Neste caso, a função do link eletrônico é a de atrelar informações que colaborem para a construção de uma linha de pensamento mais uniforme.

Por meio desta reflexão, acredita-se que a utilização do link eletrônico está refletida em dois fatores constituintes desses gêneros discursivos: a forma composicional e o conteúdo temático. No primeiro caso, temos a maior incidência do link em reportagens do que em artigos, o que modifica suas próprias formas composicionais e de construção do texto. Sob o ponto de vista do conteúdo temático, a utilização dos links nos artigos visa buscar informações ou 'vozes' que, mesmo que contrárias, servirão para confirmar uma hipótese lançada pelo enunciador do texto. Enquanto isso, as reportagens selecionam maior quantidade de links cuja função é de complementaridade das informações predispostas no conteúdo do dossiê.

As duas etapas da análise contribuíram para a verificação do aproveitamento dos links eletrônicos segundo cada nível de remissão hipertextual encontrado, bem como os gêneros em que estão inseridos. De acordo com a apreciação valorativa da revista eletrônica em relação ao assunto abordado, o uso do link sofre variações. Quando há remissão a documentos internos, tende à monofonia, pois busca a sanção positiva dos indivíduos leitores. Quando a remissão aponta ao exterior, tende à polifonia. 


\section{Referências bibliográficas}

ARAÚJO, Júlio César Rosa de. A conversa na web: o estudo da transmutação em um gênero textual. In: MARCUSCHI, L.; XAVIER, A. Hipertexto e gêneros digitais. Rio de Janeiro: Lucerna, 2004.

AUTHIER-REVUZ, Jacqueline. A encenação da comunicação no discurso de divulgação científica. In: Palavras incertas: as não coincidências do dizer. Campinas: Editora da Unicamp, 1998.

BAKHTIN, Mikhail \& MEDEVDEV, P. The formal method in literary scholarship. Translated by Albert J. Wehrle. Baltimore and London, The Johns Hopkins University Press, 1991. (Original russo:1928)

BAKHTIN, Mikhail. Os gêneros do discurso. In: Estética da criação verbal. Trad. Paulo Bezerra. São Paulo: Martins Fontes, 2003. (Original russo: 1952-53)

Problemas da Poética de Dostoiéviski. Trad. Paulo Bezerra. São Paulo: Martins Fontes, 2003, p.181-272. (Original russo: 1963)

O problema do texto na lingüística, na filologia e em outras ciências humanas. In: Estética da criação verbal. Trad. Paulo Bezerra. São Paulo: Martins Fontes, 2003. (Original russo: 1977)

. A pessoa que fala no romance. In: Questões de Literatura e Estética. A teoria do romance. Trad. A. F. Bernardini et al., 3ª ed. São Paulo: Hucitec, 1993. (Original russo: 1975)

/VOLOSHINOV. Marxismo e filosofia da linguagem. Trad. do francês de Michel Lahud e Yara Frateschi Vieira, 11ª ed. São Paulo: Hucitec, 2004. (Original russo: 1929)

BARROS, Diana Luz Pessoa de \& FIORIN, José Luiz. Dialogismo, Polifonia, Intertextualidade: Em torno de Bakhtin. São Paulo: EDUSP, 2003.

BARROS, Diana Luz Pessoa de. Dialogismo, Polifonia e Enunciação. In: BARROS, Diana Luz Pessoa de \& FIORIN, José Luiz (org.). Dialogismo, Polifonia, Intertextualidade: Em torno de Bakhtin. São Paulo: EDUSP, 2003. 
BRAIT, Beth (org). Bakhtin: conceitos-chave. São Paulo: Contexto, 2005.

\& MELO, Rosineide de. Enunciado / enunciado concreto / enunciação. In: BRAIT, Beth (org). Bakhtin: conceitos-chave. São Paulo: Contexto, 2005.

(org.). Bakhtin: outros conceitos-chave. São Paulo: Contexto, 2006.

Análise e teoria do discurso. In: BRAIT, Beth (org). Bakhtin: outros conceitos-chave. São Paulo: Contexto, 2006.

BRIGGS, Asa \& BURKE, Peter. Uma história social da mídia: de Gutenberg à Internet. Rio de Janeiro: Jorge Zahar, 2004.

BUENO, Wilson da Costa. Jornalismo Científico no Brasil: os compromissos de uma prática dependente. Escola de Comunicações e Artes, Universidade de São Paulo (Tese de doutorado), 1984.

CASTELLS, Manuel. A sociedade em rede. São Paulo: Paz e Terra, 1999.

CAVALCANTE, Marianne C. B. Mapeamento e produção de sentido: os links no hipertexto. In: MARCUSCHI, L.; XAVIER, A. Hipertexto e gêneros digitais. Rio de Janeiro: Lucerna, 2004.

CEREJA, William. Significação e tema. In: BRAIT, Beth (org). Bakhtin: conceitoschave. São Paulo: Contexto, 2005.

COM CIÊNCIA revista eletrônica. Desenvolvida pelo Labjor da UNICAMP. Disponível em $<$ www.comciencia.br $>$.

DEITEL, H. M. Java, como programar. 4. ed. - Porto Alegre: Bookman, 2003.

DIAS, Cláudia Augusto. Hipertexto: evolução histórica e efeitos sociais. Ci. Inf., set./dez. 1999, vol.28, n.3, p.269-277.

FERRARI, Pollyana. Jornalismo digital. 2. ed. - São Paulo: Contexto, 2004. (Coleção Comunicação). 
FIORIN, José Luiz. Polifonia textual e discursiva. In: BARROS, Diana Luz Pessoa de \& FIORIN, José Luiz. Dialogismo, Polifonia, Intertextualidade: Em torno de Bakhtin. São Paulo: EDUSP, 2003.

Interdiscursividade e intertextualidade. In: BRAIT, Beth. Bakhtin: outros conceitos-chave. São Paulo: Contexto, 2006.

GALLI, Fernanda Correa Silveira. Linguagem da Internet: um meio de comunicação global. In: MARCUSCHI, L.; XAVIER, A. Hipertexto e gêneros digitais. Rio de Janeiro: Lucerna, 2004.

GRILLO, Sheila Vieira de Camargo. A produção do real em gêneros do jornal impresso. São Paulo: Humanitas, p. 25-34, 2003.

Esfera e campo. In: BRAIT, Beth. Bakhtin: outros conceitos-chave. São Paulo: Contexto, 2006.

A noção de ‘tema do gênero’ na obra do Círculo de Bakhtin. Revista Estudos Lingüísticos. Campinas, SP: 2006.

\& OLÍMPIO, Ariadne Mattos. Gêneros do discurso e ensino. Revista Filologia e Lingüística portuguesa. São Paulo: Humanitas, 2006. [No prelo]

GUIMARÃES, Eduardo (org.). Produção e circulação do conhecimento: Estado, mídia e sociedade. Campinas, SP: Pontes, 2001.

GUIMARÃES, Eduardo (org.). Produção e circulação do conhecimento: Política, Ciência e Divulgação. Campinas, SP: Pontes, 2003.

INSTITUTO TAMIS. Popularização da Internet: introdução ao uso de correio eletrônico e web. Rio de Janeiro, 1997. Disponível em < www.rnp.br $>$. Acesso em 15 de maio de 2005.

JORNALISMO CIENTÍFICO. Disponível em < www.jornalismocientífico.com.br>

LEITE, Marcelo. Promessas e problemas. Pesquisa FAPESP, São Paulo, SP, n. 100, p. 60, jun. 2004. 
LÉVY, Pierre. Cibercultura. São Paulo: Ed. 34, 1999.

MACEDO-ROUET, Mônica. Divulgação científica na Internet: mais e melhores fontes? Disponível em www.comciencia.br. Acessado em: 24 de fevereiro de 2007.

Mônica. Novos meios, velhas práticas: conseqüências da Internet para a divulgação científica. In: GUIMARÃES, Eduardo. Produção e circulação do conhecimento. Vol. II - Campinas, SP: Pontes, 2003.

MACHADO, Irene. Gêneros discursivos. In: BRAIT, Beth (org.). Bakhtin: conceitos-chave. São Paulo: Contexto, 2005.

MARCUSCHI, Luiz Antônio. O hipertexto como um novo espaço de escrita em sala de aula. In: AZEREDO, J. C. de (org.). Língua portuguesa em debate: conhecimento e ensino. Petrópolis: Vozes, 2000.

Luiz Antônio. Gêneros textuais emergentes no contexto da tecnologia digital. In: MARCUSCHI, L.; XAVIER, A. Hipertexto e gêneros digitais. Rio de Janeiro: Lucerna, p. 13-67, 2004.

Luiz Antônio. A coerência no hipertexto. In: COSCARELLI, Carla; RIBEIRO, Ana Elisa. Letramento digital: aspectos sociais e possibilidades pedagógicas. Belo Horizonte: CEALE; Autêntica, 2005.

MELO, Cristina Teixeira Vieira de. A análise do discurso em contraponto à noção de acessibilidade ilimitada da Internet. In: MARCUSCHI, L.; XAVIER, A. Hipertexto e gêneros digitais. Rio de Janeiro: Lucerna, 2004.

MOIRAND, Sophie. Formas discursivas da difusão de saberes na mídia. Rua Revista do Núcleo de Desenvolvimento da Criatividade, Campinas, SP, n.6, p. 9-24, 2000.

MONTEIRO, Mário. A. Introdução à organização de computadores. 3. ed. Rio de Janeiro: LTC, 1996.

MORETZSOHN, Sylvia. Jornalismo em tempo real: O fetiche da velocidade. Rio de Janeiro: Revan, 2002. 
OLIVEIRA, Fabíola de. Jornalismo Científico. São Paulo: Contexto, 2002. (Coleção comunicação).

ORLANDI, Eni P. Divulgação científica e efeito leitor: uma política social urbana. In: Guimarães, E. (org.). Produção e circulação do conhecimento: estado, mídia, sociedade. Campinas; Pontes, 2001.

PEREIRA, João Thomaz. Educação e sociedade da informação. In: COSCARELLI, Carla; RIBEIRO, Ana Elisa. Letramento digital: aspectos sociais e possibilidades pedagógicas. Belo Horizonte: CEALE; Autêntica, 2005.

PINHO, J.B. Jornalismo na Internet: planejamento e produção da informação online. São Paulo: Summus, 2003.

POSSENTI, Sírio. Notas um pouco céticas sobre hipertexto e construção de sentido. In: Os limites do discurso. Curitiba: Criar, 2002.

POSSENTI, Sírio. Sobre a linguagem científica e a linguagem comum. In: Os limites do discurso. Curitiba: Criar, 2002.

SILVA, T. D. Jornalismo e divulgação científica. Rua - Revista do Núcleo de Desenvolvimento da Criatividade, Campinas, SP, n.8, p.129-146, 2002.

SOBRAL, Adail. Filosofias (e filosofia) em Bakhtin. In: BRAIT, Beth (org). Bakhtin: conceitos-chave. São Paulo: Contexto, 2005.

TUFANNI, Maurício. O fogo cruzado do jornalismo de ciência. Disponível em www.comciencia.br. Acessado em: 24 de fevereiro de 2007.

VOGT, Carlos. Revista Com Ciência: Publicação eletrônica de divulgação científica. In: GUIMARÃES, Eduardo. Produção e circulação do conhecimento. Campinas: Pontes, 2001.

VOGT, Carlos. A Espiral da cultura científica. Disponível em www.comciencia.br. Acessado em: 24 de fevereiro de 2007.

VOGT, Carlos. Jornalismo Científico: O curso de pós-graduação do LABJOR. In: GUIMARÃES, Eduardo. Produção e circulação do conhecimento. Vol. II Campinas, SP: Pontes, 2003. 
VOGT, Carlos. Ciência, divulgação e leitura. Pesquisa FAPESP, São Paulo, SP, n. 100, p. 60, jun. 2004.

VOGT, Carlos. Cultura Científica: Desafios. São Paulo: Editora da Universidade de São Paulo: FAPESP, 2006.

XAVIER, Antonio Carlos. Leitura, texto e hipertexto. In: MARCUSCHI, L.; XAVIER, A. Hipertexto e gêneros digitais. Rio de Janeiro: Lucerna, 2004.

ZAMBONI, Lílian Márcia Simões. Cientistas, jornalistas e a divulgação científica: subjetividade e heterogeneidade no discurso de divulgação científica. Campinas, SP: Autores Associados, 2001. 
Anexo 


\section{Cronologia da História da Internet e do Hipertexto Digital}

1957 - A Rússia lança o Sputnik, o primeiro satélite construído pelo homem.

1958 - Os Estados Unidos estabelecem a ARPA (Agência de Projetos de Pesquisa Avançada)

1969 - A ARPANET é criada com o intuito de prover comunicação emergencial caso os EUA sofressem algum ataque de outros países, principalmente da União Soviética.

1974 - O termo 'hipertexto é criado por Theodore Nelson.

1976 - Foram lançados os primeiros computadores portáteis.

1978 - Passa a ser comercializado o computador pessoal da Apple II.

1979 - Início da comercialização da Internet nos Estados Unidos.

1981 - A IBM lança seus computadores pessoais que ficaram conhecidos como PCs.

1989 - A RNP (Rede Nacional de Pesquisa) é criada no Brasil pelo Ministério da Ciência e Tecnologia.

1989 - Tim Berners Lee propôs a World Wide Web, a Internet gráfica que conhecemos atualmente.

1991 - A Internet começa a ser implementada no Brasil.

1992 - A Internet começou a ser instalada nas principais universidades brasileiras. Ainda não existe interface gráfica e o monitor é monocromático.

1994 - É fundada a Netscape.

1995 - A Fundação Nacional de Ciências cede a Internet para interesses comerciais.

1995 - A linguagem de programação Java é desenvolvida.

1995 - No Brasil, a Internet para cunho comercial passou a ser consolidada. 


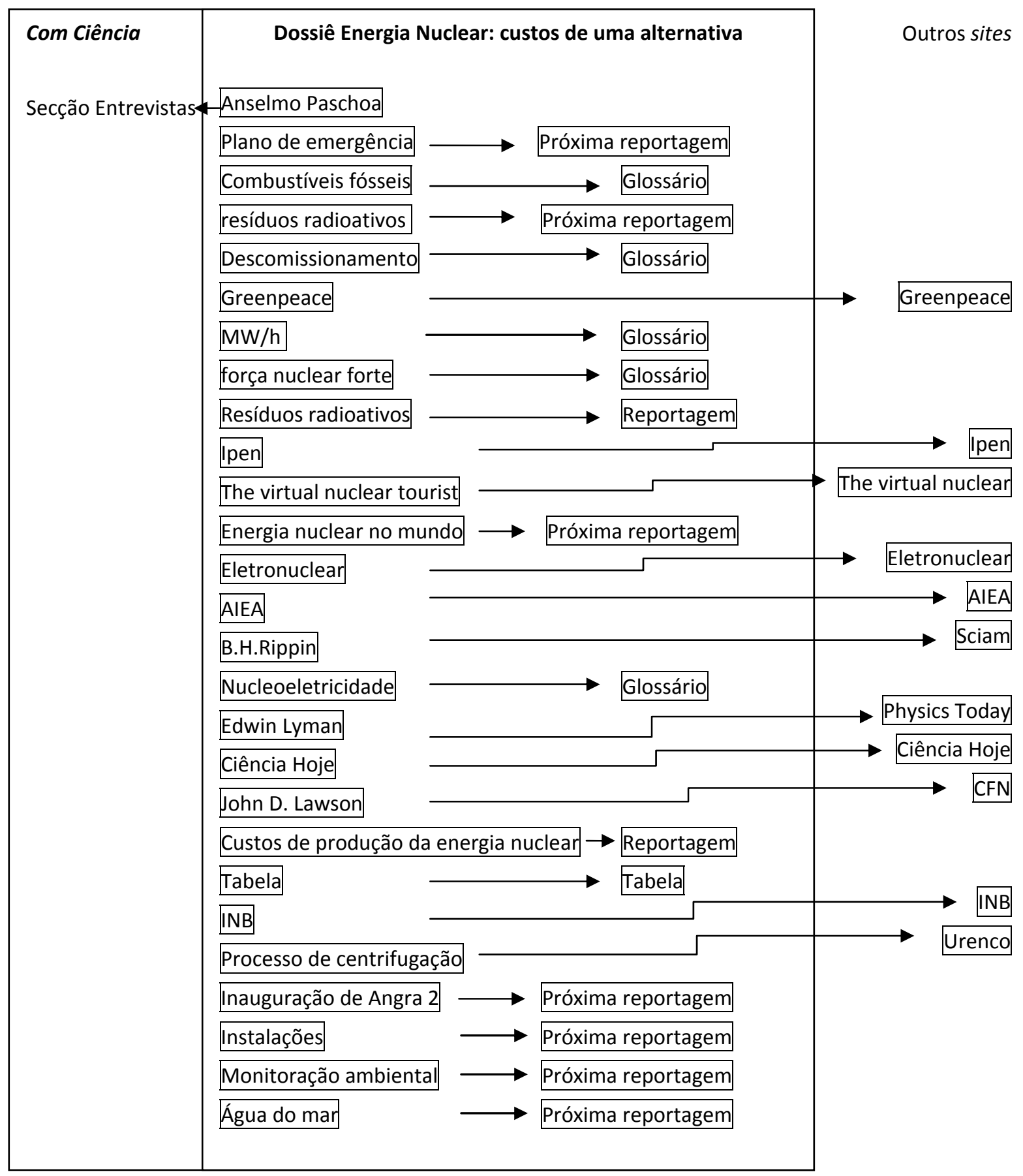


Mapeamento de remissões de links eletrônicos do dossiê Clonagem (2002)

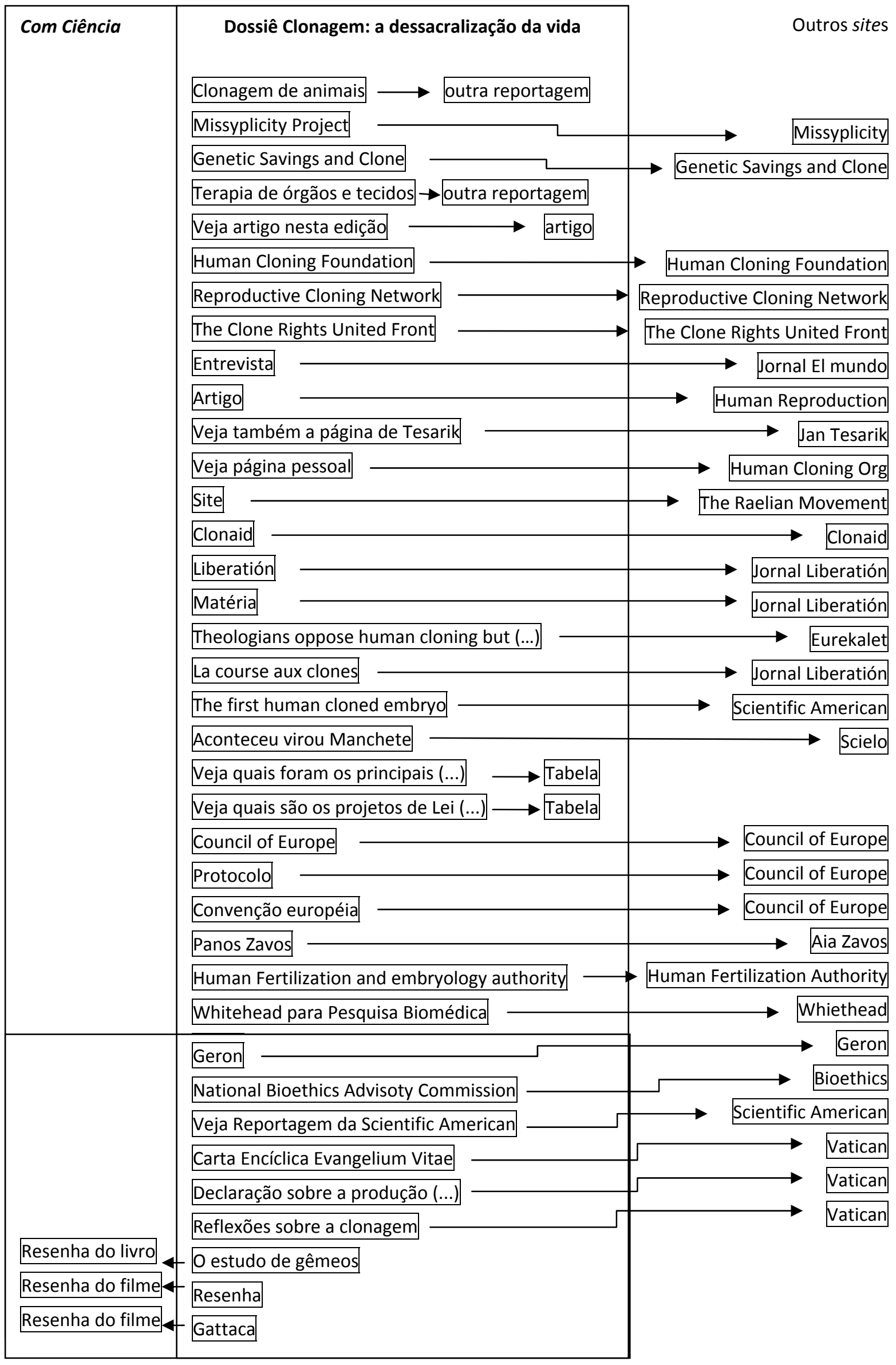


Mapeamento de remissões de links eletrônicos do dossiê Células-tronco (2004)

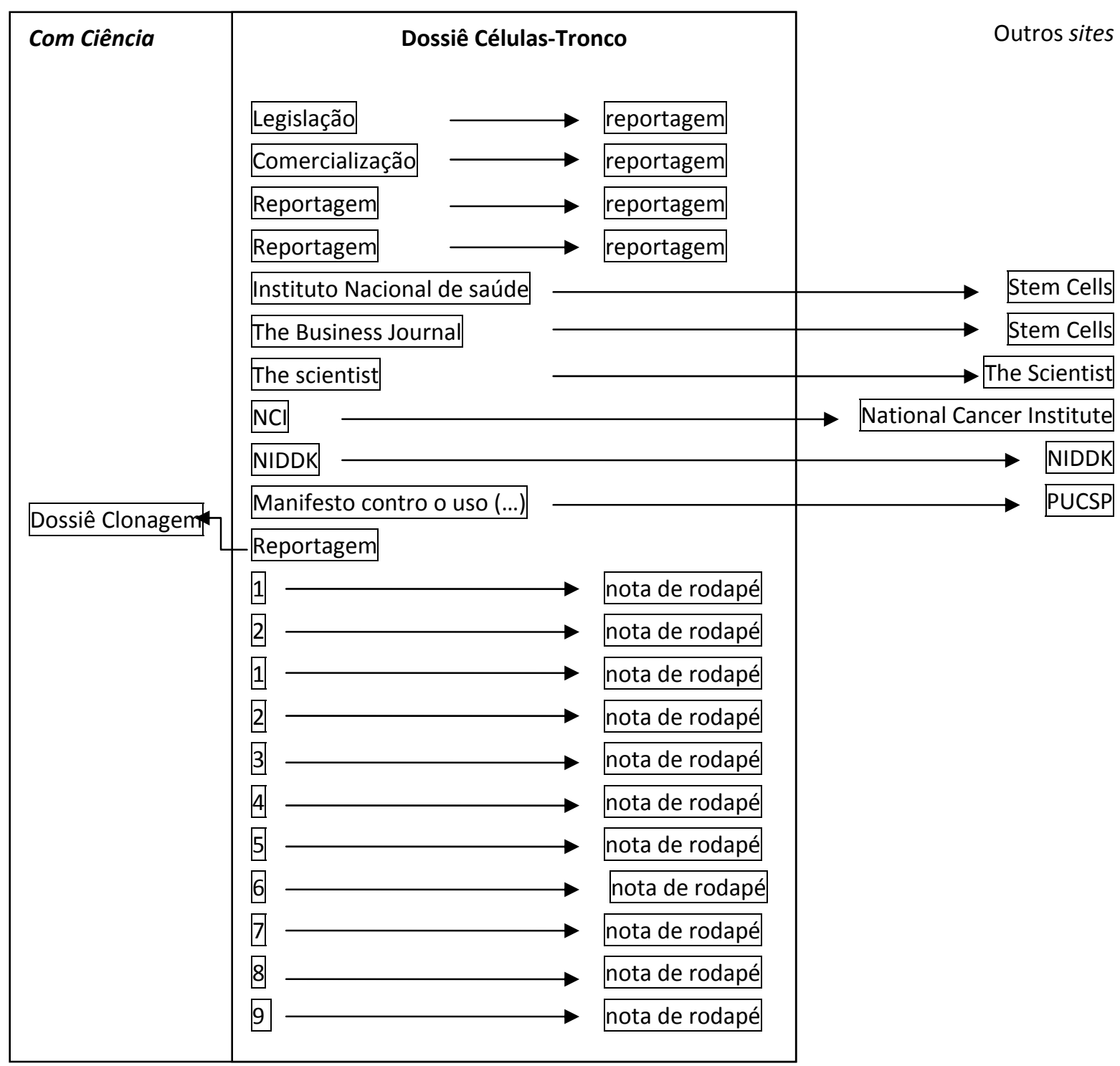




\section{ENERGIA NUCLEAR}

\section{Angra 2 reacende o debate sobre a energia nuclear}

Desde a inauguração oficial de Angra 2, no último mês de julho, a utilização da energia nuclear no Brasil voltou a ser tema freqüente na imprensa. Além da antiga polêmica em torno do custo de construção da usina (mais de $R \$ 10$ bilhões, sendo quase $R \$ 7$ bilhões de juros), cientistas apontam a necessidade de o país investir em pesquisa e formação especializada nessa área. "Há quinze anos tínhamos mais pessoas preparadas para lidar com energia nuclear do que agora", afirma Anselmo Paschoa, ex-Diretor de Rádio-proteção da Comissão Nacional de Energia Nuclear (Cnen) e professor da PUC-Rio.

Os mais céticos, como Luiz Pinguelli Rosa, vice-diretor da Coordenadoria dos Projetos de Pósgraduação em Energia da UFRJ (Coppe), dizem que há alternativas a serem consideradas além da energia nuclear. "Apenas $25 \%$ do potencial hidrelétrico do Brasil é aproveitado", argumenta, em declaração à Folha de S. Paulo (23/07/00). Pinguelli ressalta que em Angra 2, para cada quilowatt gerado, são investidos US\$6 mil, enquanto numa hidrelétrica essa relação é de US\$100/kW. O governo justifica a necessidade de construção de usinas nucleares para atender a uma demanda crescente, com projeção de déficit no suprimento de energia já em 2001.

A preocupação mundial em buscar fontes alternativas às convencionais (carvão, petróleo e hidrelétricas) baseia-se no caráter não renovável dos combustíveis fósseis, na tentativa de diminuição da emissão de gás carbônico (CO2), no aumento da demanda por energia e na escassez, em alguns países, de recursos fósseis e hídricos.

Entre as alternativas para geração de energia em larga escala, a opção nuclear é a de maior custo por causa dos investimentos em segurança dos sistemas de emergência, do armazenamento de resíduos radioativos e do descomissionamento (desmontagem definitiva e descontaminação das instalações) de usinas que atingiram suas vidas úteis. A energia gerada pela recém inaugurada Angra 2, por exemplo, terá um custo de $\mathrm{R} \$ 45,00$ por $\underline{\mathrm{MW} / \mathrm{h}}$ em contraposição aos $\mathrm{R} \$ 35,00$ por $\mathrm{MW} / \mathrm{h}$ da energia fornecida por uma hidrelétrica.

O longo e custoso processo de implantação das usinas nucleares no Brasil revela o gerenciamento inadequado desta alternativa, fato que aquece ainda mais o debate brasileiro. Angra 2, por exemplo, teve seu custo triplicado devido aos juros pagos e à sua manutenção. $O$ único ponto favorável talvez seja o fato de que a Siemens, fabricante da maior parte dos equipamentos da usina, atualizou continuamente a tecnologia a partir dos avanços técnicos realizados nesta área na Alemanha. Desde 1976, a empresa forneceu o equivalente a US\$1,27 bilhões em equipamentos e serviços.

Segundo Kleber Cosenza, superintendente de operação da Eletronuclear, a possível construção de Angra 3 teria um custo menor, em torno de RS\$2,5 bilhões, pois boa parte do equipamento foi comprado junto com o de Angra 2. Destes, já foram gastos RS\$1,3 bilhões em equipamentos comprados com os de Angra 2, na década de 80 . Eles representam $60 \%$ do que é necessário para a usina e estão estocados no Brasil e na Alemanha.

Além do custo, um dos fatores apontados é o baixo aproveitamento dos recursos hídricos no Brasil.

Segundo a Eletronuclear, o objetivo desta fonte alternativa não é o de concorrer, a curto prazo, com as hidrelétricas, e sim o de complementar e diversificar este sistema. Um dos fatos que atestam a necessidade de investimentos em fontes alternativas de energia é a baixa capacidade de expansão da produção hidrelétrica no sudeste, região de maior consumo do país. As usinas nucleares de Angra podem estabilizar o fornecimento para a região e diminuir riscos de blecautes.

No caso dos recursos hídricos, a maior parte deles concentra-se na região Norte/Amazônia (70\%) e Centro Oeste (15\%). A exploração deste potencial apresenta inúmeros inconvenientes, como o alto custo de transmissão da energia e o prejuízo ambiental que acarretará. Ao já conhecido impacto sofrido pela população e pelo ambiente nas regiões inundadas, somam-se recentes estudos que apresentam inesperados problemas ocasionados pelas hidrelétricas. A tese de doutoramento de Marco Aurélio dos Santos em Ciências e Planejamento Energético (UFRJ-Coppe) é um desses estudos. O trabalho, Inventário de Emissões de Gases de Efeito Estufa Derivadas de Hidrelétricas, foi defendido em março deste ano e demonstra a liberação de dióxido de carbono e 
metano (gases causadores de efeito estufa) pela biomassa depositada no fundo dos reservatórios da hidrelétrica.

A energia nuclear, apesar de não colaborar para a emissão desses gases, precisa lidar com o incômodo problema dos resíduos radioativos, que requerem uma solução para o armazenamento a longo prazo e investimentos em segurança, além de implicarem no fantasma de um acidente nuclear.

Optar pela energia nuclear no Brasil tem como ponto favorável o fato de possuirmos a sexta maior reserva mundial de urânio (cerca de 300 mil toneladas), suficiente para nos assegurar a independência no suprimento de combustível por muito tempo. Além disso, dois terços do território permanecem inexplorados quanto à presença do metal. No entanto, o Brasil ainda importa o urânio enriquecido (necessário para se fazer o elemento combustível), embora a tecnologia para o enriquecimento já seja aplicada no país, em escala laboratorial, para a produção de combustível de reatores de pesquisa.

Fontes renováveis de energia, como vento, energia solar e biomassa, freqüentemente são apontadas pelos ambientalistas como uma alternativa que merece maior atenção. A grande preocupação de grupos como o Greenpeace com a energia nuclear é o risco de acidentes. As fontes alternativas, no entanto, não são capazes de fornecer energia em larga escala e têm a desvantagem de serem dispersas, não fornecerem energia de forma contínua e necessitarem de uma grande área para sua implantação.

Um dado importante é o crescimento da utilização de energia nuclear no mundo, nas últimas décadas...

\section{Países europeus são os que mais utilizam energia nuclear}

Levando-se em consideração a produção total de energia elétrica no mundo, a participação da energia nuclear saltou de $0,1 \%$ para $17 \%$ em 30 anos, fazendo-a aproximar-se da porcentagem produzida pelas hidrelétricas. De acordo com a Agência Internacional de Energia Atômica (AIEA) no final de 1998 havia 434 usinas nucleares em 32 países e 36 unidades sendo construídas em 15 países.

Em termos relativos, a região que mais utiliza a nucleoeletricidade é a Europa Ocidental. Trinta por cento da energia elétrica é gerada por centrais nucleares, sendo esta a principal fonte de energia. A América do Norte fica com 17\% e Extremo Oriente e Europa Oriental com 15\%. Três países respondem por $60 \%$ do total mundial de capacidade instalada em usinas nucleares e em geração de nucleoeletricidade (Japão, França e EUA). Entre estes, destacam-se a França, com 80\% de sua energia gerada por 56 reatores nucleares, e o Japão, com 30\%.

Após alguns acidentes como o de Chernobyl (1986), diversos países diminuíram os investimentos em seus programas de produção de energia nuclear, em especial a Itália que desativou permanentemente os reatores e cancelou os projetos. Paralelamente, a indústria nuclear mundial passou a investir em segurança como forma de superar a decadência com a qual se deparou este setor na década de 80 . Um dos pontos principais foi a automação para reduzir as possibilidades de falha humana.

Ainda assim, em setembro do ano passado o acidente na usina de Tokaimura (veja Ciência Hoje, número 156) demonstrou que o risco de acidentes é um fantasma que continua rondando esta alternativa de geração de energia.

Recentemente a Alemanha decidiu que não serão instalados novos reatores e que os reatores em funcionamento serão desativados após completada a sua vida útil (32 anos neste caso). A Turquia também abandonou o projeto de construir sua primeira usina nuclear. No sentido oposto, o Brasil logo após a inauguração de Angra 2 já discute o projeto de Angra 3.

Apesar da "crise" na indústria nuclear, os países com maior necessidade desse tipo de energia, como o Japão ou a França, que não têm outras alternativas, continuarão investindo neste setor.

Os países da Organização para a Cooperação do Desenvolvimento Econômico (OCDE) são os que concentram a maior capacidade instalada de usinas nucleares no mundo e são eles que continuarão liderando o crescimento da energia nuclear a nível mundial. 
A decisão de construir usinas depende em grande parte dos custos de produção da energia nuclear...

\section{Eficiência com custo elevado}

Os custos de produção da energia elétrica são compostos de maneira diferente para cada país, pois dependem, entre outros, dos recursos naturais disponíveis em seu território. Com a crescente demanda de energia elétrica decorrente do modo de vida da sociedade moderna, mais de uma fonte de energia deveria ser estudada e aplicada, levando em conta os impactos ambientais e sociais a serem gerados a curto e longo prazos. Cada fonte apresenta vantagens e desvantagens (veja tabela). A energia nuclear é uma das mais eficientes, mas seu custo é elevado por causa dos sistemas de emergência, de contenção, de resíduo radioativo e de armazenamento.

Na composição de custos, a produção do combustível (urânio) é de grande importância.

Esquematicamente, $\mathrm{o}$ ciclo completo envolve as seguinte etapas: 1) Mineração: após a descoberta da jazida e feita sua avaliação econômica (prospeç̧ão e pesquisa), inicia-se a mineração e o beneficiamento. Na usina de beneficiamento, o urânio é extraído do minério, purificado e concentrado num sal de cor amarela, chamado "yellowcake". No Brasil, estas etapas são realizadas na Unidade de Lagoa Real (BA) das Indústrias Nucleares do Brasil (INB), de produzir 300 ton/ano de concentrado de urânio. $O$ teor e a dimensão de suas reservas são suficientes para 0 suprimento de Angra 1,2 e 3 por 100 anos. 2) Conversão do yellowcake (óxido de urânio - U3O8) em hexafluoreto de urânio (UF6) sob estado gasoso, após ter sido dissolvido e purificado. 3) Enriquecimento Isotópico: tem por objetivo aumentar a concentração de urânio 235 (U-235) acima da natural de apenas $0,7 \%$ para 2 a $5 \%$, servindo então como combustível nuclear. Esta etapa e a de conversão ainda não são realizadas no Brasil, mas na Europa por um consórcio chamado Urenco. A tecnologia de enriquecimento inclui um processo de centrifugação, onde entra o gás UF6. O isótopo U-235 de interesse é separado do isótopo U-238 mais pesado. 4) Reconversão do gás UF6 em dióxido de urânio (UO2) ao estado sólido (pó). Esta etapa é realizada em Resende (RJ), desde 1999, na Unidade II da Fábrica de Elementos Combustíveis (FEC), da INB. 5) Fabricação das Pastilhas de UO2, também na Unidade II da FEC. 6) Fabricação de Elementos Combustíveis: as pastilhas são montadas em varetas de uma liga metálica especial, o zircaloy. Esta etapa é realizada na Unidade I da FEC, também localizada em Resende (RJ).

Conforme a INB, desde 1996 o Brasil é um dos 12 países que fabricam elementos combustíveis nucleares. A partir do primeiro semestre de 1999, passou a integrar o grupo de produtores mundiais de pó e pastilhas de urânio enriquecido através da Unidade II da Fábrica de Elementos Combustíveis. Com isso, apenas duas etapas do ciclo do combustível continuarão sendo realizadas no exterior: a conversão e o enriquecimento isotópico. Esta última já é objeto de estudos realizados pelo Centro Tecnológico da Marinha em São Paulo (CTMSP), para processar no país, em escala industrial, o enriquecimento de urânio através do processo de centrifugação. Segundo José Roberto Rogero, Diretor de Materiais do Instituto de Pesquisas Energéticas e Nucleares (Ipen), em fevereiro de 2002 a INB estará enriquecendo urânio com a tecnologia comprada do CTMSP por $\mathrm{R} \$ 250$ milhões.

Outros custos também são importantes na implantação de uma usina, como os associados à construção inicial da planta e suas modificações e os sistemas de segurança, que são redundantes (todos os equipamentos têm uma duplicata pronta para ser acionada a qualquer momento em caso de acidente). Aqui são levados em conta quando e onde a usina é construída.

Há também os custos relacionados ao tratamento dos resíduos, que no caso da energia nuclear exigem um alto nível de segurança para seu armazenamento. Em Angra 1 e 2, os depósitos de lixo atômico não são definitivos. E será necessário construir depósitos permanentes, o que depende da regulamentação da lei que trata do assunto.

Após o tempo de vida útil de uma usina, deve-se também pensar nos custos de sua desativação, o que envolve isolamento da área do reator por um período de milhares de anos, construção de depósitos permanentes de lixo radioativo, entre outros. Neste ponto, é importante ressaltar que até hoje nenhuma usina nuclear foi descomissionada, ou seja, apesar de desativada, o local em que estava instalada continua isolado. 
Todas essas considerações voltam a ser objeto de debate no Brasil com a inauguração de Angra $2 \ldots$

\section{Angra 2 começa a produzir em caráter experimental}

A usina de Angra 2 entrou em funcionamento exatamente às $22 \mathrm{~h} 16$ da noite de sexta-feira, 21 de julho de 2000, em fase de testes, gerando energia complementar ao abastecimento elétrico da região sudeste. A potência do gerador atingiu então $270 \mathrm{MW}$, cerca de $20 \%$ de sua capacidade total. Para o definitivo funcionamento comercial de energia, a Usina precisa passar por um minucioso acompanhamento de todos os seus parâmetros de operação (fase final de testes), que foram adiados por solicitação da Operadora Nacional do Sistema (ONS), de modo a manter a complementação elétrica das necessidades da região.

A região de Angra dos Reis, no sul fluminense foi escolhida para a instalação do complexo nuclear brasileiro por apresentar algumas facilidades. A principal é a proximidade dos grandes centros consumidores, pois assim a usina pode fornecer energia através de linhas relativamente curtas. Angra fica (em linha reta) a 220km de São Paulo, $130 \mathrm{~km}$ do Rio e $350 \mathrm{~km}$ de Belo Horizonte, que são grandes consumidores de energia elétrica. A proximidade do mar é outro aspecto fundamental, uma vez que a usina utiliza-se de uma grande quantidade de água, em circulação, para resfriar o vapor produzido para acionar a turbina e ligar o gerador elétrico. A sua localização facilita também a chegada e saída de embarcações com equipamentos de grande porte.

$\mathrm{O}$ atual estágio de testes de Angra 2 deve se estender até setembro. Durante esse tempo, a potência será gradativamente elevada, de $30 \%$ para $80 \%$ e depois para $100 \%$. Em cada uma dessas fases, o teste consiste em verificar se a unidade responde de acordo com o que determina o projeto. Cumpridas todas as etapas, o equipamento fica oito dias operando a $100 \%$. Ao fim deste período, se tudo correr bem, a usina é declarada apta a operar comercialmente.

Angra 1, cuja produção foi interrompida em 17 de julho voltou a funcionar em 4 de agosto. Segundo o Superintendente de Produção de Angra 2, Kleber Cosenza, o Rio de Janeiro, que é um grande produtor de energia primária na forma de petróleo, ainda é dependente de outros Estados na importação de energia elétrica. As usinas de Angra somam $1.966 \mathrm{MW}$ à produção, representando aproximadamente $50 \%$ da potência total instalada no Estado. As outras fontes, a usina hidrelétrica do Funil e a de Santa Cruz, geram, respectivamente, 200MW e 600MW. A elas somam-se algumas outras pequenas usinas da Companhia de Luz do Estado do Rio de Janeiro, Light.

Angra 2, cuja tecnologia foi comprada da Siemens, alemã, impressiona pelas instalações...

\section{Usina mistura simplicidade e alta tecnologia}

Angra 2 impressiona antes de tudo pelo tamanho. Pelo tamanho das instalações e da mobilização humana que representa. Quem vem pela Rio-Santos não pode deixar de reparar na magnitude da obra, localizada em uma pequena enseada em uma das reentrâncias da serpenteante estrada. Ao entrar na área da usina e das vilas de funcionários nota-se a infra-estrutura que a Eletronuclear criou nas adjacências para tornar possível a empreitada.

As vilas de Mambucaba e Praia Grande são construídas para abrigar os funcionários, além de algumas instalações operacionais, como o Laboratório de Monitoração Ambiental e o Hotel onde funcionários, comissões técnicas e autoridades governamentais eventualmente ficam. As edificações são todas planejadas, casinhas de moradores repetem-se umas depois das outras aos olhos do passante, dando uma impressão de ordem e monotonia.

As instalações da usina são guardadas por um esquema de segurança de fazer inveja: visitantes são identificados por cartões magnéticos com um chip capaz de abrir portas somente na presença de um funcionário. Ainda assim, o visitante tem que esperá-lo entrar primeiro. E depois não pode hesitar muito: seu cartão pode abrir a porta até dois minutos depois da entrada do anfitrião. Ao fim deste tempo, o cartão expira. Todas as portas da usina têm um identificador deste tipo. A segurança é ostensiva e a vigilância deve responder por uma parcela razoável da folha de pagamentos. Os guardas das portarias e balcões de entrada comunicam-se com os visitantes somente através de microfones, pois há espessos vidros separando os dois.

Depois desta primeira impressão, o estilo de construção e o clima dentro da usina tornam-se os principais alvos da atenção. Há, nas construções, nos prédios, nos monitores de computador, nos macacões dos operários e nos painéis da sala de controle da usina uma estética dos anos 70/80, no 
estilo dos filmes de Buck Rogers ou Jornada nas Estrelas. O design dos equipamentos, que devem ser funcionais acima de tudo, desvia a atenção do visitante para essa estética. É interessante pensar que a energia nuclear e as usinas que a utilizam não representem mais tanta inovação como na época em que o Brasil começou seu projeto nuclear. Visualmente, a usina oferece uma experiência mista de alta tecnologia com simplicidade, ou até mesmo antigüidade.

A imensidão, as tubulações prateadas, os equipamentos e os ruídos e principalmente o gerador e suas turbinas tornam quase impossível não associar a experiência de uma visita à Angra 2 com os filmes de ficção científica da década de 70 e começo dos anos 80 .

Paralelamente à produção de energia elétrica, a usina mantém também atividades de pesquisa e monitoração ambiental...

\section{Laboratório controla parâmetros ambientais}

No Laboratório de Monitoração Ambiental da Eletronuclear, em Angra, o dia-a-dia consiste em medir parâmetros ambientais como radiação, teor de cloro na água do mar e temperatura. A área coberta pela equipe de quinze biólogos, químicos e técnicos abrange de Angra dos Reis até Parati. Eles se dividem nos seguinte programas: - Programa de Monitoração Operacional. - Programa de Monitoração da Fauna e Flora Marinha na fase Operacional. - Programa de Monitoração e Controle da Qualidade da Água (Salinas, Potáveis e Servidas). - Programa de Medida de Temperatura em Itaorna e Saco Piraquara de Fora (Itaorna é a praia onde está a usina. Piraquara de Fora é a enseada onde a água mais quente, proveniente do sistema de refrigeração, despejada. - Programa de Monitoração do Galpão Provisório de Rejeitos de Baixa e Média Atividades. - Programa de Medida de Cloro Residual em Piraquara de Fora.

Segundo o biólogo Carlos Alhanati, chefe do Laboratório, a Eletronuclear tem tido uma considerável preocupação em relação aos possíveis impactos ambientais de suas atividades. 0 Laboratório situa-se na Praia de Mambucaba, a 10km da Praia de Itaorna, onde fica a usina. Uma das atividades diárias de Alhanati e sua equipe é medir as variações da temperatura da água do mar causadas pela usina, que utiliza água salgada em seu sistema de resfriamento. A usina capta água em Itaorna e a despeja, depois de utilizada, no Saco Piraquara de Fora.

Dados do trabalho do Laboratório indicam que a água despejada é, em média, de 3 graus Celsius (podendo atingir 6 graus Celsius) mais quente do que a água do mar do local de descarga. Essa água, despejada a 30 metros cúbicos por segundo é capaz de aquecer a água de Piraquara de Fora cerca de um grau Celsius e meio. A usina de Angra 1 tem duas bombas de água que mantêm o fluxo contínuo. A água que passa no condensador (para resfriar o vapor expandido da turbina) recebe uma carga térmica e aquece a água do mar. Segundo Alhanati, um dos efeitos ambientais da atividade da usina é que este aquecimento é interpretado pelos peixes da região como um estímulo à reprodução. Através de um estudo em que o Laboratório coletou e analisou gônadas de peixes de várias espécies diferentes foi possível diagnosticar o fenômeno.

Diariamente são tomadas medidas de radioatividade da água do mar e dos peixes. Até hoje não se constataram níveis de radiação anormais na região. Um novo Programa de Monitoração está sendo implantado pelo Laboratório da Eletronuclear: é o Programa de Monitoração e Controle da Qualidade das Águas (Salinas, Potáveis e Servidas). Este Programa tem como objetivo principal a manutenção da boa qualidade das águas no entorno das usinas, sejam elas ligadas às questões de potabilidade, de controle das estações de esgoto ou da qualidade das águas salinas quanto aos efluentes industriais convencionais. Para isso a Eletronuclear está investindo em equipamentos e treinamentos para seus técnicos.

Há ainda outro parâmetro ambiental pelo qual o Laboratório é responsável: a medida de teor de cloro na água do mar...

\section{Cracas nas tubulações representaram desafio para engenheiros e biólogos}

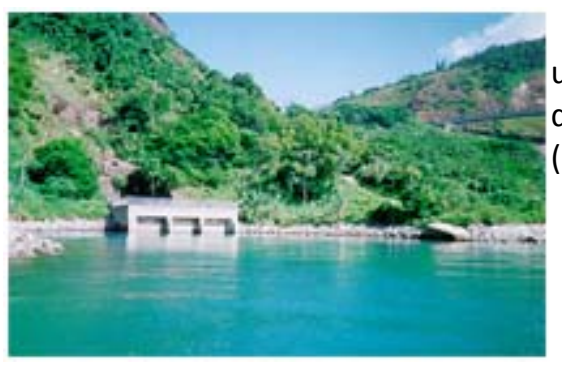

Quando a usina de Angra 1 começou a funcionar, havia uma prática corrente de tratar a água do mar com choques de cloro em concentrações relativamente altas, de 10ppm (partes por milhão). Isto porque as tubulações que despejam 
a água salgada de volta ao mar sofrem o ataque de organismos incrustantes, como as cracas, aquelas conchas aderidas às pedras. Em Angra, predominam as espécies Megabalanus tintinabulum e M. coccopoma.

Estes organismos, na fase inicial de vida, nadam livremente pela água e têm tamanho reduzido, sendo observáveis apenas com microscópios. Depois, para que possam atingir a fase adulta, eles precisam se fixar numa superfície (normalmente uma rocha). Após conseguirem se fixar, os jovens começam seu crescimento adulto, segregando uma "cola" que os faz aderirem fortemente à parede da rocha. Esta cola é uma mistura de carbonato de cálcio e um ácido que os faz aderentes o suficiente para causar danos sérios até em cascos de navios. Para evitar que isso ocorresse com as tubulações da usina é que a água do mar era tratada com doses periódicas de cloro.

A prática foi importada dos EUA, através da White Westinghouse, fabricante do reator de Angra 1. Mas o método praticado pelos americanos contra as cracas de lá não funcionava muito com as cracas daqui. Apesar de todo o cloro, elas cresciam dentro das tubulações, fazendo inclusive a usina parar para manutenção. $O$ crescimento das cracas era intenso, uma vez que no interior dos tubos elas cresciam no escuro e não havia competição por espaço com as algas, que, por precisarem de sol, são tradicionais concorrentes em ambientes naturais. Como se não bastasse, a água de dentro dos tubos era ainda mais quente que a de fora. Técnicos e engenheiros tentaram de tudo para sanar o problema, até que a solução veio pela investigação da biologia das cracas.

O trabalho de investigação, levado a cabo pelo biólogo Carlos Alhanati e pelo engenheiro Sérgio Dias, iniciou-se com mergulhos por dentro das tubulações e observação dos animais. Segundo eles, as cracas formavam placas que chegavam a $30 \mathrm{~cm}$ de espessura, crescendo umas em cima das outras. À medida em que iam ficando mais pesadas cediam e eram carregadas pelo fluxo até os tubos do condensador. Em um dos mergulhos, eles perceberam que nas curvas no túnel de admissão as cracas não cresciam. Aquele fato chamou a atenção.

Após algum tempo de estudo e levantamento de dados, conseguiu-se descobrir que as cracas não conseguem fixar-se em superfícies quando a velocidade da água é superior a 1,5 metros por segundo. E o que acontecia nas curvas dos tubos é que a água se movia mais rapidamente, impedindo a fixação das larvas de cracas. Feitos os cálculos da velocidade necessária para impedir a fixação, só faltou descobrir a peça que faltava ao quebra-cabeças: as duas bombas que mantêm o fluxo de água trabalhavam em revezamento. O fluxo produzido deslocava-se a menos de 1,5 m/s.

Então, encomendou-se aos operadores da usina que mantivessem as duas bombas operando conjuntamente, com o fluxo acima de $1,5 \mathrm{~m} / \mathrm{s}$. Depois de algum tempo as análises indicavam que a fixação de cracas tinha realmente acabado. Desde essa época a administração de cloro foi bastante reduzida, faltando apenas maiores análises para concluir qual a real contribuição do cloro no processo de impedimento do crescimento das cracas. Pesquisas estão sendo desenvolvidas em conjunto com o Instituto de Pesquisas da Marinha para o entendimento desta questão. De qualquer forma, o laboratório continua monitorando a concentração de cloro e os valores observados, em sua grande maioria, são menores que $0,01 \mathrm{ppm}$ nas águas das praias próximas à usina e a perspectiva no futuro é que seja possível parar definitivamente a administração de cloro.

Além da monitoração ambiental, uma questão que preocupa é o Plano de Emergência, em caso de acidente nuclear...

\section{Cracas nas tubulações representaram desafio para engenheiros e biólogos}

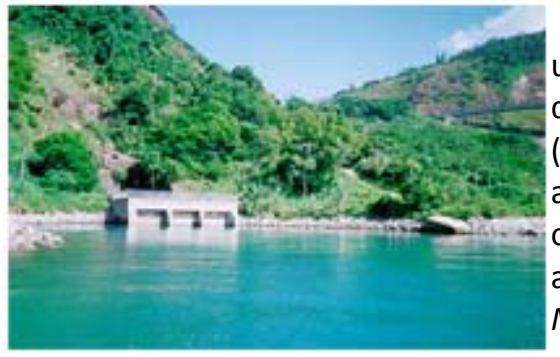

Quando a usina de Angra 1 começou a funcionar, havia uma prática corrente de tratar a água do mar com choques de cloro em concentrações relativamente altas, de 10ppm (partes por milhão). Isto porque as tubulações que despejam a água salgada de volta ao mar sofrem o ataque de organismos incrustantes, como as cracas, aquelas conchas aderidas às pedras. Em Angra, predominam as espécies Megabalanus tintinabulum e M. coccopoma.

Estes organismos, na fase inicial de vida, nadam livremente pela água e têm tamanho reduzido, sendo observáveis apenas com microscópios. Depois, para que possam atingir a fase adulta, eles precisam se fixar numa superfície (normalmente uma rocha). Após conseguirem se fixar, os jovens começam seu crescimento adulto, segregando 
uma "cola" que os faz aderirem fortemente à parede da rocha. Esta cola é uma mistura de carbonato de cálcio e um ácido que os faz aderentes o suficiente para causar danos sérios até em cascos de navios. Para evitar que isso ocorresse com as tubulações da usina é que a água do mar era tratada com doses periódicas de cloro.

A prática foi importada dos EUA, através da White Westinghouse, fabricante do reator de Angra 1. Mas o método praticado pelos americanos contra as cracas de lá não funcionava muito com as cracas daqui. Apesar de todo o cloro, elas cresciam dentro das tubulações, fazendo inclusive a usina parar para manutenção. 0 crescimento das cracas era intenso, uma vez que no interior dos tubos elas cresciam no escuro e não havia competição por espaço com as algas, que, por precisarem de sol, são tradicionais concorrentes em ambientes naturais. Como se não bastasse, a água de dentro dos tubos era ainda mais quente que a de fora. Técnicos e engenheiros tentaram de tudo para sanar o problema, até que a solução veio pela investigação da biologia das cracas.

O trabalho de investigação, levado a cabo pelo biólogo Carlos Alhanati e pelo engenheiro Sérgio Dias, iniciou-se com mergulhos por dentro das tubulações e observação dos animais. Segundo eles, as cracas formavam placas que chegavam a $30 \mathrm{~cm}$ de espessura, crescendo umas em cima das outras. À medida em que iam ficando mais pesadas cediam e eram carregadas pelo fluxo até os tubos do condensador. Em um dos mergulhos, eles perceberam que nas curvas no túnel de admissão as cracas não cresciam. Aquele fato chamou a atenção.

Após algum tempo de estudo e levantamento de dados, conseguiu-se descobrir que as cracas não conseguem fixar-se em superfícies quando a velocidade da água é superior a 1,5 metros por segundo. E o que acontecia nas curvas dos tubos é que a água se movia mais rapidamente, impedindo a fixação das larvas de cracas. Feitos os cálculos da velocidade necessária para impedir a fixação, só faltou descobrir a peça que faltava ao quebra-cabeças: as duas bombas que mantêm o fluxo de água trabalhavam em revezamento. O fluxo produzido deslocava-se a menos de 1,5 m/s.

Então, encomendou-se aos operadores da usina que mantivessem as duas bombas operando conjuntamente, com o fluxo acima de $1,5 \mathrm{~m} / \mathrm{s}$. Depois de algum tempo as análises indicavam que a fixação de cracas tinha realmente acabado. Desde essa época a administração de cloro foi bastante reduzida, faltando apenas maiores análises para concluir qual a real contribuição do cloro no processo de impedimento do crescimento das cracas. Pesquisas estão sendo desenvolvidas em conjunto com o Instituto de Pesquisas da Marinha para o entendimento desta questão. De qualquer forma, o laboratório continua monitorando a concentração de cloro e os valores observados, em sua grande maioria, são menores que 0,01ppm nas águas das praias próximas à usina e a perspectiva no futuro é que seja possível parar definitivamente a administração de cloro.

Além da monitoração ambiental, uma questão que preocupa é o Plano de Emergência, em caso de acidente nuclear...

Plano de Emergência preocupa prefeitura de Angra dos Reis

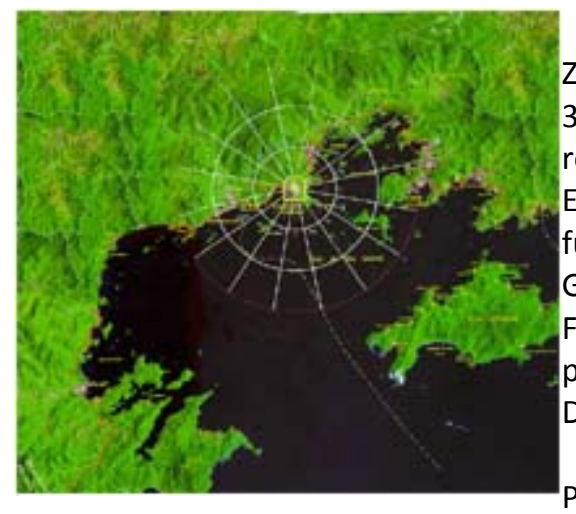

O Plano de Emergência de Angra está estruturado em Zonas de Planejamento de Emergência (ZPE), que ficam a 1, 3, 5, 10 e $15 \mathrm{~km}$ da usina. Dentro das instalações a responsabilidade pela retirada dos funcionários é da Eletronuclear. A medida mais imediata é a remoção dos funcionários para as vilas vizinhas de Mambucaba e Praia Grande. A área de responsabilidade da usina vai até $3 \mathrm{~km}$. Fora dela, a incumbência é do governo estadual com a prefeitura de Angra e os órgãos de apoio: Exército, Marinha, Defesa Civil e Corpo de Bombeiros.

Neste ponto começa uma polêmica. O afirma que o Plano de Emergência tem problemas. O mais grave são as condições da rodovia Rio-Santos. No perímetro urbano da região de Angra dos Reis, a rodovia tem quebra-molas, que reduzem a velocidade e dificultam o trânsito. Há travessia de pedestres em amplos trechos, uma vez que as vilas de Mambucaba, Praia Grande e a Vila do Frade, todas do município de Angra, cresceram muito próximas da rodovia. Habitações de baixa renda e favelas completam o quadro de precariedade da região. A rodovia Rio-Santos ainda tem pontos onde o asfalto está em péssimas condições e o

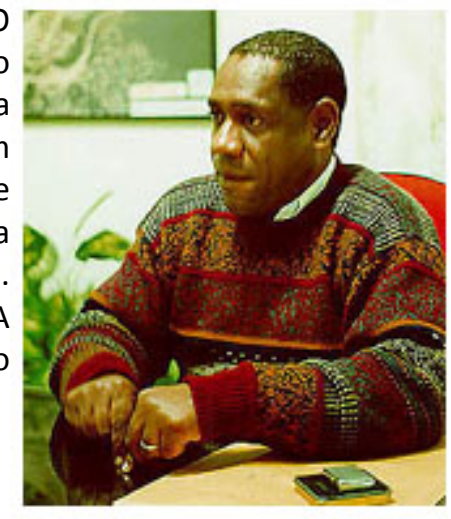


mato avança sobre a estrada. Já que a evacuação da população se daria pela Rio-Santos no caso de uma emergência, estes problemas dificultam muito a operação. A Eletronuclear tem dado apoio financeiro às obras de melhoria e recapeamento nos trechos mais críticos. Porém, a responsabilidade é do governo federal, já que se trata de uma rodovia federal.

O plano de emergência tem sido o ponto de maior conflito entre a Eletronuclear e a prefeitura de Angra. O Prefeito José Castilho reclama também da questão do impacto ambiental e social da implantação da usina: "Os benefícios das usinas Angra 1 e 2 serão sentidos em nível nacional, ou pelo menos regional, já que as usinas fornecem energia para as grandes capitais da região sudeste. Porém o impacto negativo só se refletirá em Angra dos Reis. Na época das obras de Angra 1 havia 11 mil homens trabalhando. Eles

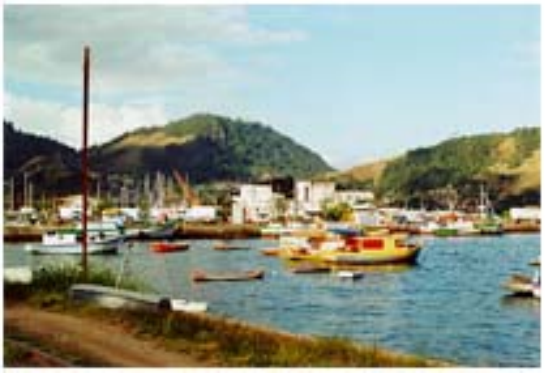
trouxeram também suas famílias e isso gerou um contingente humano imenso que a cidade teve que abrigar. Muita gente veio de outros estados. E agora para funcionar a usina não gera muitos empregos, é possível mantê-la funcionando com cerca de dois mil homens ou menos. Além disso, só recentemente ela começou a pagar impostos, já que como estatal é isenta de cobrança. A cidade arcava com custos gerados e o impacto do afluxo humano e não recebia uma contrapartida". No entanto, segundo o próprio Castilho, essa situação mudou bastante de 1988 para cá. A usina começou a pagar impostos à cidade, colabora nas obras da rodovia e o diálogo entre as partes tem melhorado. Além disso, há maior preocupação em informar e orientar a população sobre o que ocorre na usina, através da Assessoria de Comunicação da usina.

Para o Superintendente de Produção de Angra 2, Kleber Cosenza, a opinião pública brasileira, assim como o resto do mundo, tem uma tendência a associar a idéia de energia nuclear com bomba atômica. Por si só isso já cria uma resistência grande.

Além disso, há a questão dos resíduos radioativos...

\section{A confusa política nuclear brasileira}

A inauguração da usina de Angra 2 é mais um resultado da confusa, contraditória e cambiante política nuclear brasileira, que se inicia na década de 1940, resultando na criação do próprio CNPq, em 1951. Nessa política, misturam-se os mais diversos interesses de militares, políticos, grandes potências, empresários e cientistas. Na maior parte das vezes as razões energéticas foram meras justificativas para esconder estratégias militares ou interesses econômicos.

Podemos dividir o desenvolvimento nuclear brasileiro em três períodos distintos: a fase nacionalista (1949-1954), a fase diplomática (1955-74), e a fase do desenvolvimento dependente, que se inicia em 1975 e estende-se até hoje. Contudo, os primeiros trabalhos já são registrados em 1934, na Faculdade de Filosofia, Ciências e Letras da Universidade de São Paulo. Nos Anais da Academia Brasileira de Ciências em 1944 documentam-se as primeiras pesquisas sobre teorias das forças nucleares. O pesquisador Paulo Marques, em seu livro Sofismas nucleares: o jogo das trapaças na política nuclear no país, adota a divisão temporal acima para entender a história da política nuclear brasileira. Carlos Girotti, no livro Estado nuclear no Brasil, também adota uma divisão semelhante, considerando a transição, em 1975, para a fase do desenvolvimento dependente, a mais marcante.

No início da década de 40, antes da primeira bomba atômica ser detonada, os EUA, que já faziam pesquisas na área nuclear visando objetivos militares, firmam o primeiro programa para a prospecção de recursos minerais brasileiros. Este programa resultou em diversos acordos, firmados na mesma década e na seguinte, chegando o Brasil a trocar, em 1954, dez mil toneladas de minerais radioativos brutos (monazita e terras raras) por cem mil toneladas de trigo.

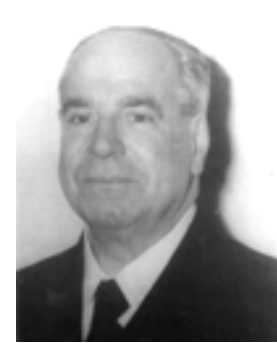

A grande figura da fase nacionalista que se inicia é o almirante Álvaro Alberto da Mota e Silva. Já em 1946, numa reunião das Nações Unidas em que os EUA propuseram um tratado internacional que criaria uma autoridade mundial responsável pela gestão de todas as reservas de urânio do mundo, o Brasil, representado pelo almirante Álvaro Alberto, juntamente com a União Soviética, são os únicos países a oporem-se ao chamado Plano Baruch, que assegurava aos EUA o monopólio da tecnologia e das matérias-primas nucleares no mundo ocidental. Nesta oportunidade, Álvaro Alberto propôs o Princípio das 
Compensações Específicas, em que o Brasil, assim como outros países subdesenvolvidos, forneceriam a matéria prima desejada em troca de um preço justo e da prioridade na instalação, em seu território, de reatores nucleares de todos os tipos.

Em 1947 é criada a Comissão de Fiscalização de Minerais Estratégicos e se inicia uma intensa disputa, dentro do Estado, de setores interessados ou não na exportação de material radioativo bruto. As exportações de monazita continuam até 1951 quando é criado, por sugestão da Comissão de Fiscalização de Materiais Estratégicos, o CNPq. Entre as atribuições do então Conselho Nacional de Pesquisas está o controle das reservas de urânio e tório que, neste momento, tem sua exportação proibida.

Entretanto, em 1952, é criada a Comissão de Exportação de Materiais Estratégicos, uma comissão que responderia diretamente ao Ministério das Relações Exteriores, sendo composta de funcionários dos ministérios da Fazenda, da Agricultura, das Forças Armadas, do CNPq e da Cacex. Ou seja, o CNPq tem o seu poder sobre as reservas de urânio e tório diluído e as exportações aos norte-americanos recomeçam. Na verdade, o Brasil estava sendo pressionado a enviar tropas para a Guerra da Coréia e, para não fazê-lo, volta a exportar o seu urânio.

Neste momento, o almirante Álvaro Alberto, que havia estudado física na Alemanha antes da Segunda Guerra, é presidente do CNPq. Usando de seus antigos contatos encomenda a físicos alemães, em 1954, a construção de três conjuntos de centrifugação para o enriquecimento de urânio. Os conjuntos acabam sendo interceptados pelo Alto Comissariado do Pós Guerra, 24 horas antes do embarque para o Brasil, a partir de denúncia feita pelo militar brasileiro Octacílio Cunha. Documentos revelados posteriormente mostram que o Brasil estaria sendo impedido de buscar o enriquecimento do urânio por ser um país localizado dentro da área de influência dos EUA.

Com o suicídio do presidente Getúlio Vargas e a exoneração de Álvaro Alberto da presidência do CNPq termina a chamada fase nacionalista. O novo presidente, Café Filho, assina, já em 1955, a integração do Brasil ao programa americano "Átomos para a Paz". O programa sinalizava que os EUA haviam desistido de impedir o acesso de outros países às tecnologias atômicas procurando agora inseri-los sob o seu controle e vigilância. Em 1956 é instaurada, sob pressão norte-americana, uma CPI para investigar supostas irregularidades no CNPq. Na verdade, o desenvolvimento atômico brasileiro é objeto de disputa entre dois setores do Estado, um representado pelo Itamaraty e outro pelo CNPq.

E é o setor representado pelo Itamaraty que vai dominar a fase diplomática. Neste mesmo ano de 1955 foram assinados dois acordos com os EUA: o Acordo de Cooperação para o Desenvolvimento de Energia Atômica com Fins Pacíficos; e o Programa Conjunto para o Reconhecimento e a Pesquisa de Urânio no Brasil. O primeiro acordo previa que o Brasil arrendaria dos EUA, por um período de cinco anos, até seis quilos de urânio enriquecido a 20\%, a ser usado como combustível para reatores de pesquisa encomendados também junto aos EUA. O segundo acordo previa a pesquisa e avaliação das reservas de urânio brasileiras, que seriam vendidas aos EUA.

Contudo, a posse de Juscelino Kubitschek em 1956, significará uma nova conjuntura para a política nuclear brasileira. São criados neste ano o IEA (Instituto de Energia Atômica) na USP - que será transformado no Ipen (Instituto de Pesquisas Energética e Nucleares) -- e a Cnen (Comissão

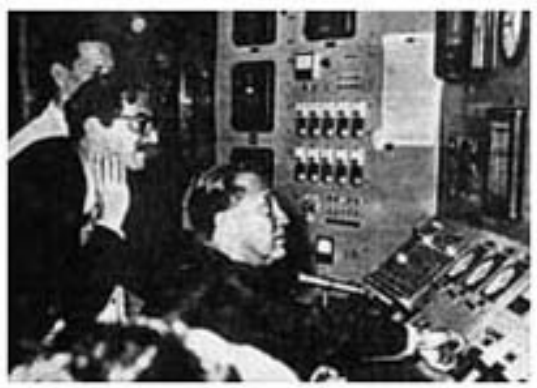
Nacional de Energia Nuclear), diretamente subordinada à presidência da república. São estabelecidas diretrizes para uma política nacional de energia nuclear, em que há uma tentativa, através de medidas aparentemente contraditórias, de resgate da autonomia no setor. Nos anos seguintes, são firmados acordos com outros países que não os EUA.

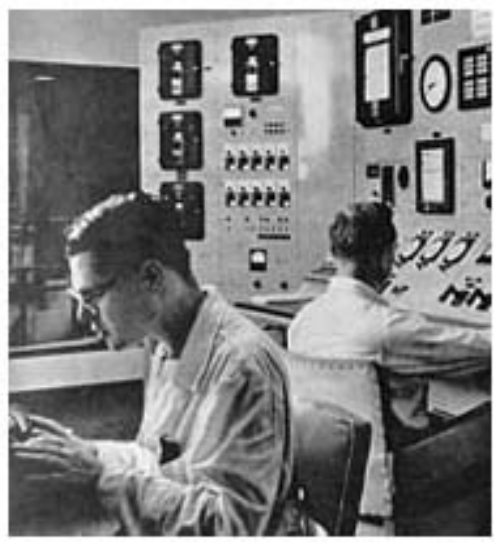

Este período é o de maior desenvolvimento dos grupos de pesquisadores nas universidades e nos centros de pesquisa. Os reatores de pesquisa norte-americanos foram trazidos a diferentes grupos de cientistas brasileiros. Criado em 1952, o Instituto de Pesquisas Radioativas (ligado à UFMG), em Belo Horizonte, é um destes grupos, mas também abriga, no final da década de 1950, o Grupo do Tório, uma equipe de pesquisadores que busca o desenvolvimento de um reator de pesquisa diferente daqueles que já operavam no Brasil, 
baseados em urânio enriquecido e água leve. O reator que buscavam desenvolver seria baseado em diferentes ciclos de combustível (não necessitando de urânio enriquecido) e água pesada. Suas pesquisas foram encerradas em 1975, quando o governo federal optou pelos reatores de água leve e firmou o Acordo com a Alemanha Ocidental.

Em 1963, o Instituto de Energia Nuclear, criado em convênio da Cnen com a UFRJ, passa a construir um reator com componentes nacionais, à exceção do combustível. Chamado de Argonauta, o reator entra em operação em 1965. Nesse momento, a Cnen é o órgão que gere a exportação de minérios para uso nuclear. Estas agências governamentais que foram criadas formaram uma burocracia técnica para o setor nuclear, com importantes consequências no desenvolvimento e manutenção do mesmo. Esta tecnocracia ganhará ainda mais importância após o golpe militar de 1964 e a conseqüente centralização do Estado.

\section{O tratamento dado aos rejeitos radioativos}

Um dos principais argumentos utilizados pelos defensores das usinas nucleares é o seu baixo nível de poluição do ambiente. Segundo eles, a usina nuclear seria capaz de produzir energia elétrica "limpa". Esta, entretanto, não costuma ser a opinião das organizações de defesa do meio ambiente, como o Greenpeace. O Greenpeace acredita que os testes já realizados envolvendo o destino do lixo nuclear são insatisfatórios e que testes confiáveis demandariam dezenas de milhares de anos.

Os rejeitos produzidos em Angra 1 e 2 podem ser classificados em três níveis de radioatividade: alta, média e baixa. Ainda não há, no Brasil, um lugar escolhido para o depósito definitivo do lixo nuclear, ficando o lixo de Angra em depósitos intermediários.

Para os rejeitos de baixa e média radioatividade (que deveriam ficar no depósito intermediário por no máximo três anos) o destino são dois galpões de concreto construídos dentro de rochas, ao lado da usina. Nestes galpões ficam armazenados tambores que, ou contém botas, macacões e outras roupas contaminadas (rejeitos de baixa radioatividade, com meia-vida aproximada de 60 anos) utilizadas por trabalhadores ou peças de metal do reator e resíduos químicos (rejeitos de média radioatividade). A maior parte dos tambores contém rejeitos de baixa radioatividade que podem, inclusive, ser reutilizados. Segundo Kleber Cosenza, Superintendente de produção de Angra 2, em uma inspeção periódica, feita há três anos, o material estocado passou de 1400 tambores para 400, devido à constatação de que aqueles objetos haviam perdido a radioatividade. Algumas peças de roupas foram reutilizadas.

O rejeito de alta radiotividade, que a indústria chama de subprodutos, é formado pelo elemento combustível já irradiado dentro do reator. Este rejeito tem uma meia-vida bastante longa, podendo chegar a dezenas de milhares de anos, o que torna a questão sobre o destino a ser dado a ele muito mais importante. Por incrível que pareça, o elemento combustível também pode ser reutilizado. Normalmente, ele é retirado do reator com apenas $15 \%$ de sua capacidade utilizada. Se a usina recebe elementos combustíveis com qualquer tipo de problema, pode recorrer ao combustível estocado a ser utilizado em combinação com o novo. O local de estocagem dos rejeitos de alta radioatividade de Angra são as suas piscinas. Para a usina de Angra 2 foi construída uma piscina dentro do reator (diferente da de Angra 1, que fica fora) com capacidade para armazenar os rejeitos produzidos por metade de sua vida útil, 20 anos. A piscina de Angra 1 pode armazenar os resíduos de seus 40 anos de atividade previstos. Ambas mantém os resíduos submersos a mais de dez metros de profundidade, sendo a água a blindagem utilizada.

O projeto que define normas para a construção de locais definitivos de armazenamento de lixo nuclear já foi aprovado pelo Congresso, estando em tramitação no Senado. Ele segue as normas internacionais, que propõe a construção de silos de concreto no subsolo. A cidade em que fossem construídos estes silos seria beneficiada com compensações financeiras. $O$ atual prefeito de Angra dos Reis, José Marcos Castilho, é contrário à escolha de sua cidade para sede também dos rejeitos.

Os ambientalistas questionam as soluções propostas pelas centrais nucleares. Segundo eles, poderia haver contaminações do ar causadas por explosões ou vazamento contínuo de gases de um sítio (possíveis teoricamente), ou contaminações da água, causadas por vazamento do invólucro que armazena o rejeito e que poderia atingir um lençol freático. $O$ fato é que, principalmente com relação aos rejeitos de alta radioatividade, a solução encontrada deve levar em conta a longa meiavida do lixo, que chega a milhares de anos 


\section{Domínio da energia nuclear vem de teorias do século XIX}

O conhecimento que tornou possível o uso da energia nuclear na geração de eletricidade, na Medicina e nas ciências dos materiais derivou de pesquisas experimentais e teóricas sobre a estrutura do átomo, concentradas principalmente no fim do século XIX e na primeira metade do século XX.

A hipótese de que a matéria é constituída de átomos foi lançada em 1803 pelo químico inglês John Dalton e evoluiu desde a condição de "teoria heterodoxa" até a aceitação por toda a comunidade científica, já nos primeiros anos do século XX. O átomo indivisível de Dalton, que lembrava vagamente o atomismo dos filósofos gregos Leucipo e Demócrito (século $V$ a.C.), sofreu grandes mudanças ao longo do século XIX e já não parecia tão maciço no início do século XX.

As origens da noção da divisibilidade do átomo podem ser remontadas à descoberta da radioatividade no urânio, pelo francês Henri Becquerel, em 1896. A polonesa Marie Curie e seu marido, o francês Pierre Curie, pesquisaram a fundo o novo fenômeno e descobriram vários elementos químicos novos muito radioativos (como o rádio, o polônio e o tório), demonstrando que a radioatividade não era privilégio do urânio. Mostraram também que as partículas que constituíam alguns tipos de radiação provinham do interior dos átomos. Enquanto isso, em 1897 o inglês John Joseph Thomson demonstrava a existência de partículas muito menores que os átomos, mais tarde chamadas elétrons. A indivisibilidade dos átomos estava em xeque.

Os detalhes da estrutura atômica foram determinados durante as décadas seguintes. A divisibilidade do átomo foi confirmada experimentalmente ao longo da década de 1910 pelos trabalhos de Ernest Rutherford e Frederick Soddy, que culminou com a descoberta do núcleo atômico em 1911, por Rutherford. Nos anos seguintes foi solidificada a convicção de que os núcleos eram compostos de partículas com carga elétrica positiva, chamadas prótons, e partículas sem carga elétrica, chamadas nêutrons. Os elétrons movem-se ao redor do núcleo. Como os elétrons são bem mais leves que os prótons e os nêutrons, o núcleo contém quase toda a massa do átomo. A existência dos nêutrons teve que esperar até 1931 para ser confirmada em laboratório, por James Chadwick.

As pesquisas penetraram cada vez mais no âmago da matéria. À compreensão da estrutura geral do átomo seguiram-se as pesquisas sobre a estrutura do núcleo. Ao longo da década de 1920 reconheceu-se que as partículas do núcleo eram mantidas juntas por uma força nova (proposta por Werner Heisenberg em 1932), mais poderosa que todas as outras conhecidas, hoje chamada de "força nuclear forte". As forças nucleares fortes são também responsáveis pela emissão de alguns tipos de radiação.

Porém, para usar a nova força para gerar energia era necessário descobrir um modo de produzir radioatividade artificialmente. Isso foi obtido em 1934, com os trabalhos dos franceses Frederick e Irene Joliot-Curie, esta filha de Pierre e Marie Curie.

O processo físico fundamental para a geração da energia nuclear, a fissão nuclear, foi descoberto por Otto Hahn, Lise Meitner e Fritz Strassman, em 1938-9. Quando o urânio é bombardeado por nêutrons, os núcleos dos átomos absorvem as partículas e tornam-se instáveis, partindo-se em dois pedaços espontaneamente. O átomo de urânio cede lugar a átomos mais leves, como bário e criptônio. A energia correspondente às forças nucleares que uniam os pedaços é subitamente liberada na forma de energia cinética (energia de movimento) dos fragmentos.

Além dos núcleos-fragmentos, a fissão produz também dois ou três nêutrons. Ao atingirem os átomos de urânio próximos, os nêutrons são absorvidos por eles e os levam à instabilidade, provocando novas fissões e novos nêutrons, que vão provocar novas fissões em novos átomos e assim por diante, numa reação nuclear em cadeia.

O próximo passo seria aprender a estabelecer uma reação em cadeia controlada, para que pudesse ser usada na geração de energia - ou seja, a invenção do reator nuclear. Entretanto, os acontecimentos políticos que se seguiram levaram as pesquisas à direção inteiramente oposta. Pouco depois da descoberta de Hahn, Meitner e Strassman, eclodiu a Segunda Guerra Mundial (1939-1945). Os estudos sobre energia nuclear desviaram-se irresistivelmente para a construção de armas nucleares. Nos Estados Unidos, o Projeto Manhattan, cujo setor científico foi liderado pelo físico Robert Oppenheimer, usou a reação nuclear em cadeia para explodir a primeira bomba atômica perto do laboratório de Los Alamos, em 1945. A segunda e a terceira caíram sobre Hiroxima e Nagasáqui, no Japão, selando a vitória norte-americana na guerra. 
O Projeto Manhattan envolveu vários dos melhores talentos da Física, como o italiano Enrico Fermi, o alemão Hans Bethe e o húngaro Leo Szilard. Após a guerra, Oppenheimer tornou-se pacifista e lutou contra o uso das armas nucleares, sendo perseguido pelo governo norteamericano. Outros físicos do Projeto Manhattan tiveram trajetória semelhante, como o australiano sir Mark Oliphant (1901-2000), falecido no último dia 17 de julho, na Austrália. Os cientistas renegados do Projeto Manhattan não foram os únicos a serem colhidos pelas malhas da política belicista dos anos 30-40. Lise Meitner e Albert Einstein, por exemplo, tiveram que fugir da Alemanha para salvar suas vidas, pelo simples fato de serem judeus.

Após a guerra, as aplicações pacíficas da energia nuclear finalmente puderam ter o seu lugar, com a construção de reatores para usinas nucleares. O primeiro reator nuclear foi construído pelo físico italiano Enrico Fermi já em 1942.

\section{Funcionamento das usinas nucleares}

O urânio usado em usinas nucleares não é o natural, sendo obtido a partir dele pelo processo de enriquecimento. Na natureza existem vários "tipos" de urânio, chamados isótopos, que diferem apenas pelo número de nêutrons existentes no núcleo. Os vários isótopos usualmente são identificados pela soma do número de prótons e de nêutrons existentes em seu núcleo. Assim, o urânio mais comum na Natureza é o urânio-238. O processo de enriquecimento consiste em adicionar urânio-235, obtendo-se uma mistura dos dois isótopos, cuja proporção depende da aplicação.

Isto é feito porque o urânio-235 (U-235) é altamente fissionável, enquanto o urânio-238 (U238) é bem mais estável, o que permite controlar a energia produzida na reação em cadeia através da proporção entre eles. Usinas nucleares usam uma proporção de 3\% de U-235 e 97\% de U-238. Reatores nucleares para pesquisa, como os do Instituto de Pesquisas Energéticas e Nucleares (Ipen), usam cerca de $20 \%$ de U-235. Já as bombas atômicas usam $90 \%$ de U-235. O urânio natural possui somente $0,7 \%$ de U-235.

O núcleo de um reator consiste de um conjunto de vários tubos longos com pastilhas de dióxido de urânio, substância que contém átomos de urânio. No urânio ocorre uma reação em cadeia causada pelas fissões do urânio-235, e a energia liberada é absorvida pelo material do reator na forma de calor - a energia nuclear contida nos núcleos atômicos é transformada em energia térmica. A temperatura da água usada para refrigerar o reator nuclear de Angra chega a $320 \stackrel{\circ}{\circ}$.

Como em qualquer usina termoelétrica (no caso, termonuclear), o calor é usado para vaporizar água. O vapor é forçado a passar pelas pás de uma turbina e a girá-la - a energia térmica é transformada em energia mecânica de rotação. O eixo da turbina comunica-se com um gerador, que transforma a energia mecânica em energia elétrica. A energia elétrica é então conduzida, através de fios e torres de transmissão, até as casas, indústrias, etc.

O processo de geração de energia elétrica a partir da energia nuclear, então, pode ser esquematizado em três passos: 1 - No reator: transformação da energia nuclear em energia térmica, através da reação nuclear em cadeia

2 - Na turbina: transformação da energia térmica em energia mecânica, através da ação do vapor d'água aquecido 3 - No gerador: transformação da energia mecânica em energia elétrica

À medida que o tempo passa, o urânio do reator vai sendo "gasto". Após 3 anos, cerca de 75\% do urânio-235 desaparece, sendo substituído pelos produtos de fissão (como o estrôncio-90 e o famoso césio-137) e por outros elementos químicos (como o plutônio, o netúnio e outros isótopos do urânio), originados quando o urânio emite radioatividade ao invés de sofrer fissão. Essas substâncias são conhecidas como "rejeitos radioativos" ou "lixo atômico", e algumas são extremamente radioativas.

Informações mais detalhadas sobre energia nuclear podem ser encontradas no site "The Virtual Nuclear Tourist" , ou no site da Eletronuclear.

Ipen desenvolve aplicações médicas da energia nuclear 
Historicamente o desenvolvimento das tecnologias nucleares sempre esteve relacionado a questões estratégicas, como por exemplo, o desenvolvimento de armamentos nucleares. Pouco se fala em tecnologia nuclear ligada aos campos da biologia e medicina. No entanto, esse vínculo vem se tornando uma opção importante na solução de problemas do ser humano e do seu meio ambiente.

O Ipen foi fundado em 1956 (com o nome de IEA, Instituto de Energia Atômica), integrando o programa norte-americano conhecido como "Átomos para a Paz". O programa fazia parte da iniciativa do governo dos Estados Unidos em permitir o desenvolvimento da tecnologia nuclear nos países periféricos voltada para aplicações não militares. O reator IEA-R1 foi o primeiro do hemisfério sul a atingir criticalidade, em setembro de 1957.

Em 1962, foi desenvolvido junto com a Primeira Clínica Médica da Faculdade de Medicina da USP um programa de pesquisas clínicas, empregando radioisótopos, principalmente no diagnóstico de doenças tireoideanas. Um composto que interage de maneira diferente com as células cancerosas é marcado com radioisótopos, que fazem com que a mistura seja identificável através de um aparelho.

Hoje o Ipen produz radioisótopos que atendem em média 1,5 milhões de pacientes por ano em diferentes exames médicos, o que gera para o instituto uma receita anual de 18 milhões de reais. Este, entretanto, é um ramo da tecnologia nuclear ainda pouco explorado no Brasil. $\mathrm{Na}$ Argentina, aproximadamente 4 milhões de pessoas utilizam-se deste tipo de tratamento anualmente e o número sobe para 20 milhões quando falamos nos EUA. Segundo José Roberto Rogero, diretor de materiais do Ipen "uma tecnologia nuclear só é usada quando ela é a melhor, a mais indicada ou quando não existe outra que possa substituí-la".

Ao Centro de Radiofarmácia do Ipen foi conferido, no final do ano passado, pela Fundação Vanzolini, a certificação ISO 9002. É o único centro do páis que produz radioisótopos com aplicações médicas.

Além da área médica, o Ipen atua junto a diversas instituições em questões de engenharia ambiental, onde os resíduos sólidos e semi-sólidos são hoje um dos maiores problemas. Em função disso, o instituto vem desenvolvendo uma metodologia de análise e tratamento de resíduos. Um dos objetos de estudo é a divisão química da Hoechst, localizada em Suzano (SP), que tem os seus resíduos analisados e a partir dessa análise determinado o seu impacto no meio ambiente. Outra aplicação de tecnologia desenvolvida no Ipen é na inspeção de vazamentos do gasoduto BrasilBolívia, feita através de Irídio.

A partir do início da década de 1980, o Ipen, através de sua Diretoria de Reatores, passou a integrar o grupo de pesquisa organizado pela Marinha do Brasil, interessado no desenvolvimento do sistema de propulsão de um submarino nuclear. O domínio do ciclo do combustível do reator, incluindo o enriquecimento do urânio, foi atingido em 1986, devido a essas pesquisas. Hoje, o Ipen é responsável pela produção de todas as etapas dos combustíveis utilizados em seus reatores de pesquisa.

\section{Transformações da energia remetem à origem do Universo}

\section{Ulisses Capozoli}

A primeira lei da termodinâmica diz que a energia não pode ser nem criada nem destruída. A termodinâmica, para quem tem menos familiaridade com a física, investiga os processos de transformação da energia e o comportamento dos sistemas envolvidos nessas ocorrências. Uma usina nuclear não existiria sem os conhecimentos dessa área.

À primeira vista, pode parecer árido e difícil envolver-se com discussões desse tipo. Mas reflexões sobre a transformação da energia podem trazer a experiência de uma profunda revisão no que parece ser a banalidade do cotidiano.

O movimento dos olhos do leitor para acompanhar esse texto, por exemplo, exige o dispêndio de uma quantidade de energia pelo organismo. Essa energia é retirada de alimentos, de origem animal ou vegetal. A fonte que supre animais e vegetais, no entanto, é o Sol e a usina de força do Sol é a fusão nuclear.

Tanto o caldeirão solar como o de outras estrelas, no entanto, só se aquecem, a milhões de graus, por efeito da gravidade.

A pressão gravitacional comprime as massas de gases que formam esses astros até o ponto de entrarem em fusão. Nesse caso, átomos mais leves combinam-se para formar outros mais 
pesados. A diferença de massa, nessa conversão, é eliminada sob a forma de energia. É o que diz a fórmula de equivalência de massa e energia, a conhecida $E=m . C 2$.

Pronto. Em meia dúzia de passagens, a fonte de energia deixou o coração quente das estrelas para mover os olhos do leitor.

Pode-se discutir o futuro do Universo a partir da segunda lei da termodinâmica.

A segunda lei diz respeito à entropia, quantidade de desorganização de um sistema. Isaac Asimov escreveu um belo conto sobre entropia e morte do Universo em Nove Amanhãs. A pergunta contida no livro é se a entropia pode ser detida.

No cotidiano, temos uma visão equivocada de fluxo e fontes de energia.

A energia elétrica gerada por quedas d'água parece não ter relação com a energia nuclear, eólica, solar, das marés, ou a que mantém aquecido e brilhante o núcleo de galáxias e corpos poderosamente energéticos e distante, os quasares.

É uma visão enganosa. Segundo a cosmologia do Big Bang, toda a energia do Universo, originou-se da explosão primordial e não cessou de se transformar. O desafio da ciência é contar como tudo isso aconteceu.

Um átomo radioativo como o do urânio, utilizado em reatores nucleares ou em bombas atômicas, formou-se na fase final da vida de uma estrela de grande massa. $O$ artífice das supernovas, como essas estrelas são conhecidas, é a gravidade.

A gravidade cozinha pacientemente átomos simples nos caldeirões estelares até convertê-los em átomos densos e instáveis de matéria pesada. Quando a ruptura do núcleo, a fissão nuclear, libera a energia desses átomos, em reatores nucleares modernos, a água aquecida movimenta um gerador de energia elétrica. Como uma velha máquina a vapor tocada a carvão.

No interior solar, por fusão nuclear, 600 mil toneladas de hidrogênio são convertidos em hélio a cada segundo. Há uma diferença de massa, entre hidrogênio e hélio, eliminada sob forma de energia. Essa é a fonte que alimenta a vida na Terra.

Mas não só diretamente. $\mathrm{O}$ aquecimento da Terra dá origem a certos movimentos como as correntes marinhas e os ventos, além de vaporizar a água que formará a nascente dos rios. Contidas em grandes represas as águas têm sua energia potencial acumulada. Com essa força movimenta as turbinas de conversão de energia cinética, o movimento, em energia elétrica.

Os ventos encrespam as águas do mar e formam ondas que varrem praias e costões rochosos num movimento incessante. É possível retirar energia das correntes marinhas e das ondas e, no futuro, certamente faremos isso melhor que agora.

Com a energia das marés não é diferente. Durante muito tempo não se soube. Mas agora sabemos bem que a gravidade, neste caso a interação gravitacional entre a Terra, Sol e Lua, especialmente, é a fonte de energia que move as marés.

Há muitas outras fontes de energia, como a que movimenta a crosta quebrada da Terra e dá origem a vulcanismo, sismo e maremotos. Ainda assim, o que alimenta todas essas usinas é a energia da gravitacão universal.

\section{Fusão Nuclear: Alternativa para o futuro?}

\section{Marcelo Knobel}

Ao fundir núcleos atômicos leves (tais como os isótopos do hidrogênio, o deutério e o trítio) há uma enorme liberação de energia, processo que é conhecido como fusão atômica. Esse processo é similar ao que ocorre no interior do Sol e de outras estrelas, e poderá vir a ser uma fonte de energia ilimitada para gerações futuras. Para realizar fusões que efetivamente liberem grandes quantidades de energia é necessário que um gás formado pelos isótopos do Hidrogênio seja aquecido até temperaturas elevadíssimas (100 milhões de graus centígrados) e seja mantido confinado por pelo menos um segundo, o que pode ser conseguido usando confinamento magnético. Uma das configurações mais utilizadas é chamada tokamak, palavra russa que significa câmara magnética em forma de toróide.

Apesar dos enormes avanços na tecnologia e no entendimento dos fenômenos físicos que ocorrem durante a fusão nuclear, ainda não se tem certeza se o potencial da fusão nuclear poderá ser efetivamente realizado de uma maneira economicamente viável. Existem diversos programas, em diversos países, com um objetivo global de elevar a tecnologia de fusão a um estágio comercialmente aceitável para a geração de energia elétrica por volta de 2040-2050. Esses programas se baseiam em diversos estudos que indicam que nos meados do próximo século a 
demanda de energia elétrica será muito maior do que é hoje em dia, com o agravante da escassez de recursos fósseis (e das restrições ao seu uso por motivos ambientais).

De fato, a fusão nuclear apresenta uma vasta lista de qualidades de segurança ambiental. Não há reações em cadeia, e a radiotoxicidade dos detritos de uma planta de fusão nuclear é comparável à radiotoxicidade dos detritos provenientes de uma usina termo-elétrica. Os detritos não apresentam efeitos acumulativos para gerações futuras. Além disso, a fusão não produz mudanças climáticas ou emissões poluidoras da atmosfera. Entretanto, apesar de representar a possibilidade de conquistar uma fonte de energia inesgotável, com muitos benefícios para o nosso meio ambiente, as pesquisas em fusão nuclear não vem sendo suficientemente apoiadas, talvez devido aos enormes avanços de que ainda dependem e ao investimento considerável que essa inciativa representa.

\section{Cont.) Investimentos e Perspectivas futuras}

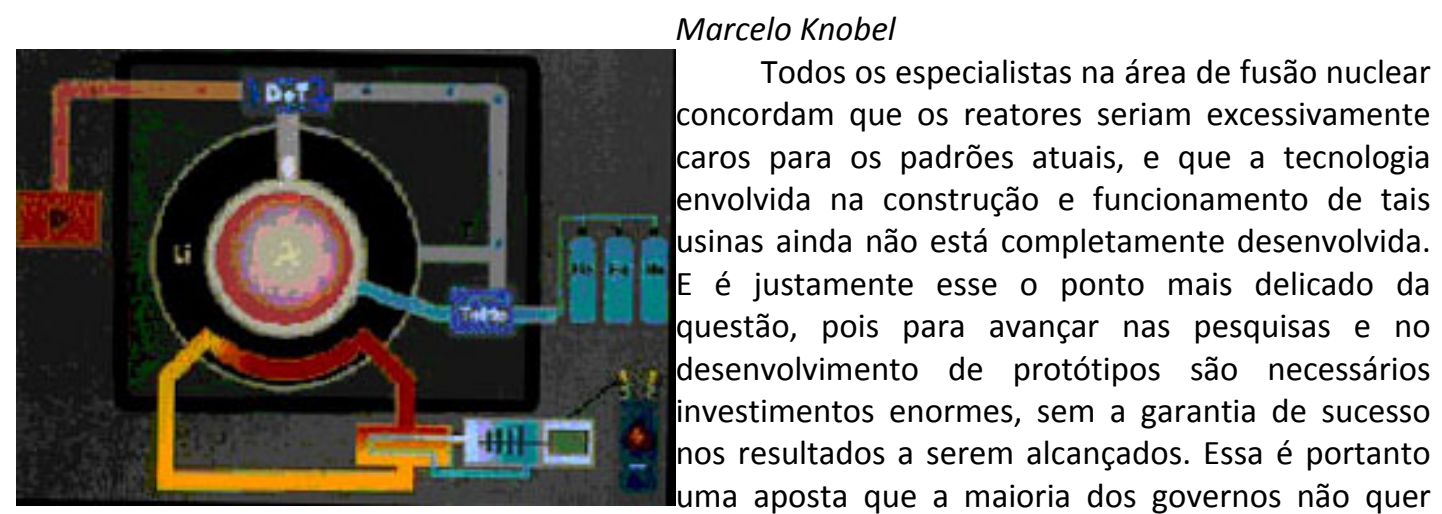
assumir, provavelmente sobrepujados pelas necessidades imediatistas e eleitorais dos economistas e políticos, pois resultados efetivos só seriam observados em cinqüenta, talvez sessenta anos. Por outro lado, mesmo insatisfeitos com os recursos até agora obtidos, os cientistas envolvidos com a fusão nuclear continuam a ser bastante otimistas, graças aos enormes avanços alcançados nas pesquisas nos últimos anos.

Permanece ainda a dúvida: vale a pena investir grandes quantidades de dinheiro nas pesquisas em fusão nuclear? A resposta, é claro, depende de previsões para o futuro, e por mais realistas que sejam, diferentes cenários imaginários podem levar a conclusões distintas. Por exemplo, além de ser uma fonte de energia limitada, se os cientistas concluírem que a queima de combustíveis fósseis está provocando de fato mudanças irreversíveis no clima da terra, temos que pensar urgentemente em soluções alternativas. Nessas alternativas podemos incluir as fontes de energia ditas renováveis (como hidroelétrica, solar, eólica, marés, geotérmica, biomassa etc...), a fissão e a fusão.

As fontes de energia renováveis serão cada vez mais importantes, mas não conseguirão suprir todas as necessidades globais, que vêm crescendo continuamente ano após ano. A fissão nuclear poderia suprir essas necessidades, mas tem as suas desvantagens óbvias com relação ao impacto ambiental. Considerando então esse cenário, a alternativa da fusão parece óbvia, mas o empecilho continua sendo econômico. De acordo com B.H. Ripin : "Então, a questão que realmente fica é a seguinte: Podemos nos arriscar a não perseguir vigorosamente a fusão? Uma nova usina nuclear custa entre 1 e 10 bilhões de dólares hoje em dia; uma nova geração de usinas custaria o total de 10 trilhões de dólares! O financiamento das pesquisas em fusão nuclear em torno de 1 bilhão de dólares por ano, mesmo por mais 50 anos, é uma aposta razoável? No meu entender, sim."

Mas também há muitos críticos sérios ao dispêndio de dinheiro com pesquisas em fusão, relacionados com a exiquibilidade e implementação de plantas nucleares, com os problemas de resíduos e proliferação, e com o seu custo total. Por exempo, Edwin Lyman, do Nuclear Control Institute, E.U.A., diz o seguinte: "É realmente um sonho regressivo tentar fazer a energia de fusão funcionar. Se algo como as dezenas de bilhões gastos na pesquisa e desenvolvimento de fusão tivesse ido para pesquisas em energias leves e renováveis, tais como solar e eólica, quem sabe onde estaríamos agora..."

Além dos custos, os governos devem lembrar-se que não se trata de uma simples aposta. Trata-se de investir no futuro da própria humanidade, tanto do ponto de vista energético, quanto 
da preservação do meio ambiente. Deve se manter, no mínimo, os investimentos necessários para sustentar a pesquisa em uma área tão interessante. Inúmeros exemplos na história da humanidade demonstraram que é extremamente difícil apostar no futuro, mas que a aposta em ciência básica quase sempre resulta em algo proveitoso, muitas vezes inimaginável no momento do nascimento das pesquisas naquela área.

Vale a pena destacar, neste ponto, as palavras, escritas em 1993, do eminente cientista John D. Lawson (especialista em fusão nuclear): "Estamos ainda longe do objetivo final? Tal como podemos conceber atualmente, mesmo com a demonstração do ponto de vista físico e técnico que se espera do ITER, um reator de fusão confiável seria tão complexo que segundo os critérios econômicos atuais seria classificado "não-econômico". Nesta altura é difícil de prever quando a investigação sobre fusão chegará ao fim e poderá fornecer uma contribuição crucial para as necessidades da humanidade.

Seguramente, se pudermos imaginar um mundo tecnológico apoiado, estável, onde as crises políticas e ambientais atuais estejam controladas razoavelmente, então a satisfação de nossas necessidades de energia através da fusão poderá ser um ingrediente essencial do mundo futuro. É uma opção que devemos com certeza manter em aberto para os próximos anos"

Leia a íntegra do artigo de Marcelo Knobel

\section{CLONAGEM}

\section{Clonagem ainda é técnica em desenvolvimento}

A clonagem tem causado inflamadas discussões em toda sociedade, principalmente quando essa técnica, já empregada em bactérias, plantas e animais, passou a vislumbrar o ser humano. Originada da palavra grega klón que significa broto vegetal, essa técnica é basicamente uma forma de reprodução assexuada (sem a união do óvulo e do espermatozóide) e que origina indivíduos com genoma idêntico ao do organismo provedor do DNA. A medida que a técnica foi se aproximando da árvore geneológica da evolução humana passou a representar uma ameaça dada a possibilidade de serem geradas crianças idênticas ao pai ou a mãe.

A idéia de clonagem surgiu em 1938 quando Hans Spermann, embriologista alemão (Nobel de Medicina, 1935) propôs um experimento que consistia em transferir o núcleo de uma célula em estágio tardio de desenvolvimento para um óvulo. Em 1952, Robert Briggs e Thomas King, da Filadélfia, realizam a primeira clonagem de sapos a partir de células embrionárias. Em 1984, Steen Willadsen da Universidade de Cambridge clonou uma ovelha a partir de células embrionárias jovens. Um grupo de pesquisadores da Universidade de Wisconsin clonou uma vaca a partir de células embrionárias jovens do mesmo animal (1986). Em 1995, lan Wilmut e Keith Campbell, da estação de reprodução animal na Escócia, partiram de células embrionárias de 9 dias para clonar duas ovelhas idênticas chamadas de "Megan" e "Morag". No ano seguinte surgiu "Dolly", clonada pelas mãos destes mesmos pesquisadores a partir de células congeladas de uma ovelha. Esta foi a grande inovação - e que criou a grande repercussão do caso-, um clone originado não de uma célula embrionária, mas sim de uma célula mamária. Em 1997, Dolly teria seu nascimento anunciado, sendo o marco de uma nova era biotecnológica.

Posteriormente à ovelha mais famosa do mundo surgiram clones de bezerros, cabras, camundongos, porcos e macaco rhesus. Hoje a corrida tecnológica da clonagem tem como países líderes os Estados Unidos, Escócia, Inglaterra, Japão, Nova Zelândia e Canadá.

Os procedimentos mais utilizados em animais e que começam a ser usados em clonagem de humanos são dois: um deles consiste em utilizar o material genético (núcleo) extraído de uma célula não reprodutiva ou somática (diferente do óvulo ou espermatozóide) de um indivíduo e inseri-lo em um óvulo cujo núcleo com DNA tenha sido retirado. Essa célula pode ser originada de um embrião, feto ou adulto que estejam vivos, mantidos em cultura em um laboratório ou de tecido que esteja congelado.

A outra técnica consiste na fusão de uma célula inteira com um óvulo sem material genético. Foi essa justamente a técnica utilizada em Dolly. Sua fase crítica - em que o experimento pode não dar certo -se dá na etapa de fusão das células, feita através de corrente elétrica ou com um vírus chamado Sendai (veja esquema abaixo). 
1) As células somáticas são retiradas do doador 2) Essas células são cultivadas em laboratório 3) De uma doadora colhe-se um óvulo não fertilizado 4) O núcleo contendo DNA é retirado do óvulo 5) A célula cultivada é fundida ao óvulo por meio de corrente elétrica 6) Agora temos o óvulo fertilizado com nova informação genética 7) Este óvulo vai se desenvolver até a fase de blástula (embrião com mais de 100 células) onde estão as células tronco.

A clonagem de animais no Brasil foi iniciada em março de 2001 com o nascimento de Vitória, uma bezerra da raça simental desenvolvida pela equipe de Rodolfo Rumpf, coordenador do projeto de biotecnologia de reprodução animal da Embrapa. De lá pra cá, nenhum outro animal foi clonado, embora alguns grupos venham desenvolvendo pesquisa, principalmente em clonagem de bezerros. Esses animais são escolhidos por terem apelo comercial e por terem um período de gestação longo o que gera, normalmente, apenas um indivíduo. O fato de originar, através dos métodos naturais, apenas um indivíduo por gestação dificulta a perpetuação de algumas características que são interessantes para o comércio, como por exemplo uma maior produção de leite ou a alta taxa de músculos. A clonagem de bovinos poderia facilitar a reprodução de animais com certas características genéticas. Para os galináceos, que podem se reproduzir em um período curto de tempo e gerar inúmeros indivíduos, a clonagem não seria tão interessante.

Mas existe também a possibilidade de animais serem clonados para fins terapêuticos, servindo para a experimentação ou visando a produção de órgãos compatíveis com o ser humano animais poderiam ser, um dia, produzidos em série para transplantes. Algumas empresas, como a Advanced Cell Technology (ACT), a mesma que alegou ter clonado o primeiro embrião humano da história, já dispõe de um banco de tecidos para quem quiser guardar amostras de seu bichinho de estimação ou de animais com grande potencial pecuário. Quando a técnica de clonagem estiver bem estabelecida esse material poderia ser utilizado.

A idéia de produzir clones de animais de estimação por enquanto só é possível em filmes como O Sexto Dia, estrelado por Arnold Schwarzenegger. Na história, o cachorro do personagem de Schwarzenegger é clonado por uma empresa chamada Re-pet, especializada em animais de estimação.

No entanto, bancos como esses começam a ser formados também para animais em extinção como o Centro de Reprodução de Espécies em Extinção do Zoológico de São Diego (EUA) e o Centro para Pesquisa de Espécies em Extinção do Instituto Audubon (EUA). A idéia é que, no futuro, o material genético de animais ameaçados de desaparecer possa ser usado para cloná-los e reproduzí-los.

A ACT chegou a clonar, em 2000, um gauro, espécie em extinção semelhante ao boi, natural da Índia, Indoshina e parte da Ásia. O animal fora clonado a partir de células da pele de um gauro fundidas com óvulos de vacas. Mas após nove meses de gestação o animal morreu, pouco depois de nascer, devido a complicações no sistema respiratório.

A espectativa é que a clonagem seja a única alternativa para recuperar espécies já extintas como o tigre da Tasmânia (desaparecido desde 1930) e o bode bucardo da montanha (desaparecido desde 2000). Outras espécies em vias de extinção como a ararinha-azul, o mico-leão-dourado, o peixe-boi, o pirarucú, a sussuarana, o lobo-guará, a lontra e o tamanduá-bandeira também poderiam ser clonados. Existe, porém, a preocupação para que o material armazenado desses animais tenha variabilidade genética para que não sejam originadas populações tão homogêneas que correriam o risco de serem dizimadas por vírus e bactérias. $\mathrm{O}$ armazenamento de amostras de células do maior número de animais de uma espécie que ainda estejam disponíveis no mundo, poderia garantir indivíduos com menor igualdade genética.

Atualmente, é impossível utilizar DNA extraído de organismos preservados em âmbar (como sugere o filme de Steven Spielberg $O$ Parque dos Dinossauros), de células congeladas em condições diferentes às exigidas por condições laboratoriais, células de cadáveres ou de material fossilizado.

Entre os grupos brasileiros atuantes no campo da clonagem animal estão, segundo Rodolfo Rumpf, da Embrapa, o coordenado por José Antônio Visintin na Veterinária da USP; o de Joaquim Mansano Garcia na Unesp de Jaboticabal; o de Flávio Meireles na USP de Pirassununga e outros que ainda estão se estruturando, além do grupo liderado pelo próprio Rumpf. Entre os que estão em processo de estruturação está o grupo liderado por Reginaldo Fontes na Universidade Estadual Norte Fluminense, o coordenado por Otávio M. Ohashi na Universidade Federal do Pará, e grupos no Rio Grande do Sul. 
No que se refere à clonagem humana, os maiores benefícios esperados pela comunidade científica estão no campo da terapia de órgãos e tecidos. É através dessa técnica que pesquisadores esperam estudar as chamadas células-tronco (células primordiais no embrião que têm multipotencialidade para gerar os mais de 200 tipos celulares do nosso corpo) que poderiam gerar células cardíacas, hepáticas, hemácias, epiteliais e resolver ou amenizar problemas causados por enfarto, cirrose, leucemia e queimaduras da pele. Embora a impressão que se tem através dos jornais é que esse processo é relativamente simples, Paulo Marcelo Perin, do Centro de Reprodução Humana de Campinas, garante que a técnica ainda não existe: "não sabemos o que vai ser necessário para reconstituir um rim inteiro".

No Brasil, muito se tem feito no ramo de pesquisas com células-tronco adultas, extraídas do cordão-umbilical de bebês ou da nossa medula mas, segundo informa Perin, essas células já sofreram algum processo de diferenciação e, portanto, têm potencial restrito para se transformarem em outros tipos celulares. Por isso as células-tronco cultivadas a partir de células retiradas de embriões despertam mais interesse, embora sejam muito mais polêmicas. "Esse é o grande dilema ético, porque estaríamos produzindo embriões exclusivamente para fins terapêuticos", explica Perin. O que é vida para grupos religiosos é apenas um emaranhado de células para os cientistas.

Mas a polêmica mais efervescente é aquela que permeia a reprodução humana. Se ela hoje depende fundamentalmente de um espermatozóide e um óvulo, poderá se tornar independente ao ponto de qualquer célula de nosso corpo poder fecundar um óvulo e gerar um descendente. Claro que contando com o auxílio de um bom laboratório e alguns milhares de reais. Para Perin, a clonagem humana parece interessante para casais que não produzem células reprodutivas (óvulos ou espermatozóides). Ele acredita que as técnicas de clonagem serviram muito mais para resolver outros problemas de fertilidade do que para gerar cópias de seres humanos. Cita como exemplo uma técnica realizada por um grupo de pesquisadores do Centro de Monash, na Austrália, que a partir de uma célula somática de um camundongo (que possui dois conjuntos de cromossomos ao invés de apenas um como em uma célula reprodutiva), deixou apenas um conjunto de cromossomos e fertilizou um óvulo, de uma doadora da mesma espécie, com a célula que funcionou como um espermatozóide.

A técnica de clonagem ainda está em aperfeiçoamento. A alta taxa de mortalidade em experimentos com animais - cerca de $90 \%$-, diagnósticos pré-implantacionais (antes do útero) e pré-natais, ainda em definição, alarmam para o fato de ninguém saber determinar a normalidade dos embriões. "Do ponto de vista científico a clonagem humana é inevitável, mas não sei se a sociedade como um todo vai permitir que isso aconteça, porque a ciência avança e não pensa nas consequências, o avanço é feito. Mas quem impõe os limites é a sociedade. Os aspectos jurídicos, morais, religiosos vão ser determinados pela sociedade", conclui Perin.

\section{Humanos ao Amanhecer Ulisses Capozoli}

Se a ficção científica for lida como história do futuro, a clonagem humana é um evento tão previsível como o próximo eclipse do Sol. As evidências disso estão no passado. Durante o século 18, a idade de ouro dos autômatos, tentou-se, com base em recursos de relojoaria, forjar criaturas capazes de repetir os mínimos movimentos de homens e animais. Foi um esforço mecânico na reprodução da Natureza.

Pode parecer ingênuo, mas a verdade é que engenho e arte combinaram-se com resultados surpreendentes. Na França, Jacques de Vaucanson (1709-1790) foi um dos construtores de seres artificiais. Seu famoso pato encantou os visitantes da exposição de Paris, em 1738 . O animal mecânico de Vaucanson imitava todos os movimentos de um pato natural, incluindo a alimentação e apenas uma asa tinha mais de 400 peças articuladas. Além do pato, seu tocador de flautas era capaz de executar doze diferentes trechos musicais.

Vaucanson foi apenas um, num conjunto crescente de criadores de autômatos, como Joseph Faber (1800-1850) ou Thomas Edison (1847-1931), o conhecido inventor norte-americano, pai da lâmpada elétrica incandescente.

As criaturas mecânicas de Faber faziam perguntas e ofereciam as respostas. As bonecas falantes de Edison encantaram adultos mais que crianças. Um "homem-vapor", desenvolvido em 
1893 por um certo George Moore, caminhava com o dobro da velocidade de um humano: 14 quilômetros por hora. No século 17, um oficial conhecido por De Gennes construiu um pavão que tanto caminhava, como o homem de Moore, como ingeria alimentos, caso do pato de Vaucanson.

Como acontecia nos navios, onde boa parte dos comandantes tinha, em sua cabine, uma mulher-boneco, a "mulher do capitão", para satisfazer seus desejos em alto-mar, também em terra, no libertino século 18, foram desenvolvidos autômatos com finalidades sexuais. Tudo isso animado pelos movimentos de um árvore dentada, peça talhada para produzir uma seqüência de movimentos previamente definidos num sistema de engrenagens.

Talvez valha a pena lembrar que no século 18 um legado cartesiano descrevia o mundo como um gigantesco mecanismo de relojoaria. Era a cosmologia da época. E cosmologia, mais que uma descrição de como o Universo nasceu e evolui, é a imagem que cada época plasma da experiência de estar no mundo.

$\mathrm{O}$ ataque mais agressivo à cosmologia mecânica do cartesianismo foi feito por Isaac Newton, com a gravitação universal. Um sistema mecânico não combina com forças agindo à distância, sem qualquer materialidade aparente, caso da gravitação.

A criação de seres artificiais tem sido naturalmente associada, por historiadores da ciência, ao desenvolvimento dos computadores, no século 20. Mas, certamente, pode-se encontrar aí também um sinal da solidão humana. Pigmaleão, jovem rei de Chipre, segundo relata Ovídio, moldou, com as próprias mãos, uma estátua de marfim pela qual apaixonou-se. Seu sofrimento só foi contido pela intervenção de Afrodite, deusa do amor, que deu vida à criação.

Ao concluir a escultura de David, Michelangelo ordenou que falasse. Como muitos, ele também escolheu a palavra para humanizar inteiramente suas criações. Se essas obras, por muitas razões, não fossem todas portadoras de uma poderosa atração, como entender a estranha emoção de se aproximar da Pietá?

Não só o passado recente, mas também a antiguidade, estão povoados de seres artificiais, mostra o historiador da ciência francês Philippe Breton. Homero localiza em llíada a presença de "criadas de ouro" que ajudavam Hefaistos, o deus aleijado a caminhar. E Hefaistos, com sua insuspeita restrição física, é um criador de seres artificiais, trabalho que executa em parceria com a deusa Atena, protetora da guerra, das armas e da tecelagem.

Dédalo, o famoso escultor cretense do século 7 antes de Cristo, foi um dos precursores mais remotos do que, possivelmente venham a ser, num futuro próximo, as clonagens humanas. Suas estátuas, com olhos abertos, pernas bem separadas para caracterizar movimento, braços estendidos, desfrutavam da crença de poderem andar.

Breton divide as criaturas artificiais em duas diferentes famílias: as que realizam trabalho pesado e as supervisoras. São os ancestrais dos robôs industriais e dos sistemas de controle de qualidade. Além delas, refere-se aos homúnculos e aos seres lógicos. Os homúnculos permitem que seus criadores, masculinos, possam dispensar as mulheres para a continuidade da espécie. Os seres lógicos são os avós dos computadores.

Como ocorreu com o jovem rei de Chipre, a criação de mulheres artificiais tem sido um tema recorrente na ficção científica, tanto em livro como no cinema. Neste caso, longe de se tratar de pura misoginia, é uma evidência da profunda solidão humana.

Phillipus Aureolus Theophrastus Bombastus von Holenhein, o Paracelsus, médico e alquimista suiço (1493-1541) foi um dos que se esforçaram para assegurar a reprodução fora do útero materno. Seus homúnculus são anões de aparência desagradável com acesso a conhecimentos vedados à condição humana. São gerados por uma combinação de esperma e sangue, segundo uma velha tradição, partilhada por Aristóteles e Plínio, baseada na idéia de que toda espécie humana teve origem nos rins do primeiro homem ou no ovário da primeira mulher.

Quanto ao futuro e os relatos da ficção científica, a obra mais perturbadora sobre clonagem humana certamente é a novela de Philip Dick que Ridley Scott levou para o cinema, em 1982 com o título de Blade Runner - o Caçador de Andróides. Na história, o blade runner Deckard está encarregado da eliminação de andróides que retornam à Terra para ampliar seus curtos períodos de vida. O filme teve, curiosamente, duas versões. Em ambas, Deckard apaixona-se por uma andróide e foge com ela para o desconhecido. Numa nelas, fica a forte impressão de que ele mesmo é um andróide.

Robert Heinlein (1907-1988) autor de Stranger in a Strange Land, em 1958, escreveu Methuselah's Children. O caso envolve as "famílias Howard", um grupo de 100 mil pessoas 
beneficiadas, por experiências genéticas, a chegarem aos 150 anos de idade. Desmascarados em 2125, devem partilhar este privilégio com os demais.

Ao tratar da longevidade, via manipulação genética, Heinlein se aproxima do universo de Philip Dick, onde o útero humano foi, definitivamente, transferido para o laboratório.

Religiosos e bioéticos, por razões diferentes, compreensíveis e necessárias, estão na linha de frente do combate ou, no segundo caso, ao menos numa condução humanista para as pesquisas científicas relacionadas à clonagem. Religiosos, de uma maneira geral, têm contra si o fato de sustentarem, quase sempre, uma verdade definitiva para o mundo. Isso levou à proibição de investigações anatômicas, ao longo de praticamente toda a Idade Média, período em que, no Ocidente, a racionalidade cedeu espaço à teologia.

Os bioéticos estão numa posição delicada. Devem enxergar o futuro além dos condicionamentos especialmente religiosos de hoje que, longe de refletir uma preocupação com a humanidade do homem, temem que suas construções, algo definitivas, desabem mais uma vez.

Se a questão da humanidade dos homens for posta a nu, para uma reflexão profundamente necessária, então a partilha das riquezas da Terra deveria ser a primeira providência para se eliminar injustiças inaceitáveis num certo estágio de civilização. Quando pode-se, por exemplo, construir radiotelescópios e assim entrar em contato com outras possíveis inteligências da Galáxia. Neste caso, um continente inteiro, como a África, teria seu sofrimento amenizado pelo conhecimento da ciência. Esse seria um passo de sete-léguas em direção à humanização do homem, livre de sofrimentos antigos como a fome, a sede e o frio. À ciência cabe diminuir o sofrimento humano e não eliminar sua solidão, um sentimento que nasceu com o homem e deverá acompanhá-lo até o fim.

Perguntas ingênuas querem saber se o clone de alguém é ele próprio. Como isso poderia ser possível? Qualquer identidade só pode resultar de um processo histórico, específico a cada um dos fenômenos do mundo. No caso de um clone, um fato histórico fundamental é que que se trata de um clone. Este é o ponto de partida, ou de chegada, faz pouca diferença.

Mas isso, de forma alguma, deve sugerir que um clone seja menos humano. A novela de Philip Dick, ele próprio um atormentado solitário, é o melhor argumento para este ponto de vista. Os humanos, de uma ou outra maneira, são todos clonados pelo tempo por processos que transformaram órgãos inteiros, como patas em mãos, tendo como fonte de energia a sexualidade. Até agora, a Natureza foi a única responsável por esticar tendões, reconfigurar músculos, eliminar apêndices dispensáveis e substituir peles antigas, grossas e peludas do corpo humano. A partir de agora, a ciência também pode aprender a fazer isso: redesenhar o homem.

A reconfiguração do homem tem muitos precedentes históricos preocupantes. Mas acenar com os riscos do passado, para negar o futuro, certamente não é a melhor maneira de se conduzir. As futuras viagens espaciais, ainda neste século, vão exigir novas condições de suas tripulações. A pergunta, neste caso, é se é mais humano enviar nessas longas jornadas pelo espaço -- em condições de imponderabilidade, que esfacelam músculos, estruturas ósseas e resistência cardíaca - tripulações geneticamente adaptadas ou tripulações, digamos, convencionais.

Tanto o papa quanto o presidente norte-americano, George W. Bush, já se disseram contrários à clonagem e, em quase todo o mundo, os congressos criam leis para tentar vetar essa possibilidade. Se a palavra do papa bastasse, Galileu não teria existido enquanto um dos fundadores da ciência moderna, essa mesma que quer reproduzir o homem. Quanto ao presidente dos Estados Unidos, nem sempre um cowboy tem a última palavra. Em relação aos congressos, desde a divisão dos poderes proposta por Montesquieu, em 1748, a função do legislativo é auscultar e atender às necessidades de novas demandas sociais. Ao menos nas sociedades democráticas. E isso implica em uma constante mudança de posição.

Uma cobertura um tanto sensacionalista da mídia interpreta a clonagem humana com um divisor de épocas, como o início de uma nova era. Talvez venha a ser assim. De qualquer forma, a história continua e, neste caso, a reprodução do homem pelo homem será apenas mais uma manifestação do novo.

O horizonte de eventos, de qualquer maneira, como sempre, estará repleto de possibilidades. Uma delas deve ser as máquinas de von Neumann, mecanismos capazes de executar suas próprias concepções e desenvolvimento. Qual o limite que uma máquina, um autômato, um robô, pode atingir? No conto A Sentinela, que deu origem ao 2001, Uma Odisséia no Espaço, Arthur Charles Clarke confere sentimentos bem humanos a HAL, o computador de bordo. 
A fusão homem-máquina, outro dos arquétipos recorrentes na ficção científica, certamente é ainda mais embaraçosa que a clonagem bioquímica. Mas nenhuma delas pode ser considerada como uma dessacralização do mundo. Este acontecimento, na verdade, se deu há quase 400 anos, quando Francis Bacon recomendou o domínio da natureza. O mecanicismo reduziu a mitologia à época de uma pretensa ingenuidade humana, como se agora vivêssemos a plenitude dos tempos.

Os clones podem ser o início de uma nova era, com alterações radicais no nascimento e morte, os dois extremos da vida. Mas, neste amanhecer ainda seremos humanos. Ao menos foi essa a promessa que nos fez Philip Dick.

Ulisses Capozoli é jornalista especializado em divulgação científica é mestre e doutorando em ciências pela USP e presidente da Associação Brasileira de Jornalismo Científico (ABJC)

\section{Clones na mídia}

Hélio Schwartsman

No último dia 25, a empresa de biotecnologia norte-americana Advanced Cell Technology (ACT) anunciou a criação do primeiro clone humano. O embrião, que foi gerado para pesquisa de doenças, deixou de multiplicar-se quando contava com seis células.

Há certamente algum exagero em apregoar como primeira clonagem humana um emaranhado de células ainda anterior a um blastocisto. E vale lembrar que a divulgação não seguiu a rota canônica. Ela não foi feita através das principais publicações científicas com peer review, mas por dois veículos leigos (Scientific American e U.S. News \& World Report) e por uma obscura revista científica eletrônica (Journal of Regenerative Medicine). Fica a sensação de que a ACT quer ganhar a corrida da clonagem "no grito". Estão em jogo patentes e mercados potencialmente milionários. Não duvido de que, para a história, o 25 de novembro de 2001 prevaleça como data da primeira clonagem humana, ainda que esse tenha sido muito mais um feito de mídia do que de ciência propriamente dita.

E a notícia, como notícia, é boa. A clonagem desencadeia fortes reações emocionais e dá margem a polêmicas acres. Isso "vende jornal". Mesmo assim, não seria exato afirmar que o anúncio da primeira clonagem humana apanhou a imprensa de calças curtas. Todo mundo sabia que era uma questão de tempo até que alguém arriscasse produzir um embrião humano por técnicas de transferência nuclear. Assim como é uma questão de tempo até que alguém produza um clone e o implante num útero para que se desenvolva até tornar-se uma pessoa.

A ACT assegura que jamais teve a intenção de produzir réplicas humanas. Todos os esforços, afirma a empresa, estão voltados para a clonagem terapêutica, a produção de células-tronco (com capacidade de converter-se em vários tipos de tecido) para ser usadas no tratamento de uma série de moléstias.

Como é frequente nas ciências, a técnica avança mais rapidamente do que o consenso sobre o que é ético e o que não é. Para tentar mapear a polêmica e entender melhor o papel da imprensa nesse imbróglio - meu propósito neste artigo -, precisamos, antes de mais nada, perguntar para que serve a clonagem.

A resposta mais óbvia é: "para fins terapêuticos". Nesse caso, a idéia é gerar células-tronco, isto é, células indiferenciadas, formadas nos primeiros estágios da divisão do embrião. Elas têm a capacidade única de converter-se em qualquer tipo de tecido, neurônio, osso ou pele. Em princípio, possibilitam o desenvolvimento de novas terapias para várias doenças degenerativas e até para reparar órgãos com defeito. Por enquanto, a clonagem terapêutica não passa de uma promessa, talvez até "inflada" pelos interessados. Mesmo assim, seria temerário ignorar esse campo de investigação.

A clonagem garantiria que as células utilizadas seriam $100 \%$ compatíveis com as do paciente, eliminando o problema da rejeição. Esse tipo de utilização, vale reforçar, não exige o desenvolvimento completo do embrião, que seria descartado poucos dias depois da "concepção".

A maioria das associações de cientistas dos EUA e da Europa defende esse tipo de pesquisa. A oposição fica por conta do Vaticano e dos grupos conservadores de sempre. Admito que minha exposição talvez peque por ser excessivamente utilitarista, mas acho que ela se sustenta. Quem não se opõe ao aborto não teria muitas razões para ser contra esse gênero de investigação.

O debate fica intelectualmente mais estimulante quando se considera a clonagem reprodutiva, isto é, com vistas a gerar um novo ser humano. No imaginário popular, a clonagem ofereceria a chave para a imortalidade, ao tornar possível a criação de cópias fiéis de um determinado indivíduo. Só que aqui o desejo fala bem mais alto do que os fatos. Um clone gerado a 
partir de um adulto não é absolutamente um alter ego, um "mini-eu". Ele é antes um irmão gêmeo univitelino, só que muitos anos mais novo. Talvez um pouco menos. Sem ser submetido ao mesmo ambiente, uma impossibilidade prática, ele se pareceria ainda menos com o original do que um gêmeo "normal" criado na mesma família.

Para que se possa pensar em imortalidade ou algo semelhante, seria preciso encontrar uma forma de transferir as memórias e a personalidade para esse corpo mais jovem. Embora elas ocorram sobre uma base físico-química, conservam uma imaterialidade essencial. A memória está no cérebro, mas, até onde vai nosso conhecimento, é algo muito diverso de um determinado grupo de neurônios e substâncias químicas. $E$, no fundo, quando falamos em imortalidade, pensamos mais em memórias e personalidade do que no corpo propriamente dito.

Até onde consigo ver, clonar e gestar um ser humano não serviria para muita coisa. Existe, é claro, um público cativo, composto normalmente de personalidades narcísicas (Schwarzenegger é candidato) ou pessoas que estão em processo de luto, como pais que pretendam "recriar" um bebê morto. Fala-se também em utilizar a clonagem para permitir que homens inférteis tenham "filhos" biológicos. Só que esses "filhos" não seriam exatamente filhos, mas uma cópia cuja relação de parentesco com o original ainda não tem nome.

Alguns grupos já iniciaram os preparativos para tentar criar um ser humano por clonagem. Em comum, têm o fato de serem outsiders, que parecem mais interessados em propaganda e lucros fáceis ou em simplesmente dar vazão a crenças exóticas.

Um deles é a seita dos raëlianos. Querem "trazer de novo à vida" um bebê que morreu poucos anos atrás. Os raëlianos afirmam, entre outras temeridades, que a vida na Terra foi trazida por discos voadores.

Outro grupo é liderado por Severino Antinori, médico, proprietário de uma clínica de fertilidade na Itália e que gosta de aparecer na imprensa. Já ganhou manchetes fazendo uma mulher de 62 anos dar à luz.

Acho precipitado afirmarmos desde já e com todas as letras que a clonagem de um ser humano com fins reprodutivos deva, do ponto de vista ético, ser proibida para sempre. Uma decisão tão drástica exige mais debates. Mas podemos afirmar com toda a certeza que ainda é cedo para tentá-la. Insistir no projeto pode trazer graves implicações, que beiram a irresponsabilidade. As técnicas ainda não são boas o bastante. 0 índice de sucesso com mamíferos é da ordem de $1 \%$ ou $2 \%$. Isso significa que é necessário produzir de 50 a 100 embriões para obter um único nascimento. Como se não bastasse, são altas as taxas de animais que nascem com anomalias graves. Um bezerro ou uma ovelha podem ser sacrificados; um ser humano, não.

Precisamos, contudo, tomar cuidado para que o debate não se torne excessivamente técnico, centrando-se na segurança do método e não em suas implicações sociais e até ontológicas. Mesmo que o procedimento se torne $100 \%$ seguro, caberá a reflexão filosófica em relação a sua realização ou não com seres humanos. A discussão ética deve ser anterior à técnica, princípio nem sempre observado.

Vale registrar que a clonagem não é o único avanço biotecnológico que enseja dilemas éticos. A partenogênese, por exemplo, já chamada de "concepção imaculada", na qual o óvulo é levado a transformar-se em embrião sem nenhum tipo de fertilização, desperta mais ou menos as mesmas questões.

Vários países já elaboraram ou estão elaborando leis para regular biotecnologias. Elas dificilmente vão conter as "forças de mercado" que procuram veios lucrativos na biologia. Da mesma forma que existem paraísos fiscais, deverão surgir paraísos genéticos, onde pesquisadores poderão fazer o que bem entenderem. Cita-se muito a China e a Coréia do Sul como países que já despontam como "liberais" na regulação de biotecnologias. Embora eu considere as leis necessárias, não creio que sejam elas que funcionarão como principal freio a abusos. Além de paraísos genéticos, há a própria dificuldade natural de levar agentes da lei aos recônditos dos laboratórios e clínicas de reprodução. A barreira mais efetiva - e mesmo assim pouco efetiva deverá ser alguma forma de consenso de médicos e cientistas em relação ao que é ético.

Termino agora por onde deveria ter começado. Qual é o papel da imprensa nessa confusão toda?

Uma das principais funções dos jornais é informar o leitor de "novidades". Mas jornalistas são seres humanos, e seres humanos, quando têm de lidar com novidades, frequentemente se atrapalham. A ciência e o jornalismo científico, apesar de operarem principalmente com categorias racionais, não constituem exceção. Não escapam a deslizes e trapalhadas. O caso da clonagem é 
eloqüente. Embora sapos sejam clonados há décadas, a imprensa não-especializada descobriu o tema em 1997, com o anúncio da existência da ovelha Dolly.

$\mathrm{Na}$ ocasião, jornais de todo o mundo dedicaram páginas e mais páginas ao assunto. Evidentemente, havia pautas para todos os gostos. As editorias de ciência procuraram explicar os aspectos técnicos da clonagem. Articulistas e editorialistas se puseram a discutir as questões éticas que a nova tecnologia colocava. Colunistas com pendores de ficcionista deram rédeas livres à imaginação. Entre mortos e feridos, o público pôde informar-se sobre a novidade, mas, como sempre ocorre, também se deparou com muita bobagem.

Ler com os olhos de hoje as notícias científicas - e não tão científicas - do passado pode dar ocasião a boas gargalhadas. Nos anos 60 , padres discutiam se a inseminação artificial por esperma que não o do marido configuraria adultério. Nos 70, escritores, cientistas e advogados, além do Vaticano, condenavam os primeiros experimentos com bebês de proveta. Afirmavam que o método geraria monstros, acabaria com o amor e criaria exércitos de robôs, entre outras sandices. Em 1973, a Justiça de Nova York embrenhou-se em apaixonante debate jurídico para determinar se a inseminação artificial produz filhos legítimos.

É claro que, do outro lado, avanços técnicos provocaram desastres para a humanidade. Efeito estufa, buraco na camada de ozônio e Tchernobil são exemplos contundentes.

Hoje nós provavelmente estamos escrevendo algumas das besteiras "científicas" das quais nossos filhos um dia se rirão, mas podemos também estar criando o começo daquilo que um dia eles amaldiçoarão. Como o que se imprime agora sobre a clonagem humana acaba exercendo significativa influência sobre seu futuro, a imprensa tem grande responsabilidade. Legisladores e até cientistas acabam formando suas convicções com base no que lêem, tanto em publicações especializadas como nas mais gerais.

Gostemos ou não, opera aqui um pouco daquilo que Hegel chamava de ideologia (falsa consciência). "Grosso modo", importa menos como cada indivíduo pensa o mundo e muito mais como todos o pensam. E jornais, gostemos ou não, ajudam a formar essa consciência coletiva, enganosa e enganada, moldada pelo mundo, mas que também o molda.

Hélio Schwartsman é jornalista.

\section{Nada contra a clonagem}

\section{Bernardo Beiguelman}

A palavra clone foi criada em Biologia para designar indivíduos que se originam de outros por reprodução assexuada. A clonagem, que é o nome que se dá à formação de clones, é o meio de reprodução mais freqüente e natural dos vegetais inferiores, mas as plantas superiores também podem se multiplicar desse modo, como é o caso da grama dos jardins, que geram plantas independentes ao formarem raízes nos nós dos ramos laterais junto à terra. Às vezes, como acontece com a bananeira e, geralmente, com a parreira e com a cana de açúcar, a clonagem é o único meio de multiplicação de uma planta. Quando um jardineiro obtém mudas de begônia a partir de uma folha ou usa estacas cortadas dos ramos de uma roseira, para conseguir mudas plantadas ou enxertadas, ele está praticando clonagem. Aliás, foi dessa prática que surgiu o termo clone, porque, em grego, klón significa estaca.

A clonagem também ocorre naturalmente em animais, inclusive na espécie humana. De fato, em todas as populações humanas, tem-se que, de cada mil nascimentos, em média, quatro são de pares de gêmeos denominados univitelinos ou monozigóticos, porque se originam de um único ovo ou zigoto. Assim, em vez de o zigoto originar um único indivíduo, tem-se que, nos primeiros estágios do desenvolvimento embrionário, entre um e 14 dias após a formação do zigoto, ocorre uma subdivisão que dá origem a dois indivíduos. Essa subdivisão é, pois, uma reprodução assexuada. Por terem essa origem, os gêmeos monozigóticos são, indiscutivelmente, clones e, regra geral, geneticamente idênticos.

É essa identidade que faz com que os gêmeos monozigóticos sejam do mesmo sexo, isto é, pares do sexo masculino ou do sexo feminino. O nascimento de trigêmeos monozigóticos é bem menos freqüente e, mais raramente ainda, nascem tetragêmeos ou quíntuplos monozigóticos. Esses clones humanos naturais não devem, entretanto, ser confundidos com os gêmeos que resultam de poliovulação e que, por isso, não são necessariamente concordantes quanto ao sexo e podem ser dizigóticos, trizigóticos, tetrazigóticos etc., conforme se originem de dois, três, quatro etc. zigotos distintos. 
Dissemos acima que os gêmeos monozigóticos têm, regra geral, o mesmo patrimônio genético (genótipo). Por que regra geral? Porque durante qualquer reprodução assexuada pode ocorrer alguma alteração do material genético (mutação), resultando um ser com genótipo um pouco diferente daquele presente no ser original. Mas, na ausência de mutação, os gêmeos monozigóticos, do mesmo modo que outros clones são geneticamente idênticos. Essa identidade genética, entretanto, não significa identidade na aparência física ou psicológica, porque todo o ser vivo é o resultado da interação da sua constituição genética com o ambiente e é por isso que os gêmeos monozigóticos têm aparência física semelhante, mas não são fisicamente idênticos, além do que, eles apresentam individualidade psicológica. Parece interessante insistir nesse detalhe porque, lamentavelmente, existe uma tendência generalizada de enfatizar apenas a importância da constituição genética das pessoas e de menosprezar o efeito do ambiente, como se o ser humano não fosse mais do que o seu genótipo! Tudo na sociedade humana, inclusive a criminalidade ou o uso de drogas, é apresentado pelos meios de comunicação como conseqüência de um destino genético, talvez para que muitos sejam levados a crer que os governos não podem ser responsabilizados pela "falta de sorte" de uma parte de sua população.

Do exposto, pode-se concluir que, no início de 1997, os meios de comunicação denominaram incorretamente de clone à famosa ovelha Dolly, porque ela resultou da união de um ovócito de uma ovelha de cor escura, do qual foi retirado o núcleo (ovócito enucleado), com uma célula da teta de uma ovelha branca. Em outras palavras, a ovelha Dolly herdou da ovelha branca o material genético nuclear, isto é, o DNA contido nos cromossomos do núcleo da célula da teta, e herdou da ovelha escura o material genético citoplasmático, isto é, o DNA contido em organelas denominadas mitocôndrios. Para gerar a ovelha Dolly alcançou-se, assim, o feito espetacular de fazer com que os genes nucleares de uma célula diferenciada originária da teta da ovelha branca passassem a funcionar como os de uma célula indiferenciada, isto é, como aquelas do início do desenvolvimento embrionário.

Visto que para gerar a ovelha Dolly foi essencial a contribuição de uma célula sexual feminina (ovócito), essa ovelha não deveria ter sido chamada de clone. Mas quem pode com os meios de comunicação, que também inventaram a designação estapafúrdia de "bebê de proveta"? Foi, pois, assim, que a técnica empregada para produzir a ovelha Dolly, depois empregada com pequenas variações para outros mamíferos, inclusive, recentemente, para o ser humano, passou a ser conhecida como clonagem e passaram a ser chamados de clones todos animais ou embriões produzidos por essa técnica.

Se eu tivesse que dar um nome para essa técnica eu diria que ela é apenas mais uma dentre as diferentes técnicas de fertilização assistida, que procura unir uma célula sexual feminina enucleada com uma célula somática, isto é, uma célula não-sexual. A meu ver, a única e grande restrição que deve ser feita, no momento, à aplicação dessa técnica à espécie humana reside no fato de que, até agora, os resultados conseguidos com ela em outros mamíferos ainda estão longe de serem considerados bons. De fato, seu rendimento é baixo, isto é, a razão entre os ovócitos necessários e os conceptos resultantes é muito alta, além do que, é alta a proporção dos conceptos gerados por essa técnica que apresentam anomalias congênitas, ou que vão a óbito neonatal por problemas respiratórios e circulatórios ou, ainda, que apresentam peso excessivamente alto associado a aumento do volume placentário.

Entretanto, assim que essa técnica estiver bem padronizada não vejo razões para que, em situações especiais, ela não possa ser aplicada à espécie humana, pois terá uma vantagem sobre a técnica de fertilização assistida que, em casos de esterilidade masculina, emprega doadores de espermatozóides. Visto que esses doadores permanecem no anonimato, sempre existirá o risco de pessoas geradas por um mesmo doador virem a se casar sem saber que são meio-irmãos pondo, assim, sua prole em grande risco de nascimento com anomalias resultantes da consangüinidade próxima. Evidentemente, as pessoas que se candidatarem a esse tipo de reprodução deverão estar sempre conscientes dos riscos de ocorrência de mutações indesejáveis na célula somática usada na união com o ovócito enucleado.

Considero que essa técnica de reprodução assistida, apesar de não estar bem estabelecida, longe está de ser considerada como uma ameaça à humanidade, como ela é apresentada em um número exorbitante de artigos, entrevistas, pesquisa de opinião nos meios de divulgação de todo mundo. De fato, em que consistiria essa ameaça? Evidentemente, se esse tipo de reprodução fosse realizado em grande escala, está claro que a homogeneidade resultante poderia ser prejudicial. Em um clone, quando um indivíduo é suscetível a um microrganismo causador de uma doença, ter-se-á 
que, regra geral, todos os elementos do clone apresentarão a mesma suscetibilidade. Se a doença for letal, todos serão dizimados, com exceção dos que, eventualmente, forem portadores de uma mutação que confira resistência a esse microrganismo.

Esse risco de homogeneidade, entretanto, não existirá, na espécie humana, porque a maioria dos indivíduos de nossa espécie prefere o método clássico e agradável de reprodução, empregado desde os tempos imemoriais, que requer um homem e uma mulher. Portanto, os casos excepcionais dessa reprodução assistida, que tem sidO chamada de clonagem, não poderiam afetar a estrutura genética das populações humanas de modo a ter um efeito significativo.

Impedir o emprego dessa técnica por causa do risco remotíssimo de sua utilização para a criação de uma sociedade homogênea facilmente manipulável não faz o menor sentido, porque já foi demonstrado à saciedade que a manipulação de populações humanas não exige identidade genética. Mais do que a improvável homogeneidade genética, devemos temer o ambiente homogêneo dos regimes totalitários, que conduzem ao fanatismo e ao ódio.

Bernardo Beiguelman é Professor Titular da Faculdade de Ciências Médicas da UNICAMP (Aposentado) e Professor Titular Visitante do Instituto de Ciências Biomédicas da USP

\section{A clonagem sob o olhar da religião}

Em meio as questões éticas, jurídicas e morais que giram em torno da clonagem, há uma que remete à um longínquo embate: aquele que defronta ciência e religião. Certamente os confrontos entre essas duas visões de mundo não são novos, mas encontram uma especificidade ao relacionarse com formas de reprodução artificial e clonagem, pois colocam em cena a possibilidade de dessacralização da vida pela ciência, em oposição à sacralidade afirmada pelas religiões.

Guardadas as devidas diferenças entre três religiões - catolicismo, islamismo e judaísmo - as críticas à clonagem encontram pontos comuns para estas vertentes, como o questionamento das relações de parentesco, que podem abalar o ideal de família, o questionamento da identidade do indivíduo clonado e a possibilidade de aprimoramento genético a partir de um ideal eugênico. Entre as críticas comuns destaca-se a pretensão do homem em comparar-se a Deus.

\section{Clonagem e catolicismo}

Segundo o padre Júlio Monari, ex-assessor de Dom Paulo Evaristo Arns e atual professor de História do Cristianismo e Bioética do Instituto Teológico Pio XIX e do Centro Universitário Assunção, a igreja católica defende a existência de vida humana, desde a fecundação, como algo divino. "A vida humana é um dom de Deus, só Ele é senhor da vida, nesse sentido ela reveste-se de um caráter sagrado. O mandamento bíblico não matarás é indicador desta sacralidade, abrange a vida desde a fecundação até a morte natural. Não é permitido portanto, destruir um embrião para obter células tronco, como tampouco abreviar a vida de um ser humano para extrair órgãos para um transplante, a fim de salvar outra vida", afirma padre Monari. Assim, a clonagem com finalidade terapêutica é rejeitada pelo catolicismo, pois quando se trata de extrair células tronco de um embrião acaba-se infringindo o mandamento "Não matarás". "O embrião já é uma vida, que deve ser respeitada por inteiro", afirma padre Monari.

A Carta Encíclica Evangelium Vitae de João Paulo II, não aborda diretamente a clonagem reprodutiva ou terapêutica. No entanto, condena todas as formas de reprodução artificial. Na Carta, as técnicas científicas de reprodução estão lado a lado com outras ações repudiadas pela igreja, como o aborto, a eutanásia, o suicídio e o homicídio. Padre Júlio Monari afirma que o único meio de reprodução humana admitido pelo catolicismo é originado da relação entre homem e mulher. "A Igreja não permite em hipótese alguma a fecundação in vitro, seja ela homóloga, feita com os gametas do casal, ou heteróloga, com um óvulo ou espermatozóide que não provém do casal", afirma ele.

Ainda de acordo com o padre Monari a clonagem humana "já existe". "É um fenômeno natural e acontece com os chamados gêmeos legítimos. Já a clonagem artificial realizada em laboratório, seja a reprodutiva ou terapêutica, não é admitida pela igreja católica.

A Pontifícia Academia Pro Vita do Vaticano já se pronunciou condenando taxativamente qualquer reprodução via clonagem, tanto para finalidades reprodutivas, quanto para finalidades terapêuticas. Entre os problemas apontados, está a possibilidade da aproximação da clonagem com a eugenia, ciência que estuda as condições mais propícias à reprodução e melhoramento genético 
da espécie humana e que esteve na base de doutrinas como o nazismo. Paralelamente, pontua-se nesses pronunciamentos outros argumentos contrários a clonagem: redução do significado da reprodução humana ao seu aspecto biológico, numa perspectiva que enquadra a lógica da produção industrial; instrumentalização da mulher, a qual passa a estar limitada às suas funções biológicas, a partir do empréstimo dos óvulos e do útero; perversão das relações fundamentais de filiação, parentesco, consangüinidade e progenitura; falta de identidade da pessoa clonada, que passa a ser uma "cópia".

Dos pronunciamentos da Pontifícia Academia Pro Vita, dois abordam respectivamente as clonagens terapêutica e reprodutiva: a "Declaração sobre a produção e o uso científico e terapêuticos das células estaminais embrionárias humanas" , de agosto de 2000, e "Reflexões sobre a clonagem" , de 1997, ambos escritos pelo professor Juan de Dios Vial Correa e Monsenhor Elio Sgreccia. Neste último, é interessante notar que a construção da crítica à clonagem humana se faz numa associação com as idéias do filósofo Friedrich Nietzsche, que se desenvolveram em torno de quatro vetores: a morte de Deus, a Vontade de Poder, o Eterno-Retorno e o Super-Homem e constituem, entre outras coisas, uma das mais profundas críticas ao cristianismo. "A proclamação da morte de Deus, na vã esperança de um super homem, traz consigo um resultado evidente: $a$ morte do homem. De fato, não se pode esquecer que a negação da sua dimensão de criatura, longe de exaltar a liberdade do homem, gera novas formas de escravidão, novas discriminações, novos e profundos sofrimentos. A clonagem corre o risco de ser a trágica paródia da omnipotência de Deus".

\section{Clonagem e islamismo}

O sheik Aly Abdoune, presidente da Assembléia Mundial da Juventude Islâmica da América Latina (WAMY), afirma que o Islã incentiva todo e qualquer avanço científico que venha a beneficiar o homem, mas que a clonagem é totalmente contrária aos princípios islâmicos e à dignidade do indivíduo. Com relação à clonagem humana, sheik Abdoune afirma que a hereditariedade não é respeitada, pois o indivíduo clonado é desprovido de pai e mãe.

Assim como a questão do parentesco, outro ponto em comum com a crítica católica, é o dos conflitos de identidade que podem fazer parte da vida de um indivíduo clonado. "Não se leva em conta as dificuldades que esta criatura terá no futuro, pois é fatal que seja questionada pelos seus pares sobre a forma excêntrica pela qual veio ao mundo. Isto com certeza trará problemas psicológicos e poderá inserir na sociedade pessoas sem o menor senso de família, a base de uma sociedade sadia", afirma o sheik, que ainda questiona a responsabilidade da sociedade para com os frutos das experiências da clonagem, possíveis seres humanos defeituosos, física, moral e mentalmente.

Acerca da clonagem humana, o sheik Abdoune conclui que criar uma máquina para auxiliar na manutenção da vida de uma criatura é algo incentivado pelo Islã, mas imbuir-se da pretensão de dar vida à esta máquina, dotá-la de alma e consciência deve ser totalmente rejeitado por qualquer criatura com um mínimo de senso ético.

O islamismo também condena a clonagem terapêutica. Para o Islã, "o ser humano é merecedor de respeito. Os seres humanos não são criados por partes e não podem ser alvo de experiências. Toda criatura é obra de Deus, o qual instala almas nos corpos, não por pedaços, mas por inteiro. Não se pode aproveitar determinadas partes de um ser vivo e jogar no lixo outras tantas. Isso é assassinato, é desrespeito com o próximo, é uma violação do direito básico à vida", argumenta sheik Abdoune. Neste aspecto, a religião islâmica aceita e incentiva a doação de órgãos, após a morte do indivíduo, desde que haja permissão do doador e da família e que a doação não ocorra por comércio. Segundo o sheik, a doação de órgãos é mais eficiente do que as experiências de laboratório.

\section{Clonagem e judaísmo}

O presidente do rabinato da Congregação Israelita Paulista, rabino Henry Sobel, afirma que é plenamente a favor da pesquisa científica, mas categoricamente contra a clonagem de seres humanos. A posição do rabino muda quando se fala em clonagem animal. Apesar de também conter problemas éticos, ela pode ser justificada com base nos benefícios potenciais para a vida humana. 
A idéia da presunção do homem em tentar se comparar a Deus, também está presente nas críticas e questionamentos feitos pelo rabino. "Sinto enorme apreensão diante desse fenômeno. Quantos embriões e quantos bebês mal formados serão destruídos nesses procedimentos? $\mathrm{E}$ para quê? Para satisfazer o ego de algum cientista? E, mesmo que não houvesse, no processo de clonagem humana, o risco de formação de fetos defeituosos, há um quê de arrogância em reduzir o mistério da Criação a uma experiência de laboratório". A identidade do indivíduo também é apontada como uma forte preocupação para o rabino. "Não posso deixar de me questionar sobre como seria um mundo repleto de clones humanos. Onde ficaria a singularidade de cada indivíduo, a tão fundamental unicidade do ser humano, se essa unicidade fosse negada pela possibilidade de fazer diversos exemplares de uma pessoa", diz o rabino Sobel.

Outro ponto crítico apontado pelo rabino com relação à clonagem é o fato de que, estabelecida a técnica para fins terapêuticos, nada garante que ela não seja usada para fins reprodutivos. Ambas podem ser disseminadas dificultando o controle por parte dos governos e abrindo brechas para a proliferação de clínicas clandestinas, tal como existe para o aborto.

A eugenia também esta entre os pontos que preocupam o rabino. "Não é absurdo imaginar um banco de células fornecendo matéria-prima para clones de pessoas física ou mentalmente superdotadas. A História já nos deu provas aterradoras do que acontece quando se procura 'aprimorar' a raça humana, a mesma História que nos ensina que a ciência não tem consciência". O rabino diz que, assim como existem cientistas e médicos de elevada moralidade, também há aqueles que se entusiasmam com a pesquisa científica, sem levar em consideração a ética, a finalidade e os meios utilizados. Ele tem dúvidas sobre se a humanidade está realmente preparada para assumir a responsabilidade coletiva de discernir o bem do mal.

\section{Clonagem e espiritismo}

Já os espíritas (kardecistas) posicionam-se de uma forma mais cautelosa, apesar de criticarem algumas possibilidades trazidas pela técnica da clonagem. A doutrina espírita surgiu no século XIX e recebeu forte influência do evolucionismo e em muitas ocasiões apoia-se nele e na ciência para explicar questões espirituais. Para a médica espírita Marlene Rossi, presidente da Associação de Médicos Espíritas (Amesp), os últimos avanços na área biológica levaram a uma crise ética sem precedentes na história da ciência e possibilitaram o mais sério encontro entre ciência e religião dos últimos séculos. Para ela, não há dúvidas de que a ovelha Dolly tem alma ou princípio inteligente, do contrário não seria um ser vivo. "Só o Espírito tem o poder de agregar matéria e, consequentemente, de formar o corpo físico, segundo o molde contido em seu envoltório, o perispírito. Assim, se a clonagem humana for sucesso, certamente, não produzirá robôs, mas seres autênticos e distintos uns dos outros, porque cada Espírito carrega em si uma experiência única, de bilhões de anos de evolução", afirma a doutora Marlene Rossi, que ressaltou também a ineficiência atual da técnica de clonagem.

A médica relembra que, para fabricar a Dolly, foram feitas 277 tentativas. Formaram-se 29 embriões e apenas um teve êxito. Constatou-se, porém, que Dolly está precocemente envelhecida. Embora tenha nascido há cinco anos, suas células são equivalentes às de uma ovelha de 12 anos. Este fato estaria ligado a um dos principais problemas da clonagem, o de lidar com células adultas, que estão sujeitas a muitas mutações e, segundo ela, à questão espiritual. O envelhecimento precoce dos clones indicaria que há falhas no processo de produção de fluido vital ou ectoplasma (envoltórios espirituais), provavelmente envolvendo os genes citoplasmáticos e os do núcleo. 0 clone teria herdado um processo vital em andamento, reiniciado do ponto interrompido, quer dizer do número de anos já vividos pela ovelha clonada.

Do ponto de vista espiritual, Marlene Rossi afirma que, no atual estágio evolutivo, a clonagem humana é indefensável. "Nada pode justificar a realização de experiências com organismos humanos vivos; fazer pesquisas in anima nobile é imoral", diz ela. Do mesmo modo, seria indefensável a manipulação de embriões com finalidade eugênica. Com tais "escolhas" genéticas, os cientistas permanecerão circunscritos ao campo físico, sujeitos às mesmas frustrações de Hitler, diante de Jesse Owens, o expoente negro do atletismo norte-americano, vencedor das Olimpíadas de 1938, em que bateu todos os "arianos puros" alemães. Isto ocorre porque não se pode desconsiderar o Espírito imortal, único responsável pelas qualidades físicas, morais e intelectuais da individualidade, argumenta Rossi. 
A médica reconhece que a ciência deve seguir seu curso próprio, desvendando os segredos da natureza. "O nosso respeito pelas conquistas científicas está alicerçado, sobretudo, nas lições de Allan Kardec", diz ela. O respeito aos avanços técnico-científicos não significa uma aceitação tácita de liberdade ética indiscriminada para o cientista. "O pesquisador despreocupado das questões espirituais prosseguirá, normalmente, com a clonagem humana terapêutica; para os especialistas espíritas, no entanto, as indagações éticas continuam em aberto, aguardando respostas mais definitivas", conclui Marlene Rossi.

$(M K)$

\section{Na agricultura clonagem não é novidade}

Na agricultura, a clonagem é uma técnica já bastante utilizada. Segundo Luis Carlos da Silva Ramos, diretor do Centro de Genética, Biologia Molecular e Fitoquímica do Instituto Agronômico de Campinas, as plantas podem ser propagadas de duas maneiras: assexuada e sexuada. "Sexuada é a tradicional, via semente. Você planta uma semente e nasce uma planta. Assexuada, é via clonagem", afirma. Ele explica que tradicionalmente isso é feito por estacas. "Você tem uma planta, corta o caule dela em várias partes e planta. Cada uma dessas novas plantas é uma cópia idêntica à original". A vantagem dessa tecnologia é que se obtém uniformidade. As plantas possuem todas a mesma cor, o mesmo sabor e apresentam o mesmo período de maturação.

Ele ressalta que o ambiente onde será plantada a muda também pode interferir, mas se as plantas tiverem a mesma constituição genética, o controle é maior. Isso é muito importante para culturas de plantas (principalmente com fins comerciais), porque facilita o cultivo e a colheita, e porque daí se obtém produtos de mesma qualidade.

Ramos afirma que o objetivo principal da aplicação da clonagem na agricultura é atingir a uniformidade, mas com a seleção genética é possível conseguir também multiplicar plantas que já foram modificadas, que são mais resistentes a pragas ou doenças, ou que produzem frutos melhores, por exemplo.

Podemos considerar que existem dois tipos de plantas: de polinização cruzada e de autofecundação. As que precisam de macho e fêmea para dar frutos, como o pinheiro do Paraná (o resultado disto é que sempre há plantas híbridas) e as que, se ficarem sozinhas, sem nenhuma intereferência do homem, produzem sementes, como o tomate, o arroz e o feijão.

No caso do tomate, a parte masculina produz grãos de pólem que são expelidos, com pequenos movimentos, e atingem a parte feminina da flor, onde fica o ovário. Então ocorre a fertilização e o fruto cresce. Esse é o processo de fecundação, a própria flor possui a parte feminina e masculina.

Por outro lado, há plantas que têm problemas de incompatibilidade e nesses casos é preciso provocar a fertilização. Como no caso do café Robusta: o pólem não consegue fertilizar as plantas e estas precisam ser cruzadas, perdendo-se a padronização. Em conseqüência disso, faz-se a clonagem dessas plantas, para se obter a uniformidade. Isso não ocorre com o café Arábica.

No caso do café Robusta, escolhem-se duas plantas mais resistentes às condições ambientais e faz-se estacas dessas plantas, que se cruzam e produzem as sementes. Obtém-se, desta forma, maior uniformidade do que se as plantas fossem deixadas para se fecundar naturalmente. "Uma plantação de clones, a não ser que o terreno seja muito acidentado e variável, é muito uniforme", diz Ramos.

A clonagem tem sido usada tradicional e vastamente também na produção de laranja, de uva, de morango, de figo, de goiaba, pêssego, manga, abacate e outras árvores frutíferas.

Desde que virou cultura em larga escala comercial, a laranja é produzida por clonagem. Ramos esclarece que na agricultura, também se usam técnicas de propagação associadas. No caso da laranja, usa-se a enxertia, que consiste na retirada de uma gema (ou broto), implantada no caule de uma planta adulta e com maior resistência às condições do solo, como o limão cravo, por exemplo. A planta que serve de base é chamada de cavalo e a que está sendo enxertada é o cavaleiro ou copa. Assim consegue-se a produção mais rápida e uniforme de frutos. Se produzida via semente, a laranjeira leva aproximadamente seis anos para começar a dar frutos e é mais susceptível a doenças vindas do solo do que o limão. A enxertia é feita com plantas da mesma espécie ou próximas. Com isso garante-se frutos de melhor qualidade. No caso da manga, por exemplo, para produção de frutos de qualidade superior, usa-se como base a espécie coquinho, por exemplo, que é mais resistente. 
Segundo o pesquisador do IAC, existe também a chamada 'clonagem moderna', que surgiu na década de 70, via produção de células. "Nesse caso você retira células de uma planta e transforma em uma nova planta", explica Ramos. Com essa técnica é possível produzir uma quantidade muito grande de plantas, limitada apenas pelo espaço físico do laboratório onde serão desenvolvidos os embriões.

No laboratório, as células são multiplicadas em meios de cultura. Coloca-se um pedaço da folha em um meio de cultura, que forma um calo, a partir do qual forma-se um embrião, que depois é transferido para saquinhos, já com terra. Ali o embrião se transforma em muda para ser plantada já no terreno onde a planta será cultivada. Uma folhinha produz muitos calos e muitos embriões.

Essa técnica é extremamente importante para produzir árvores como eucalipto, pinus ou outras plantas para reflorestamento.

Ramos explica que há também uma técnica que produz o embrião sem passar pela fase de calo, através de modificação na indução de alguns genes. "Induz-se a célula da planta a adotar uma diferenciação. Você tem uma célula da folha, que deixa a ser 'de folha' para ser uma célula embrionária. Esse processo é induzido com hormônios (reagentes), ou reguladores de crescimento, que são sintéticos", explica o pesquisador.

O processo de clonagem em alguns casos, principalmente via micropropagação (a partir de células), tem um custo mais alto e daí decorre resistência de alguns produtores a aderir a essas novas técnicas. Não apenas pelo custo, mas também porque eles ainda não têm a certeza de que obterão melhores resultados. Há também a questão da tradição de plantio e em algumas situações, o aumento da produção não é tão desejável, havendo o risco de o preço do produto ficar tão baixo que inviabilizaria a atividade. Ou seja "a demanda por tecnologia é menor do que os avanços da pesquisa", nota Ramos.

Luis Carlos Ramos conta que a clonagem em plantas é usada também para fazer o que é chamado de 'limpeza viral'. "A maioria das plantas, quando fica no campo, acumula doenças, transmitidas por pulgões e microganismos. Existe um procedimento que consegue restaurar a saúde da planta. Recupera-se uma parte muito pequena desta planta, algo em torno de 0,2 $\mathrm{mm}$ do ápice, que é colocada em vidros com meio de cultura (uma espécie de gelatina que alimenta o ápice) para que ela cresça ali dentro e ela será então uma planta sadia", explica. Dessa matriz saudável, produz-se novas mudas todas sadias, que são levadas ao campo e inicia-se uma nova produção. Obtém-se com isso maior produtividade. Pode-se usar esta técnica na produção de morango, laranja, banana, batata, entre outros.

\section{Clonagem vegetal no Brasil}

Segundo Ramos, o Brasil está bastante adiantado nas pesquisas em clonagem vegetal. Em conhecimento e desenvolvimento, não está atrás dos países desenvolvidos, mas sim em demanda da tecnologia por parte dos agricultores. Na área de reflorestamento, no entanto, devido ao empenho das grandes empresas de celulose instaladas no país em replantar florestas, a tecnologia vem sendo bastante explorada.

Existem empresas de biotecnologia que investem em pesquisas de clonagem de plantas, mas são poucas e com pouco mercado, se comparado ao tamanho potencial do mercado do país. A tendência, no entanto, é que a procura por esse tipo de produto aumente de acordo com a difusão da tecnologia.

\section{Clonagem já tem amplo uso na agropecuária}

A clonagem animal passou a ser mais conhecida em 1997, quando pesquisadores do Instituto Roslin, da Escócia, anunciaram a clonagem do primeiro mamífero, a partir de células mamárias de uma ovelha. O nascimento de Dolly, como foi chamada a ovelhinha, marcou o início de uma corrida pelo aperfeiçoamento da técnica que, se em humanos cria expectativas que ainda não podem ser satisfeitas, e que esbarra em conceitos éticos e religiosos, em animais e plantas tem apresentado resultados positivos a uma velocidade surpreendente.

A clonagem de animais tem aplicação para a conservação e de melhoramento genético. Com fins de conservação ela serve para implantar bancos genéticos que guardem material de diferentes espécies. Para melhoramento, porque é uma técnica que permite reproduzir de maneira mais 
ampla, filhos de animais de qualidade superior, como touros e vacas com maior capacidade reprodutiva ou vacas que produzam mais leite.

Associada à técnica de transgenia, a clonagem animal pode servir ainda para produzir nos animais transgênicos substâncias que auxiliem no tratamento de doenças em humanos. Como exemplo, em 1997, os pesquisadores do laboratório PPL Therapeutics, que financia as pesquisas do Instituo Roslin, produziram por clonagem uma ovelha, a Polly, para produzir a proteína sangüínea alpha-1-antripsina, usada no tratamento da fibrose cística, uma doença genética incurável que afeta uma em cada 1.600 crianças de origem caucasiana. Como matéria-prima, os biólogos usaram uma célula tirada de um embrião de uma ovelha. No núcleo desta, enxertaram um gene humano. A seguir, usaram um óvulo de outra ovelha, descartaram o seu núcleo e o substituíram com o núcleo da célula geneticamente modificada. Criaram assim, uma célula clonada do feto original, que foi introduzida no útero da mãe substituta (de aluguel).

Outras ovelhas, irmãs de Polly, foram programadas para produzir fibrinogeno e proteína ativada C, drogas usadas para impedir a coagulação do sangue.

\section{Clone brasileiro}

No Brasil, o primeiro mamífero clonado foi a bezerra Vitória, da raça simental (leiteira), fruto de experiência conduzida por Rodolfo Rumpf, pesquisador da Empresa Brasileira de Pesquisas Agropecuárias (Embrapa), de Brasília. O anúncio do nascimento da bezerra foi feito em março de 2001, oito meses antes da empresa americana Advanced Cell Technology anunciar o sucesso de seus experimentos com bovinos, que comprovaram um bom desenvolvimento de 24 bezerros clonados. Com isso, o Brasil se tornou o primeiro país fora do grupo dos países ricos a produzir um mamífero clonado.

Segundo Rumpf, para se chegar à Vitória foi preciso, em primeiro lugar, equipar o laboratório. Em seguida, foi necessário desenvolver competências em fecundação in vitro e transferência nuclear para enfim dar início às experiências. Ele conta que as experiências visavam a avaliar a qualidade do citoplasma e do núcleo dos animais, antes de dar início às pesquisas com a técnica de clonagem propriamente dita. "A intenção era verificar a capacidade de produção de embriões e a qualidade do material, além de verificar a capacidade de reprodução das células", afirmou o pesquisador da Embrapa. No caso da Vitória a célula usada para o processo era a de um embrião, mas as pesquisas seguiram também com uso de células somáticas, que têm sido transferidas para animais para avaliações. "Porém, o índice de gestação ainda é muito baixo, em torno de 5\%. Entre 45 e 50 dias é a fase em que se tem as maiores perdas", afirma. Mas Rumpf comemora com a equipe, pois tem conseguido gestações de até mais de 120 dias, sem falar, é claro, do sucesso da bezerra clonada em março deste ano. Rumpf alerta para o fato de que ter fêmeas gestando embriões de 120 dias não significa que os animais cheguem a nascer.

Os experimentos da Embrapa com clonagem tiveram início com o objetivo de implantar um banco genético de bovinos, a partir de células dos animais, ao invés de embriões ou outro material, que poderia ocupar mais espaço nos laboratórios. Para Rumpf, esse banco de células seria muito mais simples.

A partir daí iniciaram-se as pesquisas com a transferência nuclear, técnica que, segundo o pesquisador mostra grande avanço no que tange à embriologia. Ela permite a multiplicação de animais de qualidade superior, o que é de extrema importância para a pecuária. A técnica abre também a possibilidade de gerar clones transgênicos, com fins terapêuticos, e também de se obter animais mais resistentes.

Até o momento, a Embrapa fez experimentos apenas com bovinos, mas segundo Rumpf, no programa de transgênicos, deverão ser incluídos caprinos e ovinos que possuem valor comercial inferior e que apresentam tempo de gestação menor.

Na Faculdade de Medicina Veterinária e Zootecnia da Universidade de São Paulo (USP), em São Paulo, as pesquisas em clonagem animal também vêm sendo feitas com bovinos, mas da raça nelore (produtora de carne), sob a coordenação de José Antônio Visintin.

Visintin afirma que os trabalhos deste ano apresentaram melhores resultados que no ano anterior. Os embriões estão se desenvolvendo bem no laboratório e vários deles já estão sendo transferidos para o útero das mães substitutas. Segundo Visintin, na maioria das vezes a gestação tem um bom início, mas depois ocorrem abortos. "Estamos conseguindo gestações mais longas, por volta de 120 dias, mas ainda não nasceu nenhum bezerro". 
Em fecundação normal, também é comum a perda, tanto de óvulos quanto de embriões, devido a problemas na gestação, doenças e manejo inadequado. Porém essa perda fica em torno de $30 \%$. No processo de clonagem a perda tem sido de $90 \%$, segundo Visintin. Nas experiências desenvolvidas por sua equipe, as principais dificuldades encontradas no processo estão ligadas à fase de reprogramação celular, que é a fase em que deve iniciar a divisão celular. "Essa reprogramação é difícil, talvez precisemos estudar um pouco mais o óvulo. Hoje tem-se verificado que há interferência do citoplasma no processo de clonagem, que também tem DNA", afirma Visintin.

O objetivo das pesquisas da USP é verificar que tipo de embrião será produzido. "Comparamos os embriões desenvolvidos in vitro com aqueles fecundados naturalmente. Avaliamos como esses embriões se desenvolvem. Nós os fixamos, depois contamos o número de células, fazemos a microscopia eletrônica e vários ensaios para comparar com o grupo controle", afirma Visintin.

Em geral, na área de veterinária, a finalidade da clonagem é melhorar os rebanhos, seja para produção de carne ou de leite ou para aumentar a produção de alimentos. O pesquisador da USP lembra que a clonagem em animais, associada à transgenia pode também ajudar em terapias em humanos. Ele dá o seguinte exemplo: "Pela transgenia você consegue um único animal capaz de produzir uma proteína no leite que pode ser usada em um tratamento. Qual a maneira mais lógica de multiplicar esse animal com tal característica? Através da clonagem. É difícil conseguir outro transgênico igual e às vezes este não consegue transmitir para a cria a característica desejada".

Para Visintin, a técnica também se apresenta válida para evitar a extinção de espécies e como um avanço para melhorar a qualidade dos produtos animais. "É claro que tem que ser feita com cuidado, para que não se perca a diversidade genética. Mas no futuro, se o criador tem animais de alta qualidade, poderá fazer o cruzamento entre eles e manter uma diversidade genética. $O$ que não se pode ter é um rebanho único, geneticamente idêntico, com o risco de que haja algum problema e todos os animais serem perdidos", alerta.

Sobre a questão da clonagem terapêutica, o pesquisador da USP acredita que são importantes os estudos com células-tronco, tanto para tratamentos em humanos como em animais. A técnica, associada à transgenia pode auxiliar por exemplo, no tratamento do estresse em suínos, responsável por um grande número de óbitos dos animais, principalmente no transporte dos mesmos. O estresse é causado por um gene. Caso os pesquisadores conseguissem eliminar esse gene do genoma do suíno, logo após poderia se fazer clones desse animal para termos vários indivíduos com maior qualidade. "Os transgênicos são bons pra isso, você pode acrescentar um gene ou tirar um gene que cause um efeito indesejável", acrescenta.

Em relação às outras técnicas que vêm sendo utilizadas na pecuária, como a inseminação artificial e a transferência de embriões, Visintin considera que a clonagem é ainda uma tecnologia muito cara e muito mais difícil, porque ainda se encontra em fase de pesquisa. "Eu acredito que as técnicas serão utilizadas de forma associada. Primeiro utilizando-se a biologia molecular, para fazer um rastreamento daquilo que se deseja. O melhor animal é selecionado, faz-se a multiplicação dele por inseminação e usa-se de novo o marcador molecular, separando e clonando os animais melhores", diz Visintin.

Segundo o pesquisador, quando nascerem os bezerros clonados, esses serão disponibilizados para outros grupos de pesquisa para que estudem se o desenvolvimento desses animais é normal. Quando as pesquisas estiverem mais adiantadas haverá também estudos sobre a própria gestação. "Quando a técnica estiver mais avançada teremos muito material para estudos paralelos", acrescenta Visintin.

\section{Legislação}

Rumpf lembra que as experiências feitas com animais são permitidas pelas normas estabelecidas pela Comissão Técnica Nacional de Biosegurança (CTNBio), mas acredita que deveria haver uma lei que englobasse todas essas questões, como clonagem, terapia regenerativa e de produção de órgãos em animais, de forma a que não haja nenhuma proibição a qualquer pesquisa nessa área.

"Pesquisa não pode ter limite. Quem vai dizer depois se vai usar é a sociedade", afirma Visintin preocupado com possíveis restrições à pesquisa. "Eu faço clonagem e transgenia, mas não 
sou eu que vou produzir clone depois, o importante é que vamos poder dizer: isso presta por causa disso e isso não presta por causa disso".

Para os pesquisadores entrevistados não há nada que justifique a clonagem humana, mesmo porque há outras formas de tratamento, utilizando células multipotentes do próprio organismo e o transplante de órgãos de animais, que supririam a demanda de tratamentos. "Além disso é preciso antes de lançar uma nova tecnologia no mercado, esclarecer a sociedade do que trata a técnica", ressalta Rumpf.

Eles também concordam que a clonagem em animais deve poder ser usada em massa, mas apenas para animais de qualidade superior.

Além da USP e da Embrapa, há grupos de estudos sobre clonagem animal na USP de Pirassununga, e na Universidade Estadual Paulista (Unesp), de Jaboticabal. Estão também se estruturando grupos na Universidade Federal do Rio Grande do Sul, na Universidade Estadual Norte Fluminense e na Universidade Federal do Pará.

\section{Pesquisa no Brasil}

Apesar de o Brasil se encontrar próximo aos países desenvolvidos em relação à técnica de clonagem, os pesquisadores entrevistados apontam dificuldades para realizar os experimentos no país.

Rumpf afirma que a pesquisa teria que ter maior agilidade para acompanhar o que está sendo feito nos outros países: "Aqui paga-se três vezes mais em função das importações e há grande morosidade para se trazer reagentes".

Visintin menciona situações em que perdeu os reagentes por descaso na alfândega brasileira que não manteve o produto sob refrigeração como deveria. "Outra vez tive que solicitar a ajuda do Ministro da Ciência e Tecnologia para que os reagentes fossem liberados rapidamente, nas condições de temperatura adequadas".

A falta de contratação de pessoal de apoio nas universidade e institutos de pesquisa (que exige que pesquisadores assumam atividades administrativas), a falta de produtos e de dinheiro para equipar Para saber mais

adequadamente os laboratórios, dificultam o andamento das pesquisas. Visintin ressalta que os experimentos em seu laboratório vêm recebendo auxílio da Fundação de Amparo à Pesquisa do Estado de São Paulo (Fapesp), que garantiu os recursos necessários para a estruturação do laboratório.

\section{Quem defende a clonagem humana}

Quantos, hoje em dia, defendem a clonagem humana com fins reprodutivos? Provavelmente muitos mais do que os que abertamente se declaram "pró-clonagem". Basta ver, para isso, que o principal argumento da oposição é o de que a técnica ainda não está bem desenvolvida para permitir gerar, com segurança, um clone humano. Sendo assim, no momento em que a pesquisa tiver avançado suficientemente para garantir eficácia ao processo, não mais se justificará a oposição à clonagem reprodutiva, a qual se tornará "apenas mais uma, dentre as diferentes técnicas de fertilização assistida", como diz o geneticista Bernardo Beiguelman (veja artigo nesta edição).

Fiquemos, por enquanto, nos que hoje defendem a clonagem humana com fins reprodutivos (deixemos de lado a clonagem terapêutica, que abertamente já conta com maior apoio da comunidade científica e da sociedade, apesar da polêmica sobre a divulgação da ACT e seu "embrião" de seis células e das discussões sobre o caráter abortivo da técnica).

Há basicamente dois "grupos", ou melhor, duas "ambições" em jogo: a dos que querem demonstrar competência (e atrair atenção) no tratamento da infertilidade/assistência à reprodução e a dos que almejam alcançar a imortalidade, oferecendo "clones de si próprio" a todos os interessados em aderir a uma "nova religião". Ambos repousam inegavelmente sobre "bases científicas", embora seus fins sejam diferentes. Ambos trabalham rodeados de segredo, para "provar no momento certo" o poder de sua técnica. Nenhum deles apresentou, até o momento, resultados concretos. 


\section{Clonagem e reprodução assistida}

No primeiro grupo, encontram-se, notoriamente, o italiano Severino Antinori e o cipriota radicado nos EUA, Panayotis (ou Panos) Zavos. Este é presidente da Human Cloning Foundation (HCF), uma ONG cuja diretoria é formada por indivíduos sem qualquer apoio declarado de uma instituição (universidade ou centro de pesquisa). Basta dar uma olhada na seção "About us" do site:

Panos Zavos (Patron) - info@zdlinc.com (non-direct email address)

Roger Moorgate (Primary administrator) - RogerMoorgate@hotmail.com

Randolfe H. Wicker (Spokesman/Administrator) - Rwicker@gateway.net

HCFadmin (Administrator) - hcloning@aol.com

Christine Ryan (General Editor) - newsletter@reproductivecloning.org (temporary email address)

"ChaosDriven" (Contributor/Admin) - chaosdriven@hushmail.com

Alonzo Fyfe (Contributor/Moderator) - hume@aol.com

Dave Harris (Contributor/Web Designer) - dharris@reproductivecloning.org

Dennis Chute (Contributor) - dennischute@hotmail.com

Margo Lafontaine (Contributor) - SunnyMML@aol.com

A HCF tem seu "braço científico" - a Reproductive Cloning Network, cujo porta-voz é Randolfe H. Wicker, o "primeiro ativista mundial da clonagem humana" (?!). Segundo o site, Wicker fundou o primeiro grupo pró-clonagem humana (The Clone Rights United Front), logo depois do anúncio do nascimento da ovelha Dolly, em fevereiro de 1997. Além disso, a ONG conta também com o apoio estratégico de Shauna, animadora do chat "Clone 4 life", semanalmente mantido na AOL (sábados, às 20h). Embora seja difícil atribuir credibilidade ao que é divulgado pelo site da HCF, há muita informação disponível para quem quiser conhecer os manifestos da organização.

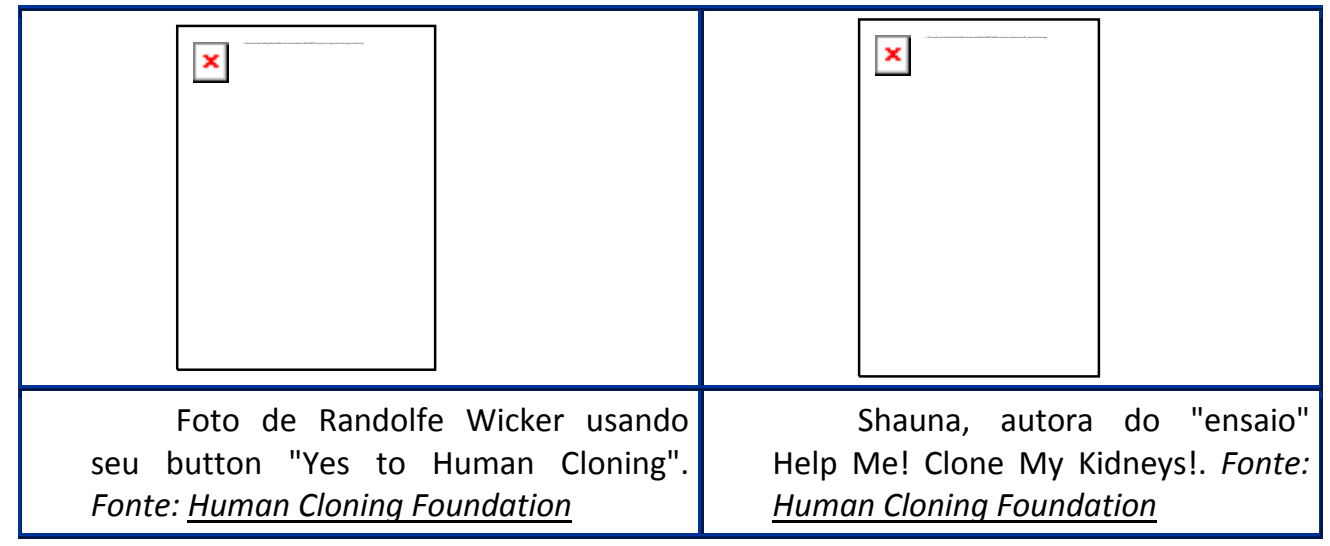

Junto com o biólogo Zavos, o ginecologista, Severino Antinori integra o rol dos famosos. Ele anunciou publicamente, na Academia de Ciências de Washington, em agosto de 2001, que produziria o primeiro bebê clonado ainda neste ano. Dificilmente, no entanto, cumprirá com o anúncio, visto que até agora nada de concreto surgiu. Diz Antinori, em entrevista ao jornal El Mundo (09/08/01), que sua intenção é desmistificar a clonagem. "Clonar não é copiar. Trata-se simplesmente de uma técnica reprodutiva. Eu nunca praticaria a clonagem em uma mulher solteira ou menopausada, que pudesse engravidar com outra técnica reprodutiva", assegura.

$\mathrm{Na}$ bagagem de Antinori, sobressai o "feito" de ter levado uma mulher de 62 a anos a engravidar, do qual o médico tem grande orgulho. Sobre críticas feitas pelo Vaticano, Antinori responde (ainda no El Mundo) que suas conviç̧ões religiosas (ele é católico) não interferem na sua prática. "Que me chamem de Hitler ou Frankenstein, eles têm o direito. Mas eu me compararia mais propriamente a Galileu: sou uma vítima da intolerância", afirma.

Na corrida para chegar ao primeiro clone humano, outro que está no páreo é o biólogo Jan Tesarik, conhecido por ter feito nascer uma criança a partir de células germinativas masculinas cultivadas in vitro. Tesarik já publicou, em maio de 2000, na revista da Sociedade Européia de Reprodução Humana e Embriologia, Human Reproduction, artigo sobre uma técnica que permite 
fundir dois óvulos e poderá ser útil à clonagem humana (veja também a página de Tesarik na revista eletrônica Sito Web Italiano per la Filosofia - SWIF - em italiano).

Outro, ainda, é o físico, também interessado em embriologia, Richard G. Seed. De acordo com a revista Scientific American (nov/2001), ele tem sido um defensor da clonagem, tanto para tratar casos graves de infertilidade, quanto para "substituir um ente amado, já falecido, por um gêmeo". Ele ficou conhecido por ter atraído um competente cientista da reprodução chinês para sua equipe e promete apresentar três grávidas de clones antes de 2002, embora não pareça ter, segundo Sciam, os recursos necessários para isso.

Em tempo. Seed, embora não afiliado, é reconhecido pela Human Cloning Foundation (veja página pessoal).

\section{Clonagem e religião}

\begin{tabular}{|l|}
\hline \\
\\
Livro com a filosofia do \\
movimento raeliano, vendido \\
através do site, inclusive com \\
tradução para o português. \\
Fonte: Site do movimento \\
raeliano. \\
\hline \hline
\end{tabular}

Do outro lado da fronteira,

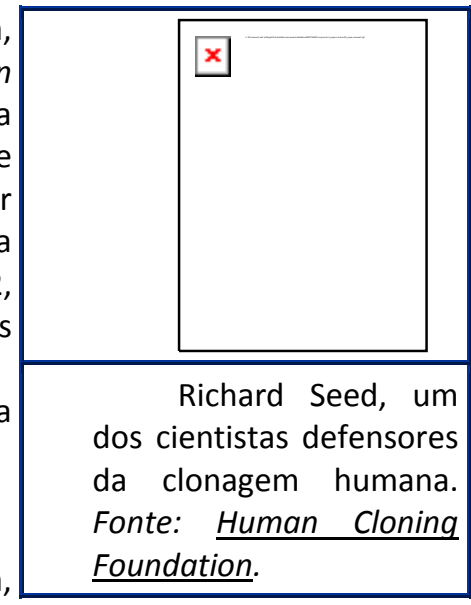
embora não tão longe, estão aqueles que apóiam a clonagem reprodutiva por motivos "religiosos", como é o caso dos raëlianos, que acreditam ter sido a vida na Terra criada por "cientistas" de outro planeta, utilizando DNA. Em seu site (disponível em 18 diferentes línguas!), explica-se que a "revelação" sobre a origem da vida se deu em dezembro de 1973, quando o jornalista francês, Raël, recebeu a visita de um extra-terrestre e este "ser de quatro pés de altura, longos cabelos pretos e olhos amendoados" lhe disse: "Nós somos os criadores de toda a vida na Terra; vocês nos confundiram com deuses; nós estávamos na origem de todas as grandes religiões. Agora que vocês estão maduros o suficiente para entender isto, gostaríamos de entrar em contato oficial através de uma embaixada" (citação do site dos raelianos)

a ciência se reúnem".

Como a clonagem entra nisso? Como o primeiro passo para garantir a vida eterna, considerada uma evolução para o ser humano.

O projeto científico-religioso dos raelianos concretizou-se na empresa Clonaid, dirigida pela química (especialista em metais!) francesa, Brigitte Boisselier. Mas o endereço, bem como as atividades da empresa, são mantidos em segredo, por "razões óbvias de segurança". Na França é que a Clonaid não deve estar, já que a reputação de Boisselier junto a seus colegas cientistas não é lá das melhores.

Ao comentar o anúncio do primeiro embrião humano clonado pela $\mathrm{ACT}$, Boisselier se disse "contente", como reporta o jornal Libération (27/11/01): "Estou maravilhada de ver que não sou a única. Fabricamos embriões clonados todos os dias", afirma a pesquisadora. Como prova, a Clonaid publica em seu site (!) fotos dos embriões clonados, embora não seja possível ver mais do que duas células, não havendo qualquer explicação sobre a imagem.

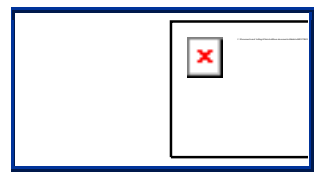




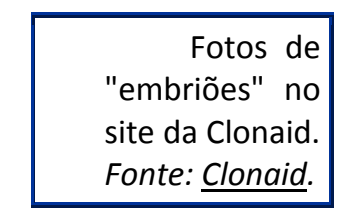

Algumas afirmações dos raelianos, entretanto, chegam a ser risíveis, tal como a do próprio Raël sobre a clonagem direta de indivíduos adultos:

"A clonagem vai permitir à humanidade alcançar a vida eterna. O próximo passo, como fez Elohim com 25 mil anos de vantagem, será o de clonar diretamente um adulto, sem ter que passar pelo processo de crescimento, transferindo sua memória e personalidade a essa pessoa [o clone]. Então, acordaremos depois da morte em um corpo totalmente novo, como depois de uma boa noite de sono". (declaração de Raël no site da Clonaid)

Mas é preciso não nos enganarmos com o caráter desse movimento, pois não se trata de meros lunáticos. Se, por um lado, eles parecem fazer promessas cientificamente infundadas, quiçá impossíveis, por outro lado, estão mexendo com valores bastante caros à grande parte da humanidade, com um argumento bastante persuasivo: "[Em vinte anos] tornar-se-á uma realidade científica o derradeiro sonho humano da vida eterna, que as antigas religiões só prometeram para depois da morte, no paraíso mítico", diz o site da Clonaid.

Que ninguém se engane, tampouco, com o espaço que esses grupos (sobretudo o primeiro) receberão em publicações científicas e na mídia. Como notou Corinne Bensimon, em matéria no Liberátion (18/10/01), a "oposição categórica" de cientistas à clonagem humana reprodutiva cai por terra quando se Ihes coloca a questão crucial: você publicaria um artigo sobre o primeiro clone humano? A repórter fez a pergunta a editores de seis grandes títulos da imprensa médica e científica (Science, Nature, The Lancet, Gynécologie, obstétrique, fertilité, Human Reproduction e Fertility and Sterility). Resultado: ninguém aceitou recusar, por princípio, o possível artigo. "Todos consideram que a clonagem pode, um dia, em certos casos, resolver um problema de esterilidade total. Útil ao indivíduo, logo ético", conclui Bensimon. (MM)

\section{Para saber mais:}

- Theologians oppose human cloning but warn of dangers of a ban

Press release do site Eurekalert!, oriundo do Science and Religion News Service (respeitado pela qualidade de suas informações), com declarações de teólogos e filósofos ligados a instituições de pesquisa, a respeito das restrições éticas e morais à clonagem humana. Em inglês.

- La course aux clones

Dossier do jornal Libération sobre a clonagem. Muito completo, com matérias atualizadas em várias datas sobre o assunto, tratando de vários aspectos (ético, técnico, econômico) da clonagem humana e links para sites interessantes. Em francês. - The first human cloned embryo

Artigo da revista Scientific American anunciando a clonagem da Advanced Cell Technologies. Os autores são os pesquisadores da $A C T$, Jose Cibelli, Robert Lanza e Michael West, e a repórter Carol Ezzell. Em inglês.

\section{Leis restringem pesquisas com células-tronco}

A pesquisa com células-tronco é polêmica. Quando se trata do uso de células-tronco adultas, a legislação costuma ser a mesma dos transplantes de órgãos. A grande discussão gira em torno das 
células-tronco embrionárias obtidas, normalmente, de embriões descartados em clínicas de fertilidade.

Não há um consenso mundial sobre a liberação das pesquisas com células humanas. A Inglaterra foi o primeiro país a liberar, em agosto de 2000, os experimentos com células-tronco de seres humanos. Na Alemanha, a criação de embriões para pesquisa é proibida, embora eles possam ser importados de outros países. No restante da Europa, o assunto ainda é motivo de restrições éticas. Países como Austrália e Israel já se posicionaram a favor das pesquisas.

Em agosto passado, o presidente dos Estados Unidos, George W. Bush, anunciou sua decisão de permitir o financiamento público à pesquisa com células-tronco embrionárias, mas de forma limitada. Serão liberados US\$ 250 milhões para pesquisas em apenas 60 linhas de células-tronco já existentes, que tenham sido criadas com o consentimento dos doadores, a partir de excesso de embriões fecundados apenas para fins reprodutivos. Os cientistas americanos não ficaram muito satisfeitos. Queriam permissão para cultivar células-tronco a partir dos 100 mil embriões que estão congelados em clínicas de fertilidade.

O presidente dos Estados Unidos se opôs, inicialmente, ao financiamento público à pesquisa. Em relação ao financiamento privado não há nenhuma imposição. Pouco tempo depois de assumir, Bush revogou regulamentações propostas pelo governo Clinton. Em abril de 2001, cancelou um painel destinado a analisar projetos de pesquisa. A decisão do financiamento limitado é considerada um meio-termo entre os que dizem que a pesquisa com células- tronco vai garantir avanços na medicina e aqueles que não admitem a destruição de embriões humanos nessa tarefa.

No Brasil, a Lei no 8.974, de 1995, veda a "manipulação genética de células germinais humanas" e trata essa prática como crime, fixando pena de detenção de 3 meses a um ano. A instrução normativa no 8, de 1997, da Comissão Técnica Nacional de Biossegurança (CNTBio), reforça a proibição de experimentos de clonagem. Para fins terapêuticos é permitida a pesquisa com células- tronco, desde que não sejam embrionárias humanas.

A geneticista Lygia da Veiga Pereira, da Universidade de São Paulo (USP), lamenta que no Brasil não se possa pesquisar com células-tronco embrionárias humanas. Desde 1997, ela pesquisa com células embrionárias de camundongo. "Gostaria de poder usar células humanas. Já temos resultados positivos com camundongos, tendo condições de utilizar células humanas manipuladas em laboratório", afirma.

\section{Salvando ou destruindo vidas?}

Desde que o primeiro relato de pesquisa em células-tronco embrionárias humanas foi publicado, em 1998, pela equipe do prof. James. A. Thomson, da Universidade de Wisconsin, nos Estados Unidos, o assunto gerou controvérsias. O ponto central da discussão é o fato de que para retirar as células-tronco embrionárias é necessário destruir os embriões. A Igreja Católica considera a destruição de embriões equivalente ao aborto.

"A utilização, a produção e a destruição de embriões humanos com o simples objetivo de experimentar e obter células matrizes embrionárias constituem um atentado ao respeito absoluto da vida e contra a imensidade do ser humano", escreveu o Papa João Paulo II em mensagem enviada, em novembro de 2000, aos participantes das Semanas Sociais na França. Em um comunicado emitido após o anúncio da clonagem de embrião humano pela empresa norteamericana Advanced Cell Technologies (ACT), o Vaticano disse que a clonagem "nos leva a reafirmar que a vida humana começa, na realidade, já no primeiro instante em que se forma o embrião".

A Lei Judaica (Halachá) não faz objeção ao uso de um embrião em estágio tão primário. De acordo com o presidente da Comissão Bioética do Conselho Rabínico da América, rabino Moshe D. Tendler, um óvulo fertilizado in vitro não tem "humanidade". Sem a implantação em um útero permanece um zigoto ou pré- embrião, não sendo vista a destruição do mesmo como um aborto.

A Igreja Ortodoxa, principal religião da Rússia, condena a clonagem, mesmo para fins terapêuticos. "Nós condenamos a clonagem terapêutica, assim como a reprodutiva, porque o embrião, a partir da concepção, pode ser considerado um portador da dignidade humana e abençoado com o dom da vida", disse o padre Antony Lyin, representante do Patriarcado de Moscou.

Os que defendem a realização de pesquisas com células-tronco embrionárias utilizam o raciocínio moral de que um bem social, que será útil para milhões de pessoas que sofrem de doenças hoje incuráveis, se sobrepõe ao de um indivíduo. Para quem a pesquisa é uma esperança 
de cura no futuro, a defesa é indiscutível. Foi o que mostrou Diogo Mainardi. Em um de seus artigos na revista Veja (edição 1.709 - ano 34 - no 28), o jornalista comentou da seguinte forma o trabalho do cientista Evan Snyder, da Universidade Harvard, que está analisando o efeito de células-tronco implantadas no cérebro de animais que sofreram grave asfixia perinatal (o mesmo que aconteceu com seu filho): "É possível que, um dia, essas pesquisas envolvam células estaminais retiradas de embriões humanos. O que fazer? Deixar as pesquisas de lado? Decretar guerra contra a Igreja Católica?", questionou-se.

\section{Clonagem terapêutica ainda é promessa}

O anúncio feito, no dia 25 de novembro de 2001, pela empresa norte-americana Advanced Cell Technology Inc. (ACT), de que havia concluído a primeira clonagem de um embrião humano, reacendeu a discussão sobre o tema em todo o mundo. Os cientistas produziram um embrião a partir de células da pele de um paciente. Se implantado em uma mulher, o embrião clonado teoricamente poderia dar origem a um ser humano.

O objetivo da clonagem, no entanto, não foi a reprodução, mas sim a obtenção de célulastronco com fins terapêuticos (para serem extraídas do embrião e implantadas no paciente). A vantagem dessa técnica seria a de não oferecer risco de rejeição, pois as células-tronco teriam exatamente as mesmas informações genéticas que o paciente. Mas o transplante não chegou a ser realizado porque o embrião sobreviveu apenas 72 horas.

O que torna a célula-tronco particularmente importante é a sua capacidade de se transformar em diferentes tipos de células. Os cientistas vêem nessa "metamorfose" o potencial tratamento de doenças que afetam milhões de pessoas no mundo. As pesquisas representam uma nova esperança para portadores de doenças neurológicas, diabetes, problemas cardíacos, derrames, lesões da coluna cervical e doenças sangüíneas.

As células-tronco podem ser embrionárias (formadas no interior do embrião nos primeiros cinco dias após a fertilização do óvulo) ou adultas (encontradas em tecidos maduros, tanto no corpo de crianças quanto de adultos). A diferença entre elas está na capacidade de se transformar em outros tipos de células. Enquanto as embrionárias transformam-se em praticamente qualquer célula do corpo (por isso são as mais promissoras para pesquisas), as adultas são mais especializadas e dão origem a tipos específicos de células.

No estágio inicial, as células do embrião ainda não "decidiram" se vão virar célula de sangue, pele, músculo e etc. As células-tronco embrionárias podem ser induzidas a se transformar em células sangüíneas, musculares, hepáticas, de pele, células secretoras de insulina e até em neurônios. Os pesquisadores geralmente obtêm células-tronco embrionárias de embriões descartados em clínicas de fertilidade (embriões que não são implantados num útero e nem destruídos).

Na opinião do professor em Hematologia da Universidade Estadual de Campinas (Unicamp), Fernando Costa, a contribuição da clonagem de embrião humano seria a de fornecer células-tronco para diferentes tipos de transplantes. A geneticista Lygia da Veiga Pereira, da Universidade de São Paulo (USP), considera válida a experiência de clonar um embrião para a retirada de células-tronco. "É uma ótima alternativa para evitar a rejeição no transplante, mas que não se justifica para a reprodução", acrescenta.

O uso de células-tronco substituindo células de áreas danificadas não tem nenhuma relação com a clonagem. O transplante de medula óssea, utilizado no tratamento de algumas formas de câncer, é o exemplo mais comum de transplante de células-tronco. Neste caso, as células-tronco são retiradas da medula óssea ou do sangue periférico do cordão umbilical de doadores ou do próprio paciente. Preferencialmente o doador deve ser compatível com o receptor. A exigência da compatibilidade e o reduzido número de pessoas dispostas a fazer doação fazem com que muitos pacientes fiquem um longo período na fila de espera por um transplante. O Registro Nacional de Doadores Voluntários de medula óssea tem 16 mil pessoas inscritas. Um banco, para ser eficiente, deve ter no mínimo 50 mil doadores.

\section{CÉLULAS-TRONCO}

Potencial das células-tronco adultas 
O processo de rejeição à célula-tronco é o mesmo que ocorre em qualquer transplante. 0 corpo do receptor, a menos que seja tratado com drogas imunossupressoras, rejeitará anova célula. Neste caso, as células-tronco adultas apresentam maior vantagem do que as embrionárias. Elas oferecem a possibilidade de ser retiradas do próprio paciente, evitando o risco de rejeição.

"Do ponto de vista ético é excelente. Não precisar de clone de embrião ou uso de células embrionárias. Só que, por enquanto, não se sabe exatamente quais os fatores que as fazem diferenciar-se", diz a neurocientista Rosália Mendes Otero, da Universidade Federal do Rio de Janeiro (UFRJ), que integra o projeto Instituto do Milênio de Bioengenharia Tecidual, apoiado pelo CNPq. O grande desafio é fazer com que as células-tronco adultas se transformem em células de outros órgãos, como fazem as embrionárias. Essa nova área de pesquisa trata de conseguir separar as células imaturas (com pouco compromisso de diferenciação e por isso mais semelhantes com as embrionárias) das maduras. Em laboratórios, com uso de determinados marcadores poder-se-ia mobilizar as células adultas imaturas e tentar transformá-las em células de diferentes tecidos ou órgãos.

Embora com limitações, as células-tronco adultas também têm plasticidade. Estudos experimentais em animais já comprovaram a possibilidade de transformar uma célula-tronco adulta do sangue em células de outros tecidos, como fígado, músculo e vasos. Na Alemanha, um paciente infartado teve o miocárdio (músculo do coração) recuperado após transplante de células-tronco retiradas de sua medula óssea.

"As células-tronco adultas são uma grande promessa. Imagine um paciente com leucemia em que as células neurológicas estivessem perfeitas. Poderíamos pegar aquela célula neurológica, transplantá-la e ela se transformaria em células sangüíneas", comenta Costa. "Já sabemos que as células-tronco adultas não vão originar células de todos os órgãos. Mas mesmo que sirvam para poucos órgãos já será um grande avanço", acrescenta.

Durante três anos, vários grupos do Instituto do Milênio de Bioengenharia Tecidual estudarão o uso de células-tronco adultas em tecidos do sistema nervoso, ósseo, cardíaco, entre outros. Nos próximos meses terão início os estudos clínicos com pacientes portadores de doenças crônicas do coração. De acordo com a pesquisadora Mendes Otero, a demanda clínica por uma solução a curto prazo é muito grande, principalmente de pacientes com doenças cardíacas e neurológicas.

\section{Células-tronco são estimuladas para transplante}

Todos os indivíduos têm células-tronco circulando pelo corpo. Porém o percentual é baixo e sem capacidade de restaurar um tecido. Para transplante de medula óssea, os médicos podem estimular, com alguns fatores de crescimento, o aumento das células-tronco, utilizando-as para restaurar o tecido hematopoiético (do sangue) ou o sistema imunológico. O primeiro grupo no mundo a apresentar um trabalho sobre o transplante experimental a partir de estimulação de células-tronco foi o da Unicamp. Desde 1994, já foram realizadas mais de 50 cirurgias deste tipo na Universidade.

O professor em Hematologia da Unicamp, Cármino de Souza, explica que as células do doador são estimuladas a aumentarem de quantidade durante cinco dias com o uso de fator de crescimento (G-CSF). Em seguida são transplantadas no receptor. A restituição da célula da medula óssea do paciente acontece entre quatro a cinco dias antes do transplante convencional da medula óssea. Nesse processo, o doador não sofre nenhum efeito colateral. No Japão e na Espanha, existem associações de doadores que acompanham o procedimento.

As células-tronco do próprio paciente que necessita de transplante de medula óssea também podem ser estimuladas a crescer. Nesse caso, o doente passa pela quimioterapia para tratar o tumor maligno e pela estimulação das células-tronco. Este tipo de transplante foi consolidado na década de 90 . Estima-se que $98 \%$ dos transplantes com células-tronco periféricas são feitos dessa forma. A escolha entre a estimulação das células-tronco de doador ou do próprio paciente depende do tipo da doença.

Outra forma de se obter células-tronco para transplante de medula óssea é a retirada do sangue periférico do cordão umbilical do doador. O primeiro problema é o pequeno volume dessas células no sangue. Geralmente ela é benéfica para transplantes em crianças, mas para adultos a quantidade de células-tronco não é suficiente para restaurar a medula óssea ou o sistema imunológico. O procedimento ainda exige a formação de uma equipe específica para entrar em 
contato com a gestante (que deve autorizar a retirada), avaliar suas condições clínicas e colher o material no momento do parto. Depois de colhidas, as células-tronco devem ser manipuladas em laboratório e congeladas em condições especiais (em nitrogênio líquido abaixo de 180), formando um banco para futuras doações.

O Brasil criou um programa para normatizar este tipo de transplante, o Brasil Corde, baseado num programa europeu. De acordo com Souza, existe domínio tecnológico, pessoas treinadas para o acompanhamento, mas ainda não há prática. O programa brasileiro deverá englobar os maiores hemocentros do país com o objetivo de formar um banco com 15 mil amostras de células-tronco retiradas do sangue de cordões umbilicais.

"Hoje é possível você ter acesso às células-tronco para transplantes com relativa facilidade. Essas células já são conhecidas e usadas na prática, mas ainda não foram totalmente exploradas. Temos outros meios de fonte sem precisar de clonagem de embriões. Parece que estão tentando tornar ético algo que é muito polêmico", afirma Souza.

\section{Células-tronco apresentam resultados promissores}

A pesquisa com células-tronco traz promessas para tratamentos de uma ampla variedade de doenças. Dois grupos diferentes de cientistas americanos, um da Universidade Harvard e outro dos Institutos Nacionais de Saúde (NIH, em inglês), por exemplo, testaram com sucesso transplantes de células-tronco em ratos e camundongos com o mal de Parkinson (que havia sido induzido artificialmente).

Implantes das células-tronco poderiam substituir as áreas do cérebro afetadas pelo mal de Parkinson e de Alzheimer, que provocam distúrbios motores e demência devido à degeneração de certas áreas cerebrais. Outro uso seria substituir tecidos cerebrais destruídos em derrames. Os cientistas acreditam que implantes de neurônios embrionários poderiam reverter paralisia e distúrbios de fala provocados por derrames.

Pessoas que sofrem de diabetes melitus (dependente de insulina) têm problemas num tipo especial de células do pâncreas, chamadas de ilhotas. Acredita-se que com células-tronco embrionárias é possível produzir ilhotas, provendo uma cura definitiva para a doença.

O transplante de células-tronco pode ser também uma chance de cura para algumas formas de cegueira. Em doenças tanto da retina como da córnea, células-tronco derivadas de animais adultos ou recém-nascidos indicam excelente habilidade em substituir as células danificadas que possam ser a causa do problema.

Nos laboratórios do Instituto de Pesquisas Schepens Eye, os cientistas utilizam células-tronco de roedores recém-nascidos para tentar substituir os foto-receptores danificados da retina de roedores adultos. As células-tronco adultas transplantadas na retina se tornam células retinais e fazem conexões através do nervo óptico até o cérebro. Embora ainda não se saiba se realmente a função será restaurada, a descoberta é de grande importância.

\section{Células-tronco transformadas em hemácias}

Cientistas da Universidade de Wisconsin (instituição que detém a patente sobre a maioria das linhagens de células-tronco humanas nos Estados Unidos) transformaram células-tronco embrionárias humanas em células sangüíneas. Trabalho semelhante foi feito no Brasil por pesquisadores do Laboratório de Biologia Molecular do Instituto de Biofísica Carlos Chagas Filho, da Universidade Federal do Rio de Janeiro (UFRJ). Só que com células-tronco de embriões de cobaias.

Essas pesquisas são um passo importante para a criação de suprimento de sangue para terapias médicas. Desenvolver células sangüíneas a partir de células-tronco pode, algum dia, ajudar a amenizar a escassez de sangue necessário para transfusões e tratamentos ou fornecer células para transplante de medula .

O processo utilizado pelas pesquisas americana e brasileira foi praticamente o mesmo. As células-tronco foram estimuladas a se diferenciar em células precursoras do sangue através de substâncias conhecidas como fatores de crescimento. Ao serem expostas a essas substâncias, as células-tronco formaram colônias de glóbulos vermelhos (transportadores de oxigênio), glóbulos brancos (de defesa) e plaquetas (responsáveis pela coagulação) idênticas àquelas produzidas na medula óssea adulta. 


\section{Músculo cardíaco recuperado após implante de célula-tronco}

Médicos do hospital da Universidade Heinrich Heine, em Dusseldorf (Alemanha), conseguiram recuperar o músculo cardíaco de um homem de 46 anos que havia tido um infarto. 0 miocárdio foi tratado com células-tronco retiradas da medula do próprio paciente. "O resultado mostra o tremendo potencial das células-tronco adultas", disse o especialista Bodo Eckehard Strauer, chefe da equipe.

Dois meses e meio após receber o implante de células-tronco, o músculo cardíaco do paciente havia se recuperado. O paciente teve um infarto e grande parte das paredes do ventrículo esquerdo de seu coração foi danificada. Quatro dias depois do infarto, foram extraídas células-tronco da medula do paciente, que foram injetadas nas partes danificadas do miocárdio.

Os médicos da equipe acreditam que a recuperação do miocárdio foi resultado do transplante, que favoreceu a regeneração do músculo cardíaco. O processo foi semelhante ao que é feito no transplante de medula com a diferença de que as células-tronco se especializaram em células do músculo cardíaco, regenerando a região afetada pelo infarto.

Na Alemanha, os cientistas não têm permissão para pesquisar células-tronco de embriões coletadas no próprio país, mas nada impede que estudem e pesquisem com células importadas. Por isso, a pesquisa com células-tronco adultas, obtidas da medula, é mais freqüente, já que não é proibida por lei.

Uma pesquisa semelhante à do grupo alemão está sendo desenvolvida no Brasil, pelo Laboratório de Genética do Instituto do Coração (Incor), de São Paulo. Os pesquisadores pretendem retirar células-tronco da medula óssea e implantar no músculo cardíaco do paciente com o objetivo de recuperar a capacidade contrátil do coração, conforme explica José Eduardo Krieger, do Laboratório de Genética.

\section{Pesquisa brasileira em CT já apresenta resultados}

O uso de células-tronco para o reparo de órgãos e tecidos lesados, abre as portas para uma nova era, rica em possibilidades, e batizada de medicina regenerativa, a qual, segundo alguns pesquisadores, apresenta um potencial revolucionário comparável ao do advento da penicilina. Apesar do entusiasmo dos cientistas e das esperanças depositadas por uma parcela considerável da população que poderá um dia beneficiar-se do conhecimento gerado nessa área, são necessárias muitas pesquisas, financiamentos e disposições políticas, éticas e morais para compor o cenário ideal ao pleno desenvolvimento dessa área terapêutica.

"A principal aplicação da terapia de células-tronco seria em doenças crônico- degenerativas, que afetam principalmente pessoas na terceira idade. Com o gradual aumento da expectativa de vida populacional, prevê-se que haja um aumento considerável na ocorrência dessas doenças na população", afirma Ricardo Ribeiro dos Santos, imunologista e coordenador do Instituto do Milênio de Engenharia Biotecidual (IMBT).

A equipe do Centro de Pesquisa Gonçalo Moniz, da Fiocruz, na Bahia, realizou o primeiro transplante de células de medula óssea em pacientes com insuficiência cardíaca devida à doença de Chagas - um feito até então inédito no mundo. O grupo obteve resultados muito rapidamente, em um prazo de três anos e meio, entre a pesquisa básica, iniciada em 2000, e a aplicação clínica, iniciada em junho de 2003. O projeto com células-tronco em pacientes chagásicos contou com o financiamento do Ministério da Ciência e Tecnologia, Fiocruz, CNPq e também do Hospital Santa Izabel da Santa Misericórdia, que chegou a investir recursos próprios para a realização dos transplantes.

Santos explica que o grupo já tem uma base experimental para tratar pacientes em estágios avançados da doença de Chagas, com a utilização de células-tronco medulares. "Esta é uma tecnologia compatível com o Sistema Único de Saúde (SUS), uma vez que o procedimento é muito mais barato do que um transplante cardíaco convencional. Acredito que, com boa vontade política, poderíamos atingir uma população carente, entre dois ou três anos", prevê o pesquisador.

No Instituto do Coração (Incor) de São Paulo, são realizadas, também com bons resultados, aplicações diretas de células-tronco em pacientes com insuficiência cardíaca, causada por doença de Chagas, hipertensão ou de origem desconhecida. Duas técnicas diferentes foram utilizadas: a 
aplicação de células-tronco isoladas da medula e a utilização de um hormônio que estimula a liberação das células-tronco da medula óssea para a circulação sanguínea. "A nossa hipótese de trabalho é a de que as células-tronco podem ser estimuladas para se dirigirem, por si mesmas, para as regiões lesadas do organismo" diz Edimar Bocchi, um dos responsáveis pela pesquisa. Existem, até o momento, 12 pacientes tratados pela técnica. Esta é uma pesquisa em andamento, que apresenta resultados muito estimulantes, segundo o pesquisador. "Se realmente se confirmarem esses resultados, esperamos que esse tipo de tratamento possa auxiliar um grande número de pessoas, principalmente entre os pacientes que precisam de transplantes" informa Bocchi.

Outras linhas de pesquisa com células-tronco também apresentam resultados promissores, entre elas a do tratamento de lesões traumáticas em que se utiliza uma injeção local de célulastronco medulares. Um estudo feito pela equipe do Departamento de Ortopedia e Traumatologia da Faculdade de Medicina da Universidade de São Paulo (USP), conseguiu recriar impulsos elétricos entre a região lesada e o cérebro, pela aplicação de células-tronco medulares. Dentre os 30 pacientes transplantados, todos portadores de lesões medulares crônicas.

As aplicações das células-tronco estendem-se também à engenharia biotecidual, que utiliza o rápido potencial de crescimento apresentado pelas células-tronco para a obtenção de tecidos, tais como ossos, pele e cartilagem, que são cultivados e reimplantados nos pacientes em casos de lesões. Este procedimento já é realizado no Hospital das Clínicas da UFRJ, pela equipe do pesquisador Radovan Borojevic. A equipe trabalha também em estudos envolvendo o tratamento de grandes lesões ósseas, as quais não têm possibilidade de regeneração espontânea. Nesses casos, são utilizadas células-tronco medulares injetadas em matrizes ósseas humanas, que permitem que as células-tronco se diferenciem em células ósseas, promovendo a regeneração do tecido lesado. "Nós acabamos de concluir, em parceria com a Faculdade de Veterinária e Zootecnia da USP, OS estudos com modelos animais e os resultados foram muito animadores. Eu espero que os testes em humanos seja possível ainda em 2004" diz Borojevic.

A equipe da UFRJ desenvolve também trabalhos na linha de tratamento de cardiopatias, em parceria com o Hospital Pró-cardíaco, no Rio de Janeiro. Nesses estudos foram realizados os transplantes de células-tronco medulares em 20 pacientes que aguardavam o transplante cardíaco. Do total de transplantados, 16 pacientes foram estudados por um longo prazo, demonstrando que a terapia celular trouxe consideráveis melhoras clínicas. Todos os procedimentos foram financiados por verbas de pesquisa, porém a expectativa é de que, posteriormente, esta seja incluída na lista das terapias que são cobertas pelo SUS. Borojevic afirma que "nesse caso particular, existe a possibilidade de que o Conselho Nacional de Medicina autorize formalmente esse tipo de terapia, o que vai permitir que ela seja coberta pelos planos de saúde e também pelo SUS".

\section{Doenças auto-imunes}

As células-tronco parecem ser um campo promissor também no tratamento de doenças autoimunes, tais como a artrite reumatóide, o lúpus eritematoso sistêmico e a nefrite lúpica. Algumas experiências já foram realizadas pela equipe de Júlio C. Voltarelli, do Hospital das Clínicas da Faculdade de Medicina de Ribeirão Preto, da USP (HCFMRP-USP). Esses estudos empregam célulastronco medulares do próprio paciente, das quais são separadas as subpopulações não auto-imunes, que são reintroduzidas nos pacientes, depois de passarem por tratamento com quimioterápicos. A quimioterapia destrói as células defeituosas do sistema imune. Voltarelli e sua equipe já realizaram o transplante em 20 pacientes portadores de diferentes doenças auto-imunes, obtendo resultados animadores. Os projetos de pesquisa encontram-se agora na fase que envolve a realização dos transplantes em um número maior de pacientes, em diferentes centros, a fim de comparar os resultados obtidos com a terapia convencional e a que se utiliza das células-tronco. 0 próximo passo, se for comprovada a superioridade do tratamento com células-tronco, será o de torná-lo disponível em hospitais públicos e privados.

Entre as doenças auto-imunes nas quais o tratamento com células-tronco está sendo testado, encontra-se também o diabetes melito. Pesquisadores do Núcleo de Terapia Celular Molecular (Nucel), do Instituto de Química da USP, obtiveram resultados positivos na diminuição dos efeitos do diabetes, através de transplantes de ilhotas pancreáticas. Já os pesquisadores do hospital da USP de Ribeirão Preto, tentam obter resultados semelhantes utilizando uma técnica diferente. A técnica aplicada em Ribeirão Preto envolve a retirada das células-tronco do paciente, que é então submetido à quimioterapia e à ação de imunossupressores, para então reintroduzirem-se as 
células-tronco no próprio paciente, evitando, assim, que as células alteradas do sistema imunológico destruam as células produtoras de insulina do pâncreas.

\section{A pesquisa com células-tronco embrionárias}

Os estudos com células-tronco embrionárias, por enquanto, só são permitidos em modelos animais. Na Fiocruz de Salvador, por exemplo, são desenvolvidas culturas de tecidos, obtidas a partir de camundongos normais e de camundongos geneticamente modificados. Os estudos com célulastronco embrionárias humanas devem demorar, pois trata-se de um tema polêmico, que envolve questões científicas e questionamentos ético, moral e religioso. O país ainda não dispõe de uma legislação específica sobre o assunto, e a lei que ainda está em vigor é a Lei de Biossegurança de 1995, que proíbe as pesquisas com células-tronco embrionárias e também a clonagem de qualquer tipo, terapêutica ou reprodutiva. A nova lei deve ser votada esta semana no congresso, mas esse item dificilmente será modificado. (leia mais sobre a legislação).

"Se fosse aprovada a pesquisa, os resultados não demorariam a aparecer, uma vez que o Centro de Estudos de Genoma Humano, além de outros centros de pesquisa, já possuem um aparato técnico para isso. Os pesquisadores aguardam apenas a autorização para darem início às pesquisas", comenta Andreia Bezerra de Albuquerque, presidente do Movimento em Prol da Vida Movitae, entidade que ajudou na elaboração do documento de pedido de liberdade para a pesquisa científica e que defende também a criação de bancos públicos de sangue de cordão umbilical e placenta.

Vários segmentos da sociedade têm assumido uma posição contrária às pesquisas com células-tronco embrionárias, alegando que o início da vida humana ocorre no momento da concepção, tornando assim a pesquisa com embriões injustificável e anti-ética. Outra argumentação é a de que se estaria abrindo também a possibilidade de que fossem produzidos embriões humanos que serviriam como fonte de células-tronco embrionárias, com possibilidade inclusive de comercialização dos mesmos.

A criação do Instituto do Milênio de Engenharia Biotecidual, tem permitido um avanço nas pesquisas com células-tronco no Brasil, mas há outras fontes de financiamento para esse tipo de pesquisa, tais como a Fapesp, através dos Centros de Pesquisa, Inovação e Difusão (Cepids) - Centro de Terapia Celular, em Ribeirão Preto e o Centro de Estudos do Genoma Humano, em São Paulo -, e a Financiadora de Estudos e Projetos (Finep), vinculada ao MCT. Esta última deverá financiar a construção de uma sede para a pesquisa com células-tronco, em São Paulo, junto ao Hospital Universitário da USP e que abriu um edital de convocação de financiamento de pesquisas aplicadas envolvendo o uso de células-tronco adultas, em janeiro de 2004.

Apesar de todas as controvérsias envolvidas, desde os questionamentos éticos até as dificuldades técnicas, percebe-se que, como no caso das não muito longuínquas discussões a respeito da clonagem de seres humanos, as respostas e soluções serão tomadas, de uma maneira ou de outra, levando-se em conta, não apenas a possibilidade teórica de realização, ou não, de um determinado experimento, mas sim, da real factibilidade, necessidade e aceitação social dos resultados que possam ser decorrentes desse processo.

\section{Em meio à discussão ética, a pesquisa avança em todo o mundo}

Há tempos a comunidade científica internacional discute o potencial para a medicina, os riscos e os aspectos éticos de estudos envolvendo células-tronco. Os que defendem a necessidade de pesquisas com células-tronco embrionárias garantem que elas podem representar grande esperança para o tratamento de doenças como mal de Parkinson e diabetes. Entre os opositores ao uso de embriões em pesquisas, há os que apontam as células-tronco adultas como uma alternativa viável e eticamente razoável para os mesmos fins. Ambas as vertentes já deram resultados promissores, mas ainda há muito a ser feito para que os testes feitos com cobaias de laboratório possam gerar novos tratamentos em humanos.

Entre os mais recentes resultados, uma equipe da Universidade de Toronto, do Canadá, liderada por Duncan Stewart, apresentou no ano passado, na Sessão Científica da American Heart Association, um estudo sobre a restauração da circulação sanguínea em ratos afetados por hipertensão arterial pulmonar, a partir de células-tronco da medula óssea transplantadas para vasos sanguíneos pulmonares. 
Nesse mesmo evento, pesquisadores alemães da Universidade de Dusseldorf apresentaram os primeiros resultados de transplantes de células-tronco retiradas de medula óssea em seres humanos com problemas cardíacos. Essa pesquisa, realizada com 40 pacientes - 20 que se submeteram ao transplante e 20 de um grupo de controle -, indicou que três meses após o tratamento a partir de células-tronco, a fração do sangue bombeado pelo coração dos pacientes passou de $55 \%$ para $65 \%$, e o percentual de tecido cardíaco danificado passou em média de $33 \%$ para $14 \%$.

"O grupo alemão trabalhou com pacientes que tinham infarto agudo. A fração de ejeção [de sangue] dos pacientes alemães, pelo fato de serem pacientes de infarto agudo, é em geral maior que a de pacientes com infarto crônico", comenta o pesquisador Antonio Carlos Campos de Carvalho, do Laboratório de Cardiologia Celular e Molecular da Universidade Federal do Rio de Janeiro (UFRJ). "Mas isto não diminui de maneira nenhuma a importância dos resultados do grupo alemão. Os resultados obtidos na Alemanha mostram que se pode aplicar as terapias ao infarto agudo, e assim, evitar que os pacientes evoluam para um quadro de insuficiência cardíaca muito comum após o infarto", acredita.

Outro estudo que também já deu resultados com um grupo restrito de humanos que se submeteram a transplantes foi realizado pela equipe de Jonathan Lakey, da Universidade de Alberta, no Canadá, com pacientes com diabetes do tipo 1. Essa doença é causada pela redução de disponibilidade ou perda de sensibilidade à insulina, hormônio que regula os níveis de açúcar no sangue e é secretado pelo pâncreas. A partir de células pancreáticas de órgãos doados, os pesquisadores induziram a maturação in vitro de células-tronco de ilhotas, que são as precursoras das células produtoras de insulina. Dos 38 pacientes que se submeteram ao transplante, após um ano, 33 estavam livres da terapia com insulina.

As aplicações das pesquisas com células-tronco, no entanto, ainda são restritas em relação a seres humanos, e além disso os tratamentos já disponíveis são caros e nem sempre dão resultado positivo. Em novembro de 2003, a Associated Press noticiou a morte de um garoto de quatro anos de idade na Califórnia, nos Estados Unidos, uma semana após ele ter recebido o transplante de células-tronco retiradas do cordão umbilical de um recém-nascido. O garoto sofria de síndrome de Sanfilippo, uma doença rara que causa em crianças a perda gradativa da capacidade de falar e andar. Seus pais conseguiram levantar através de doações e do seu seguro de saúde cerca de US\$ 1 milhão para financiar as pesquisas no Duke University Medical Center. Os pesquisadores dessa instituição afirmam que já haviam feito esse mesmo transplante em 11 crianças com síndrome de Sanfilippo nos últimos três anos, e seis delas, segundo eles, passam bem.

Os pesquisadores, em geral, são cautelosos quanto à previsão de quando os avanços na pesquisa vão poder ser aplicados com segurança em tratamentos de humanos. "Apesar dos grandes avanços atuais, o campo de células-tronco ainda está em estágio inicial", comenta Ping Wu, da Universidade do Texas, nos Estados Unidos. "Nós esperamos que o uso de células-tronco venha a se tornar uma das melhores formas de cura de certas doenças, mas eu penso que ninguém sabe ao certo quando isso pode acontecer", opina Jong-Hoon Kim, do National Institute of Neurological Disorders and Stroke, também dos Estados Unidos. "Uma coisa que eu posso supor é que alguns cientistas podem usar essa tecnologia em testes clínicos em um futuro próximo", conclui Kim.

Entre as pesquisas que já haviam dado resultado em anos anteriores, em 2002, Jong-Hoon Kim e sua equipe publicaram o resultado de um estudo no qual geraram uma classe específica de neurônios a partir da cultura in vitro de células-tronco embrionárias. Os neurônios gerados foram usados para reverter sintomas de mal de Parkinson em ratos. Na ocasião, os pesquisadores defenderam que as células-tronco embrionárias seriam capazes de gerar tipos de células especializadas, que por sua vez, seriam terapeuticamente eficazes em animais.

"Células-tronco de embriões humanos, no entanto, são diferentes de células-tronco embrionárias de ratos no que diz respeito à morfologia, métodos de cultura e o seu comportamento", disse Kim à ComCiência por e-mail. "Além do mais, existem algumas diferenças mesmo entre linhas de células embrionárias humanas, dependendo de sua origem", acrescentou. "Apesar desses problemas, há vários cientistas que estão trabalhando com células-tronco embrionárias humanas em todo o mundo e eles estão conseguindo muitos resultados positivos para resolvê-los", afirmou.

Outra equipe do mesmo instituto de pesquisa norte-americano, liderada por Eva Mezey, apresentou em 2003 a hipótese de que alguns tipos de células da medula óssea - que os pesquisadores supõem sejam células-tronco - poderiam entrar no cérebro humano e produzir 
novos neurônios. Essa hipótese foi levantada a partir de um estudo em que os pesquisadores examinaram os tecidos do cérebro retirados na autópsia de quatro pacientes que haviam recebido transplante de medula óssea e sobrevivido por até nove meses. Mezey e seus colaboradores supõem que a irradiação ou algum outro tratamento recebido pelos pacientes pode ter facilitado a entrada das células no cérebro. Os pesquisadores verificaram que nos dois pacientes mais jovens estavam as áreas do cérebro com o maior número de neurônios derivados da medula. Mas eles não conseguiram ainda determinar que fatores de crescimento ou outros sinais induzem as células da medula óssea a entrar no cérebro e produzir neurônios.

Na Universidade do Texas, nos Estados Unidos, a equipe de Ping Wu também já havia apresentado em 2002 resultados de experimentos com células-tronco embrionárias isoladas do sistema nervoso central e transplantadas em ratos adultos, que apontaram a possibilidade de tratamentos futuros para doenças neurodegenerativas. Segundo os pesquisadores, o maior obstáculo, até então, é que a maioria das células-tronco isoladas do sistema nervoso central de adultos ou embriões não se diferenciavam em neurônios quando transplantadas em áreas nãoneurogênicas do sistema nervoso central de um adulto.

O laboratório de $\mathrm{Wu}$ desenvolveu um procedimento in vitro que induz as células-tronco neurais humanas a iniciar sua diferenciação até um certo estágio. "Elas podem transformar-se em tipos específicos de neurônios, de acordo com o local onde são transplantadas", explica Wu. "Por exemplo, elas se tornam neurônios motores quando transplantadas para a medula espinhal", completa. Antes de iniciar os testes com humanos, os pesquisadores ainda estudam se os neurônios gerados são capazes de liberar neurotransmissores e se não há formação de tumor a partir das células-tronco embrionárias implantadas nas cobaias.

Outro estudo com células-tronco embrionárias que gerou resultados promissores em 2002 foi realizado pela equipe liderada por Clare Blackburn, da Universidade de Edimbugo, no Reino Unido. Os pesquisadores implantaram um tipo específico de célula-tronco epitelial em ratos com deficiência na produção de glóbulos brancos, o que resultou na recuperação dos níveis das células de defesa desses animais. Essa pesquisa gerou perspectivas para o desenvolvimento de novos tratamentos para problemas no sistema imunológico e melhora nos resultados de transplantes em pacientes com leucemia. Mas ainda é preciso estabelecer se essa célula específica pode ser encontrada em humanos e ser usada para regenerar a produção de glóbulos brancos.

$\mathrm{Na}$ defesa de estudos como esses, os pesquisadores Stuart H. Orkin e Sean J. Morrison, do Howard Hughes Medical Institute, dos Estados Unidos, em artigo publicado na revista Nature em 2002, observam que as células-tronco coletadas de tecidos de adultos são mais restritas que as embrionárias em seu potencial de desenvolvimento e capacidade de proliferação. Eles apontam como exemplo as células-tronco hematopoiéticas - ligadas à formação e desenvolvimento de células sanguíneas - que formam todo tipo de célula sanguínea in vivo, mas proliferam pouco em cultura in vitro. "Estudos recentes têm levantado a possibilidade de que algumas células-tronco adultas podem restaurar células fora do seu tecido de origem. No entanto, esses resultados são controversos e têm se demonstrado em geral de difícil reprodução", afirmam.

É o que aconteceu, durante um bom tempo, em relação às pesquisas que tentavam diferenciar células do músculo cardíaco em cultura in vitro. Em 1999, Shinji Makino e sua equipe da Universidade de Keio, no Japão, relataram no Journal of Clinical Investigation ter conseguido essa diferenciação a partir de células-tronco hematopoiéticas. Antonio de Carvalho, da UFRJ, explica que a capacidade das células-tronco hematopoiéticas e neurais de gerar diversos tipos de células tecnicamente chamada de pluripotencialidade - permitia supor que essas células, se cultivadas em ambiente adequado, poderiam originar células cardíacas. "Vários laboratórios, inclusive o da UFRJ, tentam desde então, sem sucesso, reproduzir os resultados da equipe de Makino", conta.

"O sistema hematopoiético, porém, não é a única fonte de células-tronco para os transplantes cardíacos", emenda. O laboratório da UFRJ, que iniciou em 2000 um projeto de pesquisa com o objetivo de transplantar células-tronco para corações submetidos a infarto experimental, já conseguiu - ao lado de muitos outros laboratórios no mundo - isolar e cultivar por longo período células de medula óssea de ratos, induzindo-as a se diferenciar em células musculares cardíacas. 0 primeiro relato que descreve a diferenciação de células-tronco da medula óssea em músculos cardíacos, em camundongos infartados, foi publicado na revista Nature em abril de 2001, pela equipe de Donald Orlic, da Faculdade de Medicina de Nova York.

Apesar de ser um campo de pesquisa ainda em estágio inicial, como diz Wu, e não ser possível precisar em quanto tempo trará resultados em tratamentos de humanos, como afirma Kim, as 
pesquisas com células-tronco continuam avançando a cada ano, e cada nova descoberta impulsiona novas investigações em laboratórios de todo o mundo. Independente do avanço da pesquisa, o debate ético continua. E vice-versa.

\section{Faltam leis, sobra polêmica}

A primeira coisa que chama atenção quando buscamos por leis e regulamentações no campo da biotecnologia e genética é justamente a falta de leis e regulamentações específicas. No caso da manipulação de celúlas-tronco, não é diferente. Apesar desse tipo de célula já ser utilizada em pesquisas e terapias na maioria dos países do mundo, uma minoria deles possui uma legislação voltada ao tema.

No Brasil, a situação se repete, ainda não existe uma lei que trate especificamente de pesquisas envolvendo células-tronco. Até pouco tempo, o que impedia a realização de pesquisas com células-tronco retiradas de embriões era uma disposição na Lei de Biossegurança (Lei no 8.974/95) em que havia a proibição a "toda e qualquer pesquisa que implique em manipulação de células germinais humanas, bem como a produção, armazenamento ou manipulação de embriões humanos destinados a servirem como material biológico disponível". A aprovação pela câmara dos deputados no dia 5 de fevereiro, do substitutivo da Lei de Biossegurança (Lei no 2.401) não trouxe alterações significativas nesse aspecto. A nova lei, que ainda precisa ser aprovada pelo senado, continua proibindo a manipulação de embriões humanos, apesar de abrir algumas exceções para "intervenção em material genético humano in vivo" o que poderia possibilitar, dependendo da interpretação da lei, pesquisas com células-tronco embrionárias.

Para Adriana Diaféria, professora de direitos difusos e coletivos da Pontíficia Universidade Católica (PUC) de São Paulo "o que se tem visto é uma diversidade de projetos de lei que tratam desta questão levando em consideração diversos aspectos, muitas vezes conflitantes entre si, o que dificulta, sobremaneira, uma regulamentação adequada sobre o assunto". Na opinião de Diaféria, a regulamentação de novas tecnologias é difícil, principalmente, por causa da incerteza sobre os efeitos causados pela utilização desses novos procedimentos. "Na verdade, a elaboração da legislação ocorre na medida em que demandas concretas no desenvolvimento das atividades nesses novos campos impõem situações de conflito que necessitam de parâmetros claros e seguros", enfatizou Diaféria.

Segundo César Jacoby, representante do Ministério da Saúde na Comissão Técnica Nacional de Biossegurança (CTNBio), a criação de leis relacionadas ao uso de células-tronco embrionárias vem acontecendo de forma lenta, não apenas no Brasil, mas em todo mundo. "Seria impossível acreditar que o processo de construção de uma norma seguiria a mesma velocidade das descobertas científicas. Mesmo porque, o que é tido como verdade hoje, amanhã, pode ser reconsiderado, e aí como ficaria o sistema legal dos países?", argumentou Jacoby.

Além das dificuldades de regulamentação que acompanham os temas ligados à biotecnologia, quando falamos da criação de leis voltadas ao uso de células-tronco é preciso considerar que a procedência dessas células influencia diretamente na questão legal. Assim, ao mesmo tempo que existe uma resolução que autoriza o uso de células-tronco retiradas de sangue de cordão umbilical ou placenta, no caso das células-tronco retiradas de embriões a questão fica mais complexa, girando em torno da legitimidade para permissão das pesquisas já que, nesse caso, implicaria na perda do embrião.

\section{Utilização de células-tronco "adultas"}

Mesmo sem uma legislação específica as pesquisas e terapias com células-tronco "adultas" retiradas do cordão umbilical, placenta e medula óssea - são realizadas no país.

No Brasil existem atualmente oito Bancos de Sangue de Cordão Umbilical e Placentário (BSCUP) (leia reportagem nesta edição). Nesse locais, o sangue contendo células-tronco retiradas do cordão umbilical e placenta de doadores é armazenado para utilização em terapias e pesquisas.

Os BSCUP possuem normas de funcionamento definidas pela Agência Nacional de Vigilância Sanitária (Anvisa). Entre elas estão: a gratuidade da doação; autorização do doador para descarte do material depois do prazo considerado seguro para utilização; vinculação de todo banco de sangue a um serviço de hemoterapia ou de transplante de células progenitoras hematopoéticas; 
possuir um manual técnico operacional com detalhes de todos os procedimentos de seleção de doadoras, coleta, transporte, processamento de células, armazenamento, liberação, descarte e registros.

No dia 18 de janeiro, o prazo estipulado pela Anvisa para que os bancos de sangue se adequassem às suas normas terminou. Mas, segundo a entidade, ainda não houve tempo para estimar quantos já se adequaram.

\section{Pesquisa esbarra no status moral do embrião}

A manutenção de um dispositivo legal que, de forma geral, proíbe o uso de embriões, deixou muitos movimentos favoráveis à legalização decepcionados com o que consideram ser uma barreira para realização de descobertas científicas que podem salvar vidas.

"Faltou compaixão e ética na votação", declarou Andréa Bezerra de Albuquerque, diretora presidente do Movimento em Prol da Vida (Movitae), uma organização que tem com principal bandeira a luta pela legalização do uso terapêutico de células-tronco embrionárias.

No entanto, essa questão ainda não parece estar perto de um consenso moral e legal efetivo. Uma das grandes polêmicas que envolvem o tema, está fora do âmbito da biossegurança, é a definição do status moral do embrião. Ou seja, a necessidade de definir a partir de que momento o embrião passa a ser considerado um ser humano. Essa questão influencia na legalidade acerca das pesquisas com embriões, já que no campo jurídico, tanto a vida, como a dignidade da pessoa humana são considerados bens jurídicos passíveis de proteção.

"Não podemos analisar a questão somente sob a ótica da biossegurança. É preciso observar outros aspectos e princípios constitucionais que protegem a vida humana, em todas as suas formas. Isso sem mencionar a indefinição acerca da natureza jurídica do embrião humano", enfatizou Diaféria. Segundo ela, a regulamentação sobre permissão do uso de células-tronco embrionárias não deveria ser realizada dentro da Lei de Biossegurança. "A Lei de Biossegurança se propõe a tratar de OGM e seus derivados, a regulamentação do uso de embriões para fins terapêuticos dentro desse espaço fica deslocada e contribui para existência de ambigüidades na lei".

Já na opinião da advogada do Movitae, a legalização do uso de células-tronco embrionárias não entraria em contradição com o direito à vida. "Estamos falando de um embrião de até 14 dias, no máximo, são apenas 100 ou 200 células que não estão num útero. Para nós a moralidade está em salvar a vida de milhares de pessoas que morrem por causa de doenças degenerativas"

\section{Indefinição legislativa é internacional}

A complexidade dessa questão pode ser demonstrada através da dificuldade que várias nações enfrentam para definir sua postura e criar leis sobre o tema.

Dos países que integram a União Européia (UE), a Inglaterra foi o primeiro a autorizar a utilização de células-tronco embrionárias em pesquisas, em 2000. Mas, até hoje, apenas Finlândia, Grécia, Suíça e Holanda seguiram seu exemplo.

A maioria dos outros países que integram a UE não possui legislação específica sobre o tema. Em outros, a utilização de células-tronco embrionárias é permitida apenas em casos muito particulares, como o da fertilização in vitro.

Em laboratórios em Cingapura, Taiwam e Coréia do Sul já são realizadas pesquisas com células-tronco embrionárias, mas a legislação sobre o assunto apenas começa a ser discutida. 0 governo da China foi pioneiro ao aprovar, em fevereiro deste ano, as primeiras regulamentações permitindo pesquisa com clonagem de embriões humanos para retirada de células-tronco.

Nos Estados Unidos, a utilização não é totalmente proibida (leia reportagem nesta edição) e uma nova lei federal sobre o assunto está sendo debatida no Congresso. No entanto, os recursos federais para esse tipo de pesquisa são bastante controlados. Apenas dois estados, Califórnia e New Jersey possuem leis permitindo a utilização de células-tronco embrionárias derivadas de reprodução assistida - e que seriam descartadas.

Ao que tudo indica, como afirmou Diaféria, esse assunto ainda terá que ser muito discutido, porque a importância de leis específicas e claras nesse campo é fundamental. Como acrescentou Jacoby, "a criação de normas não tem o poder de resolver todos os problemas, isso é certo, mas a regulamentação pode justamente acabar com posições ambíguas e ser um fator inibidor da má 
utilização dos procedimentos, enquanto não há uma lei que trate do tema, corre-se o risco de uma 'permissão geral'".

\section{Há controvérsia no financiamento nos EUA}

A política norte-americana para o financiamento público de pesquisas com células-tronco embrionárias tem causado desconforto entre os cientistas e alterado a rotina de laboratórios universitários. Em 9 de agosto de 2001, o presidente George Bush decidiu liberar fundos para a pesquisa para pouco mais de 60 linhagens de células-tronco criadas a partir de embriões, proibindo a utilização de recursos federais para novos experimentos desse tipo.

A decisão de Bush surgiu em meio a um debate ético e moral, que se estende até hoje, envolvendo diversos segmentos sociais pró e contra as pesquisas nesse novo campo de estudos. A produção de linhagens de células-tronco envolve a destruição de embriões. Mas, por outro lado, o trabalho com esses tipos de células parece ser uma das esperanças da medicina para o tratamento de doenças como o diabetes, câncer, mal de Parkinson e mal de Alzheimer. Acredita-se que as células-tronco embrionárias têm mais chances de resultar em novos tratamentos, apresentando vantagens em relação às derivadas de células adultas, cuja capacidade de gerar diferentes tipos de tecido celular é limitada.

Atualmente, o Instituto Nacional de Saúde $(\mathrm{NIH}$, na sigla em inglês, uma entidade que reúne os diversos institutos de saúde), órgão que regula a pesquisa com células-tronco nos EUA, já identificou 78 linhagens celulares de embriões que preenchem os requisitos para a pesquisa, mas autorizou somente 12 para o recebimento de investimentos públicos, com uma série de regras para a autorização de pesquisas.

Matéria publicada pelo The Business Journal indica que essa restrição está reduzindo o número de equipes de pesquisadores e prejudicando o avanço científico, podendo causar danos à indústria farmacêutica do país ao limitar sua capacidade de criação de produtos a partir de novas pesquisas feitas, em sua maioria, nas universidades. Segundo a The Scientist um ano após a decisão de Bush, nem todos os pesquisadores estavam conseguindo acesso às linhagens de células-tronco embrionárias para o financiamento público de seus experimentos e os investimentos na área eram poucos, devido às incertezas legais e políticas em torno do assunto.

Como forma de contornar o problema, as universidades norte-americanas estão buscando dinheiro de outras fontes, que não do governo, para manterem todos seus projetos de pesquisa. Assim, preferem montar laboratórios independentes dos já existentes para trabalharem com linhagens de células-tronco não autorizadas, devido às regras impostas pelo $\mathrm{NIH}$, que exige a separação dos gastos com esse tipo de pesquisas daqueles realizados com verbas do Estado. Aparelhos e instalações comprados com dinheiro público, por exemplo, não podem ser utilizados para experimentos com linhagens de células não autorizadas.

Em 2002, o governo norte-americano destinou mais de 387 milhões de dólares para pesquisas com células-tronco, nas 20 instituições de pesquisa integrantes do NIH. Esse orçamento dividiu-se em pesquisas que utilizam células-tronco adultas e embrionárias de linhagens autorizadas, de humanos e de animais. O Instituto Nacional do Câncer [ $\underline{\mathrm{NCl}}$, sigla em inglês] foi o centro com maior gasto em pesquisas com células-tronco adultas, cerca de 70 milhões de dólares. $O$ Instituto Nacional de Diabetes e de Doenças Digestivas e Renais [NIDDK, sigla em inglês] foi o que mais utilizou recursos federais para pesquisas com células derivadas de embriões, com investimentos chegando a quase 4 milhões de dólares.

Segundo Don Ralbovsky, do escritório de comunicações do NIH, não existe um levantamento de dados sobre o investimento privado em pesquisa com células-tronco nos EUA. "Provavelmente algumas companhias estão empenhadas em reunir dados a esse respeito, mas elas não divulgam seu balanço financeiro", diz Ralbovsky.

O orçamento dos NIH para 2004 é de US\$ 27,89 bilhões. Estima-se que mais de $60 \%$ desse valor será gasto em pesquisa básica. Em comparação, no ano de 1997 as indústrias farmacêutica e de biotecnologia gastaram US\$ 27 bilhões em pesquisas biomédicas. Em 1990, somente 14\% do orçamento do setor foi aplicado em pesquisa básica, de acordo com relatório do Conselho Nacional de Pesquisa dos EUA.

No caso das células-tronco, a pesquisa básica depende quase que exclusivamente de financiamento público, já que as indústrias concentram seus investimentos na criação de novas drogas e ferramentas para o diagnóstico, tratamento e prevenção de doenças. 
O governo norte-americano também tem investido em pesquisas com outros tipos de célulastronco. Em 2001, juntamente com o anúncio presidencial da restrição de fundos para as pesquisas com células embrionárias, o governo destinou cerca de US\$ 250 milhões para pesquisas com células-tronco adultas obtidas de cordões umbilicais, placentas e de animais. No início deste ano, o presidente George Bush assinou lei que destina US\$ 10 milhões para a criação do Programa para o Banco Nacional de Células-Tronco de Cordão Umbilical (National Cord Blood Stem Cell Bank Program). A decisão beneficiará diretamente a empresa ThermoGenesis Corp., que desenvolveu a tecnologia para processamento, conservação, estocagem e coleta de células-tronco derivadas de placentas e cordões umbilicais. A quantia inicial será utilizada para a criação de unidades de bancos com esse tipo de células-tronco em todo o país. Estima-se que sejam gastos cerca de US\$150 milhoes para a criação de 150 mil dessas unidades.

\section{0 contra fluxo da pesquisa com células-tronco}

Apesar de muitos cientistas desconsiderarem movimentos contrários a utilização de embriões humanos em pesquisas, a influência desses grupos, religiosos ou não, não é pequena. Sua atuação e opinião contrárias influenciam muitos países católicos, e fazem grande diferença para a formulação de legislações e decisões políticas. Segundo a advogada do Movimento em Prol da Vida (Movitae), Telma Queiroz, que defende a liberdade de pesquisa no Brasil; a força do Vaticano no parlamento italiano é tão grande, que há um certo pessimismo para regulamentar em prol da utilização de embriões humanos em pesquisas. "Eles [os pesquisadores italianos] não conseguem enxergar possibilidades de regulamentação, tamanha é a força do Vaticano no parlamento. Os cientistas estão deixando a Itália e lamentando ser esta uma decisão clerical e política", diz a advogada.

$\mathrm{O}$ argumento contra a utilização de embriões humanos em pesquisa científica, que parte dos católicos, é de que os embriões devem ser considerados como seres humanos, pois a vida começaria no momento da concepção. A opinião, que não é exclusiva de religiosos, encontra repercussão em partidos democrata-cristãos que, na Alemanha, por exemplo, junto com o partido verde formou forte oposição à utilização de verbas públicas da União Européia para a pesquisa com células-tronco embrionárias.

Algumas ONGs também defendem a oposição à pesquisa com embriões baseando-se nesse argumento. Soma-se à ele a afirmação de que é possível realizar pesquisas com células-tronco que não utilizem embriões humanos. Um exemplo desse posicionamento é a HazteOir, uma ONG espanhola, de orientação católica, que procura promover a participação dos cidadãos na vida política acerca de variados temas, dentre eles, o da pesquisa com embriões. Além de estar presente na esfera política, a opinião também encontra respaldo entre cientistas. Um exemplo, também espanhol, é o grupo Hay Alternativas formado por pesquisadores, cientistas, profissionais da saúde, especialistas em bioética e juristas, que condenam "a promoção de uma campanha em prol da utilização de células embrionárias humanas, como estando ligadas a interesses de setores da indústria biotecnológica".

No Brasil, um grupo representante desse posicionamento é o Núcleo Fé e Cultura, da Pontifícia Universidade Católica (PUC) de São Paulo, que publicou recentemente o "Manifesto contra a utilização de embriões humanos em pesquisa", assinado por dois de seus membros, Alice Teixeira Ferreira, também coordenadora do Núcleo Interdisciplinar de Biotética da Unifesp e Dalton Luiz de Paula Ramos, da Universidade de São Paulo e membro correspondente da Pontifícia Academia Pro Vita.

Alice Ferreira explica que o manifesto foi redigido para apresentar a posição institucional do Núcleo, e também para responder a um abaixo-assinado distribuído pelas biólogas Mayana Zatz e Lygia Pereira, na Sociedade Brasileira para o Progresso da Ciência, procurando angariar assinaturas a favor da liberação de experimentos com embriões humanos e da clonagem terapêutica. Segundo Ferreira, o manifesto expressa sua posição contra a clonagem terapêutica e a utilização de embriões humanos em pesquisas - mesmo aqueles que sobram (extra numerários) nas clínicas de reprodução assistida. "Nós achamos que a reprodução assistida em si já é uma complicação. Tanto é que o Sistema Único de Saúde(SUS) não financia a reprodução assistida, e não há dinheiro público no Brasil que financie isso. Os embriões são descartados nessas clínicas porque no Brasil é proibido por lei congelar embrião humano", diz Teixeira.

No manifesto, propõe-se a promoção da proteção desses embriões humanos dos processos de fecundação assistida. "O erro cometido por ocasião da produção e do armazenamento dos 
embriões não justifica, agora, um outro erro: a utilização desses embriões em pesquisas, reduzindoos ao status de coisas ou objetos", afirma-se no manifesto.

Mas não são apenas a idéia de sacralidade da vida ou o estatuto do embrião (se deve ou não ser considerado humano) que permeiam as posições contrárias à pesquisa com embriões humanos. De acordo com Alice Teixeira, existem ainda várias questões legais envolvidas, pois a liberação da clonagem terapêutica poderia abrir caminho na legislação para que seja exigida, por exemplo, uma clonagem humana para resolver um problema de saúde de determinada pessoa. "A questão legal é uma outra razão pela qual fizemos o manifesto, para opor-se a uma tentativa de imposição de uma legislação sobre algo que não deve haver lei. Existem coisas que dependem da consciência de cada indivíduo", afirma Teixeira.

A equipe do Núcleo Fé e Cultura afirma ainda que não existem resultados que comprovem maior eficiência ou melhores resultados de células-tronco embrionárias, em comparação com células-tronco extraídas da medula óssea, por exemplo. "O coordenador do nosso grupo de pesquisa no Instituto de Bioengenharia, Ricardo Ribeiro dos Santos, acaba de ganhar o prêmio Zerbini trabalhando com células-tronco não embrionárias para tratar pessoas portadoras de doença de Chagas", argumenta Teixeira

\section{Biopatentes, eugenia e lucros}

Para Fátima Oliveira, médica e diretora da Rede Nacional Feminista de Saúde e Direitos Reprodutivos, o posicionamento religioso, acerca da sacralidade da vida, deve ser respeitado, mas não é representativo de consensos, já que existem vários manifestos críticos apresentados em congressos e encontros de bioética, baseados em outros fundamentos. Na opinião de Oliveira a polêmica em torno das células-tronco relaciona-se também com um certo aspecto mercadológico, 0 da industrialização da vida, e com a manipulação biológica como passo inicial para essa faceta da bioindústria. "A clonagem terapêutica é também de produtos de células embrionárias na medicina de aprimoramento, uma medicina cuja base doutrinária, a eugenia, é racista. A pesquisa básica e aplicada, assim como as biopatentes e a mercantilização de embriões humanos são negócios rentáveis e com perspectivas de muitos lucros. Tenta-se acalmar os ânimos, falando-se, retoricamente, em clonagem reprodutiva e terapêutica, cujas fronteiras são uma abstração", diz ela.

Além desses questionamentos, a precaução com relação à clonagem reprodutiva e terapêutica, por parte das feministas, deve-se à possibilidade das pesquisas afetarem a saúde das mulheres, sua autonomia sobre o próprio corpo e seus direitos reprodutivos. Sob esse aspecto, Oliveira vê proximidade entre as posições do governo norte-americano e da igreja católica. "Vaticano e Bush são a mesma coisa quando se referem à clonagem e ao direito de decidir das mulheres - ambos aspiram legislar sobre o território dos nossos corpos em todo o mundo", critica Oliveira.

Apesar desse posicionamento de precaução, as feministas concordam com a pesquisa de células-tronco provenientes de adultos, do cordão umbilical e até de embriões, desde que não sejam criados exclusivamente para pesquisa, como exemplifica Oliveira ao citar o Manifesto do Coletivo do Livro de Saúde das Mulheres de Boston sobre a Clonagem Humana, de junho de 2001.

Por outro lado, também aproximam a questão da clonagem com a das novas tecnologias reprodutivas. "A Plataforma Política Feminista (Conferência Nacional de Mulheres Brasileiras), de junho de 2002, afirma em seu capítulo $V$ sobre a liberdade sexual e reprodutiva, sua posição contrária à clonagem reprodutiva. Tal parágrafo é precedido por um outro criticando as Novas Tecnologias Reprodutivas Conceptivas. Participei da elaboração da plataforma e defendi essa resolução. Embora não seja uma apoiadora convicta da clonagem terapêutica, entendo que ambas são faces da mesma moeda e colocam para a humanidade inúmeros desafios, mas sobretudo as perguntas - precisamos disso tudo? E porquê?", argumenta Oliveira.

Apesar de seus questionamentos, Oliveira afirma que a tendência brasileira é de liberação das pesquisas com células-tronco embrionárias em nome da corrida da ciência. "Há uma pressão enorme de parte expressiva da comunidade científica para isso. Além da pressão sobre o governo por parte dos cientistas, existem os grupos organizados em torno de determinadas doenças, que podem se beneficiar de possíveis sucessos das pesquisas", diz a médica.

A diferença de opinião entre Teixeira e Oliveira espelha também diferentes concepções da bioética no debate sobre células-tronco. Para Teixeira, a bioética é um neologismo que apareceu 
em 1971, e o objetivo dela consiste em estudar a moralidade da conduta humana no campo das ciências da vida. "Nós temos que nos preocupar com moral e ética, e não com política. A ética é um comportamento que procura respeitar a pessoa humana, e nesse ponto de vista não cabe a visão política. A religião sim, pode ajudar a bioética, mas não a política. Parto do princípio de Kant, o ser humano não deve ser usado como meio para atingir outro objetivo que não seja sua própria humanidade. Então excluímos qualquer instrumentalização do ser humano para um objetivo que não seja sua própria existência", diz Teixeira.

Já a médica Fátima de Oliveira entende a bioética como movimento social que procura caminhos para a participação qualificada nos debates e nas decisões relativas à biotecnologia. Para ela, a bioética não tem como finalidade solucionar impasses, mas sim levantar questionamentos. "A bioética não é apolítica. Assim como a ética também não é. Ambas sofrem historicamente interferência de classe ou de gênero", diz Oliveira. Segundo a médica, a bioética deve ser entendida como um consenso possível, temporário e mutável entre diferentes moralidades. "Consenso não é unanimidade, nem visão única. No processo de estabelecimento de consensos, mas em especial de um consenso ético, as relações de poder político vêm à tona. As diferentes facções ideológicas presentes na bioética movimento social e na bioética disciplina, fazem política. E mais, buscam hegemonizar a bioética", argumenta ela.

Cada vez mais os embates trazidos pelas novas tecnologias colocam em evidência os limites e a liberdade do fazer ciência, e trazem à tona uma série de rupturas de conceitos e interesses de distintos grupos da sociedade. Estão em jogo interesses políticos, religiosos, científicos e econômicos. A articulação dessa série de interesses, sinaliza mais claramente para o fato de que a ciência não é neutra, nem objetiva, e que as decisões em torno de suas aplicações e rumos certamente não poderão ser puramente científicas.

\section{Brasilcord favorece investimentos para bancos de sangue}

Desde 1998, quando o Brasil, através de centros de pesquisas e hemocentros, passou a dominar a técnica de transplante de medula óssea que utiliza o sangue de cordão umbilical, a Sociedade Brasileira de Medula Óssea tomou a iniciativa de criar um grupo capaz de estruturar uma rede nacional pública de bancos de sangue de cordão umbilical. Em agosto de 2000, uma portaria do Ministério da Saúde regulamentou os primeiros padrões e procedimentos dessa rede, batizada com o nome fantasia Brasilcord.

Nos últimos três anos, membros integrantes da rede reuniram-se várias vezes com representantes da Agência Nacional de Vigilância Sanitária (Anvisa) com o objetivo de definir regras específicas capazes de viabilizar o funcionamento de bancos públicos e privados de sangue de cordão. Em julho de 2003, a Anvisa publicou norma definitiva regulamentando o funcionamento e restringindo a comercialização do sangue de cordão.

O diretor do Centro de Transplante de Medula Óssea (Cemo), do Instituto Nacional do Câncer, no Rio de Janeiro, Dr. Luiz Fernando Bouzas explica que a maior dificuldade encontrada para a montagem dos bancos de sangue é a falta de investimentos. Como a maioria dos bancos de sangue são de instituições públicas é necessário que o governo federal faça os investimentos necessários. Além disso, a criação da rede coincidiu com o período de troca de comando no governo federal. Assim, a gestão passada não chegou a investir grandes somas no projeto e a nova gestão, que levou um certo tempo para entender a necessidade dos investimentos, também não os realizou ainda.

Mesmo assim, o diretor do Cemo acredita que, em 2004, ocorrerão grandes avanços nessa área. Ele ressalta que a relação custo/benefício decorrente da montagem e manutenção dos bancos de sangue é excelente.

Atualmente participam da rede as seguintes instituições: Hemocentro de Ribeirão Preto - SP, Hospital Albert Einstein - SP, Hospital das Clínicas - SP, Instituto Nacional do Câncer - RJ, Universidade Federal do Paraná - Curitiba - PR e Unicamp - Campinas - SP. Todas essas instituições deverão cadastrar as suas unidades no Registro Nacional de Doadores de Medula Óssea (Redome). Os pacientes com indicações para transplante de medula óssea também deverão estar cadastros no Redome. Dessa forma será possível fazer um cruzamento de informações visando identificar o doador compatível. Uma grande vantagem dessa rede é que as células-tronco do cordão estão disponíveis imediatamente.

De acordo com o médico hematologista Gil de Santis, do Hemocentro de Ribeirão Preto, a iniciativa de criação de um banco de sangue de cordão brasileiro se deu pela dificuldade de 
localização de possíveis doadores em bancos internacionais, principalmente no Eurocord, que é o banco de sangue europeu, e também pelo alto custo que isso representa. A importação de uma unidade de sangue de cordão umbilical de bancos internacionais custa US\$ 32 mil. A coleta e armazenamento de cada bolsa de sangue de cordão realizada aqui no Brasil custa ao Sistema Único de Saúde (SUS), aproximadamente US\$ 3 mil.

Gil explica que a miscigenação da população brasileira dificulta muito encontrar um doador europeu que corresponda às suas características. Dessa forma, a criação de um banco de sangue brasileiro aumenta as chances de localização de possíveis doadores, com maior rapidez. Dados do Redome mostram que a chance de localização de um doador brasileiro é vinte vezes maior que a localização de um possível doador nos bancos internacionais.

Além disso, como a proposta é ser uma rede pública, o objetivo é atender o maior número possível de pessoas gratuitamente. Mas isso depende essencialmente de investimentos que, segundo o médico, só podem ser feitos pelas autoridades governamentais.

"O custo de montagem de um laboratório para conservação das bolsas de sangue de cordão é muito alto. Obviamente que com o tempo e o aumento do número de bolsas de sangue, o custo tende a diminuir, mas o investimento inicial é muito alto e só o governo pode bancar", afirma Gil de Santis.

De acordo com informações do Dr. Luiz Bouzas, o INCA possui atualmente um banco de sangue de cordão capaz de armazenar 3 a 4 mil unidades e teve um custo de montagem da ordem de $\mathrm{R} \$ 1,5$ milhão, investimento que ele considera pequeno se comparado com o benefício que trará à população.

A técnica disponibilizada atualmente nesses transplantes está voltada aos pacientes com doenças hematológicas graves como leucemia, anemia falciforme e talassemia. Mas nada impede que, com o avanço nas pesquisas, o sangue de cordão umbilical possa ser utilizado na cura de outros tipos de doenças.

\section{Conservação e riscos de contaminação}

Uma das preocupações do processo é em relação à contaminação e aos possíveis riscos de contaminação. $O$ início se dá na coleta do cordão umbilical, logo após o nascimento. Quando já não há mais contato com a mãe e o bebê, o sangue do cordão umbilical é retirado e armazenado em uma bolsa e depois congelado em tanque de nitrogênio líquido.

Santis afirma que não há perda de qualidade no sangue congelado. "Já foram realizados testes com bolsas de sangue descongeladas mais de dez anos depois de colhidas as amostras e as características do sangue permaneceram inalteradas não representando, portanto, perigo algum para o receptor", explica ele.

Ainda de acordo com o hematologista, existem pesquisadores que consideram possível o congelamento do sangue por período indefinido. Mas isso só o tempo confirmará. O que se sabe, com certeza, é que o sangue pode ficar congelado por um período superior a quinze anos sem sofrer alterações e isso é bastante importante.

Outro fator fundamental na manutenção da qualidade do sangue congelado é o teste de esterilidade microbiológica. Assim que o sangue é retirado do cordão uma pequena amostra vai para teste com o objetivo de confirmação da qualidade do sangue. Caso seja encontrada alguma contaminação no sangue recolhido a bolsa é imediatamente descartada.

\section{Mais informações:}

Anvisa: www.anvisa.gov.br

Revista Ciência e Cultura: Edição: Neurociências - p. 19

\section{Células-tronco desafiam a mídia}

As pesquisas sobre células-tronco não desafiam somente cientistas e religiosos, mas jornalistas também. Para as informações sobre esse tipo de pesquisa chegarem até as pessoas, os jornalistas precisam decifrar o complicado linguajar dos cientistas, driblar os interesses das empresas jornalísticas e farmacêuticas e tentar transpor a falta de consenso ético sobre as pesquisas com células-tronco. 
Neste cenário, como veicular notícias sobre hipóteses, pesquisas e resultados sem grandes distorções? Este é um grande desafio. Por um lado, a mídia desempenha um papel importante na busca da sociedade por uma nova ética e advertindo sobre a necessidade de normas de biossegurança que a protejam no futuro. Por outro, ela deve mostrar as possibilidades abertas pelas novas tecnologias, apresentando para a sociedade, de forma equilibrada, que benefícios concretos a pesquisa pode trazer.

"Embora o veículo primário para a divulgação de informações médicas e a discussão de seus aspectos éticos sejam os journals e publicações especializadas, a mídia leiga também tem um papel a desempenhar. É ela que mais freqüentemente leva a informação à população em geral. E a discussão bioética não pode, evidentemente, ficar restrita aos cientistas. É a sociedade, por meio de suas instituições políticas, que deve definir se a clonagem terapêutica, por exemplo, será aceita" afirma o jornalista e editorialista do jornal Folha de S. Paulo, Hélio Schwartzman. "O cientista precisa, é claro, ser ouvido, mas a palavra final é da sociedade. É ela que sofre as conseqüências (positivas e negativas) de uma nova tecnologia, droga ou procedimento".

Cláudio Cohen, professor de bioética da Faculdade de Medicina da USP e presidente da Comissão de Bioética do Hospital das Clínicas da USP, diz que o papel educativo da imprensa poderia ser melhorado para auxiliar a sociedade a elaborar e aceitar os novos conceitos que a ciência proporciona e que trazem conflitos bioéticos. "Por exemplo, o novo conceito de morte (morte encefálica), o novo conceito de vida (células-tronco, clonagem), ou ainda a quem pertence a vida - ao indivíduo, à sociedade ou a Deus - quando se fala de aborto ou eutanásia. Esses conceitos são de difícil assimilação e ainda não existem valores plenamente normatizados ou universalizados aceitos, eles geram enormes conflitos entre os filósofos, os cientista, os religiosos e a sociedade", afirma Cohen "A imprensa precisa incentivar a discussão dos novos limites da vida que a ciência nos oferece".

Para ele, a mídia tem cumprido com seu papel informativo na área de saúde, mas o papel formativo pode ser melhorado aumentando o número de jornalistas especializados e melhorando a comunicação entre jornalistas e cientistas.

"Na questão das células-tronco a discussão bioética passa pelo conceito do indivíduo sobre o que é vida, isso vale também para o que fazer com os embriões congelados nos casos de inseminação artificial. A mídia tem se posicionado favoravelmente, e eu também, a respeito das pesquisas sobre as células-tronco. Porém, tem-se falado muito pouco sobre esse assunto e a sociedade como um todo ainda não tem uma noção a respeito do que venha a ser célula- tronco e o desenvolvimento desse tipo de terapêutica. Portanto, tem dificuldade de pensar eticamente sobre esse assunto. É mais fácil para um cidadão comum ter opinião própria sobre a guerra ou a pena de morte do que a respeito das conseqüências para a humanidade das pesquisas com células-tronco" afirma Cohen.

Na opinião da jornalista e fundadora do Movimento em Prol da Vida (Movitae), Andréa Bezerra de Albuquerque, a divulgação sobre pesquisas com células-tronco, pela mídia, é falha e sensacionalista. Em parte, ela responsabiliza a imprensa pela confusão que existe entre as clonagens reprodutiva e terapêutica. Segundo ela, o sensacionalismo da mídia deixa os cientistas receosos "Os cientistas contam com a divulgação, querem a veiculação, mas sabem que são muitos os erros que saem na mídia".

Apesar desses problemas, a paixão recíproca entre os cientistas e a mídia é bem conhecida e permeada de interesses. A corrida genética humana, iniciada na década de 1990, com seus megaprojetos executados pelos países ricos, é um bom exemplo da instrumentalização da mídia. Apesar dos resultados do seqüenciamento do genoma humano só terem sido publicados em 2001 pelas revistas Science e Nature, Bill Clinton e Tony Blair apressaram-se, em 2000, para divulgar que os cientistas de seus países conheciam o genoma humano, portanto, detinham o biopoder. Enquanto todos os jornais do mundo enchiam suas páginas com as afirmações de Blair e Clinton, poucos se dispuseram a esclarecer os riscos e benefícios desse novo conhecimento científico, além de não mostrarem os verdadeiros interesses das indústrias farmacêuticas desses mesmos países no desenvolvimento de novas - e, em geral, pouco acessíveis - biotecnologias.

Para Schwartzman, é difícil controlar esse tipo de situação. "O risco de instrumentalização da mídia existe e não está restrito ao campo da medicina. Vale para tudo. Mas a busca pela independência, que já é uma característica de parte da mídia, tende a contrabalançar um pouco esse perigo. Se um dos grandes jornais brasileiros descobrisse que seu repórter recebe 'por fora' dos laboratórios, não tenho dúvida de que esse seria um caso - e justo - de demissão sumária". 
Albuquerque chama a atenção para a manipulação ideológica de informações científicas "Quando são citados os grupos religiosos e toda a polêmica sobre células-tronco, só é ouvida a igreja católica, que é contra. A única contra, diga-se de passagem. A Rede Globo é campeã nisso, nunca fala sobre o assunto, quando fala coloca um padre para dizer que é contra. Os judeus são a favor e nunca são ouvidos, assim como os umbadistas, espíritas, presbisterianos, budistas etc."

Ela se queixa da forma leviana com que os meios de comunicação tratam o assunto clonagem humana, impedindo que as pessoas tenham informações corretas sobre o assunto e saibam diferenciar a clonagem reprodutiva da terapêutica "Um fato clássico de sensacionalismo, que só serviu para atrapalhar nossa luta, foi o destaque para os raelianos (veja reportagem). Tudo isso contribui para um entendimento equivocado sobre o que é a pesquisa com células-tronco e todas suas possibilidades".

Apesar de toda a confusão, é a mídia que pode ajudar a sociedade a enxergar os potenciais e os perigos das pesquisas com células-tronco. Neste contexto, os meios de comunicação não são apenas instrumentos de divulgação de conhecimentos e ideologias sobre as novas biotecnologias, mas um agente de negociação entre os vários atores envolvidos. Resta à sociedade manter-se atenta, para que os economicamente mais fortes não usem os meios de comunição de acordo com seus interesses.

\section{Célula-tronco é promessa para medicina do futuro* Antonio Carlos Campos de Carvalho}

O ano de 2004 está apenas começando, mas o estudo e a utilização de células-tronco continuam sendo uma das grandes polêmicas no campo da bioética. Desde que o fisiologista alemão Theodor Schwann lançou, em 1839, as bases da teoria celular, pesquisadores de todo o mundo sentiram-se instigados com a possibilidade de gerar um organismo adulto completo a partir de apenas uma célula. Pesquisas com células-tronco avançam na busca de tratamentos para muitas doenças que afetam milhões de pessoas, mas o entendimento sobre os detalhes de como um organismo completo, com inúmeros tipos diferentes de células, forma-se a partir de apenas uma célula, já data do início do século 20. Foi nesse período que vários embriologistas, entre eles os alemães Hans Spermann e Jacques Loeb começaram a decifrar os segredos das células-tronco por meio de experimentos com células de embriões.

As pesquisas de Spermann e Loeb mostraram que quando as duas primeiras células de um embrião de anfíbio são separadas, cada uma é capaz de gerar um girino normal, e que, mesmo após as quatro primeiras divisões celulares de um embrião de anfíbio, o núcleo dessas células embrionárias ainda pode transmitir todas as informações necessárias à formação de girinos completos. Em 1996, o nascimento da ovelha Dolly, primeiro mamífero clonado a partir do núcleo de uma célula adulta diferenciada, trouxe a resposta sobre a possibilidade de um núcleo de uma célula totalmente diferenciada ser capaz de gerar um indivíduo adulto normal. Foi a primeira demonstração de que a vida animal poderia surgir de outra forma, a partir do núcleo de uma única célula do corpo de um indivíduo adulto.

Todo organismo pluricelular é composto por diferentes tipos de células. Todos os 200 tipos celulares distintos encontrados entre as cerca de 75 trilhões de células existentes em um homem adulto, derivam das células precursoras denominadas células-tronco, também denominadas células-mãe. São células mestras que têm a capacidade de se transformar em outros tipos de células, incluindo as do cérebro, coração, ossos, músculos e pele. O processo de geração das células especializadas - do sangue, dos ossos, dos músculos, do sistema nervoso e dos outros órgãos e tecidos humanos - é controlado pelo genes específicos na célula-tronco, mas os pesquisadores ainda não dominam todos os fatores envolvidos no processo. Compreender e controlar esse processo é um dos grandes desafios da ciência na atualidade.

É fundamental que as pesquisas com células-tronco embrionárias e adultas continuem a ser feitas para que possamos ter respostas para perguntas como: qual o melhor tipo de célula-tronco para ser usada em cada doença degenerativa? qual a melhor via de introdução dessas células? por quanto tempo duram os efeitos benéficos das terapias com células-tronco? será necessário e possível repetir-se os procedimentos de injeção de células-tronco no mesmo paciente? Ter uma legislação permitindo o uso de células-tronco embrionárias humanas em pesquisa é de fundamental importância. 
Pesquisas recentes mostraram que células-tronco apresentam duas características básicas: são indiferenciadas e têm a capacidade de gerar não só novas células-tronco como também grande variedade de células de diferentes funções. Para realizar esta dupla tarefa (replicação e diferenciação), a célula-tronco pode seguir dois modelos básicos de divisão: o determinístico, no qual sua divisão gera sempre uma nova célula-tronco e uma diferenciada, ou aleatório (ou estocástico), no qual algumas células-tronco geram somente novas células-tronco e outras geram apenas células diferenciadas.

Existem diferentes tipos de células-tronco, mas a diferença básica está na existência de células-tronco embrionárias e células precursoras do organismo já desenvolvido, chamadas célulastronco adultas. Estas últimas recebem também a denominação pós-natal por alguns cientistas, por estarem presentes em recém-nascidos e no cordão umbilical.

\section{Células-tronco embrionárias}

Em 1998 a equipe do biólogo James Thomson, na Universidade de Wisconsin (instituição que detém a maioria das patentes sobre linhagens de células-tronco humanas nos Estados Unidos) tornou o sonho biotecnológico um pouco mais real, quando conseguiu isolar as primeiras células-tronco de embriões humanos. No mesmo ano, também foram isoladas células embrionárias germinativas humanas, derivadas das células reprodutivas primordiais de fetos, pelo embriologista John Geahart, da Universidade Johns Hopkins (EUA). Como as ES, as EG também são pluripotentes, ou seja, podem gerar qualquer célula do organismo adulto. A disponibilidade de células ES e EG humanas abriu horizontes impensáveis para a medicina, mas também trouxe complexos problemas ético-religiosos.

As células-tronco embrionárias têm a capacidade de se transformar em praticamente qualquer célula do corpo, com exceção da placenta, e são encontradas somente nos embriões. É essa capacidade que permite que um embrião se transforme em um organismo pluricelular formado. Cerca de cinco dias após a fertilização, o embrião humano se torna um blastocisto - uma esfera com aproximadamente 100 células. As encontradas em sua camada externa vão formar a placenta e outros órgãos necessários ao desenvolvimento fetal do útero. Já as existentes em seu interior, células-tronco embrionárias, formam quase todos os tecidos do corpo. Apesar de estudadas desde o século 19, há apenas 20 anos pesquisadores conseguiram cultivar em laboratório células retiradas da massa celular interna de blastocistos de camundongos. Essas células conhecidas como ES podem se proliferar indefinidamente in vitro sem se diferenciar, mas também podem se diferenciar se forem modificadas as condições de cultivo. A grande conquista dos cientistas foi encontrar as condições adequadas para que as células ES proliferem e continuem indiferenciadas.

Outra característica especial dessas células é que, quando reintroduzidas em embriões de camundongo, dão origem a células de todos os tecidos de um animal adulto, mesmo as germinativas (óvulos e espermatozóides). Apenas uma célula ES, no entanto, não é capaz de gerar um embrião. Isso significa que tais células não são totipotentes, como o óvulo fertilizado. O fato das células ES reintroduzidas em embriões de camundongo gerarem tipos celulares integrantes de todos os tecidos do animal adulto revela que elas têm potencial para se diferenciar também in vitro em qualquer desses tipos, de uma célula da pele a um neurônio. Vários laboratórios já conseguiram a diferencição de células ES de camundongos, em cultura, em tipos tão distintos quanto as células hematopoiéticas (precursoras das células sangüíneas) e as do sistema nervoso (neurônios, por exemplo), entre outras. A capacidade de direcionar esse processo de diferenciação permitiria que, a partir de células-tronco embrionárias, fossem cultivados controladamente os mais diferentes tipos celulares, abrindo a possibilidade de construir tecidos e órgãos in vitro, na placa de cultura, tornando viável a chamada bioengenharia.

O potencial terapêutico das células-tronco não pode e nem deve ser desprezado. $O$ não benefício da utilização das células-tronco sempre existe, mas é preciso distingui-lo do malefício. Este sim seria um problema. Os testes clínicos realizados no mundo até o momento tiveram como objetivo principal afastar a possibilidade de malefícios. Até por este motivo não se realizaram ainda testes clínicos com as células-tronco embrionárias, pois ainda não há segurança de que se injetadas em pacientes no seu estado indiferenciado elas não possam levar ao surgimento de tumores.

\section{Células-tronco adultas}

Em 1998, a equipe italiana liderada pela bióloga Giuliana Ferrari, do Instituto San Rafaelle- 
Tellethon, apresentou o primeiro relatório sobre as propriedades das células-tronco adultas. Os pesquisadores estabeleceram que células-tronco de medula óssea podem dar origem a células musculares esqueléticas e podem migrar da medula para regiões lesadas no músculo. Estudos recentes constataram que além da pele, do intestino e da medula óssea, outros tecidos e órgãos humanos - fígado, pâncreas, músculos esqueléticos (associados ao sistema locomotor), tecido adiposo e sistema nervoso - têm um estoque de células-tronco e uma capacidade limitada de regeneração após lesões.

Mais recente ainda é a idéia de que essas células-tronco adultas são não apenas multipotentes (capazes de gerar os tipos celulares que compõem o tecido ou órgão específico onde estão situadas), mas também pluripotentes (podem gerar células de outros órgãos e tecidos). A pluripontecialidade foi demonstrada pela equipe de cientistas liderados pelos neurobiólogos Christopher Bjornson, da Universidade de Washington, Seattle, USA e Angelo Vescovi, do Instituto Nacional Neurológico de Milão, Itália, em janeiro de 1999. Os pesquisadores demonstraram que uma célula-tronco adulta derivada de um tecido altamente diferenciado e com limitada capacidade de proliferação pode seguir um programa de diferenciação totalmente diverso se colocada em um ambiente adequado. Também deixou claro que o potencial de diferenciação das células-tronco adultas não é limitado por sua origem embriológica: células neurais têm origem no ectoderma e células sangüíneas vêm do mesoderma embrionário. Essa pluripotencialidade das células-tronco adultas elimina não só as questões ético-religiosas, envolvidas no emprego das células-tronco embrionárias, mas também os problemas de rejeição imunológica, já que células-tronco do próprio paciente adulto podem ser usadas para regenerar seus tecidos ou órgãos lesados. Infelizmente, a pluripotencialidade das células-tronco adultas tem sido contestada por estudos desenvolvidos em diversos laboratórios, tornando ainda mais necessário que os cientistas possam investigar o uso de células-tronco embrionárias humanas nas terapias celulares, comparando-as com as células-tronco adultas.

Gostaria de enfatizar que as células-tronco autólogas (do próprio indivíduo) de qualquer fonte não curam as doenças, pois não corrigem as causas da doença seja ela infecciosa, ambiental ou genética. Elas permitem que se regenere os orgãos afetados, mas se a causa da doença não for removida, o orgão será novamente lesado. Sendo assim, é importante que se possa conjugar as terapias celulares com a gênica, por exemplo, na cura de doenças de origem genética. Isto requer a manipulação genética das células-tronco do indivíduo para corrigir o defeito genético antes de injetá-las no paciente. Se a doença for de causa infecciosa ou ambiental é preciso que além da terapia celular se remova o agente infeccioso ou ambiental causador da doença.

Existe a possibilidade da utilização de células-tronco heterólogas (de indivíduos diferentes do receptor) mas ainda há muita discussão a respeito de problemas de rejeição imunológica com estas células. Aqui novamente há ainda necessidade de muita pesquisa.

Antonio Carlos Campos de Carvalho é professor de fisiologia e biofísica da Universidade Federal do Rio de Janeiro e um dos responsáveis pelo Instituto de Bioengenharia Tecidual do Instituto do Milênio.

* Adaptação por Margareth Franco, do artigo de Antonio Carlos Campos de Carvalho, publicado originalmente na revista Ciência Hoje (SBPC), vol. 29, n. 172, junho de 2001, com autorização, revisão e atualização do autor.

\section{Clonagem terapêutica... e polêmica}

Lygia Pereira

Em 1997 foi anunciado o primeiro mamífero gerado a partir de células somáticas de um indivíduo adulto através da transferência nuclear, a ovelha Dolly. Em sua trilha foram gerados clones de camundongos, bovinos, e porcos, entre outros. Porém, desde 1997 aprendeu-se muito pouco sobre os mecanismos de reprogramação celular que fazem um núcleo já diferenciado, quando introduzido em um óvulo enucleado, reiniciar o programa de desenvolvimento embrionário e dar origem a um ser completo, um clone. Uma coisa aprendemos: que a clonagem como forma de reprodução de mamíferos é extremamente ineficiente. Em geral, as taxas de sucesso até 2002 variam entre $0.4-3 \%$ dependendo da espécie e do tipo celular utilizado (ver tabela abaixo). 


\begin{tabular}{|c|c|c|c|c|}
\hline $\begin{array}{l}\text { Célul } \\
\text { a doadora }\end{array}$ & Espéci & $\begin{array}{l}\text { Oó } \\
\text { citos } \\
\text { reconstr. }\end{array}$ & $\begin{array}{l}\text { Nasci } \\
\text { mentos } \\
\text { vivos }\end{array}$ & bs. \\
\hline \multicolumn{5}{|l|}{ Fetal } \\
\hline \multirow[t]{6}{*}{$\begin{array}{l}\text { Fibro } \\
\text { blasto }\end{array}$} & $\begin{array}{l}\text { Camun } \\
\text { dongo }\end{array}$ & 30 & $(0.2 \%)^{5}$ & \\
\hline & Bovino & 27 & $\begin{array}{r}4 \\
(1.4 \%)\end{array}$ & $\dagger$ \\
\hline & & 18 & $(0.3 \%)^{6}$ & \\
\hline & Cabra & 28 & $(1.1 \%)^{3}$ & \\
\hline & Porco & 21 & $(0.5 \%)^{1}$ & \\
\hline & Ovelha & 41 & $(3.4 \%)^{14}$ & $1+$ \\
\hline \multicolumn{5}{|c|}{ Adulta } \\
\hline $\begin{array}{l}\text { Gld. } \\
\text { Mamária }\end{array}$ & Ovelha & 22 & $(0.4 \%)^{1}$ & \\
\hline ulosa & $\begin{array}{l}\text { Camun } \\
\text { dongo }\end{array}$ & 68 & $(1.3 \%)^{31}$ & \\
\hline \multirow[t]{2}{*}{$\begin{array}{l}\text { Fibro } \\
\text { blasto }\end{array}$} & Bovino & 44 & $(1.4 \%)^{6}$ & $\dagger$ \\
\hline & & $\begin{array}{l}66 \\
4\end{array}$ & $\begin{array}{r}8 \\
(1.2 \%)^{8}\end{array}$ & \\
\hline
\end{tabular}

Tabela 1: Taxas de sucesso da clonagem reprodutiva de mamíferos (adaptado de Yanagimachi R. Cloning: experience from the mouse and other animals. Mol. Cel. Endrocrin.187:241-8, 2002). $\left(^{\dagger}\right)$ Animais mortos após o nascimento.

No entanto, Dolly foi um marco na história da ciência, demonstrando pela primeira vez que uma célula já diferenciada era capaz de acessar toda a informação contida em seu genoma e dar origem a todos os tipos celulares encontrados em um indivíduo adulto. Esses mesmos mecanismos podem ser utilizados para a geração de tecidos específicos desse indivíduo, um processo chamado de clonagem terapêutica (Figura 1). Na clonagem terapêutica, o embrião clonado, gerado pela transferência nuclear (um conglomerado de aproximadamente 100 células), é dissociado no laboratório para a obtenção das chamadas células-tronco (CTs) embrionárias, células pluripotentes, que dariam origem a todos os tipos de células do embrião. Essas células podem ser multiplicadas em cultura, mantendo essa capacidade de diferenciação quase ilimitada. Alterando suas condições de cultivo, pode-se induzir a diferenciação dessas células em tecidos específicos, como músculo, neurônios, hepatócitos e até óvulos e espermatozóides. Assim, as CTs embrionárias podem ser fonte de tecidos para transplantes. Nos últimos 15 anos, experimentos com CTs embrionárias de camundongo vêm demonstrando o potencial terapêutico dessas células diferenciadas in vitro. A utilização de um embrião clonado como fonte de CTs embrionárias permitiria a geração de tecidos geneticamente idênticos ao paciente, logo, imunologicamente compatíveis, eliminando-se o risco de rejeição do transplante. 


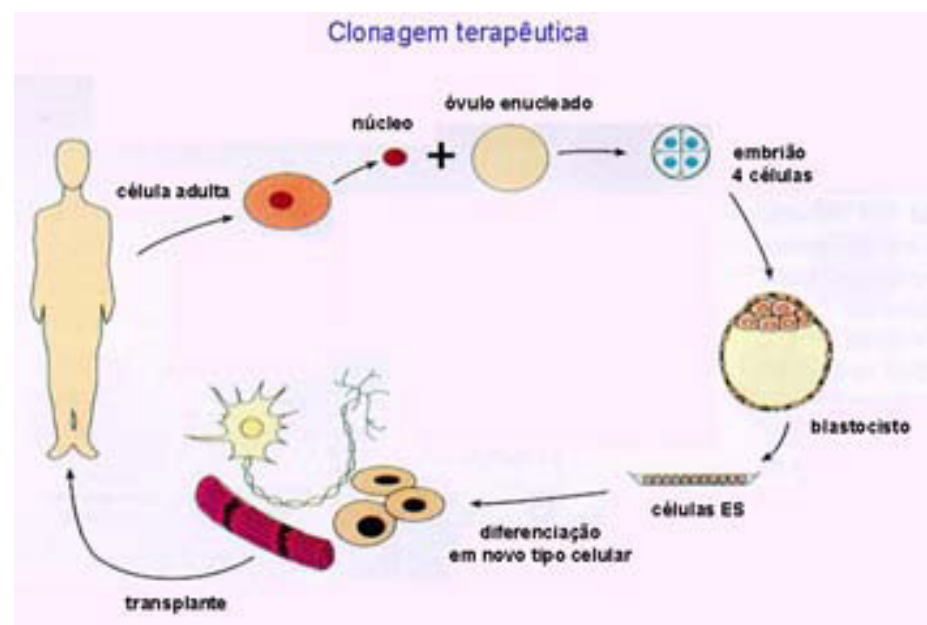

Figura 1: Clonagem terapêutica. A partir de uma célula somática do paciente, é gerado um embrião clonado que, dissociado, dará origem a CTs embrionárias geneticamente idênticas ao paciente.

Essas CTs embrionárias podem ser diferenciadas em tecidos específicos de acordo com a doença do paciente. (reproduzido de "Clonagem, fatos e mitos", Editora Moderna, 2002)

A capacidade de CTs embrionárias de se diferenciar em qualquer tipo de tecido representa um enorme potencial de aplicação médica. De acordo com dados do Centers for Disease Control and Prevention, nos Estados Unidos, aproximadamente 3 mil norte-americanos morrem todo ano de doenças que no futuro poderão ser tratadas com tecidos derivados de CTs embrionárias. Um passo importante nessa direção foi o estabelecimento de linhagens de CTs embrionárias humanas. Experimentos realizados com CTs embrionárias murinas poderão ser repetidos e adaptados para as linhagens humanas.

A geração de CTs embrionárias imuno-compatíveis através da transferência nuclear e seu uso terapêutico in vivo (a clonagem terapêutica) já foram demonstrados em modelos animais. Resta agora decidirmos se essa metodologia será utilizada em seres humanos. A obtenção de CTs embrionárias envolve obrigatoriamente a destruição do embrião (blastocisto - um embrião préimplantação de 5 dias - basicamente um conglomerado amorfo de 100 a 200 células), o que em certas culturas/religiões é inaceitável (Figura 2). Por isso, a clonagem terapêutica tem sido tema de grande polêmica em diversos países, inclusive na Organização das Nações Unidas (ONU).

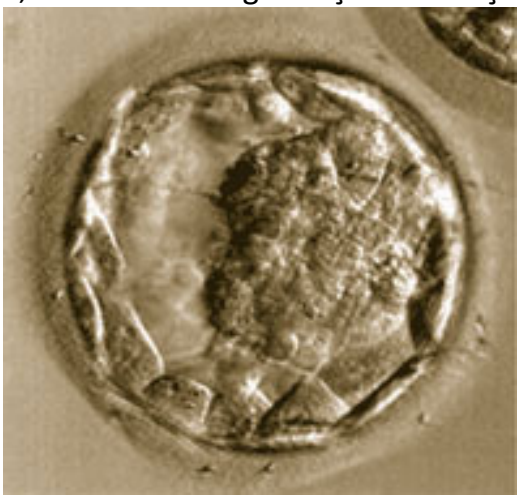

Figura 2: Blastocisto. Embrião humano de 5 dias que deve ser destruído para a obtenção de CTs embrionárias.

Em dezembro de 2001, a ONU decidiu elaborar uma Convenção Internacional Contra a Clonagem Reprodutiva de Seres Humanos, deixando claro que a clonagem como forma de reprodução de seres humanos é internacionalmente repudiada e uma ameaça à dignidade do ser humano da mesma forma que a tortura, a descriminação racial, o terrorismo etc. Durante as reuniões para a elaboração desse tratado internacional, com a participação de mais de 80 países, ficou clara a existência de um único consenso internacional: a clonagem não deve ser utilizada como forma de reprodução assistida em seres humanos.

Já a aplicação da ciência da clonagem na geração de embriões clonados para fins terapêuticos - a clonagem terapêutica - foi alvo de grande polêmica. Enquanto os EUA defendem os direitos do embrião a qualquer custo - apesar de todo dia destruírem legalmente centenas de embriões 
excedentes em suas clínicas de fertilização in vitro - países como Israel, China e Inglaterra permitem seu uso para fins terapêuticos. A posição norte-americana, apoiada pela Santa Sé, Itália e Espanha, é de que o processo de clonagem, e não o produto final - o clone humano -, deve ser internacionalmente banido. Mesmo que isso impeça o desenvolvimento de uma área promissora da medicina regenerativa. Essa é uma discussão complexa que envolve aspectos legais, éticos, culturais e religiosos, e que terá que ser decidida individualmente por cada país. O conflito de posições em relação à clonagem terapêutica foi tal, que até o final de 2003 impediu a elaboração da Convenção Internacional contra a clonagem reprodutiva.

Além dos dilemas ético envolvidos na destruição do embrião para a obtenção das CTs embrionárias, aqueles contra seu uso argumentam que, se permitida a geração de embriões clonados para pesquisa, isso abrirá uma brecha para a clonagem reprodutiva e surgirá um comércio de embriões/óvulos. Toda nova tecnologia está sujeita ao mau uso. Esse risco não justifica a interrupção do desenvolvimento daquela tecnologia. O que precisamos é de legislação e mecanismos de vigilância que nos protejam dos riscos do uso degenerado dos embriões/óvulos para pesquisa, sem impedir o avanço da mesma.

Finalmente, um argumento "científico" utilizado pelos antagonistas ao uso das CTs embrionárias para terapia de reposição de tecidos é que não há necessidade das mesmas uma vez que temos as CTs adultas, encontradas principalmente na medula óssea e no sangue do cordão umbilical e placentário, entre outros tecidos. Sem dúvida, as CTs adultas são uma fonte promissora e não-polêmica de tecidos autólogos para transplante. No entanto, ainda não podemos garantir que essas possuam o mesmo potencial de diferenciação que as CTs embrionárias. Assim, o momento é o de abrir o leque das pesquisas, investir em todos os tipos de CTs para determinarmos o potencial terapêutico de cada uma delas. Além disso, o que aprendermos com as pesquisas com as CTs embrionárias nos permitirá manipular as CTs adultas de forma a explorar toda a sua capacidade de trans-diferenciação.

Nos Estados Unidos o uso de embriões humanos, mesmo aqueles descartados nas clínicas de reprodução assistida, em pesquisas financiadas pelo governo é proibido. Essa posição é repudiada pela comunidade científica que, em 1999, se manifestou formalmente através de uma carta assinada por 67 cientistas premiados com o Nobel publicada na revista Science.

Por outro lado, como são permitidas pesquisas com CTs embrionárias estabelecidas antes da proibição ou através de financiamento privado ou estabelecidas em outros países, o National Institutes of Health (NIH) criou várias linhas de financiamento voltadas para o desenvolvimento das pesquisas com CTs embrionárias 58. Essas linhas incluem projetos voltados à diferenciação dessas células em diferentes tecidos; à compreensão dos mecanismos moleculares de totipotência e diferenciação das CTs embrionárias; à formação de pessoal qualificado (cursos de treinamento em cultivo de CTs embrionárias; bolsas para estágios em laboratórios que trabalham com CTs embrionárias); ao estabelecimento de bancos de linhagens de CTs embrionárias disponíveis a grupos de pesquisa, entre outros. Esse investimento reflete a importância dos estudos com CTs embrionárias, tanto aplicados quanto básicos.

No Brasil, a nova Lei de Biosegurança, aprovada pela Câmara dos Deputados no início de fevereiro de 2004, proíbe "a produção de embriões humanos destinados a servir como material biológico disponível". Por outro lado, permite a "clonagem terapêutica com células pluripotentes", o que é uma grande contradição já que a clonagem terapêutica, como já vimos, necessariamente envolve "a produção de embriões humanos destinados a servir como material biológico disponível".

Confusões conceituais à parte, é uma lástima que o país ceda às pressões de grupos religiosos e proíba de forma radical a pesquisa com embriões humanos. Concordo que este seja um material biológico precioso, mas a proibição total representa um atraso para o desenvolvimento da ciência no país. Poderíamos criar mecanismos de vigilância e legislações que permitissem esse tipo de pesquisa por grupos qualificados, credenciados de acordo com sua capacidade demonstrada na área - isso foi feito com muito sucesso em relação ao acesso a materiais radioativos, por exemplo. 0 Brasil perde uma grande oportunidade de ter uma vantagem competitiva na promissora área de pesquisa com CTs embrionárias. A permissão controlada nos tornaria líderes nesse tipo de pesquisa na América Latina, atraindo pesquisadores de outros países que nos ajudariam na formação de novos pesquisadores nessa área. Depois de tantos anos de investimento em pesquisa, temos os cérebros, temos a infra-estrutura - agora nos falta a lei.

Lygia Pereira é bióloga e professora do Instituto de Biociências, da Universidade de São Paulo 


\section{A propósito da utilização de células-tronco Marco Segre}

A discussão ética quanto à utilização de células-tronco de pré-embriões produzidos mediante reprodução assistida, seja pela fertilização "in vitro", ou com as técnicas emergentes de clonagem (clonagem terapêutica), passa inevitavelmente pela delimitação do instante no qual quisermos atribuir a um conjunto de células o respeito devido à vida. A retirada de células-tronco produz a morte desse "conjunto de células": daí, fulcro das polêmicas é quanto a podermos produzir esses pré-embriões com o fim específico, não de gerarmos novos seres humanos, mas sim de fabricarmos "remédios" contra patologias graves, como a doença de Alzheimer, o síndrome de Parkinson, leucemias, etc. É sabida a capacidade das céculas-tronco desencadearem a formação de tecidos variados, sendo inestimável o valor dessa capacidade para se reporem, no "vivo" (caso dos doentes portadores das moléstias já referidas) tecidos e órgãos vitalmente prejudicados. A polêmica passa também pela preocupação de que a utilização dessas novas técnicas possa levar, progressivamente, a uma "desumanização", com dano irreparável ao respeito à vida, vigente em nossa cultura.

São esses aspectos que passaremos a discutir, na busca de contribuir para seu deslinde, e normatização da prática biomédica.

A sempre renovada discussão referente ao momento no qual o embrião humano passa a "merecer" respeito à sua vida e integridade, apenas comprova a aleatoriedade e o caráter pragmático da caracterização do início da vida.

Esta observação encontra esteio, por semelhança, na recente mudança do conceito de morte, quando a morte encefálica, por motivação essencialmente utilitária, foi identificada com morte.

Assim como o desenvolvimento das técnicas de transplantes de órgãos vitais, a partir de doadores "mortos", passou a exigir a pré-definição do momento de morte, para que esses fossem viáveis, o desenvolvimento das técnicas de reprodução assistida está estimulando um questionamento do momento de início da vida, para que, pelo destino que não se sabe qual dar aos embriões excedentes, este outro avanço científico (a reprodução assistida) não seja obstaculizado.

Com relação a esse aspecto, é fácil perceber o quanto a caracterização do momento de início da vida no instante da fecundação do óvulo, mormente nos países em que o aborto é crime (conceitua-se aborto, ainda, pelo menos no Brasil, como toda interrupção do processo gestacional), dificulte e mesmo impeça o desenvolvimento de novas técnicas de reprodução assistida. As técnicas de reprodução assistida (R.A.), intervindo na junção dos gametas masculino e feminino, produzindose um embrião (ou pré-embrião, como muitos preferem denominar, nessa fase), requerem a replicagem desses "conceptos" para que haja expectativa de êxito com sua implantação no útero: há, portanto, praticamente sempre, embriões excedentes, que habitualmente são congelados, mas cuja utilização para se dar prosseguimento ao processo concepcional é muito improvável. Assim, como aliás também ocorre nas situações em que clinicamente se indica a redução embrionária (proteção da vida da mulher gestante, que não pode suportar mais do que um número definido de fetos), há que se encontrar uma forma, que a lei avalize, de se poderem descartar embriões. E, para que isso possa ocorrer será necessário que se modifique o conceito de momento de início da vida, uma vez que, na maioria dos países, o direito à vida é cláusula pétrea das Constituições (exceção seja feita, conforme já se referiu, aos países em que, embora se reconheça como momento de início da vida a fecundação, permite-se a prática do aborto).

É portanto indispensável que se altere o conceito de momento de início da vida, visando aos referidos objetivos absolutamente pragmáticos, ou que se abram exceções legais que permitam a inutilização de embriões - ou, de sua utilização para outros fins, e é este, especificamente, o assunto de que iremos tratar, neste artigo - ou, então, finalmente, que se proíbam todas essas novas técnicas, que, ao menos em princípio, visam à busca de melhor qualidade de vida para pessoas que desejam procriar! Absolutamente inaceitável é, entretanto, o caráter retrógrado de conceituações e leis existentes, a menos que se deseje, como ocorre no conto "O aprendiz de feiticeiro" - no caso específico da reprodução assistida - que o homem, tendo o poder de replicar embriões ao seu talante, não os possa destruir, quando eles não fossem ser aproveitados, tornando-se portanto vítima de seu "feitiço".

Afinal, a vida é um continuum, que, mesmo abstraindo-nos das crenças atinentes à espiritualidade, poder-se-ia considerar tendo seu início material nos pré-gametas e seu fim na esqueletização do cadáver. Milhares de trabalhos já se escreveram sobre a partir de quando e até quando se reconheça que um ser humano é pessoa (e este, certamente, não será um deles), mas é 
absolutamente evidente o caráter inerente a uma cultura, aleatório e pragmático da tentativa de se estabelecer esses limites.

\section{Clones humanos, para que?}

Tratando-se de um horizonte novo, que se descortina, são dificilmente previsíveis as virtuais aplicações dessa técnica. Quando, de acordo com a lenda grega, Prometeu produziu o fogo, ele certamente não tinha a perspectiva da sua extraordinária descoberta, nodal para a história da humanidade.

Serão os clones humanos produzidos tão somente para a replicação genética de pessoas, atendendo ao desejo (compreensível) de sujeitos isolados ou de casais estéreis? Acho que não.

Tentativa do homem, de alcançar a imortalidade? Considero essa expectativa vã, uma vez que a identidade genética não é determinante da personalidade (como, muito bem se vê nos gêmeos univitelinos), e, muito mais, a repetição genética nada tem que ver com a continuação da subjetividade.

E a construção de órgão, visando à realização de transplantes, não será também ela uma perspectiva terapêutica capaz de produzir um extraordinário salto no aumento da qualidade e quantidade de vida do ser humano? Poder-se-á objetar que a "produção" de seres humanos, ainda que para fins terapêuticos, é uma violência contra um dos inestimáveis valores de nossa cultura: a vida. Mas, a esta altura, remetemo-nos às considerações anteriores sobre vida. E estendemos essa reflexão para, havendo vida, a partir de que momento consideramos a existência de um sujeito, a quem atribuiremos direitos? Sempre tentando construir nosso futuro, desestigmatizando sentimentos morais incrustados em nossa cultura, não poderemos pensar na construção de clones sem estruturas nervosas, e que, por semelhança, compararemos a corpos em estado de morte encefálica, e que certamente não consideraremos pessoas e sim "bancos de órgãos"?

Cabe reiterar que não serão as técnicas que nos levarão a um "inferno ético".

Parece-nos não devermos temê-las, aprioristicamente, e sim monitorar cuidadosamente a sua aplicação.

Face às premissas supra, está clara nossa posição francamente favorável à utilização de células-tronco, a partir de pré-embriões produzidos in vitro, sejam eles resultantes de fecundação ou de clonagem. A importância desse avanço científico e tecnológico tem, ao que tudo indica, enorme valor terapêutico. A possibilidade de se tratarem (e curarem?) doenças como leucemias, mal de Parkinson, Alzheimer, a par de se poderem desenvolver órgãos que poderão ser utilizados em transplantes, é uma perspectiva alentadora no sentido de melhorar a qualidade, e alongar o tempo de vida de muitas pessoas.

O poder de decisão quanto ao destino desses pré-embriões é questão também importante, parecendo-nos apropriado que ele deva, ser de seus "pais". Esta não é uma "questão menor", pois está em jogo a autonomia dos "doadores de células" embora ela deva vir depois da discussão conceitual de "a partir de quando se respeite um conjunto de células como vida humana".

Concluindo, queremos que esteja transparente que não é nossa pretensão, com as reflexões expostas, ofender os juízos sobre valores de pessoas, grupos étnicos ou religiões. Muito menos de criar normas coerentes com nossas posições. Nem poderíamos.

Os progressos científicos serão aceitos ou recusados segundo os já mencionados fatores culturais, e/ou religiosos. De forma tão democrática quanto possível. Mas também entendemos ser nosso papel, na bioética, o de expor e defender posições que consideramos importantes para a vida e saúde humana.

Marco Segre é professor do Departamento de Medicina Legal, Ética Médica, Medicina Social e do Trabalho da FMSUP, membro da CONEP (Comissão Nacional de Ética em Pesquisa), membro de CoBi (Comissão de Bioética do HC/FMUSP) e presidente da Sociedade de Bioética de São Paulo (S.B.S.P).

\section{Terapia celular em cardiologia Luís Henrique Wolff Gowdak}

No processo de reparação tecidual, como o que ocorre após o infarto agudo do miocárdio, diferentes tipos celulares (macrófagos/monócitos, fibroblastos, neutrófilos e células endoteliais) 
relacionados à cicatrização e remodelação tecidual são normalmente recrutados para a região afetada por mecanismos específicos envolvendo citocinas, alterações na matriz extracelular e proteínas de adesão. O transplante celular, técnica desenvolvida exeprimentalmente em passado recente e já testada clinicamente, pode vir a ser uma opção terapêutica visando limitar a perda miocitária pós-isquêmica e assim reduzir, ou até prevenir o aparecimento de insuficiência cardíaca.

\section{Transplante de mioblastos}

Miócitos adultos mantidos em cultura não se multiplicam, sugerindo que nessas células diferenciadas há uma resistência ao reinício do ciclo celular, o que limita a aplicação clínica desse tipo de estratégia. O potencial terapêutico de outro tipo celular, a célula muscular esquelética precursora (mioblasto) autóloga vem sendo explorado clinicamente.

Isto porque, diferentemente das células miocárdicas adultas e à semelhança dos fibroblastos cardíacos, as células musculares esqueléticas se dividem e são capazes de regeneração. Dorfman e colaboradores observaram que mioblastos implantados em miocárdio isquêmico de ratos podem sofrer um processo de diferenciação celular, transformando-se em fibras musculares estriadas.

Experimentalmente, Chiu e colaboradores transplantaram mioblastos em modelo de infarto do miocárdico por crioinjúria em cães. A análise histológica revelou a presença, nos sítios de implante, de tecido muscular semelhante ao cardíaco, incluindo a visualização de discos intercalares. Em outro modelo de infarto por ligação da artéria coronária em ratos, Scorsin e colaboradores estudaram o efeito do transplante de mioblastos esqueléticos. Ainda que no seguimento a função ventricular tenha melhorado, não foram detectadas gap junctions nas membranas das células esqueléticas, indicando prejuízo no acoplamento eletromecânico.

Clinicamente, o transplante de mioblastos teve início com o grupo de Menasché e colaboradores após o implante bem sucedido em um paciente de 72 anos, portador de insuficiência cardíaca avançada. Previamente ao transplante, a cicatriz miocárdica foi caracterizada como irreversivelmente acinética na ausência de viabilidade. Cerca de 5 meses após o transplante celular, a parede acinética tornou-se contrátil e metabolicamente ativa, do que resultou aumento na fração de ejeção do ventrículo esquerdo e melhora na classe funcional do paciente.

Uma das maiores limitações ao transplante de mioblastos é o seu grande potencial arritmogênico. Isto decorre pois a aparente inabilidade dessas células de transdiferenciação em cardiomiócitos e de formação de um sincício cardíaco com as células vizinhas nativas pode criar um substrato para arritmias ventriculares por reentrada.

Recentemente, o reconhecimento de células tronco com capacidade de diferenciação e neoformação tecidual levou à inclusão dessas células como participantes no complexo processo de reparação/regeneração tecidual e abriu perspectivas de seu uso terapêutico.

\section{Células-tronco e progenitoras hematopoéticas}

Há pelo menos 50 anos, as células tronco hematopoéticas são as que estão melhor caracterizadas entre as células tronco estudadas, o que levou a sua utilização terapêutica, associada às células progenitoras, no transplante de medula óssea.

A plasticidade dessas células em adquirir características de outras linhagens celulares diferentes das células hematopoéticas foi descrita recentemente e sua potencial utilização terapêutica para a reconstrução tecidual está sendo amplamente investigada. As principais características que distinguem essas células de outros tipos celulares são a capacidade de autoregeneração e diferenciação em várias células especializadas, a possibilidade de mobilização a partir da medula óssea para a circulação e a capacidade de evoluir para a morte celular programada em circunstâncias específicas.

Orlic e colaboradores, em modelo de infarto agudo do miocárdio experimental, injetaram na área perilesional $2 \times 105$ células tronco hematopoéticas. A análise imunohistoquímica da região infartada identificou $53 \%$ de cardiomiócitos, $44 \%$ de células endoteliais e $49 \%$ de células musculares lisas como provenientes das células-tronco injetadas. A avaliação da função ventricular revelou um ganho médio de $30 \%$ em relação aos animais controle.

Autores como Isner, Asahara e Kocher igualmente mostraram que células endoteliais progenitoras (CEP) humanas mobilizadas com GSCF (granulocyte stimulating colony factor) ou 
cultivadas, quando injetadas na veia caudal de ratos atímicos (1x106 a 2x106 células) após a ligadura da artéria coronária esquerda acarretavam em diminuição da área de necrose em cerca de $30 \%$, além de aumento da vascularização e conseqüente preservação da função ventricular.

Modelos animais de isquemia miocárdica já demonstraram que células de origem medular têm a capacidade de implantação local na área lesada e se diferenciam em células musculares cardíacas e em células endoteliais formando novos vasos sangüíneos (neoangiogênese).

Evidência adicional da potencial aplicabilidade da terapia celular em doenças do coração vem da observação por Kocher e colaboradores de que, em modelo experimental de infarto por ligadura da artéria coronária, células-tronco hematopoéticas de adulto (humanas) retiradas da medula óssea são capazes de dar origem a células endoteliais vasculares quando transplantadas em ratos. A angiogênese resultante do transplante celular levou à prevenção da apoptose de cardiomiócitos, redução de remodelamento ventricular e melhoria da função cardíaca.

A melhor compreensão da importância fisiológica das células-tronco do adulto nos processos de reparação tecidual permitiu que se estudasse eventuais relações entre fatores de risco cardiovascular e/ou terapias mediamentosas e células-tronco. Neste sentido, Vasa e colaboradores mostraram que, em 15 pacientes com doença arterial coronária (DAC) documentada, o tratamento com $40 \mathrm{mg} /$ dia de atorvastatina por 4 semanas levou a um aumento de cerca de 3 vezes no número de células progenitoras endoteliais ao final do período de observação. A importância clínica deste achado ainda está para ser determinada. A relevância das células progenitoras endoteliais para o aparecimento de doença cardiovascular (DCV) começou a ser questionada recentemente, quando Hill e colaboradores estudando 45 homens sem história de DCV mas com diferentes fatores de risco, demonstraram uma forte correlação negativa entre o número de células progenitoras endoteliais circulantes e o escore de risco combinado de Framingham. Especulam os autores que a lesão endotelial (secundária à presença dos fatores de risco) na ausência de número suficiente e adequado de células progenitoras endoteliais circulantes possa favorecer a progressão da doença cardiovascular.

Apenas muito recentemente, os primeiros relatos de terapia celular em pacientes portadores de DAC começaram a ser publicados. Assmus e colaboradores transplantaram, por infusão intracoronária, células progenitoras derivadas de medula óssea $(n=9)$ ou de sangue periférico $(n=11)$ a pacientes vítimas de infarto agudo pós-reperfusão, dentro de 4,3+/-1,5 dias após o IAM. Durante o seguimento de 4 meses, os pacientes tratados apresentaram aumento da fração de ejeção de $V E$, melhor motilidade regional na zona do infarto, diminuição do volume sistólico final e aumento da reserva de fluxo coronário na artéria relacionada ao IAM. Não foram observados eventos adversos.

O uso de células derivadas da medula óssea do adulto para o tratamento de doença isquêmica grave do coração associada à insuficiência cardíaca foi proposto por Perin e colaboradores em trabalho conduzido em 14 pacientes. Os pacientes foram submetidos à injeção transendocárdica guiada por mapeamento eletromecânico em áreas viáveis, porém isquêmicas. Os autores mostraram que, em seguimento de 4 meses, houve melhora da classe funcional, redução significativa nos defeitos perfusionais avaliados por medicina nuclear e aumento da fração de ejeção de $20 \%$ para $29 \%$.

Stamm e colaboradores propuseram a utilização combinada de injeções intramiocárdicas de células-tronco derivadas da medula óssea com potencial de indução de angiogênese à cirurgia de revascularização miocárdica em 6 pacientes pós-IAM. Cerca de 1,5×106 células foram injetadas em cada paciente na borda da zona de infarto durante a cirurgia de RM. Após 3 a 9 meses de seguimento, todos os pacientes se encontravam vivos; aumento na motilidade global (em 4 dos 6 pacientes) e da perfusão da área de infarto (em 5 dos 6 pacientes) pôde ser documentada.

No Instituto do Coração (InCor) do Hospital das Clínicas, em São Paulo, Gowdak e colaboradores adotaram estratégia semelhante para o tratamento de pacientes com DAC grave e difusa, refratários ao tratamento clínico e não passíveis de revascularização cirúrgica completa pela extensão da doença. Em 10 pacientes, 13×107 células-tronco e progenitoras hematopoéticas autólogas foram injetadas, durante a cirurgia de revascularização, naquelas áreas de miocárdio previamente identificadas como viáveis e isquêmicas. Não houve eventos adversos relacionados ao procedimento. A análise da perfusão miocárdica nos segmentos injetados e não revascularizados apontou para a reversão da isquemia nesses segmentos e melhora contrátil. Ainda que não se possa excluir a contribuição dos enxertos realizados à distância para a melhora observada nos segmentos injetados, pode-se especular que o implante de células tenha contribuído via indução de angiogênese para a melhora perfusional e contrátil nessas áreas. 


\section{Considerações sobre o uso de células-tronco do adulto}

A aplicação do uso de células-tronco do adulto suscita diversas questões ainda em investigação. A seguir, listamos algumas considerações que acreditamos deverão ser respondidas com o avanço das pesquisas de remodelação e regeneração tecidual:

os mecanismos intrínseco, molecular e tecidual de manutenção do estado de quiescência e pluripotência das células-tronco do adulto não são conhecidos.

uma vez obtidas as células-tronco do adulto, discute-se como manter uma célula-tronco em seu estado quiescente e proliferativo por um período prolongado de tempo sem a influência de citocinas que transformem estas células. utilizar um conjunto de células que dariam suporte à proliferação e manutenção das células-tronco poderia ser mais vantajoso do que o uso de um único tipo de célula como as mesenquimais ou as células progenitoras. uso de células-tronco em sistemas biomiméticos pode possibilitar seu emprego em diferentes áreas na cardiologia: vasos biocompatíveis com maior viabilidade, bioengenharia muscular, etc.

aspectos como a identificação de qual tipo celular é o mais adequado para o efeito terapêutico desejado, a sobrevida das células transplantadas, vias ótimas de acesso ao miocárdio (endovascular ou cirúrgica) para o transplante celular e a definição do comportamento das células transplantadas em relação ao tecido nativo (acoplamento eletromecânico, contribuição funcional, alteração do remodelamento ventricular) são de capital relevância e devem ser considerados antes que a terapia celular possa ser rotineiramente empregada.

Luís Henrique Wolff Gowdak é ex-fellow Gene Therapy Unit, Laboratory of Cardiovascular Science, National Institutes of Health, Estados Unidos - Doutor em Cardiologia pela Faculdade de Medicina da USP - Médico-Assistente do Laboratório de Genética e Cardiologia Molecular e da Unidade Clínica de Coronariopatias Crônicas do Instituto do Coração (InCor) do Hospital das Clínicas da Faculdade de Medicina da USP.

\section{Células-Tronco e Câncer: vida e morte com uma origem comum?}

\section{Flávio Henrique Paraguassú-Braga e Adriana Bonomo}

As células-tronco estão presentes desde a vida embrionária até a vida adulta, e provavelmente até nossa morte. São elas as responsáveis pela formação do embrião e também pela manutenção dos tecidos na vida adulta. No início da vida embrionária, as células-tronco são virtualmente totipotentes, ou seja, apresentam capacidade de gerar quaisquer tecidos do organismo. Contudo, após a formação do embrião propriamente dito, diversos tecidos mantêm células-tronco que participam da fisiologia normal (e da patologia também) na vida adulta.

Conceitualmente, as células-tronco apresentam duas características fundamentais: 1) autorenovação ilimitada, por exemplo, a capacidade de multiplicar-se gerando células iguais à célulaoriginal durante toda a vida, e ; 2) pluripotência, como, por exemplo, a capacidade de gerar diferentes tipos celulares.

Apesar de existirem em baixa freqüência, seus números são suficientes para manter os tecidos que necessitam de renovação constante. Em alguns sistemas onde são bem caracterizadas, sua freqüência é estimada em 1 para cada 100.000 células totais daquele tecido. As células-tronco, à medida que se dividem, geram progenitores comprometidos, com uma capacidade de proliferação ainda mais limitada e um restrito potencial de diferenciação devido ao comprometimento com uma linhagem celular única. A partir deste ponto, esta célula já comprometida chamada precursor, já possui morfologia definida e seu potencial proliferativo é limitado ou mesmo nulo.

As células-tronco mais bem conhecidas, são as células-tronco do tecido hematopoiético, identificadas por Till e McCulock há mais de 40 anos. Recentemente, outros tecidos tiveram suas 
células-tronco identificadas como do sistema nervoso, fígado, pele e mucosas, intestinos e até mesmo coração.

O tecido hematopoiético se desenvolve na vida adulta de maneira hierarquizada. A Célula Tronco Hematopoiética (CTH) é multipotente e imortal, ou seja, apresenta potencial para diferenciar-se em qualquer célula hematopoiética e pode ao longo prazo gerar outras células-tronco. As CTH originam as Células Progenitoras Hematopoiéticas $(\mathrm{CPrH})$, que são células determinadas às diferentes linhagens hematopoiéticas, com alto potencial e taxa de proliferação. Essas por sua vez originam as Células Precursoras Hematopoiéticas (CPH) e Células Maduras (CM) do sangue e de outros órgãos, sendo totalmente diferenciadas morfo e funcionalmente.

No sistema hematopoiético, o papel das células-tronco é muito claro. Por hora, produzimos 1$5 \times 109$ células vermelhas e 1-5×109 células brancas. A produção desses tipos celulares, os três principais dentre outros elementos celulares do sangue, é constante e necessária já que a meia vida das células sanguíneas é muito curta, sendo em alguns casos da ordem de horas. A homeostasia do tecido sanguíneo é rigidamente regulada e qualquer alteração nessa dinâmica entre morte e produção celular resulta em algum processo patológico. Por exemplo, quando não há produção de células novas ou há morte em excesso de células diferenciadas, temos aplasias ou anemias. Por outro lado, quando temos uma produção exacerbada de novas células ou uma resistência maior de células diferenciadas à morte, temos neoplasias ou cânceres. Esses desequilíbrios também ocorrem em tecidos de outra origem como tecido nervoso, conjuntivos (osso, cartilagem) e tecidos epidermais (pele, intestinos, estômago, e glândulas).

\section{Câncer: "desdiferenciação" ou doença da célula-tronco?}

Classicamente, aprendemos que um câncer é uma célula imortal, ou que é uma célula que apresenta características embrionárias pois, como muitos tecidos embrionários, é uma célula que não apresenta um estado de diferenciação claro e, ao mesmo tempo, apresenta uma notória capacidade de proliferação. Esse conceito evoluiu para "o câncer é uma célula incapaz de diferenciar-se" refletindo o antigo conceito de células com características embrionárias no indivíduo adulto.

Atualmente, o conceito de um câncer como uma doença de células que não se diferenciaram ou que perderam seus mecanismos de controle de proliferação evoluiu para "o câncer é uma doença da célula-tronco".

Inicialmente, aprendemos que um câncer tem uma capacidade de proliferação ilimitada. Contudo, o que parece é que um tumor, seja um tumor sólido, seja uma leucemia (câncer das células do sangue), se comporta como uma unidade tecidual, com uma dinâmica de renovação que envolve proliferação e morte de uma população celular heterogênea. Esta heterogeneidade aparece principalmente em relação ao potencial proliferativo dessa população.

\section{Leucemias: um modelo enriquecedor}

Se pensarmos numa leucemia da maneira clássica descrita no item anterior, na qual todas as células são capazes de proliferação ilimitada, qualquer célula purificada de uma população de células leucêmicas seria capaz de proliferar indefinidamente tanto in vitro quanto in vivo. A partir da década de 60, pesquisadores como Bruce e Gaag, Wodinsky, entre outros, e posteriormente Park e seus colaboradors no início dos anos 70 , apresentaram as primeiras evidências de que isso não era verdade. Esses últimos evidenciaram que apenas 1 a $4 \%$ de células leucêmicas de camundongos eram capazes de formar colônias ${ }^{\underline{1}}$ quando transferidas para outro animal geneticamente idêntico. 
Figura 2. A origem da célula tronco leucêmica (CTL)

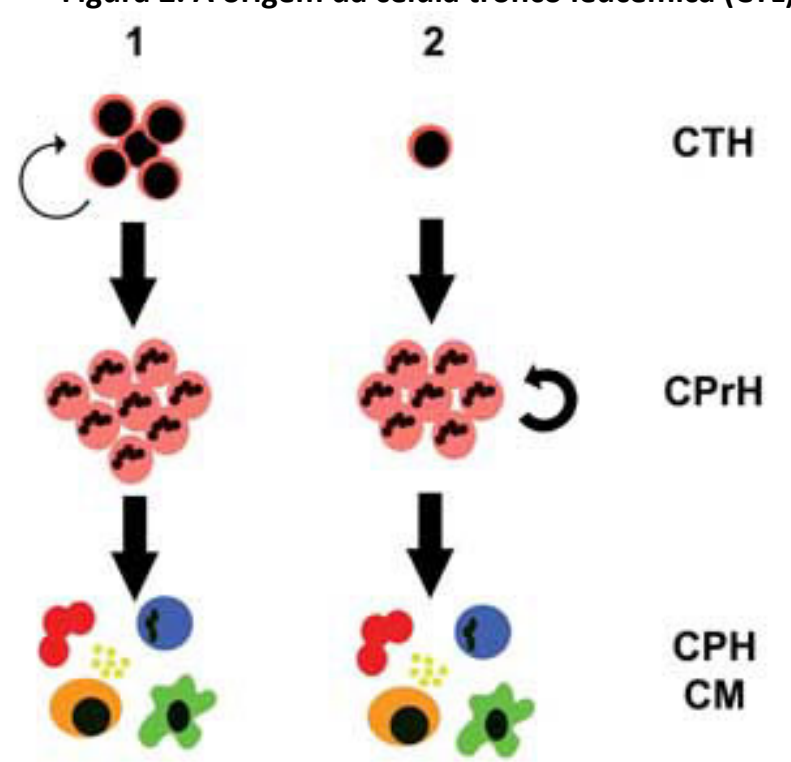

Uma determinada leucemia pode ser vista como um tecido hematopoiético anormal iniciada por CTLs que sofrem uma desenvolvimento aberrante e pouco controlado. As CTLs podem ser CTHs que se tornaram leucêmicas como resultado de alterações acumuladas (1) ou progenitores mais

comprometidos que readquiriram capacidade de autorenovação da célula tronco (2).

Mais recentemente, isso foi demonstrado para leucemias humanas, por Blair e colaboradores e Bonnet e Dick. Utilizando camundongos imunodeficientes (animais desprovidos de sistema imune e portanto incapazes de rejeitar quaisquer células), mostraram que apenas uma fração de células leucêmicas de leucemia mielóide aguda (LMA) era capaz de gerar doença (por exemplo, proliferar). Essa população correspondia à fração com características de células-tronco, similares às célulastronco hematopoiéticas ${ }^{\underline{2}}$. Mais do que isso, mostraram que as outras populações, que não apresentam as características da célula-tronco, não eram capazes de gerar a doença e que a freqüência das células capazes de gerar doença era extremamente baixa, variando de 0,2 a 1\% da população total de células doentes.

Muitas leucemias, e alguns tumores sólidos também, apresentam anormalidades genéticas que, por sua vez, caracterizam a patologia ou, por outras vezes, correlacionam com o prognóstico da doença. De qualquer forma, tais anormalidades nos gens, que envolvem deleções ou translocações de cromossomos ou suas partes servem para identificar essas células tumorais e talvez sua origem. Ainda na leucemia mielóide aguda (LMA), a anormalidade cromossômica mais comum é a translocação de parte do cromossomo 8 que se justapõe ao cromossomo 21, identificado como um transcrito quimérico chamado AML1-ETO. Em pacientes em remissão da LMA, o transcrito AML1-ETO, pode ser encontrado nas células-tronco hematopoéticas normais, e as mesmas células quando isoladas são capazes de gerar células sanguíneas normais, assim como não foram capazes de gerar leucemia. O que indica que a translocação ocorreu nas células-tronco, mas alguma ou algumas alterações a posteriori foram necessárias para a transformação maligna. Isto é verdade em outros tipos de leucemias, como na leucemia mielóide crônica, onde um produto de translocação gênica (específico dessa leucemia) aparece não só nas células leucêmicas, mas também em células hematopoiéticas normais e também em outros tipos celulares como no endotélio. Este último tem a mesma origem embriológica que as células do sangue, indicando que a translocação ocorreu numa célula tronco embrionária, que originou tanto o tecido hematopoiético que se malignizou quanto os vasos sanguíneos, que são normais. 
Figura 3

1)

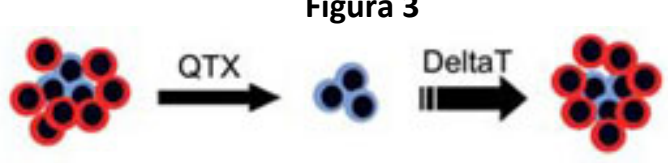

2)

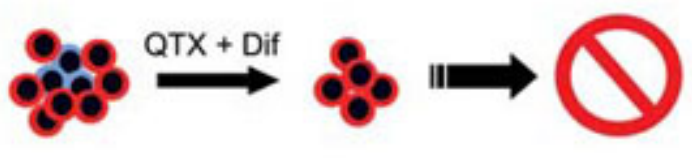

3)

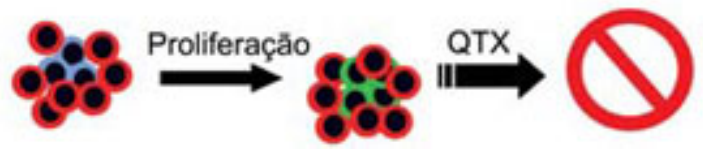

A manutenção de um tecido tumoral baseado em uma célula tronco tumoral leva a complicações biológicas no curso da doença. A maioria dos métodos de tratamento quimioterápicos têm como alvo células em proliferação (células vermelhas). As células tronco (células azuis) são pouco

freqüentes e quiescentes portanto resistentes a esses tratamentos. A longo prazo elas voltam a compor um novo tecido tumoral (1). Baseados nos estudos da biologia da célula tronco, a diferenciação das células tronco tumoral, a tornaria sensível à quimioterapia (2). O mesmo aconteceria ao estimular a proliferação da célula tronco tumoral (células verdes - 3).

Acredita-se que a transformação maligna se dá pelo acúmulo de mutações, que podem ser acompanhadas ou não de aberrações cariotípicas (anomalias genéticas citadas acima). A probabilidade das alterações ocorrerem se relaciona ao potencial proliferativo da população em questão. Por isso, essa transformação maligna pode não ocorrer na célula-tronco, que é uma célula com freqüência quiescente, mas pode ocorrer em seus progenitores, que são células que passam por vários ciclos de divisão para expansão da população periférica. De fato, podemos até propor que a baixa freqüência das células tronco adultas somado a sua quiescência a protegem de mecanismos de transformação maligna.

\section{Câncer de mama}

Assim como o tecido hematopoiético, o tecido mamário possui células-tronco capazes de gerar diversos tipos celulares.

Se nos lembrarmos da função da mama, que é a produção de leite durante o período de gestação e lactação, podemos dizer que a mama por excelência é um tecido displásico. Responde à gestação com hipertrofia, proliferação e especialização de células epiteliais que produzem leite, regredindo após a lactação. O tecido mamário é notoriamente formado pelo desenvolvimento de ramificações, botões mioepiteliais que adentram o tecido adiposo subjacente quando em desenvolvimento. Ao final das terminações existe um sítio com células tidas como células-tronco da mama: as mesmas geram células progenitoras, que dão origem a uma camada externa, mioepitelial, e outra população que forma uma camada interna, que se diferenciam para formar a luz do tubo em desenvolvimento.

Analogamente às leucemias, o câncer de mama parece depender de uma célula-tronco para se manter, porém um modelo baseado em células-tronco para câncer de mama surgiu apenas no ano passado .

De maneira similar ao realizado com as leucemias do sistema hematopoiético, Al-Hajj e colaboradores separaram diversas subpopulações de células de câncer de mama em função da presença de marcadores moleculares específicos e injetaram em camundongos imunoincompetentes. Das várias subpopulações, apenas uma foi capaz de gerar tumores nesses camundongos, com toda a heterogeneidade celular presente na população original. Esses dados mostram que também, neste caso, há uma célula-tronco cancerosa, e que apenas esta é tumorigênica.

Implicações 
A pesquisa e caracterização de células-tronco tumorais é crucial no entendimento do câncer enquanto doença. Muitas das informações que obtemos e derivamos para o diagnóstico, prognóstico e tratamento dessa patologia deriva de populações heterogêneas, com diferentes graus de maturação. Cada vez mais temos a noção de que o câncer é um tecido ou uma unidade tecidual, que se desenvolve com suas próprias células-tronco, assumindo um crescimento que não corresponde ao padrão do organismo. Neste momento, cada vez mais se torna urgente a caracterização das células-tronco tumorais para otimização das metodologias de diagnóstico e avaliação de prognóstico. Um melhor ou pior prognóstico está relacionado à freqüência de célulastronco em um tumor. A conseqüência direta é a necessidade do desenvolvimento de estratégias terapêuticas que consigam atuar sobre as células-tronco, e não apenas sobre as células com alto potencial proliferativo, porém com baixa capacidade de autorenovação. Essas estratégias deverão considerar a especificidade dos marcadores das células-tronco, sua baixa freqüência e baixa taxa de proliferação que a torna resistente aos quimioterápicos ciclo-dependentes. Quem sabe, num futuro próximo, novas formas de regular o crescimento e manutenção da célula-tronco, estarão disponíveis para o tratamento das doenças malignas.

\section{Referências:}

1. A formação de colônias se refere à capacidade proliferativa das células, sendo somente formada por células com alto potencial proliferativo. [voltar]2. As células tronco hematopiéticas são bem caracterizadas quanto às moléculas que expressam em sua superfície. Estas características, que chamamos de fenótipo, permitem que sejam identificadas e purificadas a partir de uma população heterogênea. [voltar]

Flávio Henrique Paraguassú-Braga, trabalha no Banco de Sangue de Cordão Umbilical e Placentário do Instituto Nacional de Câncer, do Rio de Janeiro. Adriana Bonomo é pesquisadora da Divisão de Medicina Experimental do CPQ do mesmo instituto e é também professora do Instituto de Microbiologia, da Universidade Federal do Rio de Janeiro.

\section{Aplicações terapêuticas das células-tronco: perspectivas e desafios}

Claudio L. Lottenberg

\section{e Carlos A. Moreira-Filho}

As células-tronco (CT) são células primordiais indiferenciadas, encontradas em tecidos embrionários (CTE) e também em tecidos adultos (CTA) como o hematopoético, muscular, epitelial, nervoso e hepático. O potencial ilimitado de auto-renovação e a capacidade de originar linhagens celulares com diferentes funções impulsionaram pesquisas sobre as aplicações terapêuticas dessas células. Os principais alvos têm sido as doenças crônicas, (doenças cardiovasculares e neurodegenerativas, nefropatias, diabetes tipo 1) o acidente vascular cerebral, as doenças hematológicas, as imunodeficiências, e traumas da medula espinhal, onde o objetivo mais imediato é reparar ou reconstituir o tecido afetado pela doença.

As primeiras aplicações terapêuticas de CT ocorreram com o uso de células multipotentes derivadas de tecidos adultos, tanto em transplantes autólogos como em alogênicos, enquanto o uso de CTE ainda está limitado aos experimentos com modelos animais. A maior experiência está no uso de células-tronco derivadas do tecido hematopoético, as CTH, que já são largamente empregadas como alternativa ao transplante de medula óssea no tratamento de leucemia aguda e leucemia mielóide crônica com excelentes resultados ${ }^{\underline{1}}$.

\section{Células do sangue de cordão umbilical}

No Brasil são feitos anualmente cerca de 2,5 transplantes de medula por milhão de habitantes contra uma média de 7 a 10 nos países desenvolvidos. As limitações são o custo do procedimento e a baixa disponibilidade de doadores compatíveis. A conseqüência para o paciente é um tempo de espera em torno de um ano, infelizmente longo demais em muitos casos. Uma alternativa para aumentar a disponibilidade de doadores, e reduzir o custo do transplante, é o uso de sangue de cordão umbilical (SCU), rico em células-tronco e que pode ser usado para reconstituição hematopoética. As células de SCU são menos imunorreativas que as da medula óssea, permitindo o uso em transplantes não-aparentados idênticos ou parcialmente idênticos com menos complicações. As células de SCU podem ser criopreservadas e bancos públicos dessas células 
existem em vários países, destacando-se a iniciativa pan-européia Eurocord2. Em 2003 esses bancos já dispunham de 130.000 unidades de SCU disponíveis para transplante e 3.000 transplantes já haviam sido feitos desde 1998, com alta taxa de sucesso ${ }^{\underline{2}}$.

O banco público possui importantes vantagens sobre o congelamento privado de SCU. A mais importante é que o transplante autólogo (com células do próprio paciente) tem resultado pior do que o alogênico (com células de um doador, aparentado ou não) em casos de leucemia, imunodeficiências e anemia aplástica ${ }^{3}$. Além disso, a probabilidade de que uma criança vá precisar de suas próprias células é, segundo a maioria dos estudos, muito baixa (1:100. 000), não justificando os custos do depósito para uso próprio.

Presentemente, única desvantagem do uso de SCU é o que número de CTH por cordão varia conforme a doadora e as condições de coleta, limitando o transplante a pacientes na faixa de 50 $60 \mathrm{~kg}$ de peso. Essa limitação deverá ser superada brevemente: técnicas de expansão ex-vivo das CTH derivadas de cordão estão sendo desenvolvidas por vários grupos de pesquisa, entre os quais o do IEP Albert Einstein, o que aumentará o alcance dos bancos de SCU.

O desafio brasileiro é estabelecer um banco público de SCU. A meta definida pelo projeto Brasil Cord ${ }^{4}$, de 1999, previa a coleta de 12.000 unidades de SCU em 3 anos (com o que estaria coberta diversidade genética da população brasileira) em 4 a 8 centros de processamento no país. Estudos de viabilidade técnica e econômica dessa rede foram revisados em 2002 por um grupo multi-institucional reunido no IEP Albert Eisntein.

A busca de células compatíveis de medula óssea com auxílio dos bancos internacionais é de USD 40.000,00 por paciente4, e o sistema público de saúde deve gastar USD 2 milhões por ano apenas nesse tipo de busca, considerando-se a meta de 50 transplantes/ano autorizados nessas condições. Isso, obviamente, não inclui o custo do transplante. Complicações derivadas da menor identidade genética entre doador e receptor aumentam o risco de complicações e o custo final do procedimento. A implantação completa do Brasil Cord (equipamento dos centros, treinamento das equipes e custeio das operações de coleta) não superaria USD 10 milhões em 5 anos e permitiria a realização de 190 transplantes/ano, com economia de USD 7.5 milhões/ ano de gastos no exterior. Além da vantagem econômica, estão a garantia da disponibilidade das células, a geração de tecnologia no país e a abertura para a pesquisa de outros usos terapêuticos das CTH derivadas de cordão, o que, novamente, passa pelo banco público.

\section{Aplicações em cardiologia}

Em cardiologia as CTH autólogas (coletadas da medula óssea do próprio paciente) são ainda as células de escolha para uso em procedimentos que visam a regenerar o músculo cardíaco afetado por infarto. Insuficiências cardíacas causadas por perda ou disfunção de células musculares no coração atingem cerca de 4.8 milhões de pessoas nos EUA, com cerca de 400.000 novos casos por ano, e uma taxa de mortalidade superior a $50 \%$ dentro dos cinco primeiros anos após o diagnóstico inicial (NIH report, 2001).

O emprego de CT pode atenuar danos causados ao coração em decorrência de hipertensão, insuficiência crônica, doença da artéria coronária ou ataque cardíaco, contribuindo para uma redução da taxa de morbidade. Estudos pré-clínicos com modelos animais de infarto agudo do miocárdio constataram a regeneração de músculo e a formação de neo-vasos em área infartada, após transplantes de CT alogênicos ${ }^{5}$. Em seres humanos, esses resultados foram confirmados em estudos de fase I com CTH multipotentes da medula óssea e mioblastos esqueléticos ${ }^{6,7}$, abrindo a possibilidade do uso de células autólogas nesses procedimentos.

Presentemente, investiga-se com qual população, ou populações de CT adultas, se obtêm os melhores resultados em termos de reparo muscular e revascularização, havendo grande interesse nos progenitores endoteliais (angioblastos) e nas células mesenquimais da medula óssea. Nessa linha, o IEP Albert Einstein e o Depto. de Cardiologia do Hospital Albert Einstein desenvolvem um projeto para o uso de CT autólogas no tratamento de voluntários com cardiomiopatia isquêmica, com os primeiros transplantes previstos para o final de 2004.

\section{Aplicações em neurologia}

Entre as primeiras aplicações da terapia celular em neurologia está o tratamento da esclerose múltipla, uma doença inflamatória crônica do sistema nervoso central, de natureza autoimune, com 
déficit neurológico progressivo. O tratamento convencional emprega drogas imunossupressoras, mas há casos refratários onde a terapia celular com CTH aparece como alternativa. O procedimento consiste em intensa imunossupressão por quimioterapia e /ou radioterapia, seguida da reconstituição do sistema imune com CTH autólogas ou alogênicas. Ou seja, procura-se eliminar as células do sistema imune do paciente que estão agredindo seu sistema nervoso e substituí-las por novas células derivadas das CTH. No hospital Albert Einstein está em execução um estudo piloto onde as CTH do paciente com esclerose múltipla refratária são mobilizadas para a circulação periférica com o uso de determinadas drogas, coletadas e congeladas. A seguir o paciente submetese à imunossupressão com quimioterapia e, depois, à reconstituição hematopoiética, feita com suas próprias CTH que haviam sido congeladas. Protocolos de pesquisa desse tipo estão em execução em diversas instituições no mundo com resultados satisfatórios: cerca de $70 \%$ dos pacientes apresentam melhora ou estabilização do quadro.

O próximo desafio nessa área são as doenças cérebro-vasculares. O interesse mais imediato é o emprego de CT na redução de morbidade após o acidente vascular cerebral isquêmico (AVCI), uma doença com altas taxas de mortalidade e morbidade no Brasil. Em ratos já está demonstrado que a infusão endovenosa de células estromais da medula óssea induz angiogênese na zona periisquêmica pós $\mathrm{AVCl}$. Mais ainda, em camundongos foi verificado o aparecimento de células endotelias e de células expressando o marcador neuronal Neu-N após transferência de células de

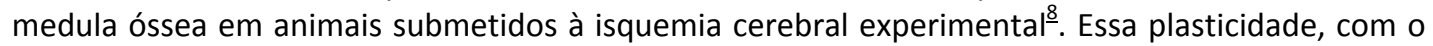
aparecimento conjunto de precursores neuronais e endoteliais na área isquêmica, abre grandes esperanças para o uso de CT em terapias celulares neuro-restaurativas. Esse mesmo caminho deverá ser trilhado para o uso de CT autólogas na redução de morbidade em casos de lesão da medula espinhal. Todas essas pesquisas envolvem, preliminarmente, a identificação in vitro dos fatores de diferenciação e de direcionamento das CT ao tecido alvo do tratamento.

\section{Perspectivas futuras}

O potencial terapêutico das CT vem se afirmando como altamente promissor. A caracterização cada vez mais detalhada de novos tipos de CT em tecidos maduros e a exploração de fontes alternativas de $\mathrm{CT}$, como o sangue de cordão umbilical, é uma linha de pesquisa relevante no rumo da medicina regenerativa. Mas não é o único caminho a ser trilhado nesse rumo. De grande interesse é também o estudo das CTE $\underline{\text {. }}$ O uso de CTE está na agenda dos governos em muitos países, com fortes pressões a favor e contra o uso de blastocistos humanos oriundos de fertilização in vitro como fonte dessas células (12). Muitos países, como os EUA, liberaram os estudos com as linhagens de CTE já existentes (cerca de 78), mas proibiram temporariamente a obtenção de novas linhagens. Outros, como o Reino Unido e Israel, têm postura liberal quanto ao uso experimental de embriões. No Brasil, no momento em que este artigo é escrito, a situação ainda está indefinida. É absolutamente certo que a pesquisa com CTE pode abreviar o tempo necessário para se dominar os caminhos que levam as CT a se transformar em células do sangue, dos músculos ou do sistema nervoso. Existe a possibilidade de que, para algumas aplicações terapêuticas, essas células venham a se mostrar imprescindíveis. A comunidade científica não pode arbitrar esse debate, onde se joga uma parte do futuro de toda a humanidade, mas deve dele participar ativamente porque a difusão do conhecimento é indissociável da atividade de pesquisa.

Claudio L. Lottenberg é pesquisador do Hospital Israelita Albert Einstein. Carlos A. MoreiraFilho é pesquisador do Instituto de Ensino e Pesquisa Albert Einstein e do Depto. de Imunologia do Instituto de Ciências Biomédicas da USP 